UNIVERSIDADE DE SÃO PAULO

FACULDADE DE ECONOMIA, ADMINISTRAÇÃO E CONTABILIDADE DEPARTAMENTO DE CONTABILIDADE E ATUÁRIA PROGRAMA DE PÓS-GRADUAÇÃO EM CIÊNCIAS CONTÁBEIS

\title{
ALTERAÇÕES NO PATRIMÔNIO LÍQUIDO A PARTIR DE 2010 E A PERCEPÇÃO DOS DOCENTES DE CONTABILIDADE
}

\author{
Alexandre Gonzales
}

Orientador: Prof. Dr. Ariovaldo dos Santos

SÃO PAULO 
Prof. Dr. João Grandino Rodas

Reitor da Universidade de São Paulo

Prof. Dr. Reinaldo Guerreiro

Diretor da Faculdade de Economia, Administração e Contabilidade

Prof. Dr. Edgard Bruno CornacchioneJúnior

Chefe do Departamento de Contabilidade e Atuária

Profa. Dra. Silvia Pereira de Castro Casa Nova

Coordenadora do Programa de Pós-Graduação em Controladoria e Contabilidade 


\section{ALTERAÇÕES NO PATRIMÔNIO LÍQUIDO A PARTIR DE 2010 E A PERCEPÇÃO DOS DOCENTES DE CONTABILIDADE}

Tese apresentada ao Departamento de Contabilidade e Atuária da Faculdade de Economia, Administração e Contabilidade da Universidade de São Paulo como requisito para a obtenção do título de Doutor em Ciências.

Orientador: Prof. Dr. Ariovaldo dos Santos.

\section{Versão corrigida}

(versão original disponível na Faculdade de Economia, Administração e Contabilidade)

\section{SÃO PAULO}


Autorizo a reprodução e a divulgação total ou parcial deste trabalho, por qualquer meio convencional ou eletrônico, para fins de estudo e pesquisa, desde que citada a fonte.

FICHA CATALOGRÁFICA

Elaborada pela Seção de Processamento Técnico do SBD/FEA/USP

Gonzales, Alexandre

Alterações no patrimônio líquido a partir de 2010 e a percepção

dos docentes de contabilidade / Alexandre Gonzales. - São Paulo,

2013.

$188 \mathrm{p}$.

Tese (Doutorado) - Universidade de São Paulo, 2013.

Orientador: Ariovaldo dos Santos.

1. Contabilidade societária 2. Contabilidade 3. Patrimônio liquido

4. Demonstração financeira I. Universidade de São Paulo. Faculdade de Economia, Administração e Contabilidade. II. Título.

CDD - 657.92 
Ao Pedro Henrique e à Ana Beatriz que mesmo sem perceber foram fontes de inspiração e contribuíram para este trabalho. 

Agradeço aos meus amigos do curso de doutorado que fizeram com que essa jornada ficasse menos árdua, em especial: Carlão, Alex, Ivan, Ricardo, Pati, Cris, Feitosa, Aziz, Rafinha, Daniel, Esmael, Claudia, Ana Paula, Eric, Bel, Edgard.

Agradeço aos meus amigos que me incentivaram desde antes de conseguir entrar no programa, com destaque para Camila por ter me acompanhado desde a época em que estudávamos para as provas e Bifi que sempre me incentivou.

Agradeço aos amigos professores da PUC/SP que torceram por mim. Impossível esquecer a Edilene que sempre se mostrou pronta para ajudar nos períodos de necessidade.

Agradeço à minha família por ter me tolerado nesse período. Em especial, meu pai Roberto por entender as minhas necessidades, minha mãe Maria pela ajuda, e minha irmã Audrey pela compreensão.

Agradeço aos professores do programa por terem forjado uma pessoa diferente. Destaque para o Professor Corrar pela sua cobrança, Professor Eliseu pela inspiração. Lembro-me que na semana de integração o Prof. Edgard dizia que um dos objetivos do programa era o de mudar os seus alunos. Professor Edgard, vocês conseguiram. O Alexandre que sai não é o Alexandre que entrou.

Agradeço à BM\&FBovespa pelo fornecimento das informações das companhias abertas.

Agradeço ao Guia do Estudante da Editora Abril por fornecer informações necessárias à realização do questionário com os professores, na figura da Emanuele e de seu diretor de redação Fabio Volpe.

Agradeço à revista Exame Melhores e Maiores por fornecer os dados necessários para o levantamento das informações relacionadas às companhias abertas.

Agradeço à Iara Augusta de Souza pelo auxílio na obtenção das demonstrações contábeis das companhias abertas.

Por último, mas em hipótese alguma menos importante, agradeço ao Ari. Conheci o Ari no dia da entrevista durante o processo seletivo. Por acaso acabei sendo seu monitor durante o primeiro semestre, e continuei não por acaso no segundo. Ele se tornou meu orientador, mas não antes de perguntar se era isso mesmo que eu queria, o que confesso me fez pensar duas vezes. Tenho dúvida se devo agradecer mais a ele por ser meu orientador ou por ter assistido suas aulas. Professor linha dura, direto e brilhante. Sempre será para mim uma referência a ser seguida. Não poderia ter tido orientador melhor. 

Nenhum homem pode atravessar o mesmo rio duas vezes, porque nem o homem nem o rio são os mesmos.

Heráclito 



\section{RESUMO}

A contabilidade nacional tem passado por mudanças no sentido de convergir suas normas às internacionais. O início dessas mudanças se deu, em 2008, por força da Lei no 11.638/2007, e foi completado em 2010, por força da Medida Provisória no 449/2008, convertida posteriormente na Lei n- $11.941 / 2009$. Dentre as mudanças que atingiram a contabilidade algumas estão relacionadas ao patrimônio líquido das empresas, por meio da criação de contas ou de reclassificação de valores do patrimônio líquido e de outros elementos das demonstrações contábeis. O patrimônio líquido deve ser entendido como um valor residual, ativo menos passivo, e é componente importante no balanço patrimonial das empresas. Partiu-se da plataforma teórica da Teoria Contratual da Firma, pela qual os agentes que interagem com as empresas se utilizam da contabilidade para avaliar o que entregam e o que recebem de retorno dessas empresas. O patrimônio líquido assume papel importante nessa relação, assim como as alterações relacionadas a ele. O presente trabalho buscou identificar a extensão das alterações no patrimônio líquido de companhias abertas em 2010, primeiro ano no qual todas as alterações propostas haviam sido introduzidas. A pesquisa foi efetivada com base em demonstrações contábeis de companhias abertas, as quais foram classificadas em setores. Após a referida classificação, buscou-se igualmente captar a percepção dos docentes de contabilidade sobre essas alterações por meio de questionários. Como resultado, identificou-se que as alterações promovidas no patrimônio líquido das empresas foram significativas em parte dos casos analisados, e que não afetaram empresas de segmentos distintos de forma homogênea. Verificou-se também que, embora exista consenso entre docentes de contabilidade sobre questões como a importância do patrimônio líquido e de sua composição para os usuários da contabilidade, não houve consenso quanto à extensão dos impactos no patrimônio líquido das empresas, decorrentes da alteração normativa contábil recente. 



\begin{abstract}
The national accounting has undergone changes in order to converge its standards with international standards. The beginning of these changes was in 2008 by law $n^{\circ} 11.638 / 07$, and was completed in 2010 under the Provisional Measure 449/08, converted later in law $n^{\circ}$ 11.941/09. Among the changes that affected accounting some are related to equity of companies through the creation of accounts, or by reclassification of values in equity and other elements previously classified elsewhere in the financial statements. The equity should be understood as a residual value, assets minus liabilities, and is an important component in the balance sheet of companies. Starting from the theoretical framework of the Contractual Theory of the Firm, by which agents that interact with the companies use accounting to assess what they deliver and what they receive in return from these companies. Equity plays an important role in this relationship, so as changes related to it. The present study sought to identify the extent of changes in equity of listed companies in the year 2010, the first year in which all proposed changes had been introduced. The research was done based on the financial statements of public companies, which were classified into sectors. Following this classification, also was sought to capture the perception of accounting teachers about these accounting changes through questionnaires. As a result it was found that the changes introduced in the equity of companies were significant in most cases analyzed, and that did not affect distinct segments companies evenly. Also was verified that although there is consensus among accounting teachers on issues such as the importance of equity and its composition for the users of accounting, there was no consensus about the extent of the impact on equity of companies arising from recent changes in accounting regulations.
\end{abstract}





\section{SUMÁRIO}

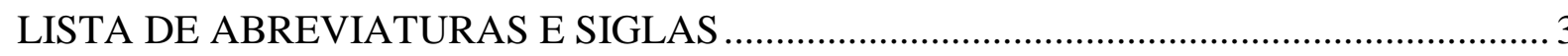

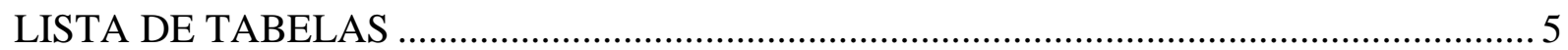

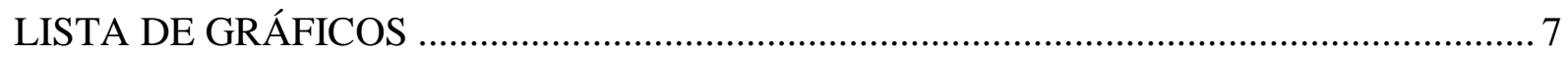

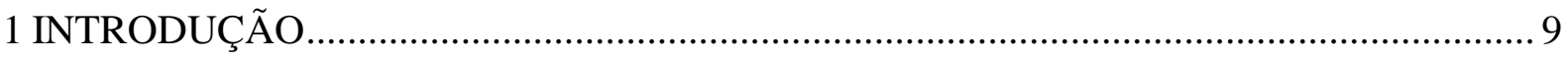

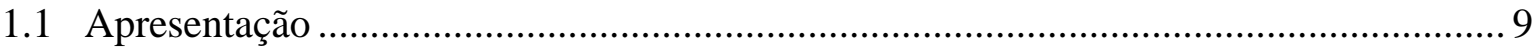

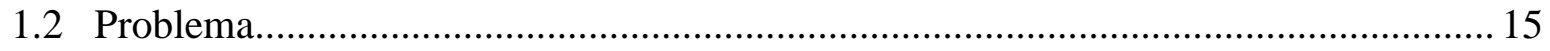

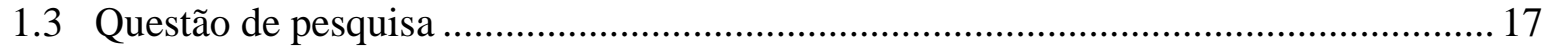

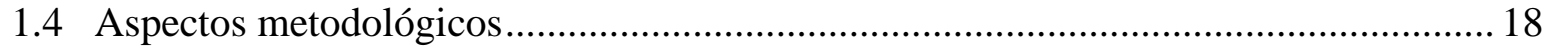

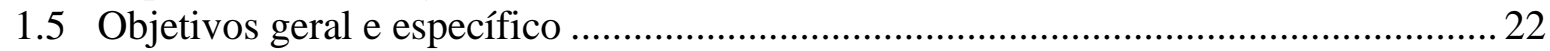

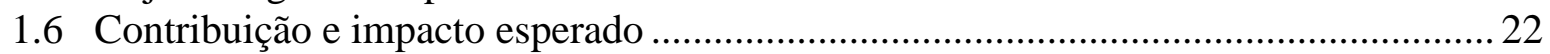

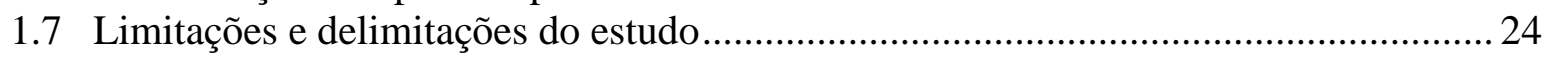

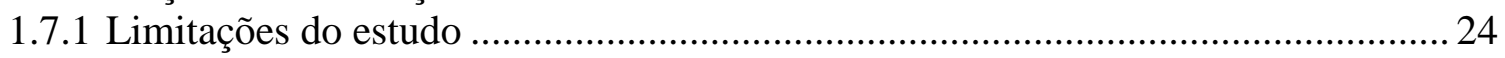

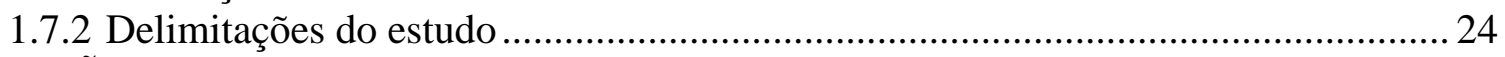

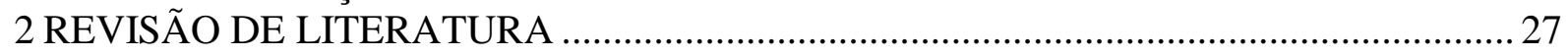

2.1 A Teoria Contratual da Firma ................................................................................. 28

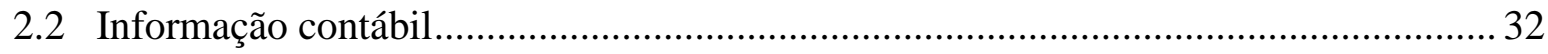

2.2.1 A informação contábil com utilização de indicadores.............................................. 37

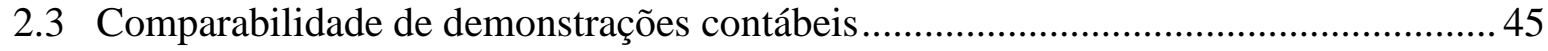

2.4 Conceito de patrimônio líquido: evolução histórica ...................................................49

2.5 Alterações no patrimônio líquido introduzidas pelas Leis $n^{\circ s} .11 .638 / 2007 \mathrm{e}$

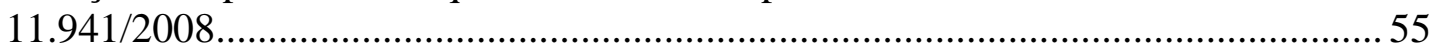

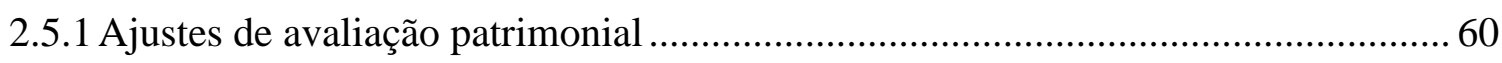

2.5.2 Prêmio recebido na emissão de debêntures e doações e subvenções para

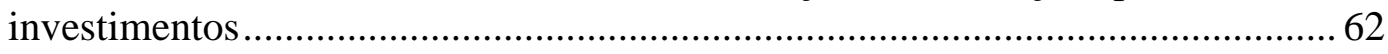

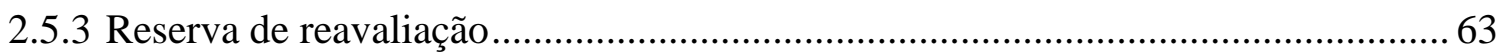

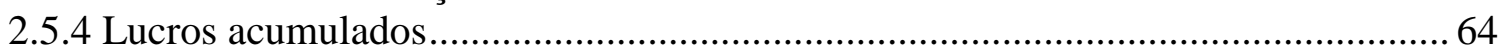

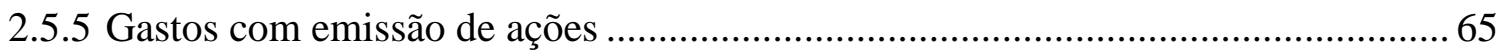

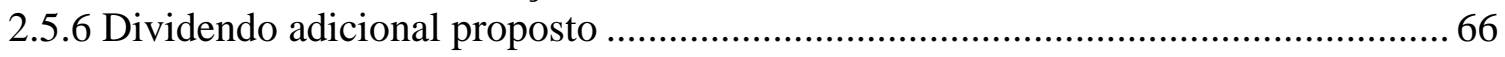

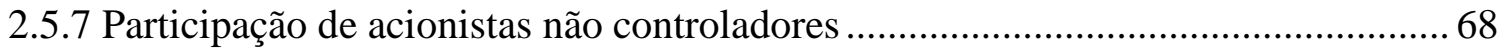

2.6 Limitações relacionadas à ausência de correção monetária das demonstrações

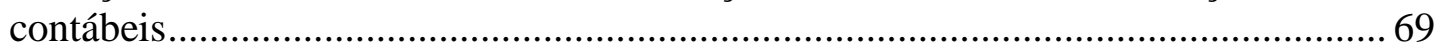

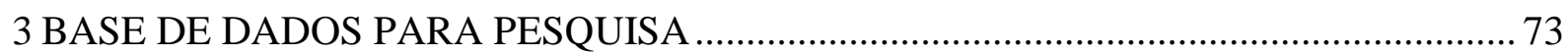

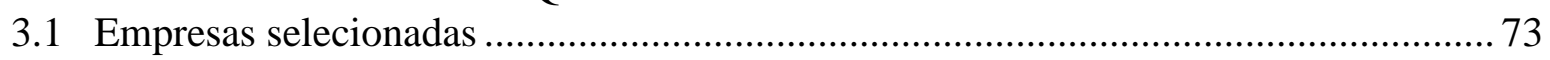

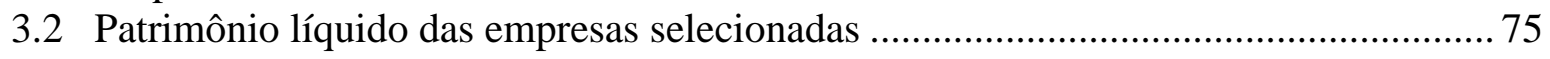

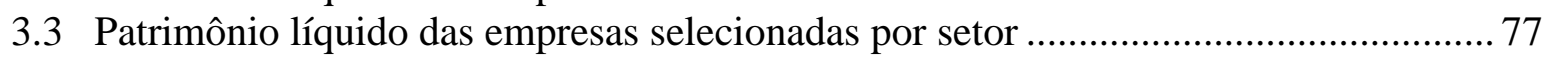

3.4 Composição do patrimônio líquido das empresas selecionadas por setor .................... 78

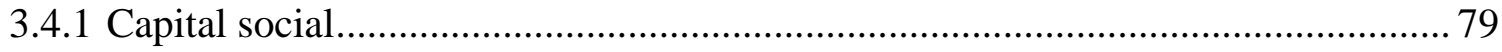

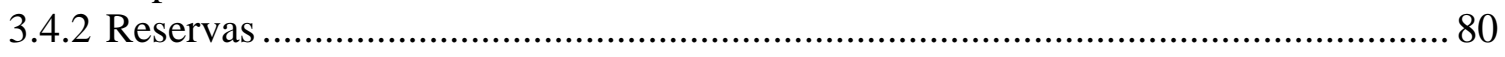

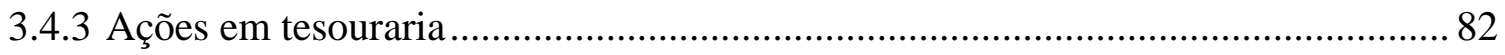

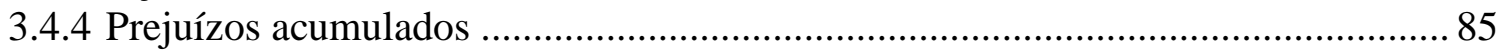

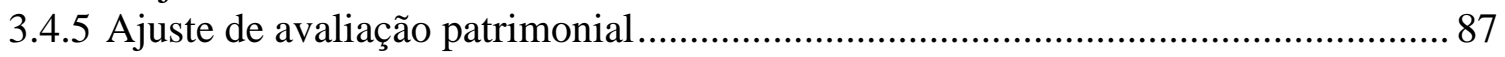

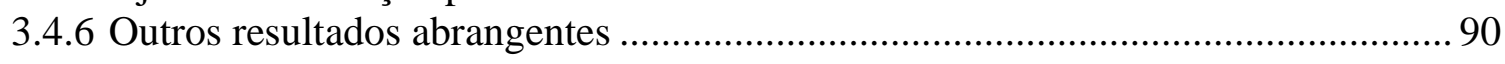

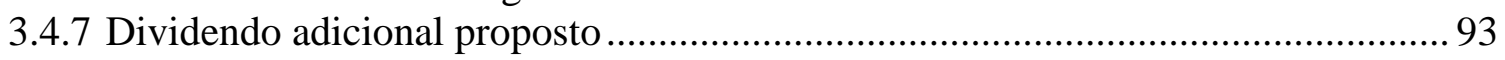

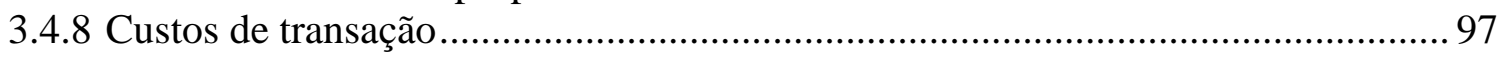

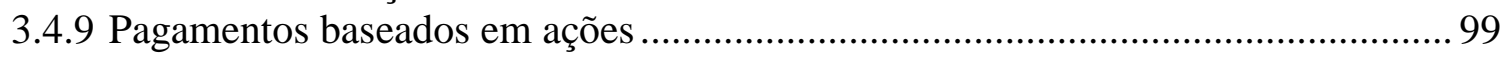

3.4.10 Participação de acionistas não controladores .................................................. 102 


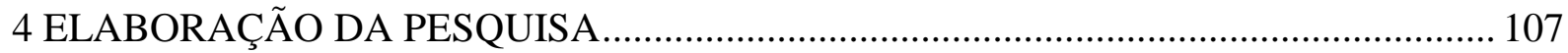

4.1 Questionários aplicados a professores de contabilidade …………………............... 107

4.2 Condições de aplicação do questionário ................................................................. 109

4.3 Características do questionário aplicado ............................................................... 110

4.4 Confiabilidade do questionário aplicado ................................................................ 112

4.5 Respostas do questionário aplicado......................................................................... 114

4.5.1 Questão 1 - O valor do Patrimônio Líquido (PL) de uma empresa é informação importante para os usuários da contabilidade................................................... 116

4.5.2 Questão 2 - A composição do PL é informação importante para os usuários da

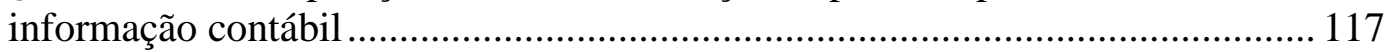

4.5.3 Questão 3 - As alterações provocadas no PL das empresas pelos pronunciamentos do CPC - Comitê de Pronunciamentos Contábeis afetaram significativamente o valor total desse grupo.

4.5.4 Questão 4 - As alterações provocadas no PL das empresas pelos pronunciamentos do CPC afetaram de forma homogênea empresas de setores distintos ................ 119

4.5.5 Questão 5 - As alterações provocadas no PL das empresas pelos pronunciamentos do CPC dificultaram a comparabilidade entre demonstrações contábeis da própria empresa elaboradas antes e após tais alterações

4.5.6 Questão 6 - As alterações introduzidas no PL pelos pronunciamentos do CPC dificultaram a comparabilidade entre demonstrações contábeis de empresas pertencentes a segmentos distintos

4.5.7 Questão 7 - Conhecer a composição do PL e não somente seu valor total se tornou mais importante após as alterações introduzidas pelos pronunciamentos do CPC.

4.5.8 Questão 8 - Considero importante transmitir aos alunos conhecimentos relacionados à composição do PL e como tal composição pode afetar a utilização das informações contábeis

4.6 Correspondência entre dados levantados a partir de balanços publicados e percepção dos professores de contabilidade

4.7 Detalhamento das respostas por titulação dos respondentes ....................................... 127

4.8 Detalhamento das respostas por região geográfica dos respondentes ........................ 136

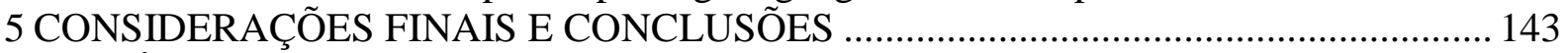

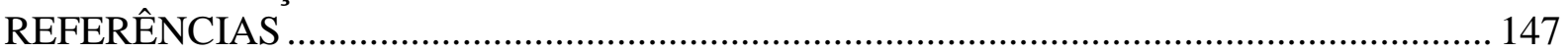

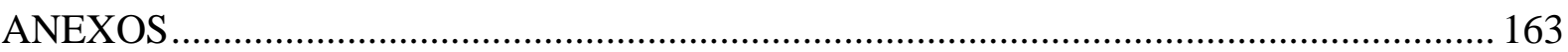

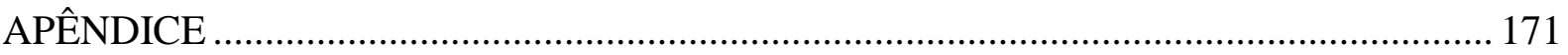




\section{LISTA DE ABREVIATURAS E SIGLAS}

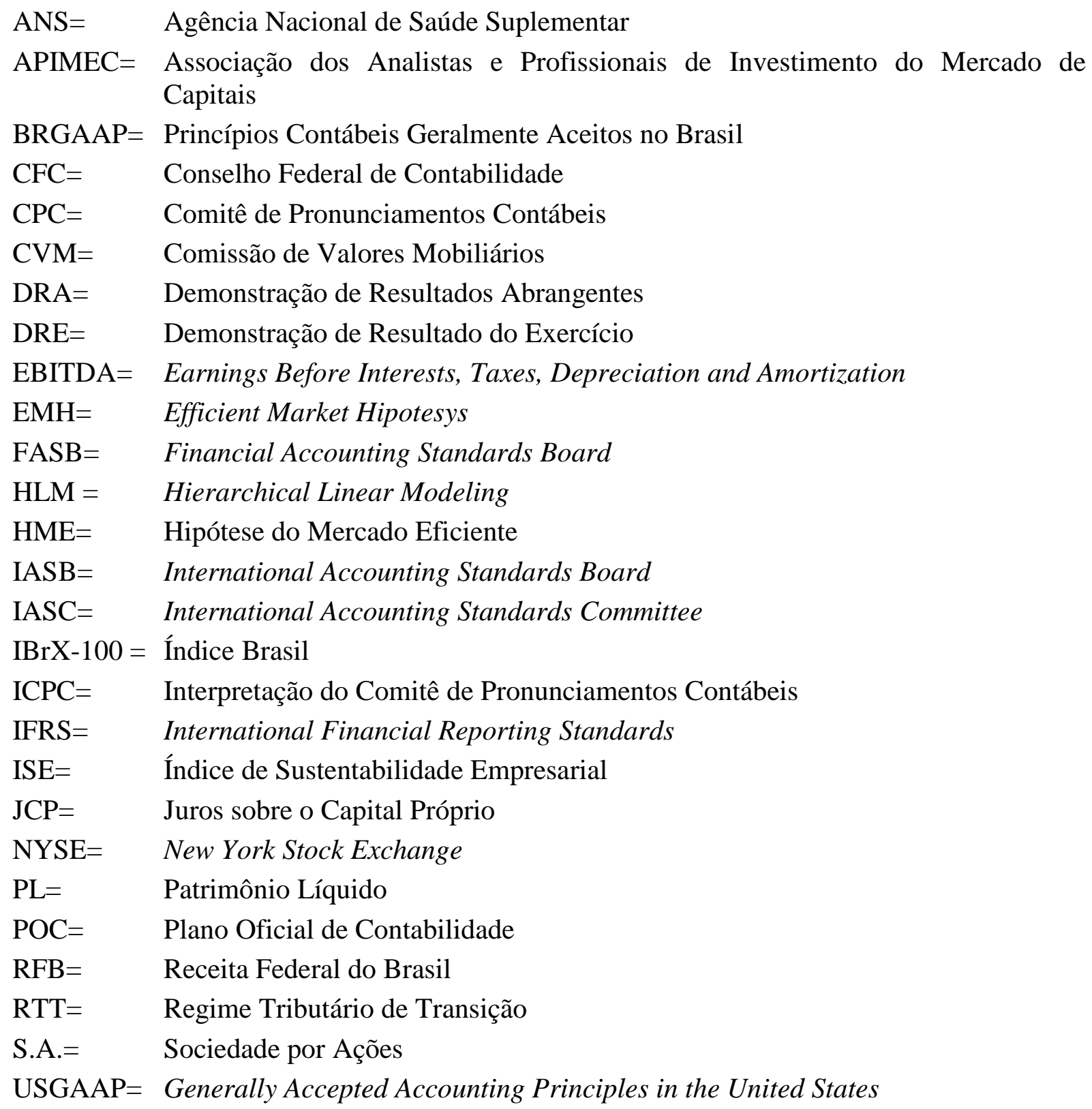





\section{LISTA DE TABELAS}

Tabela 1 - Patrimônio Líquido Souza Cruz S.A. 2010 ........................................................ 12

Tabela 2 - Retorno sobre o PL Souza Cruz S.A. 2010 …..................................................... 12

Tabela 3 - Companhias Abertas em 31 de dezembro de 2010 .............................................. 20

Tabela 4 - Grau de importância dos indicadores pelos especialistas ....................................... 40

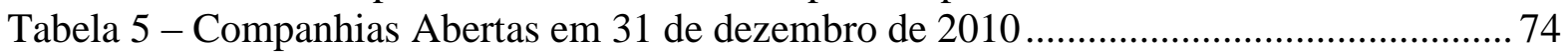

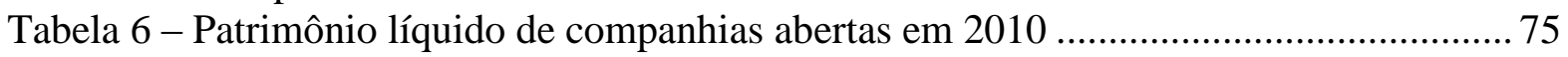

Tabela 7 - Patrimônio líquido de companhias abertas em 2010 apresentado no formato

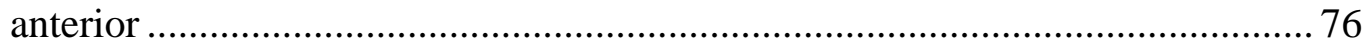

Tabela 8 - Patrimônio líquido ajustado de companhias abertas em 2010 ............................ 77

Tabela 9 - Patrimônio líquido das companhias detalhado por setores $-\mathrm{R} \$$ mil .................... 78

Tabela 10 - Patrimônio líquido das companhias detalhado por setores - \% ......................... 79

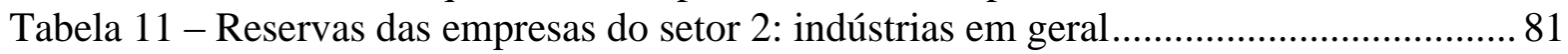

Tabela 12 - Reservas das empresas do setor 8: empresas comerciais .................................. 82

Tabela 13 - Ações em tesouraria das empresas do setor 2: indústrias em geral ..................... 83

Tabela 14 - Prejuízos acumulados das empresas do setor 6: serviços em geral e transportes 86

Tabela 15 - Ajustes de avaliação patrimonial das empresas do setor 5: bancos e atividades

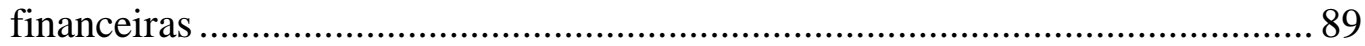

Tabela 16 - Outros resultados abrangentes das empresas do setor 1: agrícola e alimentício. 91

Tabela 17 - Outros resultados abrangentes das empresas do setor 2: indústrias em geral ..... 92

Tabela 18 - Dividendos adicionais propostos das empresas do setor 4: concessionárias de

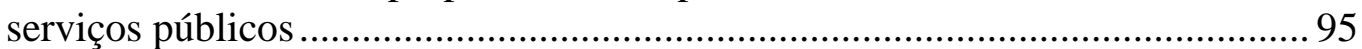

Tabela 19 - Dividendos adicionais propostos das empresas do setor 1: agrícola e

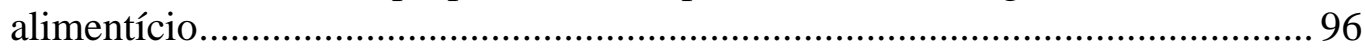

Tabela 20 - Custos de transação das empresas do setor 6: serviços em geral ......................... 98

Tabela 21 - Custos de transação das empresas do setor 3: construção civil e exploração

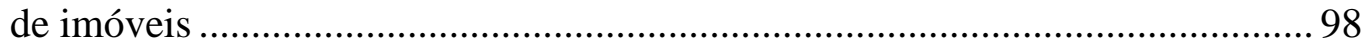

Tabela 22 - Pagamento baseado em ações das empresas do setor 1: agrícola e alimentício 100

Tabela 23 - Pagamento baseado em ações das empresas do setor 6: serviços em geral e

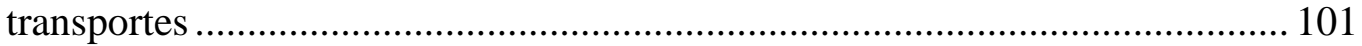

Tabela 24 - Participação de não controladores das empresas do setor 2: indústrias em geral

Tabela 25 - Participação de não controladores das empresas do setor 1: agrícola e alimentício.

Tabela 26 - Participação de não controladores das empresas do setor 4: concessionárias deserviços públicos ................................................................................ 105

Tabela 27 - Divisão das respostas por titulação dos respondentes...................................... 127

Tabela 28 - Frequência relativa de respostas separadas por titulação dos respondentes ..... 128

Tabela 29 - Divisão das respostas por regiões geográficas ............................................... 136

Tabela 30 - Frequência relativa de respostas separadas por região geográfica dos respondentes. 



\section{LISTA DE GRÁFICOS}

Gráfico1 - Distribuição relativa de respostas por unidade da federação.............................. 116

Gráfico 2 - Importância do PL para os usuários da contabilidade ....................................... 116

Gráfico 3 - Importância da composição do PL para os usuários da contabilidade ............... 117

Gráfico 4 - Impacto significativo no PL das empresas pelos pronunciamentos doCPC...... 118

Gráfico 5 - Empresas de setores distintos tiveram seus PLs foram afetados de Formahomogênea pelos pronunciamentos do CPC....................................... 120

Gráfico 6 - Alterações promovidas pelo CPC dificultaram comparabilidade entre demonstrações contábeis da própria empresa elaboradas em períodos

Gráfico 7 - Alterações promovidas pelo CPC dificultaram comparabilidade entre demonstrações contábeis de empresas pertencentes a segmentos distintos

Gráfico 8 - Conhecimento da composição do PL se tornou mais importante após pronunciamentos do CPC

Gráfico 9 - Importância da transmissão aos alunos de conhecimentos relacionados à composição do PL e de como pode afetar a utilização das informações contábeis

Gráfico 10 - Respostas da questão 1 categorizadas por titulação 129

Gráfico 11 - Respostas da questão 2 categorizadas por titulação 130

Gráfico 12- Respostas da questão 3 categorizadas por titulação 131

Gráfico 13 - Respostas da questão 4 categorizadas por titulação

Gráfico 14 - Respostas da questão 5 categorizadas por titulação 133

Gráfico 15 - Respostas da questão 6 categorizadas por titulação 134

Gráfico 16 - Respostas da questão 7 categorizadas por titulação 134

Gráfico 17 - Respostas da questão 8 categorizadas por titulação

Gráfico 18 - Respostas da questão 3 categorizadas por regiões geográficas

Gráfico 19 - Respostas da questão 4 categorizadas por regiões geográficas

Gráfico 20 - Respostas da questão 5 categorizadas por regiões geográficas

Gráfico 21 - Respostas da questão 6 categorizadas por regiões geográficas 140 



\section{INTRODUÇÃO}

\subsection{Apresentação}

A contabilidade societária vem passando por mudanças significativas no Brasil desde a promulgação da Lei no $11.638 / 2007$. Dentre as mudanças introduzidas pelo referido texto legal, algumas alterações foram reconhecidas no patrimônio líquido das empresas.

Dentre as mudanças incorporadas à nossa malha normativa contábil, estão novos componentes do patrimônio líquido. É o caso da conta do patrimônio líquido denominada “ajuste de avaliação patrimonial”. Nessa conta são classificados itens como os resultados atuariais com obrigações de benefícios pós-emprego, ajustes acumulados de conversão de demonstrações contábeis, contrapartidas de atualização pelo valor justo de determinados instrumentos financeiros. Iudícibus et al (2010) caracterizam os ajustes de avaliação patrimonial como sendo as contrapartidas de aumentos ou diminuições de valor atribuído a componentes do ativo e do passivo, decorrentes da aplicação do valor justo sobre esses componentes, enquanto não computadas no resultado do exercício em obediência ao regime de competência.

Os ajustes de avaliação patrimonial estão contidos nos resultados abrangentes que figuram no patrimônio líquido. A variação dos resultados abrangentes deve ser explicitada. Resultado abrangente pode ser definido como a "mutação que ocorre no patrimônio líquido durante um período que resulta de transações e outros eventos que não derivados de transações com os sócios na sua qualidade de proprietários." (Comitê de Pronunciamentos Contábeis, 2009a, p.43). As variações do patrimônio líquido dividem-se em duas categorias: aquelas que refletem transações de capital com os sócios e o resultado abrangente. Ainda, de acordo com o Comitê de Pronunciamentos Contábeis - CPC (2009a), o resultado abrangente é formado por três componentes: o resultado líquido do período, os outros resultados abrangentes e o efeito das reclassificações dos outros resultados abrangentes para o resultado do período.

A interpretação resultante da leitura do artigo 182, parágrafo 3o do texto atual da Lei n6.404/1976, é de que os valores computados na conta de ajustes de avaliação patrimonial serão transferidos para o resultado do exercício proporcionalmente à realização dos ativos e passivos que os originaram (ALMEIDA, Marcelo, 2010). No entanto nem sempre isso ocorre 
por existirem casos nos quais há transferência de valores entre contas do próprio patrimônio líquido. A título de ilustração pode ser considerado o caso da reserva de reavaliação, cujo valor é transferido para a conta de lucros ou prejuízos acumulados à medida que o ativo reavaliado é realizado mediante depreciação, amortização, exaustão, alienação ou baixa. A possibilidade de reavaliação espontânea de ativos por seu valor de mercado quando seu valor é superior ao custo foi eliminada, ainda que tal eliminação esteja em desacordo com as normas internacionais de contabilidade (IUDÍCIBUS et al, 2010). A legislação que implementou a citada eliminação possibilitou às empresas a manutenção dos valores contidos na reserva de reavaliação até a efetiva realização dos respectivos ativos reavaliados, motivo pelo qual ainda é possível encontrar tais valores nas demonstrações contábeis das empresas.

Os gastos na emissão de ações ou outros valores mobiliários patrimoniais, também, passaram a ter tratamento diferente a partir da adoção das normas contábeis emanadas do CPC. Anteriormente, eram tratados como despesas e diluídos no resultado, enquanto, atualmente, devem ser tratados como uma redução dos valores efetivamente obtidos na captação com os sócios. Essa disposição se aplicou nas demonstrações contábeis encerradas a partir de 31/12/2008, em consonância com o Pronunciamento Técnico CPC 08 - Custos de Transação e Prêmios na Emissão de Títulos e Valores Mobiliários (IUDÍCIBUS et al., 2010).

Igualmente merece destaque a classificação que vem sendo feita com relação aos dividendos a pagar. Anteriormente à alteração da legislação societária pela Lei n- 11.638/2007, os valores relativos aos dividendos propostos figuravam integralmente no passivo das empresas. Não obstante, a partir das alterações promovidas pela normatização contábil presentemente em vigor, nem todo o valor relacionado a dividendos a pagar figura no passivo das empresas. Isso porque, no ato de encerramento das demonstrações contábeis, eventualmente nem todo o valor de dividendos a pagar configura uma obrigação, nos termos do conceito atual de passivo, em que representa uma obrigação presente da entidade. Parte desse dividendo proposto, em princípio, pode nunca vir a ser paga, porquanto ainda carece dessa característica de dívida, devendo ainda ser aprovada pela assembleia de acionistas. Sendo assim, a parcela dos dividendos sobre a qual não resta dúvida sobre sua exigibilidade, aquela comumente denominada dividendo mínimo obrigatório, figura no passivo da empresa, ao passo que a parcela que ainda necessita de aprovação, não estando assim incluída no conceito de passivo, figura dentro do patrimônio líquido da entidade, sob a nomenclatura de "dividendos adicionais propostos", nos moldes da interpretação técnica ICPC 08. 
O dividendo "mínimo" obrigatório surgiu como um dos instrumentos de fomento à cultura do mercado de capitais que se desenvolvia quando da publicação da Lei n- 6.404/1976 que o instituiu em seu artigo 202. Também serviu ao propósito de compelir as companhias que não possuíam em seus estatutos sociais uma forma clara de remuneração por meio de dividendos a regular a matéria, e caso permanecesse o silêncio por parte da companhia, prevaleceria, então, o procedimento previsto por esta mesma lei. As terminologias relacionadas ao dividendo tratando-o como mínimo e como obrigatório não significam a mesma coisa. Os dividendos mínimos são conceituados à luz dos lucros remanescentes, enquanto os obrigatórios refletem uma forma impositiva do legislador impelir aquelas companhias cujos estatutos são omissos na questão de fixação de dividendos a fazê-lo. Por vezes, o dividendo mínimo pode ficar "por dentro" do dividendo obrigatório e o dividendo obrigatório pode ficar "por dentro" do dividendo mínimo (IUDÍCIBUS et al., 2010, p.367).

Adicionalmente, pode ser verificada a mudança no tratamento da participação de acionistas não controladores, igualmente conhecida como participação de minoritários. A previsão legal anterior era de que a participação dos minoritários no patrimônio líquido das controladas deveria "ser destacada em grupo isolado no balanço patrimonial consolidado, imediatamente antes do patrimônio líquido" (CONSELHO FEDERAL DE CONTABILIDADE, 1993, p.3;2002, p.7). Posteriormente, a participação de minoritários passou a ser denominada participação de não controladores. A partir de 2009, a participação de sócios não controladores passou a figurar dentro do patrimônio líquido do balanço patrimonial consolidado, porém separada da participação dos sócios controladores (CONSELHO FEDERAL DE CONTABILIDADE, 2009; COMITE DE PRONUNCIAMENTOS CONTÁBEIS, 2009b).

Com a intenção de ilustrar o reflexo dessas alterações nas demonstrações contábeis das empresas, segue Tabela 1com informações contidas no Balanço Patrimonial da Souza Cruz S.A., do exercício de 2010: 
Tabela 1- Patrimônio Líquido Souza Cruz S.A. 2010

\begin{tabular}{lrr}
\hline Em milhões de Reais & \multicolumn{1}{c}{$\begin{array}{c}\text { Valores } \\
\text { consolidados }\end{array}$} & $\begin{array}{c}\text { Demonstração } \\
\text { individual }\end{array}$ \\
\hline PATRIMÔNIO LíQUIDO & & \\
\hline Capital Social Realizado & 854,7 & 854,7 \\
\hline Reservas de Capital & 1,9 & 1,9 \\
\hline Reservas de Lucros & 229,9 & 187,1 \\
\hline Ajustes de Avaliação Patrimonial & 259,9 & 289,8 \\
\hline Lucros Acumulados & - & - \\
\hline Dividendo Adicional Proposto & 749,1 & 561,9 \\
\hline & $2.095,5$ & $1.895,4$ \\
\hline & & \\
\hline TOTAL PASSIVO E PATRIMÔNIO LíQUIDO & $\mathbf{4 . 4 7 4 , 2}$ & $\mathbf{3 . 8 6 8 , 1}$
\end{tabular}

Fonte: Demonstrações contábeis da companhia

Na primeira coluna da tabela 1 encontram-se os valores consolidados de 2010, e na segunda coluna estão os valores da demonstração individual de 2010. Observa-se como valor total do patrimônio líquido a quantia de R 2.095,5 milhões. Entretanto, se fossem excluídos os ajustes de avaliação patrimonial e os dividendos adicionais propostos esse total seria de $\mathrm{R} \$$ 1.086,5 milhões. Isso significa uma redução de 48,15\% do patrimônio líquido decorrente de uma classificação contábil e com a empresa atuando e gerando recursos da mesma maneira, ou seja, a apresentação mudou. Foi alterada a forma de apresentação de informações enquanto a realidade das operações da empresa permaneceu inalterada.

Se fosse calculado o retorno sobre o patrimônio líquido, nesse caso sobre o patrimônio líquido final de cada ano da companhia para simplificação do procedimento, sobre esses dois valores díspares de patrimônio líquido, os resultados seriam:

Tabela 2 - Retorno sobre o PL Souza Cruz S.A. 2010

\begin{tabular}{|c|c|c|c|c|}
\hline \multicolumn{5}{|c|}{ Retorno sobre o PL (final) } \\
\hline & \multicolumn{3}{|c|}{2010} & \multirow{2}{*}{$\begin{array}{c}2009 \\
\text { ajustado }\end{array}$} \\
\hline & 2010 & ajustado & 2009 & \\
\hline Lucro líquido na DRE & $1.449,7$ & $1.449,7$ & $1.484,9$ & $1.484,9$ \\
\hline PL & $2.095,5$ & & $1.895,4$ & \\
\hline PL ajustado & & $1.086,5$ & & $1.043,7$ \\
\hline Retorno s/PL & $69 \%$ & $133 \%$ & $78 \%$ & $142 \%$ \\
\hline
\end{tabular}


Defronte de tal discrepância nos resultados, resta a dúvida sobre qual retorno sobre o patrimônio líquido utilizar. Se for utilizado sobre o PL publicado, a informação que se obtém não é a mesma do que se teria até o exercício de 2007. As mudanças em alguns casos foram significativas, e parte do presente estudo é identificar a percepção dos docentes de contabilidade em relação a esses fatos.

Utilizou-se como ilustração o indicador de retorno sobre o patrimônio líquido por ser um indicador de notória importância para os usuários das informações contábeis, o que foi comprovado por Lyra (2008).

Em evento da Apimec (APIMEC, 2010), a empresa FERBASA - Companhia de Ferro Ligas da Bahia apresentou suas demonstrações contábeis relativas ao exercício de 2010, e somente relativo a um item ainda não trazido à discussão, o custo atribuído (deemedcost) integrante do patrimônio líquido, a empresa apresentou valor inicial de $\mathrm{R} \$ 61,8$ milhões, o que correspondia a 6,7\% do seu patrimônio líquido inicial. Assim como os demais itens apresentados anteriormente, o valor do custo atribuído também não era passível de registro antes da entrada em vigor das novas normas de contabilidade no Brasil e os analistas ali presentes demonstravam curiosidade sobre o tratamento de valores como custo atribuído, mensuração pelo valor justo de ativos biológicos, principalmente no tocante a questões relacionadas à possibilidade ou não de distribuição desses valores como dividendos. Os usuários da contabilidade presentes demonstraram interesse pelas mudanças ocorridas na contabilidade, e esse interesse reflete a importância da contabilidade como fornecedora de informações que subsidiam as relações entre agentes e empresas.

Os usuários das informações contábeis podem ser internos ou externos às empresas, citam-se alguns: investidores; empregados; credores por empréstimos; fornecedores; clientes e governo (IUDÍCIBUS et al., 2010); (COMITÊ DE PRONUNCIAMENTOS CONTÁBEIS, 2008a); (HENDRIKSEN; VAN BREDA, 1999); (ERNST \& YOUNG; FIPECAFI, 2010); (FINANCIAL ACCOUNTING STANDARD BOARD, 1978); (IFRS FOUNDATION, 2010).

Os usuários utilizam, então, a contabilidade para conseguir informações sobre as empresas. Podem ter percebido que houve mudanças na contabilidade adaptando-se a elas ou, então, podem não ter percebido as mudanças, continuando, dessa maneira, a utilizar as informações contábeis como se fossem as mesmas. 
A questão sobre o patrimônio líquido não é restrita somente a ele. Por definição, o patrimônio líquido é resultante da diferença entre ativo e passivo. Hendriksen e Van Breda (1999, p.421422) corroboram afirmando:

Esse patrimônio, porém, não é definido independente de ativos e passivos, e talvez não possa ser assim definido, porque não é mais do que um resíduo. É simplesmente a diferença entre ativos e passivos. Numa formulação mais geral, é a diferença entre recursos e obrigações.

Os autores, reconhecendo a ausência de uma definição de patrimônio dos acionistas, chegam a recomendar o abandono da distinção entre patrimônio e exigível, passando, portanto, a serem reconhecidas todas as obrigações como patrimônio no sentido amplo da palavra (HENDRIKSEN; VAN BREDA, 1999).

Se o patrimônio líquido sofreu alterações, concluiu-se que ativos e passivos já não são os mesmos. Assim, o resultado que se obtém por meio de parte dos indicadores contábeis já não possui o mesmo conteúdo que possuía anteriormente. Com as normas contábeis atuais ao se calcular retorno sobre o patrimônio líquido, está se calculando não somente o retorno sobre o capital dos sócios acrescido dos resultados acumulados apurados periodicamente, mas também sobre alguns recursos que podem, eventualmente, nunca vir a transitar pelo resultado, e por consequência nunca se tornar disponível para os sócios ou, ainda, sobre valores que tenham em sua essência significado de dívida, ainda que para com os sócios, como é o caso dos dividendos adicionais propostos.

Há um projeto no International Accounting Standards Board - IASB que busca definir "outros resultados abrangentes". Uma definição para "outros resultados abrangentes" aparece como uma das mais importantes, se não a mais importante. Durante as duas últimas décadas, o IASB e seu predecessor, IASC têm utilizado de maneira crescente conceitos de valor de mercado e valor justo na mensuração de ativos e obrigações em diversas áreas, mais notadamente na área de instrumentos financeiros. Tem sido gradualmente mais desafiador entender performance dada a expansão do uso de valor justo juntamente com custos históricos, particularmente quando o foco é uma única estatística: lucro ou prejuízo (IFRS FOUNDATION, 2012a) 


\subsection{Problema}

O patrimônio líquido das empresas é composto não só por transações relacionadas aos acionistas ou sócios, mas também pelos resultados abrangentes, conforme mencionado. $\mathrm{O}$ conceito de resultados abrangentes agrupa resultados do período, outros resultados abrangentes e transferências de outros resultados abrangentes de períodos anteriores para resultado do período. $\mathrm{O}$ assunto relacionado ao patrimônio líquido tem sido tratado com maior atenção desde a alteração da legislação societária promovida pela Lei no 11.638/2007, em virtude da criação do subgrupo ajustes de avaliação patrimonial nesse grupo. A partir de então, foi instituída uma demonstração específica para evidenciar a movimentação contida nesse subgrupo, que é a Demonstração de Resultados Abrangentes. Os outros resultados abrangentes podem representar parcela significativa do patrimônio líquido, assim como itens atualmente classificados no patrimônio líquido que não eram classificados em tal grupo anteriormente, e essas alterações interessam ao presente estudo.

Conceitualmente, o patrimônio líquido é um valor residual, resultante da diferença entre ativo e passivo. Por ser assim, representa a origem de recursos proveniente majoritariamente dos sócios. Esses recursos poderiam ter sido retirados da empresa pelos sócios, total ou parcialmente, mas não o fizeram. Os recursos ficaram em posse da empresa, sendo investidos na operação da empresa.

A composição do patrimônio líquido vem sofrendo alterações que podem ter sido ou não percebidas pelos usuários da informação contábil. Essas inquietações conduzem o presente estudo ao seguinte problema de pesquisa: identificar a percepção por parte dos docentes de contabilidade, sobre as mudanças significativas e recentes que afetaram o patrimônio líquido das empresas.

Essa questão da percepção da mudança pela qual o patrimônio líquido vem passando tem importância para que se possa compreender o que de fato está lá contido. A título de exemplo pode ser citado o caso recente da empresa Energisa, que em suas demonstrações contábeis relativas ao primeiro trimestre de 2011 registrou, em seu patrimônio líquido, os valores relativos à captação que fez no mercado, por meio de títulos denominados bônus perpétuos, mas que permitia à empresa pagar os juros na data prevista ou, então, postergar esse pagamento a seu critério e efetuar o pagamento quando for mais conveniente. Importante 
ressaltar que tal forma de contabilização não prevaleceu na publicação de suas demonstrações contábeis anuais. A empresa esclarece em suas notas explicativas, item 22, que originalmente havia registrado o valor relativo a tais "notas perpétuas híbridas" como instrumento patrimonial, considerando os termos dos CPC 38, 39 e 40, convergidos às IAS 39, IAS 32 e IFRS 7. Em tais notas a administração relata o entendimento "que um incentivo ou a intenção da administração para pagar não geram uma obrigação presente para a entidade e por isto não pode gerar classificação de um instrumento financeiro como passivo financeiro" e que o tratamento, então, dispensado a essa contabilização foi encontrado, também, em "várias companhias em vários países que adotam as normas internacionais de contabilidade (IFRS)" (ENERGISA, 2012).

A companhia, ainda, relata os trâmites que a fizeram alterar sua forma de contabilização (ENERGISA, 2012):

\begin{abstract}
Em 31 de outubro de 2011, a Superintendência de Relações com Empresas (SEP), emitiu o Ofício/CVM/SEP/GEA-5/No 247/2011, apresentando sua interpretação sobre a classificação contábil das Notas Perpétuas Híbridas como instrumento financeiro passivo e determinou a reclassificação contábil para o grupo do passivo. A Companhia recorreu da decisão ao colegiado da CVM, que manteve a determinação de reclassificação confirmada em Ata do Colegiado de 24 de janeiro de 2012. A CVM observou que "se trata de uma decisão complexa, pois as normas contábeis internacionais certamente têm diversas leituras possíveis e, portanto, diversas respostas defensáveis". No entanto, a CVM considerou, dentre outros aspectos, que o "curso normal dos negócios de uma companhia, exige que, havendo lucros, tais lucros sejam distribuídos em algum momento, que não está inteiramente sob o controle dos administradores, do acionista controlador, ou mesmo, da assembleia geral....
\end{abstract}

Em estrita obediência às determinações da CVM, a Administração reclassificou os títulos perpétuos para o passivo não circulante - empréstimos e financiamentos, bem como reflete no resultado do exercício todos os encargos de remuneração dos títulos, enquanto anteriormente os juros quando declarados eram deduzidos do patrimônio líquido.

Fica assim, com base em tais relatos, ilustrada a presença da subjetividade, uma vez que as normas internacionais possuem várias leituras possíveis e posições defensáveis, como mencionado acima.

O exemplo descrito demonstra a relevância acerca do conhecimento do conteúdo do patrimônio líquido das empresas, largamente utilizado pelos usuários das informações contábeis.

Contudo, ao analisar a percepção dos usuários da contabilidade, neste trabalho delimitados a docentes de contabilidade, é necessário que o assunto seja abordado sob a ótica da teoria 
contratual da firma. De acordo com essa teoria, a firma é composta por contratos, de diversas naturezas, e qualquer relação estabelecida entre a firma e seus agentes é feita por intermédio de um ou outro tipo de contratos. Contratos que podem até mesmo não serem explícitos ou formais, mas estabelecem a relação de troca entre os agentes e a firma. Os agentes fornecem algo à firma e em troca recebem sua parte no bolo, e o funcionamento adequado da empresa depende do equilíbrio contratual estabelecido (LOPES; MARTINS, 2007).

A contabilidade surge sob esse contexto como uma forma de controle desses contratos. Cada usuário fornece algo à empresa e recebe algo em troca. Dessa forma os usuários da contabilidade podem averiguar o equilíbrio de suas relações. Os acionistas podem avaliar o risco e o retorno de seus investimentos, os administradores o desempenho da entidade, os financiadores a situação da entidade viabilizando ou não novos financiamentos, e assim por diante. E os docentes de contabilidade utilizam a informação contábil na sua função, uma vez que são responsáveis por colocar em contato com o universo contábil aqueles que serão usuários e também elaboradores de demonstrações contábeis.

\subsection{Questão de pesquisa}

A questão de pesquisa que direciona este estudo é: qual a percepção dos docentes de contabilidade com relação às mudanças no patrimônio líquido promovidas a partir de 2010?

Para que a questão de pesquisa possa ser respondida, o estudo foi realizado em duas etapas. $\mathrm{Na}$ primeira etapa, identificaram-se alterações presentes no patrimônio líquido das empresas, mais, especificamente, companhias abertas. Na segunda, foram captadas percepções de docentes de contabilidade sobre a dimensão das alterações no patrimônio líquido das empresas.

A formulação clara de um problema precede a construção de hipóteses. O papel fundamental da hipótese, nesta pesquisa, é o de sugerir explicações para os fatos, e originam-se das mais diversas fontes (GIL, 1999). 
Neste trabalho está presente a hipótese de que os docentes de contabilidade, como usuários das informações contábeis, ainda não assimilaram completamente a extensão das alterações normativas da contabilidade relacionadas ao patrimônio líquido das empresas.

\subsection{Aspectos metodológicos}

A finalidade da Ciência é tratar a realidade teórica e praticamente. Para que tal finalidade seja atingida, colocam-se vários caminhos. Disso trata a metodologia, das formas de se fazer Ciência. Metodologia é uma preocupação instrumental (DEMO, 2010).

O tipo de estudo desenvolvido teve como critério de classificação de pesquisa o apresentado por Vergara (2009), quanto aos fins e aos meios.

Quanto aos fins, pode ser classificado como descritivo, por expor características de determinada população, no presente estudo caracterizada pelos docentes de contabilidade, podendo, também, estabelecer correlações entre variáveis e definir sua natureza. A pesquisa identificou as alterações incidentes sobre os componentes do patrimônio líquido e seus reflexos aos usuários da informação contábil.

Quanto aos meios, classifica-se como uma pesquisa ex post facto, documental e de campo. Ex post facto por fazer referência a fatos já ocorridos, aplicável quando o pesquisador não pode controlar ou manipular variáveis, seja porque suas manifestações já ocorreram, ou então porque as variáveis não são controláveis. Documental por ser realizada em documentos conservados no interior de órgãos públicos e privados de qualquer natureza, ou com pessoas. Classifica-se como pesquisa de campo por se tratar de uma investigação empírica no local onde ocorreu ou ocorre o fenômeno, ou então onde pode ser explicado, nesse caso especificamente, utilizando-se de questionários.

O ponto inicial do trabalho foi a investigação do referencial teórico que sustentou o conceito de patrimônio líquido ao longo das últimas décadas. A mudança do conceito de patrimônio líquido e de sua apresentação serviram como pano de fundo para a interpretação dos resultados obtidos a partir deste estudo. 
Os conceitos relacionados à lucratividade e à estrutura de capital foram percorridos, com o desígnio de averiguar se as alterações do patrimônio líquido têm repercutido na literatura contábil recente, ou então se elas continuam abordando tais questões como eram abordadas anos atrás.

Foram, também, pesquisadas publicações recentes, acadêmicas e técnicas, com a intenção de identificar se as mudanças citadas no patrimônio líquido têm sido ou não consideradas e se tais considerações se mostrariam oportunas no sentido de melhorar a qualidade da informação contábil para seus usuários.

A pesquisa empírica do trabalho, que inquire em face da "experimentável, mensurável da realidade" (DEMO, 2011, p.70), foi inicialmente desenvolvida a partir de dados das companhias abertas, dados esses provenientes das bases da Revista Exame Melhores e Maiores ${ }^{\circledR}$, e das demonstrações contábeis publicadas pelas companhias, disponíveis no site da Comissão de Valores Mobiliários - CVM. Esses dados permitiram a obtenção de informações sobre a composição do patrimônio líquido das entidades, para que pudessem ser então comparados com os valores desses mesmos grupos, porém sem a inclusão dos novos partícipes.

As informações provenientes das companhias abertas são relativas ao exercício encerrado em 31 de dezembro de 2010. A relação das empresas classificadas, nessa categoria, na ocasião, foi obtida a partir de arquivo fornecido pelo atendimento da BM\&FBovespa, como evidencia o anexo 1. O arquivo fornecido pela instituição contém, além das empresas com títulos patrimoniais ou de dívida negociados na bolsa, também entidades cujos títulos são negociados em mercado de balcão, organizado ou não.

Foi necessário elaborar um filtro para se chegar à quantidade de empresas indicada no próprio site da BM\&FBovespa, além de pesquisa sobre aberturas de capital recentes na época, que eventualmente poderiam não estar contidas no arquivo recebido. A relação de empresas que abriram capital recentemente pode ser encontrada no site da BM\&FBovespa (2012b), e a listagem encontra-se no anexo 2.

O número exato de companhias abertas, em 31 de dezembro de 2010, segue demonstrado na Tabela 3: 
Tabela 3 - Companhias Abertas em 31 de dezembro de 2010

\begin{tabular}{|l|r|r|}
\hline Mercado & dez/10 & Part. $(\%)^{*}$ \\
\hline Novo Mercado & 112 & $23,80 \%$ \\
\hline Nível 2 & 18 & $3,80 \%$ \\
\hline Nível 1 & 37 & $7,90 \%$ \\
\hline Básico e BDRs & 304 & $64,50 \%$ \\
\hline Total & $471^{*}$ & $100,00 \%$ \\
\hline
\end{tabular}

Fonte: BM\&FBovespa, 2010

As companhias listadas são divididas em setores, mais especificamente 92 setores, muitas vezes com descrições bem próximas, e essa informação foi obtida da relação de companhias listadas fornecidas pela BM\&FBovespa.

Com a finalidade de se identificar características que influenciaram na composição do patrimônio líquido das empresas, esses 92 setores foram resumidos a 8, unindo-se aqueles com características similares, como, por exemplo, empresas de telefonia móvel e empresas de telefonia fixa. Foram, também, reclassificados os setores de algumas companhias que apareceram como "outros" ou "diversos", com a intenção de tornar a análise mais precisa. A maior parte das companhias classificadas originalmente com o setor "outros" acabou sendo reclassificada para "holdings diversas". Com essa classificação, por setores unidos por suas características básicas, foi possível traçar características que afetam o patrimônio líquido de empresas pertencentes a um determinado setor.

Em momento preliminar à junção das empresas em setores similares foram excluídas da amostra empresas que não continham informações, por não terem apresentado suas demonstrações contábeis ou por essas demonstrações contábeis não estarem disponíveis nos sites da CVM e da BM\&FBovespa, como foi o caso das empresas Botucatu Textil, Cimob Participações, International Finance Corporation e Wiest. O número de empresas ficou reduzido para 463 e não mais 471. As 463 empresas foram divididas em 8 setores que agruparam companhias com características similares, com o objetivo de captar informações sobre qual tipo de atividade sofreu maior influência por parte dos componentes introduzidos ao patrimônio líquido, e também investigar a composição do patrimônio líquido desses setores. 
Adicionalmente foi realizada mais uma exclusão, que foi a remoção das demonstrações contábeis de companhias que tiveram suas demonstrações contábeis consolidadas por outras que também figuraram como companhias abertas nesse ano de 2010, totalizando 47 companhias. Esse procedimento impediu que as informações contábeis fossem consideradas duplamente, na própria companhia e na companhia que consolidou essas demonstrações. Assim, essa remoção não resultou em perda de informação das companhias excluídas, ao contrário, evitou possíveis duplas contagens.

Opcionalmente poderiam ter sido utilizadas as demonstrações contábeis individuais, evitandose, dessa forma, a possibilidade de existir uma dupla contagem de valores decorrente das participações em controladas que também participam da listagem de empresas da BM\&FBovespa. Entretanto, considerou-se que haveria perda de informação, uma vez que, nas demonstrações consolidadas, a maioria das empresas controladas que possuem valores representados nas demonstrações consolidadas não são companhias abertas, e se esse caminho alternativo fosse escolhido, poderia haver a desconsideração de algumas informações contábeis.

A escolha de utilização de dados das companhias abertas justifica-se pelo mercado financeiro ser "um dos maiores usuários da informação contábil por intermédio de analistas, corretoras, investidores institucionais e individuais, bancos de investimentos e outros agentes." (LOPES; MARTINS, 2007, p.9).

Em uma segunda etapa, com a utilização de questionários, capturou-se a percepção de usuários de informações contábeis, mais especificamente professores de contabilidade no ensino superior, acerca do tema central deste estudo. Questionários foram aplicados aos docentes de cursos de bacharelado em Ciências Contábeis que, pela natureza de sua função, estão constantemente em contato com as informações contábeis de companhias abertas.

O questionário, que é um conjunto ordenado e consistente de perguntas relacionadas a variáveis e situações que se pretende descrever ou medir, representa um importante e popular instrumento de coleta de dados para uma pesquisa social (MARTINS; TEÓPHILO, 2009).

A avaliação da confiabilidade e validade dos questionários aplicados foram realizadas por meio do coeficiente de Cronbach que, segundo Martins e Teóphilo (2009, foi desenvolvido 
por J.L. Cronbach e sua aplicação produz valores que vão de 0 a 1 ou de $0 \%$ a $100 \%$. Quando o coeficiente obtido é superior a 70\%, há confiabilidade nas medidas. Hair et al (2005) afirmam ser aceitável o coeficiente em 0,60 quando se trata de pesquisa exploratória.

A partir dos dados obtidos, elaboraram-se análises com o propósito de identificar alterações decorrentes das mudanças promovidas recentemente no patrimônio líquido das entidades. Por fim, preparou-se uma ilação a respeito da percepção das mudanças recentes ocorridas no patrimônio líquido por parte dos usuários da informação contábil.

\subsection{Objetivos geral e específico}

Espera-se, como objetivo geral deste trabalho, esclarecer questões relacionadas à extensão das alterações promovidas no patrimônio líquido das empresas por força da alteração da malha normativa contábil brasileira em função da internacionalização dessas normas. Espera-se, conjuntamente, revelar a percepção de usuários da contabilidade, mais especificamente docentes da área contábil, a respeito dessas alterações.

Como objetivos específicos são apresentados:

a) Elaboração de levantamento de dados contábeis do patrimônio líquido de companhias abertas relativos ao ano calendário de 2010 permitindo a obtenção da dimensão dos valores referentes às já citadas alterações normativas;

b) agrupamento das companhias abertas utilizadas no estudo em segmentos, cujas atividades estejam relacionadas viabilizando a comparação da intensidade das alterações normativas em segmentos distintos;

c) disponibilização de questionários contendo perguntas sobre as alterações das normas contábeis para que docentes em cursos de bacharelado em Ciências Contábeis possam expressar suas percepções sobre o tema estudado.

\subsection{Contribuição e impacto esperado}

O patrimônio líquido não possui a mesma composição que possuía anteriormente à Lei no 11.638/2007 e, por apresentar composição modificada, a utilização que é feita com suas 
informações também deveria ser diferente. Ao se comparar valores de patrimônio líquido é possível que estejam sendo comparadas grandezas não comparáveis entre si, tanto ao longo do tempo como entre empresas distintas. Ter conhecimento sobre as diferenças existentes é de importância para os usuários das informações contábeis, para que não utilizem informações diferentes como se fossem similares.

Estudos recentes apontam que há diferenças significativas entre o Patrimônio Líquido das empresas antes e após as alterações promovidas pela Lei no 11.638/2007 (FURUTA et al., 2010), e entre as apurações do patrimônio líquido seguindo-se as normas emanadas pelo CPC e as normas anteriormente vigentes - BRGAAP (COSTA et al, 2011).

A contabilidade fornece informações aos seus usuários para que esses tomem suas decisões. Ela serve como meio de comunicação para que os usuários avaliem se o que estão recebendo da entidade em troca dos recursos que fornecem a ela está de acordo com o esperado. De acordo com a Teoria Contratual da Firma, cada agente que interage com a empresa fornece algo a ela e espera algo em troca.

A teoria científica é imprescindível para apoiar a formulação da pesquisa e entendimento dos resultados. Assim, o pesquisador deve ter conhecimento das possíveis teorias a serem empregadas em sua pesquisa. Nesse sentido, ao esclarecer questões contábeis significativas, este estudo pretende contribuir para a importância e a utilidade das informações contábeis aos seus usuários, partindo-se de uma plataforma teórica denominada teoria contratual da firma, na qual a empresa é vista como um conjunto de contratos entre diversos participantes, e a contabilidade surge com o papel de coordenar os vários contratos existentes entre os agentes ligados à empresa (LOPES; MARTINS, 2007).

À medida que a apresentação das informações contábeis sofreu alterações, estas podem refletir nas decisões dos seus usuários. Surge, então, a necessidade de se avaliar a extensão dessas mudanças no patrimônio líquido das empresas e a percepção dos docentes de contabilidade a esse respeito. 


\subsection{Limitações e delimitações do estudo}

\subsubsection{Limitações do estudo}

Por utilizar-se de demonstrações contábeis divulgadas publicamente, o trabalho esteve restrito às companhias abertas, não sendo possível extrapolar avaliações obtidas às demais companhias brasileiras.

A falta de reconhecimento da inflação nas demonstrações contábeis igualmente surgiu como limitação, à medida que informações contábeis a custo histórico não possuem a mesma qualidade das informações se essas fossem apresentadas com a utilização do custo histórico corrigido. A título de ilustração, apresenta-se a conta de capital social, uma das mais representativas dentro do patrimônio das empresas, que figura pelo seu valor histórico. Por representar o valor investido pelos sócios na empresa, provavelmente seria de maior utilidade uma informação com valor atualizado que representasse o efetivo valor investido na empresa, em sentido amplo, e não o valor já defasado e sem representação fiel de seu significado. Ao se comparar demonstrações contábeis sem correção monetária os valores apresentados pelos patrimônios líquidos das empresas podem não refletir adequadamente as grandezas que representam.

\subsubsection{Delimitações do estudo}

O presente estudo não pretendeu elaborar inferências sobre os demais componentes do balanço patrimonial que não sejam integrantes do patrimônio líquido. Não tentou do mesmo modo captar percepções de usuários da contabilidade que não sejam docentes em cursos de bacharelado em Ciências Contábeis.

Foram utilizadas demonstrações contábeis de companhias abertas do ano de 2010, mas não na sua totalidade. No caso de companhias abertas que tiveram suas informações contábeis consolidadas em controladoras também companhias abertas, suas demonstrações contábeis foram excluídas do levantamento com o objetivo de se evitar dupla contagem de valores.

Pelo fato de do estudo se ater ao ano-calendário de 2010 não se pretendeu afirmar que a extensão das alterações contábeis seja idêntica ou aconteça com a mesma intensidade nos demais períodos. 
Ainda que possa estar implícito no modelo de estudo a ser realizado, foi abordada uma face da contabilidade, que é denominada contabilidade financeira ou societária, não se almejando, em momento algum do trabalho, exceder tais limites.

Os respondentes dos questionários não foram escolhidos de forma aleatória, impossibilitando assim inferências estatísticas a todo universo de docentes em cursos de bacharelado em Ciências Contábeis. 



\section{REVISÃO DE LITERATURA}

Este capítulo tem por objetivo apresentar a revisão de literatura que sustenta o desenvolvimento do trabalho.

A apresentação da Teoria Contratual da Firma, no item 2.1, demonstrará a relação entre os agentes econômicos e as empresas, e a forma como a contabilidade é utilizada para que esses agentes obtenham informações sobre as empresas com o intuito de mensurar a contrapartida recebida em troca dos recursos aplicados nessas empresas.

A utilização da informação contábil pelos usuários, incluindo-se a de indicadores, é apresentada no item 2.2, como forma de dar sequência ao raciocínio de que a contabilidade fornece informações aos usuários e pode ser considerada como um canal de comunicação entre eles e o que acontece nas empresas.

Os usuários da informação contábil precisam comparar as informações recebidas pela contabilidade com as que já haviam sido recebidas anteriormente relacionadas à mesma empresa ou, ainda, com empresas pertencentes a segmentos distintos, e essa comparabilidade é abordada no item 2.3.

Como parte integrante da informação contábil fornecida aos usuários e igualmente como objeto de estudo deste trabalho, são apresentadas no item 2.4 teorias relacionadas ao patrimônio líquido, assim como alterações normativas recentes que impactaram na sua composição.

Uma análise mais detalhada das alterações recentes, promovidas no patrimônio líquido, será explorada no item 2.5, com exposição de componentes que foram criados assim como os que deixam de figurar nesse grupo.

Ao final, são expostas, no item 2.6, limitações relacionadas à utilidade das informações contábeis fornecidas pelas empresas resultantes da ausência de correção monetária das demonstrações contábeis, legalmente vedada desde 1996. 


\subsection{A Teoria Contratual da Firma}

A contabilidade é uma Ciência Social Aplicada e o objetivo de sua existência é o fornecimento de informações úteis aos seus usuários. Esses usuários podem ser internos ou externos às empresas. Isso a caracteriza como uma disciplina pragmática, "existe porque se julga que ela é útil.” (HENDRIKSEN; VAN BREDA, 1999, p.84).

Por seu estreito relacionamento com seus usuários e pela sua utilidade, pode-se dizer que a contabilidade é relevante e tem consequências econômicas. Nesse contexto, argumentos puramente teóricos tendem a ser sobrepujados pelas implicações imaginadas nas partes afetadas. Há inúmeros exemplos de consequências econômicas diretas e indiretas das regras contábeis, como seria o caso de uma empresa divulgar uma situação financeira inferior à esperada, por decorrência da existência de um novo padrão contábil. Nesse caso, os acionistas existentes poderão ser prejudicados com a queda do preço das ações, os prêmios baseados nos lucros pagos a executivos também cairiam, eventualmente dívidas venceriam imediatamente como resultado de aplicação de cláusulas pactuadas com credores nas quais estejam previstas. Assim, a linguagem e a terminologia são exercícios intelectuais extremamente valiosos, como também o são as definições e as delimitações de conceitos, por aprimorar o pensamento em contabilidade, mas todos eles tendem a sucumbir à força dos argumentos econômicos (HEDRIKSEN; VAN BREDA, 1999).

A teoria contratual da firma considera essas repercussões econômicas geradas pela contabilidade, analisando-a como instrumento que faz a mediação entre o objeto da contabilidade, que seria o patrimônio da entidade e os usuários da informação contábil.

A empresa é formada por relações, que são disciplinadas por contratos. Uma empresa organiza a produção, estabelece contratos relacionados a negociações e busca minimizar o custo desses contratos. O número de contratos acaba sendo reduzido, pela substituição de alguns por um único, como seria o caso de contratação de um funcionário no lugar de negociar um contrato de prestação de serviço individualmente. Empresas podem preferir contratos de longo prazo com fornecedores para, assim, minimizar seus custos de contratação, não precisando mais elaborar vários pequenos contratos, ainda que exista uma incerteza envolvida na questão, pois quanto maior o prazo de contratação, mais difícil a especificação daquilo que se contrata, partindo da ideia de que as condições mudam com o passar do tempo. 
Situações nas quais contratos de prazo muito curto são insatisfatórios viabilizam o surgimento da firma. A operação de um mercado custa alguma coisa, e os custos podem ser economizados ao se formar uma organização e ao permitir uma autoridade a dirigir recursos. O empreendedor desempenha sua função com o menor custo do que as transações de mercado que ele substitui, porque é sempre possível voltar ao mercado aberto caso ele falhe na sua execução. É relevante estudar o equilíbrio da firma e parece improvável que uma firma surgiria na ausência da incerteza. Economicamente faz sentido reunir contratos para compor uma firma (COASE, 1937).

Sob o ponto de vista da teoria contratual da firma, a empresa é vista como um conjunto de contratos entre os diversos participantes. Cada participante possui um interesse específico na empresa, e em troca oferece algo para essa empresa. Essa troca se dá por meio de contratos que são estabelecidos, de forma explícita ou não. Empregados contribuem com sua força de trabalho e recebem salário. Acionistas fornecem capital e recebem dividendos e ganho de capital. Fornecedores contribuem com bens e serviços e recebem dinheiro. O governo contribui garantindo a estabilidade institucional e recebe os tributos. Enfim, qualquer relação estabelecida entre a firma e seus agentes é feita por intermédio de um contrato, explícito ou não (LOPES; MARTINS, 2007).

Para se entender a contabilidade, a firma pode ser vista como um conjunto de contratos entre agentes que agem de forma racional. Agir de forma racional nesse contexto significa que dentro das limitações de suas oportunidades e informações, eles não escolhem de forma consciente uma ação menos desejável do que outras mais desejáveis. Esses contratos podem ser explícitos ou implícitos, de curto ou de longo prazo. No modelo neoclássico presente na microeconomia a empresa é um ator econômico operado pelo empreendedor-gestor com objetivo bem definido, que geralmente é o lucro. No modelo da teoria contratual, a firma não é ela própria um ator, não tem objetivo ou motivação por si mesma e não é identificada com nenhum agente. No lugar disso, é vista como uma arena na qual agentes econômicos motivados por si mesmos agem com base em regras mutuamente combinadas ou aplicadas para atingir seus respectivos objetivos. E esse arranjo é rotulado como firma por conveniência (SUNDER, 1997a). 
A contabilidade ajuda a implementar e reforçar contratos que constituem a firma, e desempenha cinco funções para viabilizar o funcionamento da firma:

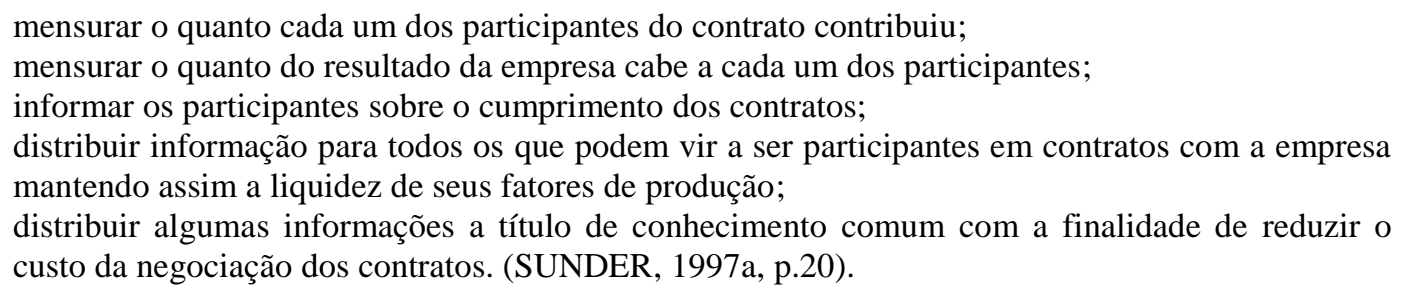

Princípios, normas e convenções contábeis podem ser vistos sob a ótica contratual. Alguns parâmetros e condições gerais podem ser definidos para que não seja necessário elaborar uma análise específica de cada contrato, minimizando, assim, o custo de manter tais contratos. No direito, essa definição se dá por meio dos princípios básicos, como seria o caso de que nenhum contrato pode estabelecer uma relação de trabalho escravo no Brasil. $\mathrm{Na}$ contabilidade, essa definição também ocorre. Quando uma empresa apresenta seu resultado, parte-se da premissa de que esse resultado apresentado é conservador, tendo como consequência a impossibilidade de distribuição de dividendos sobre resultados não existentes, evitando a descapitalização e eventualmente a insolvência da empresa (LOPES, 2004).

A contabilidade faz os contratos funcionarem. Afeta os agentes e é uma questão de negociação e barganha entre eles. $\mathrm{O}$ tipo de contrato que vincula cada agente à firma depende das características e recursos que o agente fornece e recebe, e determina o interesse em vários aspectos da contabilidade da firma (SUNDER, 1997a).

Cada organização desenvolve um sistema de informações contábeis ajustado às suas características únicas de forma que a contabilidade possa ser utilizada como um instrumento efetivo de controle. Em firmas pequenas, a função de controle é atendida pela escrituração contábil mais simples, enquanto em firmas grandes, com um grau maior de descentralização, necessitam de uma modalidade contábil mais complexa, chegando ao ponto de se contratar auditores para certificarem as informações fornecidas pelos gestores, (SUNDER, 1997b).

A contabilidade assume o papel de reunir, implementar, compelir, modificar e manter o conjunto de contratos estabelecidos. Pela contabilidade aqueles que estabelecem contratos com a firma podem avaliar suas escolhas, verificar se aquilo que estão recebendo dessa firma é compatível com o que estão oferecendo a ela. Os agentes são racionais no sentido de que 
não escolherão de forma consciente uma relação ou contrato, que não traga um benefício superior ao seu custo de oportunidade, o que significa que procuram ganhar com essa relação contratual. O conjunto de agentes compondo um conjunto de contratos, e cada um deles buscando atingir suas próprias metas, formam uma firma. Uma companhia não sobrevive se a soma dos benefícios que oferece aos agentes com os quais se relaciona for inferior ao custo de oportunidade que esses agentes possuem ao contratar com ela. Uma situação, assim, fará com que os agentes parem de estabelecer contratos com a companhia, inviabilizando, dessa maneira, sua existência (informação oral). ${ }^{1}$

A mudança de normas contábeis, porém, pode estar afetando essa relação contratual entre as partes. Especificamente no caso da utilização de informações contábeis na determinação de crédito em casos de empréstimos, Demerjian (2011) afirma que os covenants utilizando a contabilidade como métrica têm sido menos utilizados nessas transações supostamente devido à utilização mais intensa do valor justo na contabilidade das empresas, uma vez que a normatização tem se direcionado mais à avaliação de ativos e obrigações, e acordos de dívidas baseiam-se em informações contábeis conservadoras, com altos padrões de verificabilidade, para refletir o limite inferior de liquidação dos ativos líquidos.

No cenário brasileiro houve aumento na qualidade da informação contábil e uma redução no custo de capital próprio após a adoção completa das IFRS aponta estudo elaborado por Silva (2013). A contabilidade viabiliza a troca de informações entre agentes e empresa. Os agentes, por sua vez, têm possibilidade de avaliar a situação de seus contratos com essa empresa. Se os agentes forem acionistas, provavelmente estarão interessados na lucratividade e na distribuição de dividendos. Se forem credores, a análise deter-se-á sobre a capacidade da empresa em saldar suas obrigações. Se for o governo, na figura de sujeito ativo das obrigações tributárias, provavelmente haverá uma concentração em questões relacionadas a fatos geradores de tributos, como o lucro, que seria o ponto de partida para a apuração de imposto de renda e de contribuição social em muitos casos. Se forem docentes de contabilidade, como é o caso do público alvo do presente estudo, utilizam a contabilidade como material de

\footnotetext{
${ }^{1}$ Informação oral obtida em evento realizado na FEA USP: palestra "Contract Theory of Organizations, Accounting and Control" ministrada pelo Prof. Dr. Shyam Sunder, docente da Yale University (Estados Unidos da América), em 12 de março de 2013.
} 
trabalho para introduzir seus alunos na esfera profissional, na qual atuarão como usuários das informações contábeis assim como estarão aptos a elaborá-las.

\subsection{Informação contábil}

A necessidade dos usuários determina a forma como a contabilidade se apresenta. A contabilidade nasceu gerencial e não era normatizada. Sua normatização iniciou-se na Europa Continental, nos países latinos e germânicos, para atender ao interesse dos credores, com característica de ser muito conservadora, com o máximo de avaliação para os passivos e o mínimo para os ativos, e esse conservadorismo foi mais exagerado principalmente entre os germânicos, inclusive em detrimento do regime de competência. Na Inglaterra, a normatização contábil surgiu para atender aos credores e aos investidores igualmente, seguindo a filosofia de que boa contabilidade era a que produzia boas informações para os gestores das empresas, e essa posição permaneceu até a Revolução Industrial, período no qual a necessidade de recursos começa a aumentar para suportar a construção de grandes indústrias. Na Inglaterra e nos países sob sua influência esses recursos eram captados por meio de emissão de ações, e recorriam-se menos aos empréstimos bancários que os países da Europa Continental. Nesses locais, a boa contabilidade não era exageradamente conservadora, e passou a ser aquela que fornecesse aos investidores em ações as melhores informações para que decidissem sobre seus investimentos e também a que pudesse levar até esses investidores as melhores prestações de contas. No entanto, nos países latinos, privilegiou-se o Fisco durante o processo de normatização contábil (MARTINS et al., 2012).

Passados tantos anos do início da normatização contábil, o cenário parece fazer um movimento inverso àquele no qual se iniciou a normatização, ao estabelecer uma malha normativa a ser respeitada por diversos países, harmonizando, dessa forma, conceitos, objetivos, procedimentos. No início um panorama com um padrão contábil relativamente concentrado, que passou a dar espaço a padrões mais diversos em função do meio social no qual a contabilidade estava inserida, com mais ênfase ao atendimento a determinados usuários contábeis em detrimento de outros. Locais que passaram a privilegiar na elaboração das demonstrações os credores, enquanto outros locais privilegiavam os fornecedores de capital, e outros ainda com enfoque ao fisco. Nos dias atuais, com um número crescente de países adotando as normais internacionais de contabilidade, a diversidade de padrões contábeis tende a se reduzir. 
A contabilidade é um dos meios de condução de informações relevantes, uma vez que tem por objetivo fornecer dados úteis para a tomada de decisão. Esse objetivo, atualmente tido como consenso, já está assim definido há décadas. Como evidência da longevidade dessa existência, é possível citar o Relatório Trueblood, assim denominado por ter sido dirigido por Robert Martin Trueblood, apresentado, em 1973, como resultado do grupo de estudos sobre objetivos das demonstrações financeiras. O relatório desse grupo de trabalho foi resultado de consultas feitas a: acadêmicos de Contabilidade; contadores; consultores contábeis; mais de 5.000 empresas; patrocínio de mais de 50 reuniões; 35 debates com grupos interessados e promoção de três dias de audiência pública em New York. A conclusão do comitê foi de que o objetivo básico dos relatórios financeiros é o de fornecer informações úteis para a tomada de decisões econômicas (SCHMIDT; SANTOS, 2008).

Os órgãos responsáveis pela emissão de pronunciamentos contábeis recomendam que as firmas produzam informações que atendam ao maior número possível de usuários, assim como o Pronunciamento da Estrutura Conceitual da Contabilidade, emanado do CPC, sugere no Brasil (ALMEIDA, José, 2010).

A contabilidade pode ser caracterizada como um processo, chamado de processo contábil. Nesse processo há três etapas, que são o reconhecimento, a mensuração e a evidenciação. Assim responde às demandas do ambiente em sua complexidade. O processo contábil, então, é uma forma de interpretar e retratar a realidade, e sofre influência de um amplo conjunto de forças sociais e econômicas, dentre elas o Direito. O papel da contabilidade consiste em fornecer informações para que os usuários possam inferir os fluxos de caixa futuros das empresas analisadas, possuindo, dessa maneira, uma função eminentemente preditiva (LOPES; MOSQUERA, 2010).

Esse processo contábil tem como resultado as demonstrações contábeis, que tem por objetivo a apresentação simplificada da realidade (MARTINS, 2010). As demonstrações contábeis são excelentes ferramentas para visões prospectivas da atividade empresarial, embora por décadas, se não séculos, foi difundida a falsa percepção de que são retratos do passado. Não se pode negar o papel da informação de caráter histórico, mas não é esse o único destino da informação contábil, nem sua missão mais nobre. O principal papel dessas demonstrações no mundo corporativo é informar sobre o futuro esperado à luz do passado realizado. Para uma informação do mundo das finanças corporativas ser capturada e comunicada pelo modelo 
contábil que a ciência e o mundo desenvolvido propõem, deve ser relevante, confiável, ter fidelidade representacional e ter valor preditivo, e esta última condição depende da prevalência da essência sobre a forma (CARVALHO, 2010).

Quanto mais informações são fornecidas aos usuários da contabilidade, mais elas são utilizadas, porém os termos técnicos, teóricos e conceituais dificultam essa comunicação (LOPES et al., 2009).

Os usuários, pelos resultados de uma empresa e que não participam de sua gestão, dependem de uma informação contábil com qualidade para a redução da assimetria informacional existente entre eles e o negócio. A adoção de práticas de governança corporativa e uma visão sistêmica e dimensional do controle organizacional são mecanismos minimizadores de possíveis riscos de distorções das informações (NASCIMENTO; REGINATO, 2008).

Nessa mesma linha de raciocínio, Lima (2009) demonstrou que empresas com maior nível de disclosure apresentam uma relação inversa com o custo de capital de terceiros.

No Brasil, a contabilidade privilegia dados contábeis, como o patrimônio líquido e os lucros anormais (acréscimos ao patrimônio), pois suas empresas dependem de crédito bancário para desenvolverem suas atividades, em decorrência do modelo continental no qual está amparada (GUIMARÃES, 2010).

As normas internacionais de contabilidade passaram a ser utilizadas obrigatoriamente na União Europeia a partir de 2005, nas demonstrações contábeis consolidadas. No intuito de verificar se a adoção dessas normas produziu algum impacto significativo em um determinado grupo específico de demonstrações contábeis, Miranda (2008) estudou a diferença entre indicadores de instituições financeiras de três países: Reino Unido, França e Espanha. Nesse estudo foi comparada a prática local com a prática decorrente da adoção das IFRSs. Os indicadores utilizados foram: liquidez imediata, alavancagem e capitalização. A conclusão foi de que houve diferença significativa entre os indicadores de bancos de alguns países da União Europeia, considerando-se as práticas locais e as práticas segundo as IFRSs. 
As alterações ocorridas nas práticas contábeis nos últimos anos buscam atender à necessidade do mercado, no tocante à exigência de maior confiabilidade e maior qualidade das informações contábeis divulgadas pelas empresas (GERON, 2008).

Com a aceleração do processo de internacionalização dos mercados e a expansão dos mercados de capitais, os investidores internacionais, analistas, banqueiros e demais usuários da informação contábil têm aumentado sua exigência sobre a contabilidade, para que possam analisar melhor as demonstrações contábeis das companhias transnacionais. O aumento de fusões e aquisições também tem gerado o mesmo efeito (CAMBRIA, 2008).

Em pesquisa nas companhias abertas brasileiras listadas na Bolsa de Valores de São Paulo e também nas companhias abertas norte-americanas listas em bolsas de valores naquele país, Benetti (2011) concluiu ser esperado um acréscimo na qualidade da informação contábil, assim como na sua comparabilidade em decorrência da adoção das normas internacionais de contabilidade. Expôs a maior dificuldade dos auditores com relação aos analistas entenderem as IFRSs. Relatou, ainda, que na opinião de gestores, auditores e analistas a adoção dos IFRSs melhorou a proteção dos investidores. Ressaltou que, por outro lado, a adoção dos IFRSs parece ter um custo alto devido à reorganização dos sistemas de informação, ao reprocessamento de informações disponíveis e ao treinamento necessário.

A utilização de normas internacionais de contabilidade teve consequências significantes e positivas para o desenvolvimento do mercado de capitais, revelou estudo com amostra de 38 países em desenvolvimento. A utilização dos padrões do IASB direcionou para a melhoria de qualidade da informação contábil informada por companhias abertas, assim como da motivação por parte dos investidores em realizar mais transações (ZEGHAL; MHEDHBI, 2012).

As demonstrações contábeis de acordo com o CPC 13, resultantes do primeiro passo rumo à adoção de novas normas contábeis alinhadas mundialmente, revelaram novas informações ao mercado, e essas informações foram oportunas, tomando-se por base as demonstrações contábeis das empresas pertencentes ao IBrX-100 da BM\&FBovespa, representando, desse modo, as empresas com ações mais líquidas (SILVA; LOPES, 2012). 
Após a adoção de normas internacionais, em estudo baseado nas demonstrações contábeis de 2007 e 2010 de 74 empresas pertencentes a cinco setores econômicos - telecomunicações, petróleo, gás, mineração, alimentos e energia elétrica - apontou aumento significativo no quantitativo de políticas contábeis apresentadas em notas explicativas, observando-se maior evidenciação de informações que auxiliem os usuários a compreender a forma de preparação das informações publicadas (SOUZA et al., 2012).

A adoção voluntária dos padrões internacionais de contabilidade pode ter como resultado um maior número de analistas acompanhando as informações da empresa, assim como uma significativa redução do custo de capital. Os autores ressaltam, no entanto, que esse estudo, que considerou 1072 empresas no período entre 1988 e 2002, somente relatou possibilidades relacionadas à adoção voluntária dos padrões internacionais de contabilidade, não se aplicando às adoções compulsórias (KARAMANOU; NISHIOTIS, 2009).

Vieira (2010) apresentou indícios de que houve aumento de qualidade das informações contábeis com a adoção das novas normas contábeis no Brasil, a partir de 2008, mesmo considerado que o período destacado para que o estudo fosse elaborado compreendesse o período de transição, entre normas vigentes anteriormente e as atuais. $\mathrm{O}$ autor sugeriu que possivelmente respostas mais reveladoras seriam obtidas quando da adoção completa dos IFRSs.

A busca pelo aumento de qualidade das informações é sempre desejável e encontra um obstáculo que é a subjetividade. À medida que uma informação se desprende da objetividade, tem potencial para ser mais útil, mas também traz consigo uma dose de incerteza decorrente da aplicação da subjetividade. Avaliar uma propriedade para investimento pelo valor de custo ou pelo valor justo? Pelas normas contábeis vigentes, as duas formas de mensuração podem figurar nas demonstrações contábeis, o que pode prejudicar a comparabilidade dessas demonstrações.

Quando se encontra em um balanço, no grupo investimentos, um valor de propriedade para investimento mensurado pelo custo histórico, há pouca dúvida com relação à sua procedência e confiabilidade, ainda que sua utilidade possa ser questionada por decorrência da defasagem desse custo histórico com relação ao efetivo valor econômico que esse imóvel tem. 
Por outro lado, ao deparar com o valor de uma propriedade para investimento no balanço de uma empresa avaliada pelo valor justo no grupo investimentos, a informação apresentada é potencialmente mais útil do que aquela apresentada pelo custo histórico. Ela pode contemplar os efeitos da inflação, assim como da valorização ou desvalorização imobiliária sofrida pela propriedade. No entanto, não há como ter certeza, nesse caso, que haveria somente um número possível. Depende da visão de quem avaliou, do método que foi utilizado na avaliação, de taxas que foram aplicadas, o que imprimiria às demonstrações contábeis certo grau de incerteza, derivado da subjetividade envolvida.

Esse parece ser o dilema: ficar com uma informação objetiva e possivelmente pouco útil, ou com uma informação subjetiva e potencialmente mais útil. Pelo desenvolvimento das normas contábeis, é possível afirmar que a escolha recai sobre a segunda opção.

\subsubsection{A informação contábil com utilização de indicadores}

Os indicadores permitem a apresentação de forma sintetizada de informações aos usuários da informação contábil. Abordar a questão dos indicadores tem relação com o presente estudo pelo fato do patrimônio líquido, seu objeto, estar relacionado diretamente à boa parte desses índices.

Nos primórdios das análises de informações contábeis com utilização de indicadores, bancos fornecedores de crédito, por meio de sua organização - Robert Morris Associates - realizaram trabalho útil colecionando estatísticas classificadas por tipos de negócio e registrando índices médios de vários tipos, e esses índices médios ficavam disponíveis aos bancos como padrões dos segmentos (LITTLETON; ZIMMERMAN, 1962).

$\mathrm{Na}$ análise de balanços, a observação dos fatos econômico-financeiro-patrimoniais das empresas seguidos da decomposição nos seus componentes, do estudo individual de cada componente, das relações entre os componentes e das relações como todo, permitem a extração das informações desejadas (LYRA, 2008).

Martins et al (2012) ponderam que ao analisar um balanço resumidamente se pretende conhecer dois principais pontos de uma empresa: sua rentabilidade e sua liquidez, e esses dois pontos são conflitantes, já que o máximo da liquidez se consegue com muito recurso financeiro disponível para saldar dívidas, e dessa forma a rentabilidade é diminuída. 
Na visão de Palepu et al (2004), o objetivo da análise financeira é avaliar a performance de uma firma no contexto de seus objetivos e estratégia declarados. Os autores definem como ponto de partida para uma análise sistemática do desempenho de uma empresa o retorno sobre o investimento (do inglês Return on Equity ROE), definido como lucro líquido/patrimônio líquido. O ROE é um indicador abrangente do desempenho de uma empresa porque proporciona uma indicação de como os gestores estão investindo os recursos disponibilizados pelos investidores com o objetivo de gerar retornos. Os autores explicam ainda que o valor do investimento em uma firma é determinado pela relação entre o ROE e seu custo de capital. Dessa maneira, firmas que proporcionam ROE acima de seu custo de capital deveriam ter valor de mercado acima de seus valores registrados na contabilidade (book value), e o contrário também é verdadeiro. Essa comparação entre ROE e custo de capital não é útil somente para se contemplar o valor da firma, mas também para se considerar o caminho da rentabilidade futura. A geração de lucros anormais consistentes atrairá competição para o mercado, na ausência da existência de barreiras de mercado. Sendo assim, o ROE tende a ser levado para um patamar "normal", que seria próximo ao custo de capital da firma. Desvios além desse nível são ocasionados por duas razões: condições e estratégia competitiva que levam a empresa a gerar lucros anormais, acima ou abaixo de seu custo de capital, ou, então, distorções decorrentes da contabilidade.

Ao analisar o uso de medidas de desempenho de empresas presentes na pesquisa em contabilidade no Brasil, Girioli (2010) identificou 237 variáveis utilizadas na literatura contábil como proxies da mensuração de desempenho. Dessas, a maioria $(62,44 \%)$ aparece uma única vez no universo de todos os trabalhos pesquisados, evidenciando a frequente criação de medidas de desempenho pelos autores.

Galdi (2008) demonstrou que mesmo com características específicas e com regime contábil específico, as estratégias de investimento com base em informações contábeis são úteis na seleção de carteiras que gerem retornos anormais significativos, ainda que a análise de balanços possa ser utilizada para outros fins, como análise de performance, avaliação de crédito, análise de liquidez e rentabilidade, entre outras não citadas no referido estudo.

Neto et al (2009), por meio de estudo realizado com oito empresas, constataram haver diferenças entre indicadores contábeis calculados com base em padrões contábeis brasileiros existentes antes do processo de convergência e indicadores contábeis calculados com base nas 
IFRSs, e, apesar da diferença entre esses indicadores, concluiu-se não haver diferença estatisticamente significativa entre eles. Com relação a esse estudo é necessário ponderar o fato de ter sido realizado no início do processo de convergência, tendo, assim, poucas empresas a serem analisadas.

Nunes (2010), com base no ISE - Índice de Sustentabilidade Empresarial, assumindo que empresas pertencentes esse índice fossem sustentáveis, e por exclusão, empresas semelhantes não pertencentes ao índice não seriam, realizou estudo na tentativa de identificar diferenças significativas entre indicadores contábeis entre esses dois grupos. $\mathrm{O}$ estudo teve como foco dois segmentos, o de energia elétrica e o bancário. A conclusão foi de que no setor de energia não foi possível identificar diferenças significativas nos índices de risco e de retorno entre os dois conjuntos de empresas. No setor bancário, não foram encontradas diferenças significativas nos indicadores relacionados a risco, e a análise de indicadores de rentabilidade demonstrou-se inconclusiva. Estudando-se empresas sem segregá-las por setores, não foram encontradas diferenças significativas entre indicadores de risco e de retorno entre empresas pertencentes e não pertencentes ao índice ISE.

Relacionado ao fato de fazer parte ou não do ISE, Guimarães (2010) concluiu, da mesma forma, ao verificar não ter havido ganho de valor de empresas participantes desse índice no período de 2005 a 2009.

Com relação ao grau de importância de indicadores, avaliado por especialistas, o índice de rentabilidade sobre o PL é o que aparece com maior número relativo de respostas descrevendo-o como "muito importante", conforme apontado pela pesquisa de Lyra (2008, p.89). Na tabela 4 apresentam-se os resultados obtidos no referido estudo: 
Tabela 4- Grau de importância dos indicadores pelos especialistas

\begin{tabular}{lcccc}
\hline & $\begin{array}{c}\text { Muito } \\
\text { importante }\end{array}$ & $\begin{array}{c}\text { Importante } \\
\text { Rentabilidade do PL }\end{array}$ & $\begin{array}{c}\text { Pouco } \\
\text { importante }\end{array}$ & Irrelevante \\
\hline Crescimento das vendas & $\mathbf{6 2 \%}$ & $\mathbf{3 8 \%}$ & - & - \\
\hline Margem liquida & $54 \%$ & $38 \%$ & $8 \%$ & - \\
\hline Rentabilidade do ativo & $\mathbf{5 4 \%}$ & $\mathbf{3 8 \%}$ & $\mathbf{8 \%}$ & - \\
\hline Endividamento Geral & $54 \%$ & $30 \%$ & $16 \%$ & - \\
\hline Liquidez Corrente & $\mathbf{4 6 \%}$ & $\mathbf{4 6 \%}$ & $\mathbf{8 \%}$ & - \\
\hline Giro do ativo & $38 \%$ & $62 \%$ & - & - \\
\hline Investimento no Imobilizado & $\mathbf{3 1 \%}$ & $\mathbf{6 2 \%}$ & $\mathbf{7 \%}$ & - \\
\hline Grau de alavancagem operacional & $31 \%$ & $31 \%$ & $38 \%$ & - \\
\hline Imobilização do PL & $\mathbf{1 5 \%}$ & $\mathbf{6 2 \%}$ & $\mathbf{2 3 \%}$ & - \\
\hline Liderança de mercado & $15 \%$ & $46 \%$ & $38 \%$ & - \\
\hline Liquidez Geral & $\mathbf{8 \%}$ & $\mathbf{5 4 \%}$ & $\mathbf{2 3 \%}$ & $\mathbf{1 5 \%}$ \\
\hline Tamanho da empresa & - & $69 \%$ & $31 \%$ & - \\
\hline Riqueza criada por empregado & - & $\mathbf{3 8 \%}$ & $\mathbf{3 8 \%}$ & $\mathbf{2 4 \%}$ \\
\hline
\end{tabular}

Fonte: Lyra, 2008, p.90

O índice de rentabilidade sobre o PL foi também o indicador mais bem conceituado como avaliador de desempenho das empresas (LYRA, 2008). O indicador rentabilidade sobre o patrimônio líquido foi apontado também como o principal indicador de avaliação de desempenho empresarial (LYRA, 2008).

Analisando índices de rentabilidade de instituições financeiras, no período de 1997 a 2004, Gregório (2005) reconheceu que o setor bancário privado atuante no Brasil naquela época tinha apresentado rentabilidade sobre o patrimônio líquido maior do que os setores privados não financeiros. Não obstante, essa rentabilidade como um todo não tinha sido, em média, suficiente para cobrir o custo de capital próprio de tais instituições, resultando na incapacidade de gerar valor para os acionistas nesses casos.

Ao estudar a rentabilidade bancária com relação a tamanho, origem de capital e operações de crédito, Oliveira (2008) concluiu que ela pode variar. A rentabilidade mostrou-se não uniforme em relação ao nível de operação de crédito em dois períodos e também não uniforme em relação à origem de capital em três períodos. Dessa forma, ao se observar o segmento bancário sem levar em consideração tais observações corre-se o risco de adotar uma visão simplista da realidade.

A estrutura de capital das empresas tem sido objeto de estudos no sentido de explicar o mix de fontes de financiamento utilizado pelas empresas, e as teorias abordam aspectos distintos, uma vez que há alternativas, e cada uma, com seus custos e benefícios (ALBANEZ, 2008). 
Myers (1984) afirma haver um desconhecimento sobre como as empresas fazem escolhas sobre a opção de se financiar por meio de dívidas, capital próprio ou títulos híbridos. Consolidando sua opinião, declara anos depois que não há uma teoria universal sobre a escolha da estrutura de financiamento das empresas, e não há motivos para esperar que exista uma (MYERS, 2001).

Analisando-se a estrutura de capital das empresas, Forte (2007) afirma, como parte do resultado de sua pesquisa, que no cenário brasileiro empresas de maior porte têm acessos diferenciados em relação à escolha da estrutura de capital, quando comparadas com empresas menores. Uma vez que o risco se apresenta correlacionado positivamente com o endividamento, possivelmente há influência da redução de elementos de assimetria de informação, em linha com a teoria de agência. Ficou demonstrado que a estrutura de capital das empresas brasileiras de capital aberto obedece a um modelo dinâmico de ajustamento, não se apresentando de maneira estática, o que poderia ser compreendido no ambiente macroeconômico brasileiro de altas taxas reais de juros, em que necessidades de caixa gerariam significativos impactos nas variáveis financeiras das empresas, evidenciando um comportamento conservador por parte dos executivos. A velocidade desse ajustamento se apresentou baixa, fator que poderia ser explicado pelos altos spreads bancários acarretando custos elevados em eventuais mudanças de posição financeira, além da pouca diversidade de opções de financiamentos diretos com agentes privados que não sejam bancos. Conclui-se também que os gestores priorizam a liquidez, em detrimento do investimento em inovações e tecnologia, atividades de maior risco e prazo de maturação.

Harris e Raviv (1991) identificaram quatro categorias de determinantes da estrutura de capital que se baseiam no custo de agência, na assimetria da informação, interação de mercados de produtos e insumos, e baseados na competição por controle corporativo.

A forma de financiamento das empresas tem forte influência das práticas de governança no Brasil, decorrentes do ambiente legal. A geração própria de caixa representa a principal fonte de recursos das empresas, e esse padrão diferenciado é explicado, em parte, pela estrutura de controle e propriedade existente no Brasil (LEAL; SAITO, 2003).

Ao analisar estruturas de financiamentos de companhias abertas brasileiras, no período de 1995 a 2000, Perobelli e Famá (2002) concluíram que, para certos tipos de empresas, a 
emissão de dívida é muito mais viável do que a emissão de ações. Empresas com alto potencial de crescimento e empresas que detêm alto volume de ativos intangíveis ou comercializam produtos altamente especializados enfrentariam custos menores promovendo emissões de ações. Por outro lado, empresas que são lucrativas e que enfrentam baixos custos de agência do capital próprio deveriam financiar seus projetos com a utilização de lucros retidos. Empresas com baixo potencial de crescimento têm seu valor aumentado com o endividamento, enquanto ocorre o contrário em empresas com alto potencial de crescimento, o que explicaria os baixos níveis de endividamento encontrados nessas empresas.

O tamanho da empresa, também, foi identificado como relevante na estrutura de endividamento das empresas. Nakamura et al (2007), ao investigarem a estrutura de capital de companhias abertas, concluíram que o tamanho e o crescimento das empresas têm uma relação positiva com o endividamento, enquanto rentabilidade e expectativa externa de crescimento têm uma relação negativa com a alavancagem.

Com base no estudo da estrutura de capital das 500 maiores empresas do país, no período de 1998 a 2002, Brito, Corrar e Batistella (2007) inferem que as empresas se endividam mais com recursos de curto prazo do que com recursos de longo prazo. Os autores assimilam que as variáveis que mais contribuem para a explicação do endividamento das empresas são risco e composição dos ativos, as variáveis tamanho e crescimento são relevantes na explicação do endividamento de longo prazo, não o sendo com relação ao endividamento de curto prazo, e as variáveis tipo de capital e rentabilidade não foram percebidas como significativas na explicação do endividamento das empresas de acordo com o estudo.

Formigoni (2008) realizou estudo sobre o efeito de incentivos fiscais na estrutura de capital e na rentabilidade de companhias abertas brasileiras não financeiras, no qual conclui que há evidências de que a rentabilidade do ativo e do patrimônio líquido tendem a aumentar nas companhias abertas que se utilizam de benefícios fiscais, influenciando, assim, seu desempenho. O autor não identificou correlação estatisticamente significativa entre incentivo fiscal e os indicadores de endividamento das empresas. Importante ressaltar que o estudo retrata o cenário de uma época na qual o incentivo fiscal ainda não transitava pelo resultado (DRE), e era lançado diretamente no patrimônio líquido das empresas. 
Albanez (2008) estudou companhias abertas, no período de 1997 a 2007, com o objetivo de analisar se a informação assimétrica constitui um componente importante na estrutura de capital dessas companhias. Obteve resultados que permitem pensar que empresas com menor assimetria de informação poderiam ter maior acesso a mercados em que a sensibilidade à informação é maior, como mercado de capitais de dívidas de longo prazo e ações. Isso possibilitaria a redução do endividamento de curto prazo e diminuiria a possibilidade de serem emitidas ações com underpricing.

Albanez e Valle (2009), ao estudarem a estrutura de capital das empresas de capital aberto no período de 1997 a 2007, concluíram que empresas com menor assimetria informacional são menos endividadas, por terem a oportunidade de captar recursos com emissão de títulos patrimoniais, devido à baixa probabilidade de ocorrência dos problemas derivados da assimetria da informação, como seleção adversa, e sua consequência, a queda no preço da ação após um anúncio de emissão.

Empresas com melhores práticas de governança corporativa apresentam menor endividamento, de acordo com o estudo de Cândido (2010). Essa conclusão pode decorrer da hipótese de que empresas com melhor nível de governança corporativa podem recorrer com mais facilidade ao mercado acionário para captar recursos, ambiente no qual há uma assimetria informacional maior. Por meio dessa captação de recursos no mercado acionário, o gestor pode pautar a distribuição de recursos, em função da maior discricionariedade existente na distribuição de dividendos com relação ao pagamento de juros.

Soares (2006) analisou se os indicadores escolhidos pela Agência Nacional de Saúde - ANS para compor seu indicador de qualificação seriam os mais relevantes e concluiu de forma positiva, reafirmando os critérios de seleção da ANS, além de certificar o nível de transparência das informações de tal órgão, uma vez que as informações necessárias para a análise foram obtidas a partir de informações disponibilizadas ao público.

Silveira, Perobelli e Barros (2008), na mesma linha, sugerem que o grau de alavancagem financeira das empresas é significativamente influenciado por suas práticas de governança, nesse estudo captadas por quatro dimensões: acesso às informações, conteúdo das informações, estrutura do conselho de administração e estrutura de propriedade e controle. 
Indicadores contábeis podem, também, identificar se houve ou não violação de um determinado covenant, como pelo uso de índices de rentabilidade ou estrutura de capital. Em estudo realizado com 125 empresas com títulos patrimoniais negociados na Bolsa de Valores de São Paulo, no período de 2000 a 2006, foi evidenciado que as empresas não efetuam mudanças de práticas contábeis voluntárias com o objetivo de violar o cumprimento de covenants contábeis, e essas mudanças quando são voluntárias, geralmente implicam aumento do resultado e do patrimônio líquido no período, ao contrário das mudanças obrigatórias, que geralmente implicam redução do resultado e do patrimônio líquido do período (SILVA, 2008).

Schvirk (2006) abordou o comportamento de indicadores contábeis quando da existência de reavaliação de imobilizado, figura atualmente proibida pela contabilidade nacional. Concluiu que todos os indicadores são afetados por tal procedimento, uns mais, outros menos. Observou, também, que a melhora dos indicadores aumenta com o aumento da dependência do capital de terceiros, fazendo com que empresas mais endividadas desfrutem de um maior benefício pela prática da reavaliação de ativos. Ao se expurgar o efeito da reavaliação das demonstrações contábeis, os indicadores mais afetados foram o endividamento total, a composição do endividamento, a liquidez geral e a margem líquida. O autor assevera, ainda, que o endividamento é o principal fator apontado pela literatura que motiva a prática de reavaliar ativos imobilizados, isso porque o patrimônio líquido é aumentado pelo valor da reavaliação, aparentando uma menor dependência de capital de terceiros.

Com relação ao EBITDA, Alcade (2010) revelou, por intermédio de um estudo utilizando o método de HLM - Hierarchical Linear Modeling, que ao contrário do que o senso comum poderia indicar, há variabilidade maior entre indicadores de empresas do mesmo segmento do que entre indicadores de segmentos diferentes. Essa conclusão pode auxiliar na utilização ou não de tal indicador como forma de comparar empresas do mesmo setor.

Os indicadores econômico-financeiros têm uma relação estatisticamente significante com operações de títulos e valores mobiliários no setor bancário. Essa relação está presente quando se trata dos indicadores de liquidez, estrutura patrimonial, estrutura de aplicação, estrutura de captação e participação de despesas sobre receitas operacionais. Os dados constam em estudo envolvendo 10 semestres de 104 instituições financeiras (OLIVEIRA, 2011). 
Amorim (2010) na tentativa de identificar existência de significância estatística entre betas de mercado e determinados betas contábeis, não a encontrou para a maioria dos betas contábeis (proxies) estudados. No caso de alguns betas contábeis, apesar de não terem apresentado coeficientes de correlação que não fossem elevados, cerca de 30\%, houve associação, em algum grau entre os betas e as variáveis contábeis com os betas de mercado. As variáveis que obtiveram uma maior correlação com betas de mercado foram: variação percentual do indicador market to book, total de capital de terceiros sobre o patrimônio líquido, lucro antes do imposto de renda sobre o ativo total, grau de alavancagem operacional, grau de alavancagem financeira e o beta contábil do indicador financeiro de liquidez.

Os indicadores relacionados à rentabilidade e à estrutura de capital mostram-se relevantes no desenvolvimento de estudos acadêmicos. O patrimônio líquido está diretamente ligado a tais indicadores por fazer parte da estrutura de capital e muitas vezes do cálculo do retorno dos investidores. $\mathrm{Na}$ medida em que o presente estudo aborda alterações no patrimônio líquido, acaba por se relacionar também com indicadores contábeis, pois alterações no patrimônio líquido resultam em alterações dos referidos indicadores.

Os indicadores contábeis apresentam uma visão geral da situação da empresa. Contudo, não podem ser encarados como exatos ou como a única fonte de informação sobre as empresas. As empresas, por vezes, têm formas de contabilização alternativas, situações nas quais podem escolher como mensurar itens patrimoniais, o que traz como consequência uma certa perda de comparabilidade. A própria subjetividade cada vez mais presente na contabilidade nacional faz com que a análise de demonstrações contábeis por meio de indicadores represente mais um conjunto de indícios do que uma prova irrefutável das situações individuais das empresas, o que não prejudica a utilidade atribuída a eles, apenas insere certas ponderações acerca da utilização.

\subsection{Comparabilidade de demonstrações contábeis}

A comparabilidade de demonstrações contábeis é tida como um argumento favorável a um conjunto unificado internacionalmente de normas contábeis. Dentre os argumentos podem ser apresentados a facilidade de comparação de empresas sediadas em diferentes países, a redução de custo de captação nos mercados financeiros e a maior transparência das atividades empresariais (LOPES; MOSQUERA, 2010). 
O IASB define comparabilidade como a característica qualitativa que permite aos usuários identificar e entender similaridades e diferenças entre itens. Essa característica não está relacionada a um único item. Uma comparação requer ao menos dois itens. Consistência, apesar de relacionada à comparabilidade, não é a mesma coisa. Comparabilidade é o objetivo, e consistência ajuda a atingir esse objetivo. Apesar de eventos econômicos poderem ser representados fielmente de várias formas, ao se permitir práticas alternativas de um mesmo fenômeno econômico reduz a comparabilidade (IFRS FOUNDATION, 2010).

A comparabilidade, a redução de custos e a globalização econômica são objetivos importantíssimos favorecidos pela pressão para a internacionalização das normas contábeis (IUDÍCIBUS, 2010).

Se os números apresentados pela contabilidade são mensurados e demonstrados de maneira diferente, os indicadores financeiros também não são comparáveis de um país para outro. Caso regras e padrões contábeis nacionais não vão ao encontro das necessidades das comunidades financeiras e de negócios internacionais, então, padrões contábeis internacionais podem ser a resposta. A necessidade por padrões de contabilidade internacionais é particularmente intensa em corporações internacionais que precisam satisfazer muitos requisitos simultaneamente em cada país em que operam (CHOI; MUELLER, 1992).

O uso do mesmo método contábil por várias empresas não incrementa necessariamente a comparabilidade das demonstrações contábeis nem indica harmonia contábil no âmbito internacional. A escolha do método mais adequado, de acordo com parâmetros fixados internacionalmente pelas empresas de diferentes países que define a harmonização. Devem ser disponibilizados métodos contábeis alternativos para que cada empresa utilize o mais apropriado ao seu caso, respeitando suas condições operacionais (WEFFORT, 2005).

Em estudos nos quais o objetivo é mensurar a comparabilidade de números gerados pela mesma companhia sob diferentes regimes contábeis pode ser utilizado o Índice de Comparabilidade, também conhecido como índice de Gray. Inicialmente denominado índice de conservadorismo, foi renomeado posteriormente por Wetmann et al., em 1998, colocando clara ênfase no tratamento contábil relativo, sem exigir um julgamento do que é mais ou menos conservador (LEMES; CARVALHO, 2009). 
Lemes e Carvalho (2009) apresentaram resultados indicando que dentro de um conjunto de trinta empresas brasileiras, que publicaram demonstrações contábeis em padrões brasileiros em um período pré-convergência de normas, e também em padrão norte-americano, vinte e uma delas produziram números materialmente diferentes, demonstrando, assim, a dificuldade em se comparar demonstrações contábeis elaboradas sob mais de um conjunto de normas contábeis. Os autores concluíram, adicionalmente, que o lucro publicado segundo as normas brasileiras foi maior do que o lucro publicado segundo as normas norte-americanas, contrariando a crença de que empresas brasileiras são conservadoras no reconhecimento de suas receitas e suas despesas.

Expressões contidas nas normas contábeis que denotem incerteza podem apresentar diferenças na percepção sobre o que significam. As expressões "razoavelmente possível", "não se espera", "provável" e "altamente provável” foram identificadas por Sá e Malaquias (2012) como sendo termos que apresentaram diferenças na percepção de seus significados, e dessas, a expressão "provável” é a que mais se repete em quantidade nos pronunciamentos do CPC. Essas diferenças na percepção podem acarretar interpretações distintas de um mesmo evento, influenciando nas tomadas de decisões daqueles que elaboram demonstrações contábeis e também na comparabilidade entre as demonstrações contábeis, afirmam os autores ao elaborar esse estudo baseado em pronunciamentos referentes a instrumentos financeiros.

Empresas portuguesas apresentaram diferenças nos valores do balanço patrimonial e da demonstração de resultado e, também, nos indicadores econômicos, considerando-se informações antes e depois da adoção de normas com base nos IFRSs, e o estudo realizado levou a autora a concluir pela limitação de comparabilidade entre informações contábeis produzidas com base no Plano Oficial de Contabilidade - POC (padrão local) e as produzidas pelos demais países europeus com base no modelo normativo do IASB (ENCARNAÇÃO, 2009).

Avaliando-se a comparabilidade de informações contábeis entre empresas localizadas fora dos Estados Unidos e empresas norte-americanas que elaboraram demonstrações com utilização dos US GAAPs (princípios contábeis norte-americanos) percebeu-se uma maior comparabilidade quando aquelas se utilizaram de IFRS do que quando se utilizaram de padrões domésticos locais. Concluiu-se, ainda, que a comparabilidade se demonstrou ainda maior quando as empresas localizadas fora dos Estados Unidos adotaram IFRS de forma 
obrigatória, e estavam situadas em um ambiente jurídico baseado em common law e com alto enforcement (BARTH et al., 2012).

Defensores das normas baseadas em IFRS argumentam que um conjunto uniforme de normas melhora a comparabilidade de informações contábeis, e estudo realizado por Defond et al (2011) testou essa afirmação. Os autores esperavam que a adoção obrigatória das normas IFRS aumentaria o volume de investimentos entre empresas de países distintos, enquanto previam que tal adoção levaria a um aumento na comparabilidade somente se acompanhada por aumento crível na uniformidade. De forma consistente com as expectativas descobriram que a adoção obrigatória das normas IFRS resultaram em maior aumento em investimentos estrangeiros entre companhias em países com forte credibilidade na implantação que propiciam aumentos na uniformidade relativamente grandes.

$\mathrm{O}$ argumento de que a convergência para IFRS necessariamente aumenta comparabilidade de informações financeiras é contestado por Gordon e Gallery (2012) ao estudarem a contabilização de benefícios pós emprego. Os autores argumentam ser contestável tal afirmação pela dificuldade em medir e quantificar a comparabilidade, e por depender como primeira condição da informação ser relevante e fielmente retratada, e basear-se na aplicação do método escolhido de maneira consistente pelas empresas e no decorrer do tempo. Como resultado pode ser alcançada uma miragem de comparabilidade que passa a impressão de que eventos econômicos parecidos estão sendo contabilizados da mesma forma, e ressaltam as dificuldades dos órgãos reguladores com relação a questões que sofrem interferências decorrentes de jurisdições distintas nas quais a comparabilidade é adequada .

Analisando-se a comparabilidade entre demonstrações contábeis de empresas sediadas no Reino Unido e na Austrália, Cairns et al (2011) apresentaram resultados no sentido de que a partir da adoção dos IFRSs em 2005, nem sempre a comparabilidade entre demonstrações do mesmo e entre os países aumentou em decorrência da utilização do valor justo. Houve casos em que a utilização do valor justo aumentou a comparabilidade e a relevância da informação contábil entre empresas do mesmo país e entre os dois países: utilização obrigatória do valor justo em derivativos e pagamentos baseados em ações. A utilização do custo histórico e o abandono de práticas de reavaliação aumentaram a comparabilidade das demonstrações contábeis do mesmo país e entre os países. A opção de utilizar o valor justo reduziu a comparabilidade das demonstrações contábeis no caso dos instrumentos financeiros e 
obrigações financeiras. O estudo demonstrou, ainda, que as empresas desses dois países fizeram escolhas contábeis de forma similar.

\subsection{Conceito de patrimônio líquido: evolução histórica}

Os direitos dos proprietários são tradicionalmente divididos em duas categorias: capital investido e lucros retidos. Esses direitos têm natureza residual, o que significa que os proprietários somente receberão a parte que cabe a eles depois que os credores da empresa já tiverem recebido. Em geral, os acionistas não podem esperar a devolução de capital em datas definidas ou determináveis (HENDRIKSEN; VAN BREDA, 1999).

O patrimônio líquido reflete o montante que os sócios ou acionistas colocam à disposição da empresa para que ela exerça sua atividade, acrescido daquilo que poderia ter retirado dessa empresa e não foi, parcela comumente conhecida como lucros retidos. Percebe-se, assim, que o patrimônio líquido tem um vínculo indissolúvel com os sócios ou acionistas da empresa, retratando a propriedade. As principais teorias acerca do direito de propriedade são:

a) Teoria da propriedade: supõe-se que os ativos pertencem ao proprietário enquanto os passivos são obrigações do proprietário, já tendo sido considerado inclusive como ativos negativos. O patrimônio líquido representa a riqueza líquida do proprietário. Receitas e despesas são aumentos e diminuições, respectivamente, da riqueza do proprietário. Essa teoria se aplica com maior facilidade às empresas individuais e sociedades de pessoas, não se aplicando tão facilmente às sociedades por ações. O conceito de lucro abrangente adotado pelo Financial Accounting Standards Board (FASB), órgão norte-americano normatizador em matéria contábil, baseia-se na teoria da propriedade, por incluir todos os itens que afetam a propriedade durante o período, com exceção das retiradas de dividendos e transações de capital. Os ativos devem ser medidos em termos de valores correntes, pois se considera que o patrimônio dos proprietários é seu valor líquido (HENDRIKSEN; VAN BREDA, 1999).

Teoria apresentada inicialmente por Pacioli, na qual o proprietário é o centro das atenções. Todos os conceitos contábeis, procedimentos e regras são formulados com foco no interesse dos proprietários, e essa é uma realidade até mesmo para grandes corporações, que têm como objetivo a maximização da riqueza dos proprietários ou acionistas, motivo pelo qual é possível afirmar que grande parte da prática contábil ainda é executada com base na teoria da 
propriedade (KAM, 1986). Por esse enfoque, o proprietário tem direito residual sobre a entidade. O proprietário é uma pessoa natural ou um grupo de pessoas naturais, que é o dono do negócio e aquele que recebe o resíduo após o pagamento das despesas contratuais do negócio, possui todos os ativos e é o titular das dívidas (CHOW, 1942). O “proprietário é o centro da atenção da contabilidade. As receitas são consideradas como acréscimos de propriedade e as despesas, como decréscimos. Assim, o lucro líquido, diferença entre receitas e despesas, é adicionado diretamente ao proprietário.” (IUDÍCIBUS, 2009, p.168). Essa teoria está defasada para uma sociedade moderna, e foi desenvolvida em um tempo no qual as firmas eram pequenas. Com o advento do surgimento das grandes corporações mostrou-se inadequada como base para explicar a contabilidade corporativa (KAM, 1986).

b) Teoria da entidade: os interesses da entidade e do proprietário são segregados. Diz-se que a teoria da entidade precedeu o conceito de sociedades por ações. O lucro representa uma variação residual do patrimônio após deduzir todos os outro direitos, incluindo juros das dívidas a longo prazo e imposto de renda. Todos os pagamentos ou alocações a detentores de títulos devem ser considerados como distribuições do resultado da empresa. Receitas representam o produto da empresa, enquanto despesas correspondem aos bens e serviços consumidos no processo de geração de receitas. A empresa não se preocupa com valores correntes porque a ênfase reside na responsabilidade por custos perante os acionistas e outros titulares de direitos.(HENDRIKSEN; VAN BREDA, 1999).

Pela ótica dessa teoria, a sociedade é sua proprietária e é separada das pessoas naturais com as quais tem uma coexistência essencial (HUSBAND, 1938), tem personalidade própria (IUDÍCIBUS, 2009), e ao contrário do que acontece na teoria da propriedade, os juros, dividendos e impostos sobre a renda seriam despesas da sociedade (KAM, 1986). Na teoria da entidade, credores e acionistas estão em posição similar como provedores de fundos, assim justificando o tratamento de pagamento de juros e de dividendos como sendo da mesma categoria (KAM, 1986).

c) Teoria de direitos residuais: o acionista possui direitos em relação à empresa tal como outros titulares de direitos, mas o acionista não é considerado como proprietário. Embora os direitos de credores, acionistas preferenciais e acionistas ordinários devam ser registrados separadamente, são todos direitos. O objetivo desse enfoque é proporcionar melhor informação aos acionistas ordinários para a tomada de decisões de investimento. Considera-se 
que os acionistas ordinários detêm direitos residuais sobre o lucro da empresa e sobre os ativos líquidos, no caso de liquidação final. Os direitos dos acionistas ordinários, no balanço, devem ser apresentados separadamente dos direitos dos acionistas preferenciais, assim como de outros titulares de direitos. Em situação de continuidade da empresa, o capital inicial fornecido pelos acionistas ordinários, como os resultados retidos, são de propriedade da empresa (HENDRIKSEN; VAN BREDA, 1999).

Staubus (1959) considera que nenhuma das posições apresentadas pela teoria da propriedade, teoria da entidade e teoria dos fundos foi totalmente aceita pela profissão contábil nos Estados Unidos. Iudícibus (2009) afirma que de acordo com a teoria dos direitos residuais a contabilidade tem o objetivo de fornecer a melhor informação para o acionista ordinário.

d) Teoria empresarial: a empresa é vista como unidade social que age em nome de muitos grupos de interesse. A forma mais ampla da teoria empresarial pode ser vista como uma teoria social da contabilidade. É mais aplicável à moderna sociedade por ações, que leva em conta o efeito de suas atividades sobre toda a sociedade. A grande empresa não pode mais operar focada no interesse apenas dos acionistas, e o conceito de lucro envolve o valor de mercado dos bens e serviços por ela produzidos, menos o valor dos bens e serviços adquiridos e transferidos de outras empresas. Os lucros retidos, assim como na teoria da entidade, representam patrimônio não distribuído, da própria empresa (HENDRIKSEN; VAN BREDA, 1999).

Suojanen (1954) discorre sobre a teoria empresarial como resultado de uma nova ordem decorrente do surgimento de grandes corporações, cujas estruturas e comportamentos são distintos dos visualizados sob as teorias da propriedade e da entidade.

e) Teoria do fundo: a empresa é tratada como unidade operacional, orientada para atividades, como base da contabilidade. Todos os direitos representam restrições impostas por considerações legais, contratuais, gerenciais, financeiras ou de justiça. O conceito de fundo tem encontrado sua maior utilidade em instituições governamentais e sem fins lucrativos. $\mathrm{O}$ conceito de lucro pode ser mantido, mas não é o conceito principal na contabilidade financeira. É neutra em relação aos interesses de qualquer grupo específico (HENDRIKSEN; VAN BREDA, 1999). 
KAM (1986) introduz a ideia da teoria do fundo, como uma proposição de William Vatter, tendo como foco um fundo impessoal. O fundo é uma unidade de operações, um centro de interesse, com um propósito específico ou conjunto de atividades, que consiste em ativos e investimentos. A teoria do fundo é apresentada como extensão da teoria da entidade.

A diferença entre elas reside no fato de que, ao contrário do que acontece na teoria da entidade, onde a base da contabilidade é o proprietário ou a entidade, na teoria do fundo a base da contabilidade passa a ser um grupo de ativos e um conjunto de atividades ou funções para as quais esses ativos são utilizados. O fundo é dominado pelo grupo, e a teoria do fundo oferece uma alternativa para explicar a composição do patrimônio líquido (equity). Todo o lado direito do balanço representaria as restrições impostas ao lado esquerdo. Passivos totalizariam o total de restrições sobre os ativos. Na teoria do fundo, as relações pessoais que consubstanciam a teoria do proprietário e a personalização da firma como entidade legal e econômica artificial implícitas na teoria da entidade são abandonadas em favor desse núcleo de interesse, o grupo (IUDÍCIBUS, 2009).

f) Teoria do comando: essa teoria tem como enfoque o controle econômico e não a propriedade. Nela há o ponto de vista do comandante superior. O conceito de propriedade é difícil de definir e analisar, por isso as teorias da entidade e da propriedade não seriam apropriadas. Propriedade está ligada a uma relação legal, enquanto controle é uma função econômica. O comando sobre os recursos de uma companhia está nas mãos de uma hierarquia de comandantes. Todo gestor possui mais ou menos controle limitado sobre alguns recursos, e alguns poucos possuem o comando geral sobre todos os recursos. Na teoria do comando, demonstrações financeiras são relatórios de comandantes para comandantes. Procedimentos contábeis são tomados em benefício do comandante geral da firma, e não em benefício do proprietário da firma ou do fundo (GOLDBERG (1965) apud KAM, 1986).

Entretanto, "a teoria do comando falha da mesma forma que as teorias do proprietário e da entidade, em desenvolver um conceito geral que possa ser utilizado para descrever e avaliar toda a teoria contábil”, e essa teoria se preocupa mais com o que o comandante fez do que para quem os relatórios contábeis são dirigidos, contrariando, em parte, a essência informativa o os objetivos atuais da contabilidade (IUDÍCIBUS, 2009, p.171). 
As teorias relacionadas ao patrimônio líquido foram abordadas acima, e no quadro 1 estão resumidas as equações patrimoniais de cada uma delas.

\begin{tabular}{|l|l|}
\hline Teoria & Equação \\
\hline Teoria da Propriedade & $\begin{array}{l}\text { Ativos do proprietário - Passivos do proprietário = } \\
\text { PL/riqueza líquida do proprietário }\end{array}$ \\
\hline Teoria da Entidade & $\begin{array}{l}\text { Ativos = Direitos diversos em relação à empresa } \\
\text { (passivo + patrimônio de acionistas) }\end{array}$ \\
\hline $\begin{array}{l}\text { Teoria de Direitos } \\
\text { Residuais }\end{array}$ & Ativos - direitos específicos = direitos residuais \\
\hline Teoria do Fundo & Ativos = restrições sobre ativos \\
\hline
\end{tabular}

Fonte: Elaborado com base em Hendriksen e Van Breda, 1999, p.461-471

O que no Brasil recebeu o nome de "patrimônio líquido", representando a riqueza de maneira estática, pode ser visto sob a ótica de diversas teorias, como: proprietário, entidade, fundo, direitos residuais, empresarial e comando. As informações do patrimônio líquido dependem de todas as outras informações da sociedade, então, ao estudá-lo, estuda-se a situação de uma sociedade. O patrimônio líquido não tem uma forma direta de mensuração por depender de todos os outros componentes patrimoniais e acaba sendo explicado por esses componentes patrimoniais (ABE, 2007).

O FASB assumiu uma posição em favor da teoria dos direitos residuais ao definir o patrimônio dos proprietários como a participação residual nos ativos de uma entidade, remanescente após deduzir seus passivos. O órgão considerou ainda que o capital (que é igual a ativos líquidos), que seria igual a ativos líquidos, não tem existência independente de ativos e passivos por se tratar de um interesse residual (HENDRIKSEN; VAN BREDA, 1999).

O CPC assume postura similar, ao definir conceitos alinhados com os já definidos anteriormente pelo IASB. Nos termos do Pronunciamento Conceitual Básico (COMITÊ DE PRONUNCIAMENTOS CONTÁBEIS, 2008a, 2011b) “O montante pelo qual o patrimônio líquido é apresentado no balanço patrimonial depende da mensuração dos ativos e passivos.”.

O conceito de passivo está intimamente ligado ao conceito de obrigação, porém há casos em que formalmente não há obrigação constituída, mas há o surgimento de direitos diferentes daqueles que são dados aos acionistas com direito, como é o caso de direitos concedidos a acionistas detentores de ações preferenciais. Acredita-se, dessa forma, que essa abordagem pode não ser a que satisfaz a necessidade dos acionistas ordinários e que patrimônio líquido 
poderia ser definido de uma maneira mais restrita, alargando consequentemente o conceito de passivo. No entanto, não é somente o interesse de acionistas ordinários que está em questão, uma vez que o objetivo das demonstrações contábeis é o de fornecer informação a diversas modalidades de usuários e não, apenas a acionistas (IFRS FOUNDATION, 2012b).

O patrimônio líquido é um valor residual composto por dois grandes conjuntos, que são as transações com sócios, divididas em capital e reservas de capital, e os resultados abrangentes, divididos em reserva de lucros ou prejuízos acumulados e outros resultados abrangentes. Não possui critério próprio de avaliação, dependendo dos critérios de avaliação dos ativos e dos passivos (IUDÍCIBUS et al., 2010).

Embora tenha sido definido como um valor residual pode ter subclassificações na demonstração de posição financeira, como recursos aportados pelos sócios, reservas resultantes de apropriações de lucros e reservas para a manutenção do capital, que podem ser demonstrados separadamente (ERNST \& YOUNG; FIPECAFI, 2010).

Basicamente, as fontes principais do patrimônio líquido são decorrentes de:

\footnotetext{
1. valores líquidos pagos por acionistas;

2. excesso de lucro líquido sobre dividendos pagos (lucros retidos ou acumulados na empresa);

3. valores resultantes de correções (ajustes patrimoniais) de ativos;

4. vários tipos de reservas de capital. (IUDÍCIBUS, 2009, p.172)
}

Além dos itens previstos expressamente pela Lei no 6.404/1976 e suas alterações, o grupo patrimônio líquido pode apresentar outras contas para melhor evidenciar a situação patrimonial na companhia ou, então, atender a normatizações específicas, são exemplos as contas: opções outorgadas reconhecidas, gastos na emissão de ações, ajustes acumulados de conversão e, também, contas extintas mas com saldos remanescentes, como é o caso da reserva de reavaliação e a conta de prêmio na emissão de debêntures e doações e subvenções para investimentos na forma de reserva de capital (IUDÍCIBUS et al., 2010).

Resta clara, logo, a estreita conexão entre a estrutura conceitual contábil vigente no país, e a teoria dos direitos residuais, à medida que a normatização estabelece que os acionistas possuem direitos em relação à empresa, assim como demais titulares de direitos, mas o acionista não é considerado proprietário. 
O patrimônio líquido da empresa, por sua natureza, representa contabilmente o valor residual dos sócios após liquidados ativos e passivos, e por ser assim que se torna relevante aos usuários da contabilidade. O patrimônio líquido comumente é utilizado como parâmetro para se calcular o retorno que o investimento proporciona aos investidores, comparando-se o resultado obtido em um determinado período com o capital investido, ou em outras palavras, com o capital que deixou de ser resgatado no início do período e optou-se por deixá-lo à disposição da empresa para que pudesse gerar resultados.

Ao medir o resultado proporcionado pelas atividades da empresa, normalmente por cálculos, dividindo-se o lucro do período pelo patrimônio líquido à disposição da entidade, é possível permitir ao investidor uma base para que possa comparar o resultado obtido pelo seu investimento na empresa com outros que deixou de realizar ao optar por deixar esses recursos à disposição dessa mesma empresa.

Cabe ressaltar que há formas distintas de se apurar o retorno proporcionado pela empresa ao investidor, principalmente quando se trata de qual valor do patrimônio líquido deve ser utilizado nessa análise. Nesse caso, deve ser recordada a lição de Martins et al (2012) ao alertar que não se deve utilizar o valor do patrimônio líquido do final do exercício para se calcular o retorno proporcionado aos acionistas pois esse valor contém o próprio lucro gerado no exercício em questão, e também devem ser consideradas as variações no patrimônio ocorridas durante o exercício social, como aumento de capital, distribuições de dividendos e outros, para uma correta análise.

\subsection{Alterações no patrimônio líquido introduzidas pelas Leis $\mathrm{n}^{\circ \mathrm{s}} \cdot \mathbf{1 1 . 6 3 8 / 2 0 0 7} \mathrm{e}$ 11.941/2008}

A desvinculação entre normas contábeis e fiscais tem evoluído no Brasil. A Lei nำ6.404/1976 prevê:

Art. 177. A escrituração da companhia será mantida em registros permanentes, com obediência aos preceitos da legislação comercial e desta Lei e aos princípios de contabilidade geralmente aceitos, devendo observar métodos ou critérios contábeis uniformes no tempo e registrar as mutações patrimoniais segundo o regime de competência.

$\S$ 1 As demonstrações financeiras do exercício em que houver modificação de métodos ou critérios contábeis, de efeitos relevantes, deverão indicá-la em nota e ressaltar esses efeitos. 
§ 2ㅇ A companhia observará exclusivamente em livros ou registros auxiliares, sem qualquer modificação da escrituração mercantil e das demonstrações reguladas nesta Lei, as disposições da lei tributária, ou de legislação especial sobre a atividade que constitui seu objeto, que prescrevam, conduzam ou incentivem a utilização de métodos ou critérios contábeis diferentes ou determinem registros, lançamentos ou ajustes ou a elaboração de outras demonstrações financeiras. (BRASIL, 1976).

Dessa maneira, já havia previsão legal para desvinculação entre normas contábeis e fiscais, quando da fixação de livros ou registros auxiliares para registro de disposições em matéria tributária, não surtindo, assim, efeito na escrituração contábil, denominada na citada lei como escrituração mercantil. No entanto, para que essa desvinculação fosse claramente aplicada no processo de convergência de normas pelo qual o Brasil tem passado, a Lei nํㅜ 11.941/2009 instituiu o Regime Tributário de Transição - RTT, inicialmente previsto para vigorar nos exercícios de 2008 e 2009, e se estende até os dias atuais (2013). O RTT vigerá “até a entrada em vigor de lei que discipline os efeitos tributários dos novos métodos e critérios contábeis, buscando a neutralidade tributária." (BRASIL, 2009).

No Brasil, historicamente, a contabilidade sempre esteve vinculada à legislação tributária. Houve uma tentativa de segregação das duas com a edição da Lei nํ 6.404/1976, com a utilização de livros auxiliares. Entretanto, as normas contábeis e fiscais estavam intrinsecamente ligadas. A edição da Lei nำ 11.638/2007 prezou pela independência da contabilidade, separando-a das normas tributárias, e tratou da convergência do Brasil aos padrões internacionais de contabilidade. A nova contabilidade tem razoável subjetividade e, sendo o tributo apurado por meio de normas tributárias, não pode ser obtido por normas subjetivas. Dessa maneira, o contribuinte deverá apurar duas contabilidades, uma societária e uma fiscal a partir de ajustes sobre a primeira (CALIJURI, 2011).

Com a edição das Leis no ${ }^{\circ}$ 11.638/2007 e 11.941/2009 manteve-se a necessidade de separação das contabilidades societária e fiscal com a criação do Regime Tributário de Transição, na busca por uma Contabilidade Societária (Direito Contábil Societário) livre da influência da Contabilidade Fiscal (Direito Contábil Tributário). Apesar da separação entre essas áreas é possível verificar pontos de intersecção entre a Ciência Contábil, o Direito Contábil Societário e o Direito Contábil Fiscal (MOSQUERA; FREITAS, 2011). 


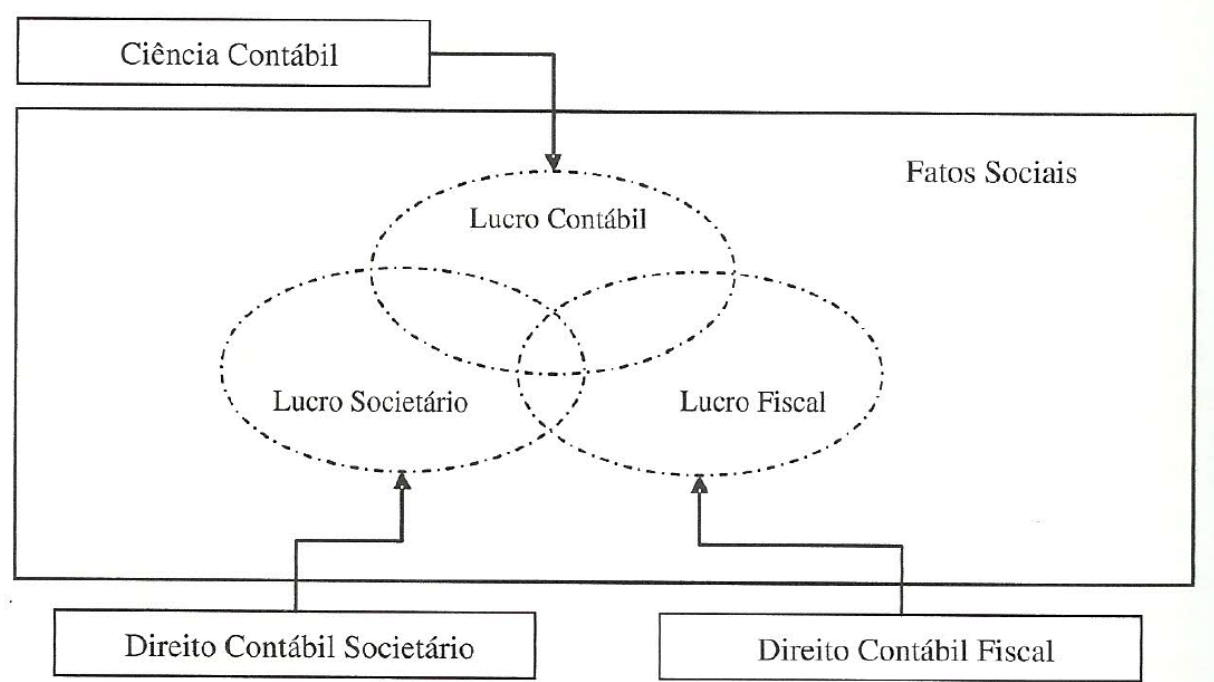

Ilustração 1 - Diagrama de intersecção entre ciência contábil, contabilidade societária e contabilidade fiscal

Fonte: Mosquera e Freitas,2011

Com relação à vinculação entre normas contábeis e fiscais, Ignacio (2010) revela que apesar da Lei n-11.638/2007 ter proposto a desvinculação dessas normas, é possível verificar que a prometida desvinculação não foi completa até a data de sua pesquisa, e que o grau de conexão entre as normas contábeis e fiscais, no Brasil, foi reduzido, mas não extinto.

A orientação fiscal dos diversos sistemas nacionais inclusive foi apontada como uma das principais barreiras ao trabalho do IASB de harmonização de normas contábeis (LARSON; STREET, 2004).

A harmonização contábil pode ocorrer em dois âmbitos: nas práticas (harmonização de fato) e nas normas (harmonização de direito), e esses dois âmbitos não são necessariamente coincidentes. Não há um consenso sobre o grau de importância de cada uma dessas partes componentes da harmonização contábil. A harmonização de direito pode eventualmente não conduzir à harmonização de fato em função da fraqueza de aplicação da norma ou, então, fatores culturais. Nesse sentido, seria desejável que a harmonização de normas contábeis ocorresse por meio de adesão voluntária das empresas (WEFFORT, 2005).

Experiências anteriores têm mostrado que nem sempre a convergência de direito conduz à convergência de fato, uma vez que diversas questões são cruciais para a adoção efetiva das IFRSs localmente, como os sistemas de financiamento das empresas, sistema jurídico, grau de proteção do investidor minoritários e valores culturais (LAGE et al., 2010). 
Experiências de outros países mostram que o processo de convergência de demonstrações financeiras para as IFRSs pode ser complexo, de longa duração e resultar em impactos expressivos no resultado e no patrimônio líquido das empresas. O efeito sobre o preço de suas ações nos mercados de capitais pode ser significativo (SILVA et al., 2010).

Lima (2010) aponta que recentes pesquisas em contabilidade têm evidenciado que os resultados da adoção das normas internacionais de maior qualidade, como USGAAP ou IFRS, não necessariamente implicam em uma contabilidade com maior qualidade. Concluiu que as informações contábeis estudadas possuíam conteúdo informacional, que as demonstrações contábeis de empresas com incentivo para serem mais informativas não apresentaram diferença com relação ao seu conteúdo informacional antes e após implementação das novas regras contábeis, que a relevância da informação contábil mensurada pelos modelos de preço e retorno aumentou após a adoção parcial das normas internacionais, e que os ajustes de reconciliação do lucro líquido e do patrimônio líquido no período de transição entre o padrão brasileiro e as normas IFRSs são relevantes para o mercado de capitais. Indica que os mesmos eventos econômicos quando mensurados por diferentes normas contábeis alteram expectativas dos investidores acerca do resultado futuro da empresa, modificando assim preços das ações.

A adoção das normas internacionais de contabilidade resultou em diferenças significativas no ano de sua adoção, entre as demonstrações contábeis elaboradas de acordo com o padrão local de contabilidade e as normas internacionais. Essa afirmação pode ser constatada pelo estudo de Cambria (2008), no qual foram analisados grupos do balanço patrimonial de empresas químicas e de mineração do Reino Unido, da Alemanha e da França.

No Brasil, apurou-se que a adoção das IFRSs foi refletida na análise financeira das empresas que negociam ações na BM\&F Bovespa. Foram observadas variações positivas nos indicadores de endividamento, de liquidez geral e corrente, enquanto foram observadas variações negativas sobre os indicadores de dependência financeira, de imobilização de recursos permanentes, de retorno sobre o patrimônio líquido e de retorno sobre o ativo. As maiores variações referiram-se aos indicadores de rentabilidade, principalmente ao retorno sobre o patrimônio líquido, como reflexo das divergências de reconhecimento das receitas e apropriação das despesas existentes entre BR GAAP e as IFRSs (MARTINS; PAULO, 2010). 
A transição de normas contábeis no Brasil deu-se em duas etapas: ciclos 2007/2008 e 2009/2010. No primeiro ciclo, os ajustes decorrentes da nova normatização contábil afetaram negativamente o resultado e no segundo ciclo, os ajustes afetaram positivamente o patrimônio líquido das empresas estudadas, grupo esse formado pelas empresas cujas ações foram mais negociadas na BM\&FBovespa, componentes de um grupo com elevado volume de negociação, o IBrX-100 (Acuña et al., 2012).

Órgãos reguladores, empresas de capital aberto e demais partes interessadas defendem que o processo de harmonização internacional das práticas contábeis pode potencializar a utilidade da informação contábil. Em estudo baseado em 50 companhias abertas brasileiras verificou-se o aumento da relevância das informações contábeis após a adoção das normas internacionais de contabilidade (BARROS et al., 2013).

O lucro líquido por ação, assim como o valor do patrimônio líquido por ação são informações relevantes aos usuários da informação contábil, porém houve um ganho informacional a partir do início das normas internacionais de contabilidade, e pode estar associado à introdução de novos critérios de mensuração e reconhecimento contábil, pois tendem a deixar a informação contábil mais próxima da realidade econômica da empresa, destacando-se, também, a melhoria do disclosure, tanto em termos quantitativos como qualitativos (MACEDO et al., 2012).

O patrimônio líquido não pode ser avaliado separadamente dos ativos e dos passivos, pois não é independente. A forma como são avaliados itens do ativo e do passivo reflete diretamente no valor apresentado no balanço patrimonial do patrimônio líquido. Por decorrência das normas contábeis vigentes no país a partir de 2008, em função do processo de convergência internacional de normas contábeis, o valor de ativos e passivos, e, consequentemente, patrimônio líquido, sofreram alterações.

Contudo, a questão pode ir um pouco além do valor total do patrimônio líquido, que comporta subgrupos e contas distintas, representando diferentes restrições relacionadas ao direito dos acionistas. O CPC esclarece quanto a classificações dos componentes do patrimônio líquido e sua importância:

Embora o patrimônio líquido seja definido no item 4.4 como algo residual, ele pode ter subclassificações no balanço patrimonial. Por exemplo, na sociedade por ações, recursos aportados 
pelos sócios, reservas resultantes de retenções de lucros e reservas representando ajustes para manutenção do capital podem ser demonstrados separadamente. Tais classificações podem ser relevantes para a tomada de decisão dos usuários das demonstrações contábeis quando indicarem restrições legais ou de outra natureza sobre a capacidade que a entidade tem de distribuir ou aplicar de outra forma os seus recursos patrimoniais. Podem também refletir o fato de que determinadas partes com direitos de propriedade sobre a entidade têm direitos diferentes com relação ao recebimento de dividendos ou ao reembolso de capital. (COMITE DE PRONUNCIAMENTOS CONTÁBEIS, 2008a).

Alguns componentes do patrimônio líquido passaram a existir em 2008. Outros componentes que anteriormente eram classificados em outros locais nas demonstrações contábeis passaram a figurar no patrimônio líquido.

As principais alterações no patrimônio líquido a partir de 2008 são relacionadas e tratadas com maior detalhamento na sequencia.

\subsubsection{Ajustes de avaliação patrimonial}

Trata-se de uma subdivisão do patrimônio líquido expressa por lei federal. Originalmente, o artigo 178 da Lei n- 6404/1976 não previa essa subdivisão, que passou a ser prevista pela Lei nํ⒒638/2007. Sua definição sofreu alteração pela Lei no $11.941 / 2009$, que é a conversão em lei da Medida Provisória 449 de 2008.

Pela Lei n- $11.638 / 2007$, ajustes de avaliação patrimonial eram itens ainda não computados no resultado do exercício em obediência ao regime de competência, decorrentes de "contrapartidas de aumentos ou diminuições de valor atribuído a elementos do ativo ( $\$$ o do art. 177, inciso I do caput do art. 183 e $§ 3 \circ$ do art. 226 desta lei) e do passivo, em decorrência da sua avaliação a preço de mercado".

Entretanto, a Lei no $11.941 / 2009$ alterou a referida definição, substituindo a expressão “avaliação a preço de mercado" por "avaliação a valor justo", terminologicamente mais correta, uma vez que preço de mercado e avaliação a valor justo não são sinônimos, muito embora eventualmente possam resultar em valores idênticos.

Valor justo pode ser definido de acordo com o Pronunciamento Técnico CPC 46 como o preço que seria recebido pela venda de um ativo ou que seria pago pela transferência de um passivo em uma transação não forçada entre participantes do mercado na data de mensuração. Esse preço pode ser diretamente observável ou estimado utilizando-se outra técnica de avaliação. $\mathrm{O}$ valor de mercado consiste em uma das técnicas para se avaliar o valor justo. São 
elas: (i) abordagem de mercado que utiliza preços e outras informações relevantes geradas por transações de mercado envolvendo ativos, passivos ou grupo de ativos e passivos idênticos ou comparáveis, (ii) abordagem de custo que reflete o valor necessário na ocasião para substituir a capacidade do serviço de ativo e (iii) abordagem de receita que converte valores futuros em um único valor atual, refletindo as expectativas de mercado atuais em relação a esses valores futuros (COMITÊ DE PRONUNCIAMENTOS CONTÁBEIS, 2012).

A conta de ajustes de avaliação patrimonial contempla as contrapartidas de ajustes a preço de mercado de ativos e passivos decorrentes de reestruturações societárias, avaliações de instrumentos financeiros, normas emitidas pela CVM em consonância com os padrões internacionais de contabilidade, e segundo comunicado ao mercado emitido pela CVM em 14/01/2008, também são classificados na conta de ajustes de avaliação patrimonial os ajustes de conversão em função da variação cambial de investimentos societários no exterior (BRAGA; ALMEIDA, 2008).

Os valores que compõem a conta de ajustes de avaliação patrimonial não transitaram pelo resultado, culminando na impossibilidade de classificá-la como reserva, e deverão ser transferidos para o resultado do exercício à medida que os ativos e passivos forem sendo realizados (IUDÍCIBUS et al., 2010).

Relevante ressaltar que valores registrados no patrimônio líquido como contrapartida de avaliação a valor justo de componentes patrimoniais não são exatamente uma novidade introduzida na contabilidade nacional pelos pronunciamentos do CPC. Isso porque instituições financeiras já faziam esse tipo de registro como demonstra a Circular no 3068 do Banco Central do Brasil:

Art. $2^{\circ}$ Os títulos e valores mobiliários classificados nas categorias referidas no artigo anterior, incisos I e II, devem ser ajustados pelo valor de mercado, no mínimo por ocasião dos balancetes e balanços, computando-se a valorização ou a desvalorização em contrapartida:

I - à adequada conta de receita ou despesa, no resultado do período, quando relativa a títulos e valores mobiliários classificados na categoria títulos para negociação;

II - à conta destacada do patrimônio líquido, quando relativa a títulos e valores mobiliários classificados na categoria títulos disponíveis para venda, pelo valor líquido dos efeitos tributários. (BANCO CENTRAL DO BRASIL, 2001). 
A Superintendência de Seguros Privados - SUSEP também já possuía previsão semelhante antes da introdução das normas do CPC como pode ser verificado pela Circular no 192:

Dos Títulos e Valores Mobiliários Disponíveis Para Venda

(...)

Art. 7o O valor contábil dos títulos e valores mobiliários classificados na categoria títulos disponíveis para venda deve ser ajustado ao valor de mercado, pelo menos por ocasião dos balancetes e balanços, computando-se a valorização ou a desvalorização em contrapartida a conta destacada do patrimônio líquido, pelo valor líquido dos efeitos tributários.

Parágrafo único. Os ganhos e perdas não realizados registrados em conta destacada do patrimônio líquido, na forma do "caput", devem ser apropriados ao resultado do período em que ocorrer a venda dos títulos e valores mobiliários classificados na categoria títulos disponíveis para venda. (SUSEP, 2002).

A referida normatização do Banco Central do Brasil, assim como da Superintendência de Seguros Privados, já previam que títulos para negociação e títulos disponíveis para venda deveriam ser ajustados pelo valor de mercado. A contrapartida desses ajustes seria realizada em conta específica do patrimônio líquido da empresa no caso dos títulos disponíveis para venda. O que houve com a introdução da normatização do CPC foi uma massificação desse procedimento de avaliação de componentes patrimoniais pelo valor justo, não mais ficando restrito a instituições financeiras e seguradoras.

A conta de ajustes de avaliação representa uma parte do patrimônio líquido que está sujeita à realização futura para se tornar parte permanente dele. Valores nela contidos podem vir a nunca ser realizados e, ainda, que o sejam, não é possível determinar com exatidão o momento dessa realização, de todo o seu saldo. Nesse ponto, ela se difere do restante do patrimônio líquido que é representado por valores que não dependem de realização futura para permanecerem nesse grupo.

\subsubsection{Prêmio recebido na emissão de debêntures e doações e subvenções para investimentos}

Os valores recebidos a título de prêmio na emissão de debêntures, assim como valores recebidos a título de doações e subvenções para investimentos figuravam no patrimônio líquido, dentro das reservas de capital, por força do texto original da Lei nำ 6.404/1976. Tal previsão foi excluída pela Lei nํ⒒637/2008. 
Os tipos mais comuns de doações são em dinheiro ou em bens móveis, imóveis ou direitos, e de subvenções são as representadas por recursos concedidos pelo governo a empresas públicas ou, então, de economia mista, devendo ser aplicados em imobilizações ou em reduções de impostos (IUDÍCIBUS et al., 2010).

Os valores registrados sob esse título passaram a ser registrados em conta de resultado. $\mathrm{O}$ artigo 195-A da Lei nำ 6.404/1976 com alterações pela Lei nำ11.638/2007, passou a prever a possibilidade da assembleia geral "por proposta dos órgãos da administração, destinar para a reserva de incentivos fiscais a parcela do lucro líquido decorrente de doações ou subvenções governamentais para investimentos, que poderá ser excluída da base de cálculo do dividendo obrigatório.".

Por analogia, a parcela do lucro decorrente da amortização do prêmio recebido na emissão de debêntures pode também ser destinada para conta específica dentro do patrimônio líquido, desde que não distribuída como dividendo (COMITÊ DE PRONUNCIAMENTOS CONTÁBEIS, 2008b).

Assim como a legislação contábil anterior, os valores destinados a reservas de incentivos fiscais não compõem a base de cálculo do dividendo obrigatório, conforme artigo 195-A da Lei nํ 6.404/1976, incluído pela Lei nำ 11.638/2007. Antes das alterações introduzidas, os valores eram registrados diretamente no patrimônio líquido, não compondo, dessa forma, o resultado do período, e consequentemente a base de cálculo do dividendo obrigatório.

\subsubsection{Reserva de reavaliação}

A alteração promovida pela Lei no $11.638 / 2007$ passa a não mais permitir a reavaliação de itens do ativo.

A reavaliação, que consiste na avaliação espontânea de ativos por seu valor de mercado quando superior ao custo, não pode ser confundida com a correção monetária, que é somente a atualização monetária do custo de aquisição, existindo ainda vínculo com o preço pago pelo ativo. Na reavaliação, o custo é abandonado e substituído por valor novo. A eliminação da possibilidade de se reavaliar ativos está em desacordo com as normas internacionais, que permitem esse tipo de procedimento, e está associada ao mau uso desse mecanismo. A reavaliação originada em bons propósitos transformou-se, no Brasil, em procedimento que 
trouxe mais dificuldades aos leitores externos do que utilidade, apesar da emissão de diversas normas, principalmente por parte da CVM (IUDÍCIBUS, 2010).

Os valores registrados pelas empresas sob esse título puderam, pela adoção inicial, em 2008, ser mantidos até efetiva realização ou então estornados até o término do exercício social de 2008 (COMITÊ DE PRONUNCIAMENTOS CONTÁBEIS, 2008b). Assim, apesar de não mais haver previsão sobre a possibilidade de realização de reavaliação de itens do ativo imobilizado, ainda é possível a existência de valores nas contas de reserva de reavaliação, desde que se refiram a reavaliações realizadas até o exercício social de 2007.

\subsubsection{Lucros acumulados}

Por meio das alterações introduzidas pela Lei nํ 11.638/2007, não há mais previsão legal sobre a manutenção da conta lucros acumulados como componente do patrimônio líquido das empresas. O que não significa que essa conta deixa de existir. O que passou a existir foi a obrigatoriedade de dar destinação a todo o valor constante em tal conta, ou seja, seu saldo final deve ser igual a zero. Como prova dessa afirmação, seria suficiente verificar as Demonstrações das Mutações do Patrimônio Líquido - DMPLs publicadas pelas empresas, constatando-se, desse modo, que a referida conta ainda existe e não poderia ser diferente, uma vez que representa o elo de ligação entre as contas de resultado e as contas patrimoniais.

Cabe ressaltar que a restrição em tela não se aplica às empresas que não sejam classificadas como sociedades por ações, como expresso pela Orientação OCPC 02:

115. A obrigação de essa conta não conter saldo positivo aplica-se unicamente às sociedades por ações, e não às demais, e para os balanços do exercício social terminado a partir de 31 de dezembro de 2008. Assim, saldos nessa conta precisam ser totalmente destinados por proposta da administração da companhia no pressuposto de sua aprovação pela assembleia geral ordinária.

116. Essa conta continua nos planos de contas, e seu uso continua a ser feito para receber o resultado do exercício, as reversões de determinadas reservas, os ajustes de exercícios anteriores, para distribuir os resultados nas suas várias formas e destinar valores para reservas de lucros. (COMITÊ DE PRONUNCIAMENTOS CONTÁBEIS, 2009a).

"No caso de sociedades que não sejam por ações, podem existir lucros retidos ainda não destinados a reservas ou à distribuição aos sócios. Nesse caso podem ficar sob a rubrica de Lucros Acumulados.” (IUDÍCIBUS et al., 2010, p.343). 
A previsão normativa deixa clara a impossibilidade de manutenção dos saldos da conta lucros acumulados como componente do patrimônio líquido das empresas. No entanto, seria pouco provável que essa restrição alterasse o valor total do patrimônio líquido, já que, na prática, significa uma alocação a outras contas componentes do patrimônio líquido.

\subsubsection{Gastos com emissão de ações}

O conceito de gastos com emissão de ações deriva do conceito de custos de transação, nos termos apresentados pelo CPC no Pronunciamento Técnico CPC 08 (R1), que os define como custos de transação incorridos e diretamente atribuíveis às atividades necessárias exclusivamente às transações de distribuição primária de ações ou bônus de subscrição, de aquisição e alienação de ações próprias, captação de recursos por meio de contratação de empréstimos ou financiamentos ou pela emissão de títulos de dívida, bem como prêmios na emissão de debêntures ou outros instrumentos de dívida ou de patrimônio líquido (COMITÊ DE PRONUNCIAMENTOS CONTÁBEIS, 2010a).

São exemplos de custos de transação:

\footnotetext{
i) gastos com elaboração de prospectos e relatórios;

ii) remuneração de serviços profissionais de terceiros (advogados, contadores, auditores, consultores, profissionais de bancos de investimento, corretores, etc.);

iii) gastos com publicidade (inclusive os incorridos nos processos de road-shows);

iv) taxas e comissões;

v) custos de transferência;

vi) custos de registro etc. (COMITÊ DE PRONUNCIAMENTOS CONTÁBEIS, 2010a).
}

Custos de transação não incluem ágios ou deságios na emissão dos títulos e valores mobiliários, despesas financeiras, custos internos administrativos ou custos de carregamento (COMITÊ DE PRONUNCIAMENTOS CONTÁBEIS, 2010a).

Os gastos com emissão de ações "devem ser contabilizados, de forma destacada, em conta redutora de patrimônio líquido, deduzidos os eventuais efeitos fiscais, e os prêmios recebidos devem ser reconhecidos em conta de reserva de capital." (COMITÊ DE PRONUNCIAMENTOS CONTÁBEIS, 2010a).

O que a empresa gasta para conseguir mais capital não é considerado um valor relacionado à sua atividade operacional, mas, sim, relacionado a uma transação de capital entre empresa e 
sócios, que redunda num ingresso líquido de recursos, estes, sim, reconhecidos como aumento líquido de capital (IUDÍCIBUS et al., 2010).

Anteriormente à normatização introduzida pelo CPC, os gastos com emissão de ações eram levados à contabilização em conta de resultado, normalmente amortizado em mais de um período.

\subsubsection{Dividendo adicional proposto}

A proposta de distribuição de dividendos corresponde à parte dos lucros que a empresa decidiu destinar aos acionistas e ainda não o fez. O total dos dividendos que podem vir a ser distribuídos aos sócios ou acionistas se divide em obrigatório e adicional proposto.

\section{Pelo Pronunciamento Conceitual Básico (COMITÊ DE PRONUNCIAMENTOS} CONTÁBEIS, 2008a), "passivo é uma obrigação presente da entidade, derivada de eventos passados, cuja liquidação se espera que resulte na saída de recursos da entidade capazes de gerar benefícios econômicos.”.

Os acionistas têm direito a receber o que se chama de dividendo obrigatório, regulamentado pela Lei $\mathrm{n}-6.404 / 1976$ :

Art. 202. Os acionistas têm direito de receber como dividendo obrigatório, em cada exercício, a parcela dos lucros estabelecida no estatuto ou, se este for omisso, a importância determinada de acordo com as seguintes normas: (Redação dada pela Lei nº 10.303, de 2001)

I - metade do lucro líquido do exercício diminuído ou acrescido dos seguintes valores: (Redação dada pela Lei no 10.303 , de 2001)

a) importância destinada à constituição da reserva legal (art. 193); e (Incluída pela Lei nº 10.303, de 2001)

b) importância destinada à formação da reserva para contingências (art. 195) e reversão da mesma reserva formada em exercícios anteriores; (Incluída pela Lei no 10.303, de 2001) (BRASIL, 1976).

Dessa maneira, uma parte do valor que a companhia se compromete a pagar a título de dividendos ou juros sobre o capital próprio (equiparado legalmente ao dividendo mínimo obrigatório por força da Lei no 9.249/1995), sem dúvida pode ser classificada como obrigação presente da entidade, ou seja, passivo. 
No entanto, a parcela dos dividendos que excede o obrigatório e que ainda não foi aprovada pela assembleia da companhia, não tem essa característica de obrigação presente da entidade, não podendo, assim, ser classificada como passivo.

Um passivo deve ser reconhecido quando existe uma obrigação legal que faça com que a entidade não possua alternativa realista a não ser pagar tal obrigação. A assembleia dos sócios é soberana quanto à distribuição de dividendos, e com relação ao mínimo obrigatório, tem limites muito estreitos para deliberar sobre o seu não pagamento, sendo essas ocasiões muito raras, em especial no caso de companhias abertas. Considerando as características de nossa legislação, o dividendo mínimo obrigatório ainda não pago deve figurar no balanço patrimonial como passivo. O que não acontece com a parcela adicional do dividendo em proposta da administração antes da data do balanço como disposto na Interpretação Técnica ICPC 08 (COMITÊ DE PRONUNCIAMENTOS CONTÁBEIS, 2009c).

[...] a parcela do dividendo mínimo obrigatório, que se caracterize efetivamente como uma obrigação legal, deve figurar no passivo da entidade. Mas a parcela da proposta dos órgãos da administração à assembleia de sócios que exceder a esse mínimo obrigatório deve ser mantida no patrimônio líquido, em conta específica, do tipo "dividendo adicional proposto", até a deliberação definitiva que vier a ser tomada pelos sócios. Afinal, esse dividendo adicional ao mínimo obrigatório não se caracteriza como obrigação presente na data do balanço, já que a assembleia dos sócios ou outro órgão competente poderá, não havendo qualquer restrição estatutária ou contratual, deliberar ou não pelo seu pagamento ou por pagamento por valor diferente do proposto (COMITE DE PRONUNCIAMENTOS CONTÁBEIS, 2009c).

A Lei das S.A. exige a contabilização da proposta integral do resultado, e o valor excedente ao mínimo obrigatório deve ser registrado debitando-se lucros ou prejuízos acumulados e creditando-se conta especial do patrimônio líquido (IUDÍCIBUS et al., 2010).

A divulgação da informação da conta dividendo adicional proposto pelas empresas de capital aberto é value relevant para o mercado de capitais considerando-se as demonstrações contábeis de 2010. A variável relacionada a essa conta chegou a exercer maior influência sobre os preços das ações do quê as variáveis lucro líquido e patrimônio líquido excluindo-se o valor da conta de dividendos adicionais propostos, concluiu estudo realizado por Silva et al (2013). 
Formalmente não subsiste dúvida quanto à forma de contabilização, substancialmente diferente da normatização anterior à existência do CPC, época em que o total dos dividendos figurava no passivo das empresas, independente da aprovação da assembleia de sócios.

Contudo, historicamente verifica-se ser comum a efetiva distribuição dos dividendos adicionais propostos aos sócios, significando que esse valor destacado no patrimônio líquido ficará nesse grupo por um prazo curto. Dessa forma, caberia uma atenção especial ao tratar esse item, por ocasião da utilização das informações contábeis.

\subsubsection{Participação de acionistas não controladores}

A participação de acionistas não controladores, algumas vezes também apresentada pela nomenclatura de acionistas minoritários (embora não necessariamente o sejam), deve figurar dentro do patrimônio líquido das entidades. É válido ressaltar que acionista não controlador não significa acionista minoritário. Uma nomenclatura refere-se a exercer controle, outra se refere a possuir mais ações. Sendo assim, um acionista tido como minoritário pode vir a controlar uma companhia, dependendo se sua estrutura acionária e composição de seu patrimônio líquido em ações com e sem direito a voto.

O CPC por meio do Pronunciamento Técnico CPC 26 (R1) estabelece:

\footnotetext{
O balanço patrimonial deve apresentar, respeitada a legislação, no mínimo, as seguintes contas:

$(\ldots)$

(q) participação de não controladores apresentada de forma destacada dentro do patrimônio líquido; e

(...) (COMITÊ DE PRONUNCIAMENTOS CONTÁBEIS, 2011a).
}

Essa participação destacada dentro do patrimônio líquido não era apresentada dessa maneira antes da normatização proveniente do CPC. A participação era apresentada como parte autônoma do lado direito do balanço patrimonial, o que não mais poderia acontecer, em virtude da estrutura atual emanada da atual normatização contábil, como pode ser atestado pela Deliberação 488/2005 da Comissão de Valores Mobiliários - CVM:

64. No mínimo, o balanço patrimonial deve incluir rubricas que apresentem os montantes das principais contas ou grupo de contas, se aplicável, em ordem decrescente de liquidez ou exigibilidade, que normalmente inclui o seguinte: 
No ativo (segregando o ativo circulante dos demais ativos):

a. disponibilidades e aplicações financeiras resgatáveis no prazo de 90 dias da data do balanço;

b. títulos e valores mobiliários;

c. contas a receber de clientes;

d. estoques;

e. pagamentos antecipados;

f. créditos diversos;

g. impostos diferidos;

h. investimentos, segregando as participações em entidades controladas e coligadas (e a elas equiparadas) e outros investimentos;

i. ativo imobilizado;

j. ativo intangível; e

k. ativo diferido.

No Passivo (segregando o passivo circulante dos demais passivos):

a. financiamentos;

b. contas a pagar a fornecedores;

c. impostos sobre a renda a pagar;

d. outros tributos a recolher;

e. provisões (com indicação de sua natureza).

Participação de acionistas não controladores

No Resultado de Exercícios Futuros

a. as receitas líquidas recebidas referentes às receitas líquidas, mas ainda não realizadas contabilmente em função do atendimento ao regime de competência dos exercícios, para as quais não haja qualquer tipo de obrigação de devolução, seja pela entrega de ativos ou prestação de serviço;

b. o deságio não eliminado na consolidação, quando aplicável.

No patrimônio líquido:

a. capital;

b. reservas, com indicação de sua natureza; e

c. lucros ou prejuízos acumulados. (COMISSÃO DE VALORES MOBILIÁRIOS, 2005)

Por essa exposição, pode ser verificado que o patrimônio líquido passa a comportar mais um componente que não cabia a ele comportar anteriormente à implantação da nova normatização contábil no país.

\subsection{Limitações relacionadas à ausência de correção monetária das demonstrações contábeis}

Por força da Lei n 9.249/1995, nos dias atuais não é permitida qualquer atualização monetária com vistas ao reconhecimento da inflação nas demonstrações contábeis.

[...] Art. $4^{\circ}$ Fica revogada a correção monetária das demonstrações financeiras de que tratam a Lei $\mathrm{n}^{\mathrm{o}} 7.799$, de 10 de julho de 1989 , e o art. $1^{\text {o }}$ da Lei $\mathrm{n}^{\mathrm{o}} 8.200$, de 28 de junho de 1991. 
Parágrafo único. Fica vedada a utilização de qualquer sistema de correção monetária de demonstrações financeiras, inclusive para fins societários. [...] (BRASIL, 1995).

No Brasil já existiu aproximadamente $2.000 \%$ de inflação em um único ano. Já houve inflação de $80 \%$ em um mês. Ainda assim, o país cresceu economicamente e a Contabilidade conseguiu encontrar mecanismos criativos para conviver com esse cenário. A Instrução da CVM nำ 64 de 19 de maio de 1987 criou regras para a elaboração de demonstrações contábeis em moeda aquisitiva constante, nas quais também ficava clara a necessidade de se ajustar ativos e passivos prefixados aos seus respectivos valores presentes (SANTOS, 2012).

Em estudo sobre a percepção da inflação por pessoas de diversas formações, identificou-se a inflação como presente na atualidade, e contabilistas e não contabilistas a percebem de forma discrepante. Os contabilistas acreditam que os balanços das empresas são afetados pela inflação e, de uma forma geral, não há concordância de que o fim da correção monetária de balanços foi oportuno. Acreditam, ainda, que a inflação causa distorção nas demonstrações contábeis das empresas e entendem como necessários mecanismos que transmitam as demonstrações contábeis os efeitos da inflação (VASCONCELOS et al., 2012).

Foram apontados por Rezende et al (2012) como fatores motivadores do processo de desinstitucionalização das práticas contábeis de correção monetária nas empresas brasileiras: (i) diminuição dos índices de inflação; (ii) mudança das leis sobre publicação de informação contábil corrigida; (iii) não exigência por parte do mercado financeiro desse tipo de informação; (iv) custos de manutenção da prática superiores aos benefícios da informação gerada;(v) surgimento de novas tecnologias contábeis; (vi) níveis de inflação no período (mês e ano) e (vii) harmonização internacional das práticas contábeis.

O patrimônio líquido, por previsão legal até 2007, e em alguns casos a partir daí, comportava uma conta denominada reserva de reavaliação. Tal conta decorre de uma nova avaliação não obrigatória do ativo da empresa. O valor do patrimônio líquido da empresa tem certa vinculação com seu valor de mercado, e o fato de uma empresa realizar ou não a reavaliação de seu ativo, não alterava essa vinculação. Comparando-se o valor do patrimônio líquido de uma empresa pelo seu valor original, de custo, com seu valor obtido por meio da correção monetária integral das demonstrações contábeis também não resultou em alguma alteração no conteúdo informacional do patrimônio líquido (BATISTELLA, 2011). 
A utilização de valores atualizados ou o reconhecimento das variações nos níveis gerais de preços nas demonstrações contábeis não fere princípios contábeis, particularmente o princípio do custo como base de valor e o princípio do denominador comum monetário. Pelo contrário, para que tais princípios fossem atendidos em sua plenitude as variações gerais de preços deveriam ser consideradas nas demonstrações contábeis. O não reconhecimento da inflação nas demonstrações contábeis pode alterar significativamente o resultado das empresas e, por consequência, o valor dos dividendos distribuídos, ainda que em períodos de baixa inflação. A influência da inflação não é sentida por todas as empresas da mesma forma, sendo que em alguns casos a empresa poderá deixar de pagar dividendos sobre lucros não reconhecidos prejudicando o acionista, enquanto em outros casos poderá pagar dividendos sobre lucros inexistentes prejudicando a saúde financeira da empresa no longo prazo (KLANN et al., 2007).

São consideradas economias hiperinflacionárias pelas normas contábeis aquelas que alcançam 100\% de inflação em um período de três anos. No Brasil, de 1996 a 2009, em nenhum triênio a inflação ficou nesse nível. Dentro desse período, o triênio com inflação acumulada mais alta foi o de 2001-2003 com 23\%. Nesse período os efeitos inflacionários não reconhecidos nas demonstrações contábeis se mostraram relevantes. As diferenças entre valores históricos e valores corrigidos do ativo permanente e do patrimônio líquido de empresas de energia elétrica mostraram-se estatisticamente significantes, evidenciando que a média dos valores sem correção monetária não é estatisticamente igual à média dos valores com a correção. $\mathrm{O}$ patrimônio líquido, no estudo em tela, apresentou-se com valores incompatíveis com aqueles que teria apresentado caso fosse utilizada uma moeda constante nas demonstrações contábeis, e nenhuma conta patrimonial não monetária retratou o que se propôs a retratar. O resultado do exercício, assim como o ROE, mostrou uma superavaliação do desempenho por apresentar resultados nominais superiores aos efetivos, demonstrando que a apuração de resultado a valor histórico se mostrou incompleta por ignorar a existência de lucro somente após a manutenção do valor real da empresa (MELO et al., 2011). 


\section{BASE DE DADOS PARA PESQUISA}

\subsection{Empresas selecionadas}

Foram selecionadas para o estudo as empresas que negociavam suas ações na Bolsa de Valores de São Paulo no final do ano de 2010. Como ponto de partida foi necessário definir quantas empresas negociavam seus títulos patrimoniais em bolsa nessa data.

A partir de uma relação de empresas disponível no site da BM\&FBovespa foi possível definir um ponto de início para essa tarefa. Havia, então, pouco mais de 500 empresas, porém dessa relação constavam empresas que passaram a negociar seus títulos patrimoniais na bolsa após a data de 31 de dezembro de 2010, assim como não figuravam mais companhias abertas que tinham deixado de negociar seus títulos patrimoniais até a data da consulta, mas que em 31 de dezembro de 2010 ainda o faziam. Para se conseguir uma relação atualizada das empresas é possível acessar o site da BM\&FBovespa, selecionar as opções: mercados, ações, empresas, e, por fim, empresas listadas. A que foi utilizada nesse estágio inicial está disponível no anexo 2 do presente trabalho.

Na sequência, foi solicitado à BM\&FBovespa uma relação das companhias abertas em 31 de dezembro de 2010. A instituição retornou a solicitação com um arquivo contendo diversas informações sobre companhias listadas, inclusive aquelas que negociavam seus títulos patrimoniais na data especificada. No entanto, o arquivo continha mais informações, como empresas que negociavam títulos em balcão organizado, balcão não organizado, fundos de investimento, o que gerou a necessidade de analisar individualmente as empresas para filtrar as informações.

A mensagem da instituição pela qual foi fornecida a relação das empresas figura no presente trabalho na seção de anexos, mais especificamente no anexo 1.

Com as informações disponibilizadas foram identificadas as companhias abertas, aqui consideradas empresas nacionais e igualmente as estrangeiras emissoras de Brazilian Depositary Receipts -BDRs, na data especificada. Em informativo da BM\&FBovespa, o número de companhias com essas características na data especificada era de 471, como demonstra a tabela abaixo. 
Tabela 5 - Companhias Abertas em 31 de dezembro de 2010

\begin{tabular}{|l|r|r|}
\hline Mercado & dez/10 Part. $(\%)^{*}$ \\
\hline Novo Mercado & 112 & $23,80 \%$ \\
\hline Nível 2 & 18 & $3,80 \%$ \\
\hline Nível 1 & 37 & $7,90 \%$ \\
\hline Básico e BDRs & 304 & $64,50 \%$ \\
\hline Total & $471^{*}$ & $100,00 \%$ \\
\hline
\end{tabular}

Fonte: BM\&FBovespa, 2010

Dessas 471 companhias, 8 não disponibilizaram suas demonstrações contábeis oportunamente, o que levou o presente trabalho a considerar as informações de 463 companhias abertas.

Dessas 463 companhias, as demonstrações contábeis de 47 delas estavam sendo consideradas duplamente por decorrência do procedimento de consolidação de demonstrações contábeis. Essas 47 companhias, então, tiveram suas informações contábeis retiradas do levantamento de dados, resultando em 416 companhias com demonstrações contábeis analisadas.

O patrimônio líquido dessas companhias foi decomposto em suas principais contas, de forma que fosse possível identificar o efeito das alterações introduzidas pela normatização contábil. Com a intenção de tornar essa identificação menos genérica, dividiu-se o total de 416 companhias em 8 setores com características similares, partindo-se da classificação setorial utilizada pela BM\&FBovespa, e presente nos dados fornecidos pela instituição.

Os setores que resultaram dessa divisão foram:

Quadro 2 - Setores utilizados de companhias abertas

\begin{tabular}{|c|l|}
\hline Setor & Composição \\
\hline 1 & Agricultura e setor alimentício \\
\hline 2 & Indústrias em geral \\
\hline 3 & Construção civil e exploração de imóveis \\
\hline 4 & Exploração de concessões \\
\hline 5 & Bancos e atividades financeiras \\
\hline 6 & Serviços em geral e transporte \\
\hline 7 & Petróleo e gás \\
\hline 8 & Comércio em geral \\
\hline
\end{tabular}


Com essa divisão buscou-se destacar setores específicos como construção civil, concessões, agricultura, atividades financeiras, assim como atividades relacionadas a petróleo e gás.

\subsection{Patrimônio líquido das empresas selecionadas}

O valor do patrimônio líquido das empresas selecionadas, muitas vezes possui componentes que não estavam presentes antes do processo de convergência de normas contábeis pelo qual o Brasil vem passando.

O levantamento dos valores contidos no patrimônio líquido das companhias abertas, doravante denominado neste trabalho de consolidado, permitiu apurar a composição desse grupo dentro dessas empresas. Com relação ao exercício de 2010, somando-se todas as companhias abertas, obteve-se um patrimônio líquido com a seguinte composição:

Tabela 6 - Patrimônio líquido de companhias abertas em 2010

\begin{tabular}{|l|r|r|}
\hline & Valor em R\$ mil & Participação \\
\hline Capital social & 855.370 .681 & $59,41 \%$ \\
\hline Reservas & 500.296 .198 & $34,75 \%$ \\
\hline Ações em tesouraria & -7.826 .380 & $-0,54 \%$ \\
\hline Prejuízos acumulados & -36.710 .431 & $-2,55 \%$ \\
\hline Ajuste de avaliação patrimonial & 49.550 .067 & $3,44 \%$ \\
\hline Outros resultados abrangentes & -8.953 .253 & $-0,62 \%$ \\
\hline Dividendo adicional proposto & 16.612 .611 & $1,15 \%$ \\
\hline Custos de captação & -544.619 & $-0,04 \%$ \\
\hline Remuneração baseada em ações & 926.977 & $0,06 \%$ \\
\hline Participação de não-controladores & & 41.163 .853 \\
\hline Total & & $4,94 \%$ \\
\hline
\end{tabular}

Considerando-se como componentes do patrimônio líquido itens que já eram utilizados, portanto, que não foram introduzidos na normatização contábil a partir dos pronunciamentos do CPC, obteve-se a seguinte composição do somatório de componentes de patrimônio líquido das companhias abertas: 
Tabela 7 - Patrimônio líquido de companhias abertas em 2010 apresentado no formato anterior

\begin{tabular}{lrr}
\hline & Valor em $\mathbf{R}$ mil & Participação \\
Capital social & 855.370 .681 & $65,24 \%$ \\
Reservas & 500.296 .198 & $38,16 \%$ \\
Ações em tesouraria & -7.826 .380 & $-0,60 \%$ \\
Prejuízos acumulados & -36.710 .431 & $-2,80 \%$ \\
& & \\
\hline Total & 1.311 .130 .068 & $100,00 \%$ \\
\hline
\end{tabular}

Com o ajuste realizado, houve uma redução no patrimônio líquido consolidado das companhias abertas. Esse ajuste consistiu em apresentar o patrimônio líquido de 2010 das companhias no padrão existente antes de 2010. Não houve a intenção aqui de se identificar exatamente o valor do patrimônio líquido que existiria em 31 de Dezembro de 2010 sem as alterações contábeis existentes até então, pois as mudanças são extensas e refletem em diversas partes das demonstrações contábeis. O ajuste citado consistiu na eliminação de itens do patrimônio líquido que não existiriam sem as alterações contábeis vigentes. Dos itens que deixaram de ser incluídos na somatória, dois se destacaram: o ajuste de avaliação patrimonial e a participação de acionistas não controladores.

O ajuste de avaliação patrimonial foi introduzido pela Lei no 11.638/2007, e é utilizado para o registro de valores que compõem o resultado das companhias, mas não o resultado do exercício. Essa conta é classificada dentro de "outros resultados abrangentes", tendo sua variação evidenciada na Demonstração de Resultados Abrangentes - DRA, e não na Demonstração de Resultado do Exercício - DRE.

A participação de acionistas não controladores, anteriormente às mudanças pela qual passou a contabilidade nacional, era classificada em um item à parte do balanço patrimonial, entre o patrimônio líquido e o passivo. Assim, essa participação não foi incorporada à contabilidade das companhias, mas passou a ser apresentada dentro do patrimônio líquido.

Pelos valores apresentados nas Tabelas 6 e 7, nota-se a diferença entre o patrimônio líquido consolidado com e sem os componentes introduzidos pelas alterações contábeis recentes. Houve uma redução de 8,9\% no valor do patrimônio líquido consolidado.

Partindo-se da premissa de que o valor do patrimônio líquido é um componente de significativa importância na contabilidade das empresas, assumindo um papel juntamente com 
o passivo, capaz de conduzir os usuários da informação contábil a uma série de conclusões acerca da entidade, uma alteração dessa magnitude pode resultar em alterações relacionadas às informações obtidas a partir do conjunto de demonstrações contábeis das empresas.

\subsection{Patrimônio líquido das empresas selecionadas por setor}

Continuando-se o detalhamento iniciado no item anterior, dividiu-se o grupo de 463 companhias abertas em 8 setores de acordo com as similaridades dos segmentos nos quais as companhias atuam.

O patrimônio líquido consolidado exposto no item 3.2 foi distribuído entre esses setores objetivando-se identificar particularidades inerentes aos setores.

Tabela 8 - Patrimônio líquido ajustado de companhias abertas em 2010

\begin{tabular}{|c|c|c|c|}
\hline & \multicolumn{3}{|c|}{ PL no formato } \\
\hline & PL publicado & anterior & Variação \\
\hline Setor 1 - Agricultura e setor alimentício & 90.207 .142 & 78.160 .569 & $-13,4 \%$ \\
\hline Setor 2 - Indústrias em geral & 254.368 .347 & 226.259 .731 & $-11,1 \%$ \\
\hline Setor 3 - Construção civil e exploração de imóveis & 54.050 .524 & 52.089 .248 & $-3,6 \%$ \\
\hline Setor 4 - Exploração de concessões & 292.297 .684 & 256.132 .866 & $-12,4 \%$ \\
\hline Setor 5 - Bancos e atividades financeiras & 367.527 .178 & 322.631 .310 & $-12,2 \%$ \\
\hline Setor 6 - Serviços em geral e transportes & 31.203 .009 & 29.844 .247 & $-4,4 \%$ \\
\hline Setor 7 - Petróleo e gás & 335.265 .678 & 331.550 .726 & $-1,1 \%$ \\
\hline Setor 8 - Comércio em geral & 14.966.144 & 14.461 .372 & $-3,4 \%$ \\
\hline Total & 1.439 .885 .705 & 1.311 .130 .068 & $-8,9 \%$ \\
\hline
\end{tabular}

Comparando-se o patrimônio líquido consolidado das companhias abertas consideradas com o patrimônio líquido dessas mesmas companhias abertas, porém no formato que teria sem as mudanças normativas, verificou-se uma redução de 8,9\% no total desse grupo. No entanto, a análise por setores demonstra que as alterações no patrimônio líquido afetaram as companhias de forma desigual. O setor 1 composto por companhias relacionadas à agricultura e setor alimentício, juntamente com os setores que compreenderam companhias relacionadas à concessão de serviços públicos, bancos e atividades financeiras e indústrias em geral situaram-se dentre os setores que mais apresentaram diferença entre o patrimônio líquido publicado e o patrimônio líquido apresentado no formato anterior.

Dentre os setores que menos sofreram influência, estiveram os setores de petróleo e gás e o de comércio em geral. 
Partiu-se da variação do patrimônio líquido consolidado, passando-se pela percepção de que o patrimônio líquido de setores diferentes foram afetados de forma diversa. No intuito de analisar os principais pontos que levaram a essa diferença, fez-se necessário o detalhamento ainda maior da composição do patrimônio líquido.

\subsection{Composição do patrimônio líquido das empresas selecionadas por setor}

O patrimônio líquido das empresas foi decomposto em alguns grupos principais: capital social, reservas, ações em tesouraria, prejuízos acumulados, ajuste de avaliação patrimonial, outros resultados abrangentes, dividendo adicional proposto, custos de captação, remuneração baseada em ações e participação de não controladores.

Parte desses grupos parciais passou a figurar no patrimônio líquido das empresas a partir das alterações contábeis iniciadas no exercício de 2008 e inseridas completamente a partir do exercício de 2010.

Para auxiliar na análise desses dados apresenta-se, na Tabela 9, o detalhamento, por setor, dos componentes do PL.

Tabela 9 - Patrimônio líquido das companhias detalhado por setores - R\$ mil

\begin{tabular}{|c|c|c|c|c|c|c|c|c|c|}
\hline Patrimônio líquido em R\$ & $\begin{array}{l}\text { Setor 1- } \\
\text { Agricultura } \\
\text { e setor } \\
\text { alimentício }\end{array}$ & $\begin{array}{c}\text { Setor 2- } \\
\text { Ind.aérea, } \\
\text { armas,munições, } \\
\text { metalurgia,itens } \\
\text { de consumo } \\
\text { em geral }\end{array}$ & $\begin{array}{c}\text { Setor 3- } \\
\text { Construção } \\
\text { civil, } \\
\text { exploração } \\
\text { de imóveis }\end{array}$ & $\begin{array}{c}\text { Setor } 4 \text { - } \\
\text { Serviços por } \\
\text { concessão }\end{array}$ & $\begin{array}{l}\text { Setor 5- } \\
\text { Bancose } \\
\text { atividades } \\
\text { financeiras }\end{array}$ & $\begin{array}{l}\text { Setor 6- } \\
\text { Serviços em } \\
\text { geral e de } \\
\text { transportes }\end{array}$ & $\begin{array}{c}\text { Setor } 7 \text { - } \\
\text { Petróleoe } \\
\text { gás }\end{array}$ & $\begin{array}{l}\text { Setor \&- } \\
\text { Comércio } \\
\text { em geral }\end{array}$ & Total \\
\hline Capital Social & 56.347 .629 & 123.542 .872 & 35.699 .475 & 148.093 .045 & 227.798 .853 & 27.863 .285 & 227.113.064 & 8.912 .459 & 855.370 .681 \\
\hline Reservas & 28.688 .437 & 119.835 .440 & 17.250 .265 & 111.762 .316 & 105.061 .472 & 5.965 .682 & 105.817 .341 & 5.915 .243 & 500.296 .198 \\
\hline Ações em tesouraria & -540.740 & -5.580 .915 & -109.258 & -237.511 & -917.575 & -229.244 & -939 & -210.198 & -7.826 .380 \\
\hline Prejuízos Acumulados & -6.334 .757 & -11.537 .666 & -751.235 & -3.484 .984 & -9.311 .440 & -3.755 .477 & -1.378 .740 & -156.132 & -36.710 .431 \\
\hline Ajuste de avaliação patrimonial & 2.698 .320 & 6.971 .761 & 525.471 & 8.416 .872 & 29.548 .903 & 931.878 & 494.171 & -37.309 & 49.550 .067 \\
\hline Outros resultados abrangentes & -2.479 .756 & -11.405 .434 & -3.384 & 1.976 .059 & 3.262 .275 & 31.593 & -336.240 & 1.634 & -8.953 .253 \\
\hline Dividendo adicional proposto & 4.410 .646 & 2.077 .571 & 18.633 & 6.430 .908 & 3.335 .327 & 102.150 & 0 & 237.376 & 16.612 .611 \\
\hline Custos de transação & -104.447 & -129.127 & -164.837 & -13.686 & 0 & -132.522 & 0 & 0 & -544.619 \\
\hline Remuneração baseada em ações & 448.528 & 136.245 & 110.904 & 14.410 & 8.010 & 150.035 & 0 & 58.845 & 926.977 \\
\hline Participação de não-controladores & 7.073 .282 & 30.457 .599 & 1.474 .489 & 19.340 .255 & 8.741 .353 & 275.628 & 3.557 .021 & 244.226 & 71.163 .853 \\
\hline Total do patrimônio líquido & 90.207 .142 & 254.368.347 & 54.050 .524 & 292.297 .684 & 367.527 .178 & 31.203 .009 & 335.265 .678 & 14.966 .144 & 1.439 .885 .705 \\
\hline
\end{tabular}

Com a intenção de evidenciar de maneira alternativa a composição do patrimônio líquido das companhias, foi elaborada a Tabela10, a seguir, com seus valores relativos. 
Tabela 10 - Patrimônio líquido das companhias detalhado por setores - \%

\begin{tabular}{|c|c|c|c|c|c|c|c|c|c|}
\hline Valores relativos & $\begin{array}{l}\text { Setor 1- } \\
\text { Agricultura } \\
\text { e setor } \\
\text { alimentício }\end{array}$ & $\begin{array}{c}\text { Setor 2- } \\
\text { Ind.aérea, } \\
\text { armas,muniçōes, } \\
\text { metalurgia,itens } \\
\text { de consumo } \\
\text { em geral }\end{array}$ & $\begin{array}{l}\text { Setor 3- } \\
\text { Construção } \\
\text { civil, } \\
\text { exploracãão } \\
\text { de imóveis }\end{array}$ & $\begin{array}{c}\text { Setor } 4 \text { - } \\
\text { Serviços por } \\
\text { concessão }\end{array}$ & $\begin{array}{l}\text { Setor 5- } \\
\text { Bancos e } \\
\text { atividades } \\
\text { financeiras }\end{array}$ & $\begin{array}{l}\text { Setor 6- } \\
\text { Serviços em } \\
\text { geral e de } \\
\text { transportes }\end{array}$ & $\begin{array}{l}\text { Setor 7. } \\
\text { Petróleo e } \\
\text { gás }\end{array}$ & $\begin{array}{l}\text { Setor 8- } \\
\text { Comércio } \\
\text { em geral }\end{array}$ & Total \\
\hline
\end{tabular}

\begin{tabular}{|c|c|c|c|c|c|c|c|c|c|}
\hline \multicolumn{10}{|l|}{ 'Patrimônio Líquido } \\
\hline Capital Social & $62 \%$ & $49 \%$ & $66 \%$ & $51 \%$ & $62 \%$ & $89 \%$ & $68 \%$ & $60 \%$ & $59 \%$ \\
\hline Reservas & $32 \%$ & $47 \%$ & $32 \%$ & $38 \%$ & $29 \%$ & $19 \%$ & $32 \%$ & $40 \%$ & $35 \%$ \\
\hline Ações em tesouraria & $-1 \%$ & $-2 \%$ & $0 \%$ & $0 \%$ & $0 \%$ & $-1 \%$ & $0 \%$ & $-1 \%$ & $-1 \%$ \\
\hline Prejuízos Acumulados & $-7 \%$ & $-5 \%$ & $-1 \%$ & $-1 \%$ & $-3 \%$ & $-12 \%$ & $0 \%$ & $-1 \%$ & $-3 \%$ \\
\hline Ajuste de avaliação patrimonial & $3 \%$ & $3 \%$ & $1 \%$ & $3 \%$ & $8 \%$ & $3 \%$ & $0 \%$ & $0 \%$ & $3 \%$ \\
\hline Outros resultados abrangentes & $-3 \%$ & $-4 \%$ & $0 \%$ & $1 \%$ & $1 \%$ & $0 \%$ & $0 \%$ & $0 \%$ & $-1 \%$ \\
\hline Dividendo adicional proposto & $5 \%$ & $1 \%$ & $0 \%$ & $2 \%$ & $1 \%$ & $0 \%$ & $0 \%$ & $2 \%$ & $1 \%$ \\
\hline Custos de transação & $0 \%$ & $0 \%$ & $0 \%$ & $0 \%$ & $0 \%$ & $0 \%$ & $0 \%$ & $0 \%$ & $0 \%$ \\
\hline Remuneração baseada em ações & $0 \%$ & $0 \%$ & $0 \%$ & $0 \%$ & $0 \%$ & $0 \%$ & $0 \%$ & $0 \%$ & $0 \%$ \\
\hline Participação de não-controladores & $8 \%$ & $12 \%$ & $3 \%$ & $7 \%$ & $2 \%$ & $1 \%$ & $1 \%$ & $2 \%$ & $5 \%$ \\
\hline Total do patrimônio líquido & $100 \%$ & $100 \%$ & $100 \%$ & $100 \%$ & $100 \%$ & $100 \%$ & $100 \%$ & $100 \%$ & $100 \%$ \\
\hline
\end{tabular}

A partir das tabelas apresentadas, é possível iniciar um processo de compreensão mais aprofundado acerca de questões relacionadas ao patrimônio líquido das companhias selecionadas.

\subsubsection{Capital social}

O capital social representa os recursos entregues às empresas pelos sócios ou acionistas, ou recursos gerados pela entidade e que foram formalmente incorporados ao capital social. Nas palavras de Iudícibus et al (2010, p.343), trata-se na verdade "de uma figura mais jurídica do que econômica, já que, do ponto de vista econômico, também os lucros não distribuídos, mesmo que ainda na forma de Reservas, representam uma espécie de investimento dos acionistas.” Dentro do patrimônio líquido há os valores disponibilizados pelos sócios assim como valores que representam resultados das empresas, e esses resultados podem ter sido apurados em exercícios encerrados ou, então, podem não ter sido ainda apurados em exercícios passados, compondo, assim, a parte do patrimônio líquido denominada de "outros resultados abrangentes".

O setor de empresas que demonstrou ter maior participação de capital social dentro do patrimônio líquido foi o de empresas de serviços e transporte, neste trabalho denominado de setor 6. Nesse setor, $89 \%$ do patrimônio líquido foi formado por capital social, e as reservas de lucro e de capital foram responsáveis por mais 19\% do total desse setor. Esse setor também foi o que apresentou relativamente o maior prejuízo acumulado, consumindo $12 \%$ do grupo. 
Uma alta participação de capital social e a alta proporção de prejuízos acumulados guardados no patrimônio líquido podem estar relacionadas. Isso porque à medida que os prejuízos são apurados, eles corroem os valores contidos em demais contas do grupo analisado, como prevê a legislação contábil vigente:

Art. 189. Do resultado do exercício serão deduzidos, antes de qualquer participação, os prejuízos acumulados e a provisão para o Imposto sobre a Renda.

Parágrafo único. o prejuízo do exercício será obrigatoriamente absorvido pelos lucros acumulados, pelas reservas de lucros e pela reserva legal, nessa ordem. (BRASIL, 1976)

Esse saldo, em tese, apareceria quando não há mais saldo nessas contas para realizar a absorção dos prejuízos apurados, passando, então, a existir saldo na conta redutora do patrimônio líquido de prejuízos acumulados.

Possivelmente, esse também é o motivo que faz com que o setor 6 , de empresas prestadoras de serviço e de transporte, seja dentre os setores estudados o que tem relativamente o menor valor de reservas.

\subsubsection{Reservas}

As reservas são componentes do patrimônio líquido que representam valores recebidos que não transitaram pelo resultado como receitas e nem representaram contrapartida de esforço da empresa em termos de bens ou prestação de serviços, nesse caso, denominadas reservas de capital ou, então, representam lucros obtidos pela empresa e que foram retidos com finalidade específica, nesse caso, denominadas reservas de lucro (IUDÍCIBUS et al., 2010).

O setor que apresentou relativamente o menor volume de reservas dentro de seu patrimônio líquido foi o setor 6, das empresas prestadoras de serviços e de transporte. Questão apresentada previamente no item anterior.

Dois setores destacaram-se com relação ao volume de reservas dentro do patrimônio líquido. Um deles foi o setor 2, composto por indústrias em geral e que apresenta reservas no valor de $47 \%$ de seu patrimônio líquido. O segundo deles foi o setor 8 , composto por empresas comerciais e que apresentou $40 \%$ de seu patrimônio líquido composto por reservas. 
Dentro do setor das indústrias, foi possível perceber companhias com valores significativos dentro do grupo e que têm reservas superiores ao seu capital social.

Tabela 11 - Reservas das empresas do setor 2: indústrias em geral

\begin{tabular}{|c|c|c|c|c|}
\hline Companhia & $\begin{array}{c}\text { Capital Social } \\
\text { R\$ mil }\end{array}$ & $\begin{array}{c}\text { Reservas } \\
\text { R\$ mil }\end{array}$ & $\begin{array}{l}\text { Reservas } \\
\text { \% do PL }\end{array}$ & $\begin{array}{l}\text { Total PL } \\
\text { R\$ mil }\end{array}$ \\
\hline ALPARGATAS S.A. & 444.243 & 904.529 & $67 \%$ & 1.348 .073 \\
\hline KLABIN S.A. & 1.500 .000 & 2.539 .015 & $49 \%$ & 5.154 .502 \\
\hline LITEL PARTICIPACOES S.A. & 7.106 .481 & 12.892 .258 & $65 \%$ & 19.875 .375 \\
\hline VALE S.A. & 50.000 .000 & 76.481 .739 & $66 \%$ & 116.326 .864 \\
\hline VICUNHA SIDERURGIA S.A. & 1.181 .499 & 2.094 .462 & $27 \%$ & 7.854 .723 \\
\hline Total das cinco empresas & 60.232 .223 & 94.912 .003 & $63 \%$ & 150.559 .537 \\
\hline Total do setor 2 & 123.542 .872 & 119.835 .440 & $47 \%$ & 254.368.347 \\
\hline
\end{tabular}

Das 99 empresas que compuseram o setor 2 formado por indústrias em geral, cinco delas já representaram quase metade do patrimônio líquido do grupo todo, e essas cinco tinham reservas superiores aos respectivos capitais sociais. Dessas cinco, três tinham reservas que representavam mais de $60 \%$ dos respectivos patrimônios líquidos e todas as cinco apresentaram valor de reservas superior ao do capital social. Respondem também por quase metade do capital social e por $79 \%$ do total de reservas do setor.

A maior parte das reservas, no caso dessas empresas, é formada por reservas de lucros, em especial reservas para expansão, como é o caso da Vale que tinha, no final de 2010, o montante de $\mathrm{R} \$ 65,6$ bilhões nessa modalidade de reservas.

A companhia Litel, empresa de participações, tem por objetivo principal a participação direta e indireta na Valepar, empresa não caracterizada como companhia aberta, fazendo-se supor que suas informações possivelmente provenham de maneira substancial da companhia aberta Vale.

Na companhia Alpargatas a maior parte das reservas são compostas por reservas de lucros. Na companhia Klabin quase a totalidade das suas reservas é composta por reservas de lucros, assim como na companhia Vicunha Siderurgia.

Pelas atividades envolvidas, contatou-se a importância das reservas com a intenção de preservar a capacidade das companhias em investir e continuar gerando resultados, sendo o investimento relevante na própria atividade uma característica desse grupo. 
O setor 8 formado por empresas comerciais, também, destacou-se na questão relacionada à participação relativa das reservas dentro do patrimônio líquido. Esse grupo é composto por empresas comerciais e é esperado que os motivos que os leve ao acúmulo das reservas possam ser diferentes daqueles apresentados pelo setor 2 relativo a indústrias em geral. A Tabela 12 apresenta algumas empresas do setor 8 que têm valores significativos de reservas no patrimônio líquido assim como mais reservas do que capital social em seu patrimônio líquido.

Tabela 12 - Reservas das empresas do setor 8: empresas comerciais

\begin{tabular}{|l|r|r|r|r|}
\hline & $\begin{array}{c}\text { Capital Social } \\
\text { R\$ mil }\end{array}$ & $\begin{array}{c}\text { Reservas } \\
\text { R\$ mil }\end{array}$ & $\begin{array}{c}\text { Reservas } \\
\text { \% do PL }\end{array}$ & $\begin{array}{r}\text { Total PL } \\
\text { R\$ mil }\end{array}$ \\
\hline DROGASIL & 285.400 & 312.281 & $52 \%$ & 598.617 \\
\hline DUFRY A.G. & 274.071 & 1.692 .234 & $117 \%$ & 1.450 .945 \\
\hline HYPERMARCAS S.A. & 3.321 .195 & 1.687 .620 & $33 \%$ & 5.059 .091 \\
\hline LOJAS AMERICANAS S.A. & 285.054 & 319.641 & $58 \%$ & 550.678 \\
\hline LOJAS RENNER S.A. & 408.734 & 415.195 & $41 \%$ & 1.021 .308 \\
\hline SARAIVA S.A. LIVREIROS EDITORES & 190.978 & 212.886 & $50 \%$ & 424.464 \\
\hline & & & & $\mathbf{5 1 \%}$ \\
\hline Total das seis empresas & $\mathbf{4 . 4 8 0 . 0 3 2}$ & $\mathbf{4 . 3 2 7 . 5 7 6}$ & $\mathbf{8 . 5 0 6 . 4 8 6}$ \\
\hline Total do setor 8 & $\mathbf{8 . 9 1 2 . 4 5 9}$ & $\mathbf{5 . 9 1 5 . 2 4 3}$ & $\mathbf{4 0 \%}$ & $\mathbf{1 4 . 9 6 6 . 1 4 4}$ \\
\hline
\end{tabular}

As companhias desse setor também têm característica de constituir reservas para investimentos futuros, como são os casos das empresas de varejo Americanas e Renner. No entanto, dentro desse setor se destaca o fato de empresas terem aberto capital recentemente, o que fez com que suas reservas de capital ficassem com saldos altos devido à abertura de capital, uma vez que o valor do ágio na emissão de ações é classificado como reserva de capital. Esse é o caso da Hypermarcas e da Dufry, que sozinhas, respondem por mais de 57\% das reservas desse grupo, e a maior parte de suas reservas se refere a reservas de capital decorrente de abertura de capital. Pode-se, assim, observar que no caso do setor de comércio, não somente a intenção de reter recursos para futuros investimentos foi responsável pela participação significativa das reservas dentro do patrimônio líquido do setor.

\subsubsection{Ações em tesouraria}

As companhias são vedadas de negociar suas próprias ações de maneira geral, o que não implica vedação de aquisição dessas ações para fins específicos. A Lei no 6.404/1976 prevê esses fins específicos em seu artigo 30:

Art. 30. A companhia não poderá negociar com as próprias ações.

$\S 1^{\circ}$ Nessa proibição não se compreendem:

a) as operações de resgate, reembolso ou amortização previstas em lei; 
b) a aquisição, para permanência em tesouraria ou cancelamento, desde que até o valor do saldo de lucros ou reservas, exceto a legal, e sem diminuição do capital social, ou por doação;

c) a alienação das ações adquiridas nos termos da alínea b e mantidas em tesouraria;

d) a compra quando, resolvida a redução do capital mediante restituição, em dinheiro, de parte do valor das ações, o preço destas em bolsa for inferior ou igual à importância que deve ser restituída.

(BRASIL, 1976).

As ações próprias da companhia por ela adquiridas são denominadas ações em tesouraria, e enquanto estiverem em poder da empresa emitente não concedem direito a voto. A aquisição de ações de emissão própria e sua alienação são consideradas transações de capital, assim o resultado obtido não transita pelo resultado do exercício. O preço de aquisição das ações não poderá ser superior ao valor de mercado dessas ações (IUDÍCIBUS et al., 2010).

A CVM regulamentou a previsão legal de transações com ações emitidas pela própria companhia pela Instrução CVM no 10 de 14 de fevereiro de 1980, que previa que as companhias não poderiam manter em tesouraria mais de 5\% de cada classe de ações em circulação no mercado, incluindo-se, nesse total, as ações existentes, mantidas em tesouraria por sociedades controladas e coligadas. Posteriormente, a Instrução CVM no 268 de 13 de novembro de 1997 aumentou esse limite para $10 \%$.

O setor2composto por indústrias em geral destacou-se no tocante à participação de ações em tesouraria com relação ao total do patrimônio líquido, sendo que as ações em tesouraria representaram $2 \%$ do patrimônio líquido do grupo. Esse setor é composto por 99 empresas, mas duas delas foram responsáveis pelo realce recebido pelo grupo nesse sentido. Ao relacionar o valor das ações em tesouraria com os respectivos valores de capital social foi possível observar a representatividade dessa conta sob outro enfoque, à medida que no caso de uma das duas empresas apresentadas na Tabela 13, a Vale, o valor das ações em tesouraria correspondeu a $9,6 \%$ do valor do capital social.

Tabela 13 - Ações em tesouraria das empresas do setor 2: indústrias em geral

\begin{tabular}{|c|c|c|c|c|}
\hline Companhia & $\begin{array}{c}\text { Capital Social } \\
\mathrm{R} \$ \text { mil }\end{array}$ & $\begin{array}{c}\text { Ações em } \\
\text { Tesouraria } R \$ \text { mil }\end{array}$ & $\begin{array}{c}\text { Ações em } \\
\text { Tesouraria \% do PL }\end{array}$ & $\begin{array}{c}\text { Total PL } \\
\text { R\$ mil }\end{array}$ \\
\hline EMBRAER S.A. & 4.789.617 & -320.250 & $-6 \%$ & 5.217 .757 \\
\hline VALE S.A. & 50.000 .000 & -4.826 .127 & $-4 \%$ & 116.326 .864 \\
\hline Total das duas empresas & 54.789 .617 & -5.146 .377 & $-4 \%$ & 121.544 .621 \\
\hline Total do setor 2 & 123.542 .872 & -5.580 .915 & $-2 \%$ & 254.368.347 \\
\hline
\end{tabular}


O valor relativo às ações em tesouraria nesses dois casos corresponde a uma parcela considerável do patrimônio líquido, acima dos $2 \%$ apresentados pela média do grupo. Pelas demonstrações contábeis foi possível identificar um programa de recompra de ações utilizando reservas patrimoniais com o objetivo de mantê-las para futura alienação ou cancelamento. $\mathrm{O}$ valor apresentado pode levar a alguma dúvida com relação ao limite que as companhias podem manter de ações próprias em tesouraria, que equivale a $10 \%$ das ações em circulação. No entanto, nos dois casos a quantidade de ações próprias em tesouraria está abaixo desse limite, apesar do valor em Reais despertar eventualmente essa questão.

A empresa Vale tinha em 31 de dezembro de 2010 um total de 5.365.304.100 de ações emitidas, sendo 3.256.724.482 ordinárias e 2.108.579.618 preferenciais. Possuía em tesouraria, nessa data, 99.650 mil ações preferenciais e 47.375 mil ações ordinárias, valores esses abaixo do limite estabelecido pelo seu Conselho de Administração em setembro de 2010.

A empresa Embraer mantinha em 31 de dezembro de 2010 a quantidade de 16.800 .000 ações ordinárias em tesouraria, de um total de 740.465 .044 ações ordinárias emitidas. Do total das ações que compunham o capital social na data, 49,6\% estavam sendo negociadas na BM\&FBovespa, e 50,4\% estavam sendo negociadas sob a forma de American Depositary Shares (ADS) na New York Stock Exchange (NYSE). Essa recompra de ações foi realizada conforme regras aprovadas pelo Conselho de Administração em reunião de 07 de dezembro de 2007, e as ações foram adquiridas até 04 de abril de 2008.

Há um alinhamento entre as ações das duas companhias nessa questão, o que pode ser explicado pelo fato de serem empresas com ações de alta liquidez e com porte significativo, estando dentre as maiores companhias do país. Tais condições viabilizam esses programas de recompra em situações que sejam oportunos. Essas recompras se deram em período de redução de preços das ações e agindo, dessa maneira, a empresa tem como retirar capital próprio de circulação a um preço menor do que faria em época com preços em alta.

Nesse tópico ficou demonstrada a relevância de questões relacionadas ao patrimônio líquido das empresas, pelo volume financeiro envolvido em ações em tesouraria, nesses casos específicos. Em quantidade de ações, as companhias mantiveram-se dentro dos limites previstos pela CVM, porém em Reais, em um dos casos, o valor das ações em tesouraria 
chega a ser superior ao próprio capital social, o que pode ser explicado pela diferença que existe entre valor contábil do patrimônio líquido se incluindo o capital social, e o valor de mercado de companhias abertas. E sendo assim, a relevância dá-se, nessa questão, principalmente, em função da possibilidade das companhias, não somente as aqui apresentadas e nesse período, mas em geral, negociarem seus próprios títulos patrimoniais e, nessa negociação, o resultado apurado não transitará pelo resultado do exercício por se tratar de transação de capital. Dessa forma, com resultados positivos e negativos não transitando pela demonstração de resultado do exercício, torna necessário um conhecimento mais amplo dos temas resultado e patrimônio líquido, para que seja percebido o efetivo impacto das transações das companhias em seus patrimônios, ressaltando-se que podem sofrer influência de mais de uma origem - resultado abrangente de maneira ampla, resultado do exercício de maneira mais restrita e transações de capital.

\subsubsection{Prejuízos acumulados}

Uma empresa ao apurar prejuízo no exercício classificará esse valor no patrimônio líquido na conta de prejuízos acumulados. No entanto, nem sempre a conta de prejuízos terá utilização quando a empresa apura prejuízo no exercício.

Isso ocorre porque o prejuízo apurado no exercício deverá, ao ser registrado no patrimônio líquido da entidade, primeiramente ser absorvido pelas reservas de lucros, de acordo com o disposto na Lei $n^{\circ}$ 6.404/1976:

Art. 189. Do resultado do exercício serão deduzidos, antes de qualquer participação, os prejuízos acumulados e a provisão para o Imposto sobre a Renda.

Parágrafo único. O prejuízo do exercício será obrigatoriamente absorvido pelos lucros acumulados, pelas reservas de lucros e pela reserva legal, nessa ordem. (BRASIL, 1976)

O artigo 200 da Lei no 6.404/1976 prevê, ainda, com relação à compensação contábil de prejuízos:

Art. 200. As reservas de capital somente poderão ser utilizadas para:

I - absorção de prejuízos que ultrapassarem os lucros acumulados e as reservas de lucros (artigo 189, parágrafo único);

[...] (BRASIL, 1976). 
Como resultado dessa previsão legal, conclui-se que a conta de prejuízos acumulados somente figurará no patrimônio líquido caso não existam reservas de lucros e/ou de capital passíveis de compensação suficientes para efetivar a compensação prevista.

O artigo da referida lei em seu parágrafo único chega a elencar a conta de lucros acumulados, ainda que essa conta não mais figure no artigo 178 da mesma lei como sendo uma das contas componentes do patrimônio líquido. Essa alteração foi promovida pela Lei no $11.638 / 20$. Tal previsão legal aplica-se às sociedades por ações e não às empresas limitadas, como elucida a Orientação OCPC 02 em seu item de número 115. A mesma orientação esclarece ainda em seu item de número 116 que a conta de lucros acumulados continua nos planos de contas, e que "seu uso continua a ser feito para receber o resultado do exercício, as reversões de determinadas reservas, os ajustes de exercícios anteriores, para distribuir os resultados nas suas várias formas e destinar valores para reservas de lucros." (COMITÊ DE PRONUNCIAMENTOS CONTÁBEIS, 2009a).

O grupo que apresentou maior representatividade na conta de prejuízos acumulados foi o setor 6, composto por empresas de serviços em geral e de transportes. A Tabela 14 evidencia companhias desse grupo com participação significativa de prejuízos acumulados contidos em seus patrimônios líquidos.

Tabela 14- Prejuízos acumulados das empresas do setor 6: serviços em geral e transportes

\begin{tabular}{|c|c|c|c|c|}
\hline Companhia & $\begin{array}{c}\text { Capital Social } \\
\text { R\$ mil }\end{array}$ & $\begin{array}{c}\text { Prejuízos } \\
\text { acumulados } \\
\text { R\$ mil }\end{array}$ & $\begin{array}{l}\text { Prejuízos } \\
\text { acumulados } \\
\% \text { do PL }\end{array}$ & $\begin{array}{c}\text { Total PL } \\
\mathrm{R} \$ \text { mil }\end{array}$ \\
\hline HOPI HARI S.A. & 275.105 & -245.719 & $-199 \%$ & 123.353 \\
\hline HOTEIS OTHON S.A. & 31.984 & -316.807 & $823 \%$ & -38.510 \\
\hline IDEIASNET S.A. & 241.546 & -121.207 & $-91 \%$ & 132.899 \\
\hline MAORI S.A. & 79.783 & -112.754 & $342 \%$ & -32.971 \\
\hline NET SERVICOS DE COMUNICACAO S.A. & 5.599 .320 & -1.937 .822 & $-51 \%$ & 3.814 .666 \\
\hline SAO PAULO TURISMO S.A. & 120.911 & -175.053 & $-225 \%$ & 77.898 \\
\hline SAUIPE S.A. & 66.394 & -74.854 & $885 \%$ & -8.460 \\
\hline TELEC BRASILEIRAS S.A. TELEBRAS & 419.455 & -449.266 & $2010 \%$ & -22.352 \\
\hline Total das oito empresas & 6.834 .498 & -3.433 .482 & $-85 \%$ & 4.046.523 \\
\hline Total do setor 6 & 27.863 .285 & -3.755 .477 & $-12 \%$ & 31.203 .009 \\
\hline
\end{tabular}

O setor é formado por 42 empresas, e com a tabela apresentando dados de oito delas é possível perceber que são responsáveis por mais de $90 \%$ do prejuízo do grupo, ainda que em valor de patrimônio líquido não tenham representado mais de $13 \%$ do valor do total do grupo, 
e o capital social tenha representado pouco menos de $25 \%$ do total apurado para o grupo. $\mathrm{O}$ valor do prejuízo do grupo corresponde a $12 \%$ do patrimônio líquido e a 13\% do capital social desse mesmo grupo.

Há situações nas quais o valor da conta de prejuízos acumulados foi superior ao valor apresentado no capital social das respectivas companhias.

A exposição da normatização a respeito da conta de prejuízos acumulados direciona à inferência de que em empresas nas quais existe saldo nessa conta as reservas de lucros e de capital tendem a ser menos representativas do que seriam, fato decorrente da compensação contábil realizada.

Nessas circunstâncias se torna previsível que o setor6, formado por empresas prestadoras de serviços em geral e atuantes no segmento de transportes, que apresentou relativamente a maior proporção de prejuízos acumulados também tenha sido o grupo que apresentou relativamente a menor proporção de reservas contidas no patrimônio líquido, como foi exposto na Tabela 10, por serem dois fatores intimamente ligados e até excludentes.

\subsubsection{Ajuste de avaliação patrimonial}

A conta de ajuste de avaliação patrimonial foi originalmente inserida no patrimônio líquido por intermédio da Lei no 11.638/2007, como disposto abaixo:

Art. 182. A conta do capital social discriminará o montante subscrito e, por dedução, a parcela ainda não realizada.

\section{$[\ldots]$}

$\S 3^{\circ}$ Serão classificadas como ajustes de avaliação patrimonial, enquanto não computadas no resultado do exercício em obediência ao regime de competência, as contrapartidas de aumentos ou diminuições de valor atribuído a elementos do ativo ( $\$$ o do art. 177, inciso I do caput do art. 183 e $\S 30$ do art. 226 desta Lei) e do passivo, em decorrência da sua avaliação a preço de mercado. [...] (BRASIL, 2007).

Posteriormente, o texto do citado artigo teve sua redação parcialmente alterada pela Lei no 11.941/2009:

Art. 182. A conta do capital social discriminará o montante subscrito e, por dedução, a parcela ainda não realizada. 


\section{$[\ldots]$}

$\S 3^{\circ}$ Serão classificadas como ajustes de avaliação patrimonial, enquanto não computadas no resultado do exercício em obediência ao regime de competência, as contrapartidas de aumentos ou diminuições de valor atribuídos a elementos do ativo e do passivo, em decorrência da sua avaliação a valor justo, nos casos previstos nesta Lei ou, em normas expedidas pela Comissão de Valores Mobiliários, com base na competência conferida pelo § 3o do art. 177 desta Lei. (Redação dada pela Lei $\mathrm{n}^{\circ} 11.941$, de 2009)

[...] (BRASIL, 2009).

A conta de ajustes de avaliação patrimonial registra valores que representam contrapartidas de ativos e passivos, decorrente de avaliação a valor justo, mas que não transitaram ainda pelo resultado do exercício em obediência ao regime de competência. São exemplos de valores registrados nessa conta as variações de preço de mercado dos instrumentos financeiros quando destinados à venda futura, e diferenças de ativos e passivos a preço de mercado nas reorganizações societárias. Pode ter saldo credor ou devedor e não pode ser confundida com uma conta de reserva por não registrar valores que transitaram pelo resultado. De uma forma geral, os valores registrados nessa conta são transferidos para o resultado do exercício à medida que ativos e passivos que os originaram forem sendo realizados (IUDÍCIBUS et al., 2010).

O Comitê de Pronunciamentos Contábeis na Orientação OCPC 02 (2009a) esclarece que a avaliação de ativos a valor justo, que origina o ajuste de avaliação patrimonial em parte dos casos, somente pode ser realizada em ativos a serem utilizados futuramente pela empresa.

$\mathrm{Na}$ avaliação realizada no patrimônio líquido das empresas, constatou-se que o setor que apresentou maior representatividade da conta de ajuste de avaliação patrimonial foi o de número 5, composto por empresas do setor financeiro, no qual a referida conta representa $8 \%$ do valor do patrimônio líquido consolidado do setor.

O detalhamento de companhias que mais influenciaram para esse resultado nesse grupo está demonstrado na Tabela 15: 
Tabela 15 - Ajustes de avaliação patrimonial das empresas do setor 5: bancos e atividades financeiras

\begin{tabular}{|c|c|c|c|c|}
\hline Companhia & $\begin{array}{c}\text { Capital Social } \\
\text { R\$ mil }\end{array}$ & $\begin{array}{c}\text { Ajuste de avaliação } \\
\text { patrimonial } \\
\text { R\$ mil }\end{array}$ & $\begin{array}{c}\text { Ajuste de } \\
\text { avaliação patrimonial } \\
\text { \% do PL }\end{array}$ & $\begin{array}{c}\text { Total PL } \\
\text { R\$ mil }\end{array}$ \\
\hline BCO SANTANDER (BRASIL) S.A. & 62.828 .201 & 283.498 & $0 \%$ & 64.876 .985 \\
\hline ARAUCARIA PARTICIPACOES S.A. & 724.443 & 79.746 & $13 \%$ & 629.924 \\
\hline BNDES PARTICIPACOES S.A. - BNDESPAR & 46.304 .356 & 29.203 .362 & $34 \%$ & 86.501 .946 \\
\hline BRADESPAR S.A. & 3.000 .000 & -287.680 & $-5 \%$ & 6.385 .356 \\
\hline BMFBOVESPA S.A. BOLSA VALORES MERC FUT & 2.540 .239 & -88.680 & $0 \%$ & 19.419.048 \\
\hline CIA HABITASUL DE PARTICIPACOES & 127.182 & 161.871 & $31 \%$ & 524.288 \\
\hline CIA SEGUROS ALIANCA DA BAHIA & 100.000 & 19.068 & $11 \%$ & 171.955 \\
\hline CTX PARTICIPAÇÕES S.A. & 80.694 & -68.833 & $-19 \%$ & 358.755 \\
\hline OPPORTUNITY ENERGIA E PARTICIPACOES S.A. & 12.382 & 59.347 & $84 \%$ & 70.981 \\
\hline PARCOM PARTICIPACOES S.A. & 203 & 15.663 & $42 \%$ & 37.682 \\
\hline Total das dez empresas & 115.717 .700 & $29.377 .362^{\prime}$ & $16 \%$ & 178.976 .920 \\
\hline Total do setor 5 & 227.798 .853 & 29.548 .903 & $8 \%$ & 367.527.178 \\
\hline
\end{tabular}

Das companhias averiguadas, uma delas é responsável por $98 \%$ do valor relativo a ajustes de avaliação patrimonial do grupo, sendo que esse grupo é composto por 100 companhias. Há companhias que têm a conta de ajuste de avaliação patrimonial correspondendo a uma parcela do patrimônio líquido que não pode ser considerada baixa, chegando a mais de $50 \%$ desse grupo nas respectivas companhias.

A conta de ajuste de avaliação patrimonial tem uma característica que merece ser ressaltada, e decorre da sua natureza. Por refletir valores que ainda não transitaram pelo resultado, que por sua vez decorrem de avaliação a valor justo de componentes patrimoniais, é possível que parte do valor representado nessa conta nunca venha a se transformar efetivamente em resultado, pois pode acontecer de ser anulado em exercícios subsequentes.

Dessa maneira, a conta de ajuste de avaliação patrimonial tem um componente que merece atenção especial, uma vez que sua essência não pode ser confundida com outras contas do patrimônio líquido, como contas de reservas de lucros ou reservas de capital, por exemplo. Tem maior volatilidade e sua variação pode ser acompanhada pela Demonstração de Resultados Abrangentes, o que enfatiza a relevância de tal demonstração dado o volume que essa conta pode assumir como visto na Tabela 10.

Do valor registrado em ajustes de avaliação patrimonial, essencialmente foram encontradas participações acionárias mantidas para venda, prática utilizada pela companhia BNDES Participações, e que pelo fato dessa companhia apresentar em valores absolutos mais de $98 \%$ 
do total registrado no grupo sob esse título, acaba por influenciá-lo. Nas demais companhias também prevalecem nessa conta as participações acionárias em coligadas ou controladas, classificadas como títulos mobiliários mantidos para venda como origem dos ajustes de avaliação patrimonial.

A natureza da origem dos valores de ajustes de avaliação patrimonial está alinhada com as características do grupo, formado basicamente por empresas financeiras e de participações, e a representatividade dessa conta dentro do patrimônio líquido se apresentou relativamente alta em casos específicos. Embora, na média do grupo, 7\% do patrimônio líquido foi representado por essa conta, houve casos nos quais essa mesma conta passou de um terço do patrimônio líquido da companhia, incluindo-se, nessa observação, o caso da empresa que sozinha apresentou mais de $98 \%$ do valor de ajuste de avaliação patrimonial do grupo, que foi a companhia BNDES Participações.

\subsubsection{Outros resultados abrangentes}

O resultado abrangente compreende mutações no patrimônio líquido durante um período que não estão relacionadas às transações com sócios na qualidade de proprietários, e compreende todos os componentes da demonstração de resultados e também da demonstração dos resultados abrangentes, de acordo com o Pronunciamento Técnico CPC 26 (COMITÊ DE PRONUNCIAMENTOS CONTÁBEIS, 2009b).

Dessa forma, conclui-se que o resultado se divide em resultado que transitou pela demonstração de resultado do período e resultado que não transitou pela demonstração de resultado do período. Dentro da modalidade que não transitou pela demonstração de resultado do período estão contidos itens classificados em ajustes de avaliação patrimonial, que se enquadram nessa definição. Entretanto, no presente trabalho, optou-se por dividir esses resultados que não transitaram pela demonstração do resultado do período em ajustes de avaliação patrimonial e em outros resultados abrangentes, pela especificidade da conta de ajustes de avaliação patrimonial, bem como pelo fato dessa conta estar prevista individualmente na legislação federal.

No estudo realizado, foi observado que dois grupos apresentaram contas classificadas em outros resultados abrangentes com valores relativos que sobressaíram com relação aos demais 
que foram: o setor 1, composto por empresas do setor agrícola e alimentício e o setor 2, composto por indústrias em geral.

O setor 1 formado por empresas dos setores agrícola e alimentício apresentou contas em outros resultados abrangentes que representaram 3\% do patrimônio líquido, mas contas que consumiram o valor do patrimônio líquido, o que significa dizer que apresentaram saldo negativo. Esse setor foi composto por 29 empresas e, dessas, as que mais contribuíram para esse destaque foram as apresentadas na Tabela 16:

Tabela 16- Outros resultados abrangentes das empresas do setor 1: agrícola e alimentício

\begin{tabular}{|l|c|r|r|r|}
\hline & $\begin{array}{c}\text { Capital Social } \\
\text { R\$ mil }\end{array}$ & $\begin{array}{c}\text { Outros } \\
\text { resultados abrangentes } \\
\text { Com mil }\end{array}$ & $\begin{array}{c}\text { Outros } \\
\text { resultados abrangentes } \\
\text { \% do PL }\end{array}$ & $\begin{array}{c}\text { Total PL } \\
\text { R\$ mil }\end{array}$ \\
\hline CIA BEBIDAS DAS AMERICAS - AMBEV & 7.613 .780 & -2.148 .598 & $-9 \%$ & 24.564 .842 \\
\hline JBS S.A. & 18.046 .067 & -1.632 .370 & $-9 \%$ & 18.694 .849 \\
\hline MARFRIG ALIMENTOS S/A & 4.061 .478 & 340.939 & $5 \%$ & 6.496 .413 \\
\hline SLC AGRICOLA S.A. & 557.434 & 989.291 & $53 \%$ & 1.874 .993 \\
\hline Total das quatro empresas & & & $-\mathbf{5 \%}$ & $\mathbf{5 1 . 6 3 1 . 0 9 7}$ \\
\hline Total do setor 1 & $\mathbf{3 0 . 2 7 8 . 7 5 9}$ & $\mathbf{- 2 . 4 5 0 . 7 3 8}$ & $\mathbf{- 3 \%}$ & $\mathbf{9 0 . 2 0 7 . 1 4 2}$ \\
\hline
\end{tabular}

As quatro companhias apresentadas representam quase integralmente os valores de outros resultados abrangentes, aproximadamente $57 \%$ do patrimônio líquido e pouco mais de metade do valor do capital social apresentados pelo grupo. Percebeu-se que a composição dos valores de outros resultados abrangentes se deu principalmente em decorrência de ajustes de conversão de balanços de investidas no exterior, com exceção da companhia SLC Agrícola S.A. que apresentou, no ano de 2010, unicamente, movimentação decorrente de hedge de fluxo de caixa.

O setor 2 composto por indústrias em geral apresentou contas em outros resultados abrangentes que representaram $4 \%$ do patrimônio líquido, mas contas que consumiram o valor do patrimônio líquido, o que significa dizer que, assim como aconteceu no setor 1 de empresas dos setores agrícola e alimentício, apresentaram saldo negativo. O setor 2 de indústrias em geral foi composto por 99 empresas e, dessas, as que mais contribuíram para esse destaque foram as apresentadas na Tabela 17: 
Tabela 17- Outros resultados abrangentes das empresas do setor 2: indústrias em geral

\begin{tabular}{|c|c|c|c|c|}
\hline Companhia & $\begin{array}{c}\text { Capital Social } \\
\text { R\$ mil }\end{array}$ & $\begin{array}{c}\text { Outros } \\
\text { resultados abrangentes } \\
\mathbf{R} \$ \mathbf{~ m i l}\end{array}$ & $\begin{array}{l}\text { resultados } \\
\text { abrangentes } \\
\text { \% do PL }\end{array}$ & $\begin{array}{c}\text { Total PL } \\
\text { R\$ mil }\end{array}$ \\
\hline BOMBRIL S.A. & 795.142 & -133.537 & $113 \%$ & -117.894 \\
\hline MAHLE-METAL LEVE S.A. & 966.255 & 121.777 & $9 \%$ & 1.347 .836 \\
\hline LITEL PARTICIPACOES S.A. & 7.106 .481 & -1.714 .543 & $-9 \%$ & 19.875.375 \\
\hline VALE S.A. & 50.000 .000 & -9.512 .225 & $-8 \%$ & 116.326 .864 \\
\hline WHIRLPOOL S.A. & 1.085 .793 & -99.559 & $-6 \%$ & 1.719 .270 \\
\hline Total das cinco empresas & 59.953 .671 & $-11.338 .087^{\prime \prime}$ & $-8 \%$ & 139.151.451 \\
\hline Total do setor 2 & 123.542 .872 & -11.405 .434 & $-4 \%$ & 254.368.347 \\
\hline
\end{tabular}

As cinco companhias apresentadas representam quase integralmente os valores de outros resultados abrangentes, mais de $48 \%$ do capital social e $54 \%$ do valor do patrimônio líquido apresentado pelo grupo. Percebeu-se que a composição dos valores de outros resultados abrangentes se deu, em sua grande maioria, por valores acumulados de conversão de balanços de investidas no exterior.

Nessas cinco empresas, o valor de outros resultados abrangentes é composto por ajustes acumulados de conversão. No caso das companhias analisadas, o valor apresentado sob esse título não pode ser considerado pequeno, representando na média $8 \%$ do patrimônio líquido. Como em todas elas, a origem do valor é a mesma, o ajuste de conversão em investimentos estrangeiros, percebe-se uma característica desse tipo de conta, que é sua apresentação de forma significativa em demonstrações contábeis de companhias que têm investimentos relevantes no exterior.

Os dois grupos que apresentaram maior valor relativo a outros resultados abrangentes registrados no patrimônio líquido, mesmo com de atividades distintas, têm em comum a característica de que tais valores decorrem quase que unicamente de ajustes acumulados de conversão, sendo assim resultados gerados pela conversão de balanço de empresas coligadas ou controladas estabelecidas fora do país. Há casos em que essa parcela do patrimônio líquido assume papel de destaque, como é o caso da companhia Bombril, na qual não fosse tal valor, o patrimônio líquido do período não teria ficado negativo.

O fato do valor dos ajustes acumulados de conversão ser negativo ocorreu em função da variação da taxa de câmbio, mais especificamente valorização do Real. Por informações obtidas no site do Banco Central do Brasil, um dólar norte-americano valia R \$ 1,7412 no final 
do exercício de 2009, enquanto passou a valer $\mathrm{R} \$ 1,6662$ no final de 2010. Essa taxa foi apresentada a título de ilustração com a intenção de demonstrar a valorização do real nesse período, uma vez que nas demonstrações contábeis de companhias investidas no exterior diversas moedas eventualmente podem ter sido utilizadas.

O valor apresentado em outros resultados abrangentes como delineado neste estudo merece atenção, já que, em sua maioria, ficou evidenciado que é composto por ajustes acumulados de conversão de balanços de companhias investidas no exterior, e esse resultado pode nunca vir a ser realizado. Para isso, caso hipoteticamente as taxas de câmbio realizassem movimento contrário na mesma intensidade que ocorreu durante o exercício de 2010, o resultado apurado nesse exercício relativo à conversão de demonstrações contábeis poderia anular ainda que não integralmente ou, até mesmo, ultrapassar aquele que foi apurado no decorrer do exercício de 2010.

As contas relativas a outros resultados abrangentes podem conter resultados que nunca comporão de forma efetiva, ainda que não definitiva, o patrimônio líquido das companhias, como acontece com o resultado apurado do exercício.

\subsubsection{Dividendo adicional proposto}

Os dividendos são os lucros apurados pelas companhias que são distribuídos regularmente aos sócios ou acionistas. No caso de companhias abertas essa distribuição é regulamentada. Com a intenção de não deixar que essa distribuição oscile de acordo com as conveniências existentes, a legislação prevê que uma parcela mínima dos dividendos deve ser distribuída aos acionistas caso o estatuto da companhia seja omisso nesse ponto. Dessa maneira, é possível a existência de uma previsibilidade com relação ao pagamento de dividendos, que estará regulado pelo estatuto da companhia ou, então, pela legislação vigente, no caso a Lei no $6.404 / 1976$.

Contudo, é possível que a entidade decida distribuir aos acionistas além do estritamente previsto pelo estatuto ou legislação. Historicamente, não havia no ordenamento contábil distinção quanto à contabilização do dividendo que seria pago por decorrência de aplicação de regra previamente estabelecida e aquele que seria pago decorrente de liberalidade da companhia, sendo ambos considerados como passivo. Este segundo, de acordo com as normas contábeis vigentes, carece das qualidades previstas pelo Comitê de Pronunciamentos 
Contábeis para que possa ser considerado como passivo, como expresso no Pronunciamento Técnico CPC 25:

Passivo é uma obrigação presente da entidade, derivada de eventos já ocorridos, cuja liquidação se espera que resulte em saída de recursos da entidade capazes de gerar benefícios econômicos.

Evento que cria obrigação é um evento que cria uma obrigação legal ou não formalizada que faça com que a entidade não tenha nenhuma alternativa realista senão liquidar essa obrigação. (COMITÊ DE PRONUNCIAMENTOS CONTÁBEIS, 2009f).

A parcela dos dividendos que a companhia opta por liberalidade distribuir não pode ser considerada logo que proposta como uma obrigação. Isso porque não é nesse momento uma obrigação da entidade, e não faz com que a única alternativa realista da entidade seja liquidar essa obrigação. Caso a assembleia de acionistas não aprove tal proposta, essa parcela adicional de dividendos não será distribuída. Como as demonstrações contábeis costumam ser publicadas antes da assembleia dos acionistas, nessa ocasião, o dividendo adicional ainda não pode ser contabilizado como passivo, o que faz com que seja contabilizado em uma conta específica ainda dentro do patrimônio líquido com denominação que faça menção a essa condição, e comumente recebe o nome de dividendo adicional proposto.

O Comitê de Pronunciamentos Contábeis em seu Pronunciamento Técnico CPC 24 discorre sobre a previsão da contabilização dos dividendos adicionais propostos:

\section{Dividendos}

12. Se a entidade declarar dividendos aos detentores de instrumentos de patrimônio (como definido no Pronunciamento Técnico CPC 39 - Instrumentos Financeiros: Apresentação) após o período contábil a que se referem as demonstrações contábeis, a entidade não deve reconhecer esses dividendos como passivo ao final daquele período.

13. Se forem declarados dividendos após o período contábil a que se referem as demonstrações contábeis, mas antes da data da autorização de emissão dessas demonstrações esses dividendos não devem ser reconhecidos como passivo ao final daquele período, em virtude de não atenderem aos critérios de obrigação presente na data das demonstrações contábeis como definido no Pronunciamento Técnico CPC 25 - Provisões, Passivos Contingentes e Ativos Contingentes. Tais dividendos devem ser divulgados nas notas explicativas em conformidade com o Pronunciamento Técnico CPC 26 - Apresentação das Demonstrações Contábeis. (COMITÊ DE PRONUNCIAMENTOS CONTÁBEIS, 2009e).

Dentre as companhias analisadas, dois setores destacaram-se em relação ao valor registrado sob esse título contido no patrimônio líquido, o setor 1, composto por empresas do setor alimentício e de agricultura, e o setor 4, composto por empresas concessionárias de serviços públicos. O setor 8 composto por empresas comerciais, apesar de constar na Tabela 10 
também com $2 \%$, calculando-se com maior precisão e sem arredondamento apresentou 1,6\% de seu PL representado por dividendos adicionais propostos, assim não ficando entre os dois setores com maior representatividade nesse quesito.

O setor 4 composto por 71 companhias concessionárias de serviços públicos teve $2 \%$ de seu patrimônio líquido representado por valores relacionados a dividendos adicionais propostos, e dentro desse grupo, as companhias que relativamente apresentaram maior valor sob esse título são apresentadas na Tabela 18:

Tabela 18- Dividendos adicionais propostos das empresas do setor 4: concessionárias de serviços públicos

\begin{tabular}{|c|c|c|c|c|}
\hline Companhia & $\begin{array}{c}\text { Capital Social } \\
\mathbf{R} \$ \text { mil }\end{array}$ & $\begin{array}{c}\text { Dividendo } \\
\text { adicional } \\
\text { proposto } \\
\text { R\$ mil }\end{array}$ & $\begin{array}{l}\text { Dividendo } \\
\text { adicional } \\
\text { proposto } \\
\% \text { do PL }\end{array}$ & $\begin{array}{c}\text { Total PL } \\
\text { R\$ mil }\end{array}$ \\
\hline AES SUL DISTRIB GAUCHA DE ENERGIA S.A. & 433.236 & 169.515 & $21 \%$ & 802.377 \\
\hline CIA PAULISTA DE FORCA E LUZ & 109.810 & 232.526 & $29 \%$ & 808.683 \\
\hline CIA PIRATININGA DE FORCA E LUZ & 70.587 & 132.682 & $33 \%$ & 396.907 \\
\hline CIA ENERGETICA DO CEARA - COELCE & 442.946 & 240.804 & $18 \%$ & 1.360 .772 \\
\hline CONCESSIONARIA ROD.OESTE SP VIAOESTE S.A & 139.763 & 125.798 & $31 \%$ & 408.001 \\
\hline TELEFÔNICA BRASIL S.A & 6.575 .480 & 1.694 .099 & $15 \%$ & 11.667.114 \\
\hline Total das seis empresas & 7.771.822 & 2.595 .424 & $17 \%$ & 15.443.854 \\
\hline Total do setor 4 & 148.093 .045 & 6.430 .908 & $2 \%$ & 292.297.684 \\
\hline
\end{tabular}

Das companhias presentes nesse setor, foram selecionadas, na Tabela 18, as que têm valor de dividendos adicionais propostos em proporção de $15 \%$ ou mais de seus respectivos PLs. Foram seis companhias com tais características. Em média, essas seis companhias tinham 17\% do PL sob forma de dividendo adicional proposto, chegando, em um caso específico, a um terço do PL. Esses valores demonstram a representatividade do que é distribuído ao acionista nesse segmento específico, lembrando que essa é uma parcela do dividendo, aquela que está no patrimônio líquido, portanto, ainda sem a aprovação da assembleia. Há outra parte do dividendo que não figura no patrimônio líquido, a parte do dividendo obrigatório, já explicada anteriormente.

As empresas concessionárias de serviços públicos têm objetivo e campo de atuação bem definidos, ao contrário do que pode ocorrer em outras atividades com menos regulação governamental. Uma empresa concessionária não tem a mesma necessidade de reserva de recursos para expansão do que um banco ou uma empresa varejista, por exemplo, que costumam adquirir participações ou, até mesmo, incorporar empresas no país e no exterior. No caso de empresas concessionárias, os investimentos são previstos e realizados levando-se 
em consideração a concessão objeto de sua atividade principal. Esse motivo leva as companhias a uma tendência de distribuição de dividendos superior à media encontrada no mercado. Na Tabela 18apresentada foi possível identificar empresas que possuíam em 31 de dezembro de 2010, aproximadamente, um terço de seu patrimônio líquido na forma de dividendos a serem distribuídos após a aprovação da assembleia de acionistas.

O setor 1, composto por 29 companhias do setor alimentício e agrícola, teve $5 \%$ de seu patrimônio líquido representado por valores relacionados a dividendos adicionais propostos, e dentro desse grupo, apenas, três companhias apresentaram valores registrados sob esse título, que foram:

Tabela 19 - Dividendos adicionais propostos das empresas do setor 1: agrícola e alimentício

\begin{tabular}{|c|c|c|c|c|}
\hline Companhia & $\begin{array}{c}\text { Capital Social } \\
\text { R\$̦ mil }\end{array}$ & $\begin{array}{c}\text { Dividendo } \\
\text { adicional } \\
\text { proposto } \\
\mathrm{R} \$ \mathrm{mil}^{\mathrm{m}}\end{array}$ & $\begin{array}{c}\text { Dividendo } \\
\text { adicional } \\
\text { proposto } \\
\% \text { do PL }\end{array}$ & $\begin{array}{l}\text { Total PL } \\
\text { R\$ mil }\end{array}$ \\
\hline CIA BEBIDAS DAS AMERICAS - AMBEV & 7.613 .780 & 4.290 .306 & $17 \%$ & 24.564 .842 \\
\hline CIA BRASILEIRA DE DISTRIBUICAO & 5.579 .259 & 86.755 & $1 \%$ & 9.583 .770 \\
\hline M.DIAS BRANCO S.A. IND COM DE ALIN & 746.529 & 33.585 & $2 \%$ & 1.760 .517 \\
\hline Total das três empresas & 13.939.568 & 4.410 .646 & $12 \%$ & 35.909 .129 \\
\hline Total do setor 1 & 56.347 .629 & 4.410.646 & $5 \%$ & 90.207.142 \\
\hline
\end{tabular}

Das únicas três companhias que apresentaram valores relacionados a dividendos adicionais propostos nesse grupo, apenas, uma foi responsável pelo valor relativo de dividendos adicionais propostos do grupo ser superior aos demais grupos, a Ambev, que tinha, em 31 de dezembro de 2010, 17\% de seu patrimônio líquido na forma de dividendo adicional proposto. As outras duas companhias apresentaram valores relativos baixos, e as outras 26 companhias do grupo sequer apresentaram valores referentes a dividendos adicionais no patrimônio líquido, o que indica que a Ambev pode ser considerada uma exceção nesse grupo com relação a esse quesito.

Essa exceção, possivelmente, pode ser explicada pelo porte da companhia que, em 2010, operava em 14 países, era a quarta maior cervejaria do mundo e líder do mercado latino americano em volume. Uma companhia desse porte já se situa em uma fase na qual há certa estabilização, o que não significa que não há necessidades de investimento, mas que relativamente poderia ser inferior às necessidades de empresas menores. 
O dividendo adicional proposto é um valor que figura, temporariamente, no patrimônio líquido, pois em questão de dias ou meses a contar da publicação das demonstrações contábeis ele deve ser realocado ao passivo por adquirir status de obrigação assim que aprovado pela assembleia de acionistas e, historicamente, é o que tem acontecido. Ao menos com relação às empresas analisadas nesse estudo, ao se propor um determinado valor de dividendos, a intenção foi de efetivamente proceder a distribuição. Todos os valores relacionados à distribuição de dividendos adicionais das companhias listadas nas Tabelas 18 e 19 foram confirmados nas demonstrações contábeis do exercício subsequente, e nenhum deles sofreu qualquer tipo de anulação ou reversão.

Assim, essa conta merece atenção por significar efetivamente, na grande maioria dos casos, um passivo que está temporariamente hospedado no patrimônio líquido das companhias.

\subsubsection{Custos de transação}

Os custos de transação presentes no patrimônio líquido das companhias refletem os valores suportados por elas quando da emissão de títulos patrimoniais. A partir das demonstrações contábeis relativas ao exercício de 2008 esses valores passaram a figurar como contas redutoras do patrimônio líquido das companhias, não mais sendo amortizados no resultado.

Esses gastos configuram uma transação de capital, e não são encargos da empresa relacionados à sua atividade operacional. É "uma transação de capital entre a empresa e os sócios, que redunda num ingresso líquido de recursos, estes sim reconhecidos como aumento líquido de capital.” (IUDÍCIBUS et al., 2010, p.347).

Pela natureza desses gastos, essa conta de transação de capital aparece como redutora do patrimônio líquido, e em montante que reflete uma pequena parte do valor dos títulos patrimoniais emitidos. Logo, seus valores são relativamente pequenos com relação ao total do patrimônio líquido.

Como esse tratamento passou a ser dado às emissões a partir de 2008, ainda é reduzido o número de empresas que apresenta essa conta. Dentre os grupos estudados, aquele que apresentou a conta de custos de transação em valor relativo mais significativo foi o setor 6 , composto por companhias prestadoras de serviço em geral e de transporte. 
Dos oito setores avaliados nesse estudo, três não apresentaram nenhuma empresa com saldo na conta de custos de transação no patrimônio líquido.

Dentre as empresas do setor 6 uma única companhia apresentou valor nessa conta:

Tabela 20- Custos de transação das empresas do setor 6: serviços em geral

\begin{tabular}{|c|c|c|c|c|}
\hline Companhia & $\begin{array}{c}\text { Capital Social } \\
\text { R\$ mil }\end{array}$ & $\begin{array}{c}\text { Custos de } \\
\text { transação } \\
\text { R\$ mil }\end{array}$ & $\begin{array}{l}\text { Custos de } \\
\text { transação } \\
\% \text { do PL }\end{array}$ & $\begin{array}{l}\text { Total PL } \\
\text { R\$ mil }\end{array}$ \\
\hline GOL LINHAS AEREAS INTELIGENTES S.A. & 2.315 .655 & -132.522 & $-5 \%$ & 2.929 .169 \\
\hline Total da empresa & 2.315.655 & -132.522 & $-5 \%$ & 2.929 .169 \\
\hline Total do setor 6 & 27.863.285 & -132.522 & $0 \%$ & 31.203 .009 \\
\hline
\end{tabular}

O valor apresentado por essa única companhia do setor 6 relacionado a empresas prestadoras de serviço em geral e de transporte não foi suficiente para que no setor o valor se mostrasse relevante, o que não se confirma ao se analisar individualmente essa companhia. O seu patrimônio líquido teve $5 \%$ de seu valor reduzido por consequência da evidenciação desses custos de transação no PL. Pela forma anterior de contabilização, o valor também seria retirado do patrimônio líquido, porém isso seria feito de forma gradual e reduziria as reservas de lucros por ter transitado nas contas de resultado dos respectivos exercícios.

O setor 3 composto por empresas do segmento de construção civil e exploração de imóveis foi o segundo grupo que apresentou maiores valores relativos de custos de transação.

Tabela 21- Custos de transação das empresas do setor 3: construção civil e exploração de imóveis

\begin{tabular}{|c|c|c|c|c|}
\hline Companhia & $\begin{array}{c}\text { Capital } \\
\text { Social } \\
\text { R\$ mil }\end{array}$ & $\begin{array}{c}\text { Custos de } \\
\text { transação } \\
\text { R\$ mil }\end{array}$ & $\begin{array}{c}\text { Custos de } \\
\text { transação } \\
\% \text { do PL }\end{array}$ & $\begin{array}{c}\text { Total PL } \\
\text { R\$ mil }\end{array}$ \\
\hline ALIANSCE SHOPPING CENTERS S.A. & 916.342 & -23.468 & $-2 \%$ & 1.165 .900 \\
\hline BR MALLS PARTICIPACOES S.A. & 2.561 .195 & -39.879 & $-1 \%$ & 5.789 .398 \\
\hline BR PROPERTIES S.A. & 1.569 .935 & -25.698 & $-1 \%$ & 2.709 .470 \\
\hline EVEN CONSTRUTORA E INCORPORADORA S.A. & 1.083 .266 & -15.775 & $-1 \%$ & 1.409 .837 \\
\hline HELBOR EMPREENDIMENTOS S.A. & 490.941 & -13.236 & $-2 \%$ & 727.827 \\
\hline MRV ENGENHARIA E PARTICIPACOES S.A. & 2.350 .012 & -25.765 & $-1 \%$ & 3.052 .750 \\
\hline MULTIPLAN - EMPREEND IMOBILIARIOS S.A. & 1.761 .662 & -21.016 & $-1 \%$ & 2.965 .451 \\
\hline Total das sete empresas & 10.733 .353 & -164.837 & $-1 \%$ & 17.820 .633 \\
\hline Total do setor 3 & 35.699 .475 & -164.837 & $0 \%$ & 54.050 .524 \\
\hline
\end{tabular}

As sete empresas apresentadas na Tabela 21 representam a totalidade dos valores de custos de transação apurados nas companhias desse grupo. Há mais companhias que apresentam informações relacionadas a custo de captação neste setor do que no setor 6 de empresas 
prestadoras de serviços em geral e de transporte apresentado anteriormente. Contudo, neste setor, os valores relativos são inferiores, ficando em torno de $1 \%$ a $2 \%$ do PL das companhias.

Somando-se os custos de transação das empresas dos setores 6 e 3, das Tabelas 20 e 21, são apresentados os custos de transação relativos a $54 \%$ do total de custos de transação apresentado pelas companhias abertas relativos ao exercício de 2010.

Considerando-se o total de companhias abertas e dos valores de transação de capital já ocorridos, o valor apresentado nessa conta específica do capital social ainda é pouco expressivo, embora seja necessário relatar que em casos isolados esse valor pode atingir um percentual considerável do patrimônio líquido, como é o caso da companhia GOL que apresentou, em 2010, um valor de custos de transação equivalente a $5 \%$ de seu patrimônio líquido.

Esse tratamento aos gastos, na emissão de títulos patrimoniais, surgiu a partir de 2008, o que explica o baixo valor relativo da conta de custos de transação no patrimônio líquido, assim como o reduzido número de companhias que apresenta a referida conta, e possivelmente deixará de ser assim à medida que novas emissões de títulos patrimoniais forem ocorrendo.

\subsubsection{Pagamentos baseados em ações}

Serviços e produtos recebidos por uma entidade podem, em alguns casos, ter a previsão de liquidação por meio de títulos patrimoniais. Nesse caso, há duas possibilidades: a primeira, o registro do valor a ser liquidado no passivo, e isso ocorrerá nos casos em que os serviços ou produtos são adquiridos em transação com pagamento baseado em ações liquidadas em caixa. A segunda possibilidade consiste no registro do valor a ser liquidado em conta de patrimônio líquido, e ocorrerá se os serviços ou produtos forem recebidos em transação com pagamento baseado em instrumentos patrimoniais (COMITÊ DE PRONUNCIAMENTOS CONTÁBEIS, 2010b).

A segunda possibilidade é a que interessa ao presente estudo, por estar relacionada a uma conta do patrimônio líquido.

Essa conta do patrimônio líquido se assemelha mais a uma Reserva de Capital do que uma Reserva de Lucro, por isso deve ser apresentada juntamente com as Reservas de Capital ou, 
então, em separado. Na segunda hipótese não há previsão legal expressa, o que não impede a existência de respaldo legal para esse tratamento, que é logrado indiretamente pela previsão da Lei no 6.404/1976 com alterações da Lei no 11.941/2009 no sentido de determinar que as novas normas contábeis emitidas pela CVM fossem no sentido de convergência às normas internacionais de contabilidade (IUDÍCIBUS et al., 2010).

Igualmente o ocorrido no item anterior com relação aos custos de transação, nesse item, as companhias, também, apresentaram valores relativamente baixos, sendo que um dos grupos não apresentou valor algum em seu patrimônio líquido relacionado a pagamento baseado em ações. Ainda assim, dois grupos apresentaram valores para pagamento baseado em ações que representaram aproximadamente $0,5 \%$ do patrimônio líquido do grupo, e são dos oito setores os que apresentaram valores relativos mais elevados.

O primeiro deles foi o setor 1, composto por empresas relacionadas à agricultura e ao setor alimentício. Nesse grupo, composto por vinte e nove empresas, apenas, quatro delas apresentaram de maneira separada valores vinculados a pagamento baseado em ações. São elas:

Tabela 22- Pagamento baseado em ações das empresas do setor 1: agrícola e alimentício

\begin{tabular}{|c|c|c|c|c|}
\hline Companhia & $\begin{array}{c}\text { Capital Social } \\
\text { R\$ mil }\end{array}$ & $\begin{array}{c}\text { Pagamento } \\
\text { baseado } \\
\text { em ações } \\
\text { R\$ mil }\end{array}$ & $\begin{array}{l}\text { Pagamento } \\
\text { baseado } \\
\text { em ações } \\
\% \text { do PL }\end{array}$ & $\begin{array}{c}\text { Total PL } \\
\text { R\$ mil }\end{array}$ \\
\hline CIA BEBIDAS DAS AMERICAS - AMBEV & 7.613 .780 & 332.248 & $1 \%$ & 24.564 .842 \\
\hline CIA BRASILEIRA DE DISTRIBUICAO & 5.579 .259 & 111.145 & $1 \%$ & 9.583 .770 \\
\hline M.DIAS BRANCO S.A. IND COM DE ALIM & 746.529 & 1.186 & $0 \%$ & 1.760 .517 \\
\hline MONTICIANO PARTICIPACOES S.A. & 137.545 & 3.949 & $1 \%$ & 274.300 \\
\hline Total das quatro empresas & 14.077.113 & 448.528 & $1 \%$ & 36.183.429 \\
\hline Total do setor 1 & 56.347 .629 & 448.528 & $0 \%$ & 90.207 .142 \\
\hline
\end{tabular}

Das quatro empresas, duas delas apresentaram valores absolutos altos, mas em termos relativos não foi observada disparidade entre as quatro empresas. Nas notas explicativas das quatro companhias foram encontradas descrições dos planos de remuneração baseada em ações ou opções a executivos, administradores e/ou funcionários.

O segundo setor que apresentou valor relacionado a pagamento baseado em ações próximo a $0,5 \%$ do patrimônio líquido foi o setor 6 , composto por companhias prestadores de serviços 
em geral e de transportes. Nesse setor foram identificadas oito companhias que apresentaram no patrimônio líquido valores relacionados a pagamento baseado em ações. São elas:

Tabela 23- Pagamento baseado em ações das empresas do setor 6: serviços em geral e transportes

\begin{tabular}{|c|c|c|c|c|}
\hline Companhia & $\begin{array}{c}\text { Capital Social } \\
\text { R\$ mil }\end{array}$ & $\begin{array}{l}\text { Pagamento } \\
\text { baseado } \\
\text { em ações } \\
\text { R\$̣ mil }\end{array}$ & $\begin{array}{c}\text { Pagamento } \\
\text { baseado } \\
\text { em ações } \\
\% \text { do PL }\end{array}$ & $\begin{array}{l}\text { Total PL } \\
\text { R\$ mil }\end{array}$ \\
\hline BHG S.A. - BRAZIL HOSPITALITY GROUP & 640.775 & 2.515 & $0 \%$ & 638.199 \\
\hline FLEURY S.A. & 832.058 & 1.195 & $0 \%$ & 1.011 .803 \\
\hline GOL LINHAS AEREAS INTELIGENTES S.A. & 2.315 .655 & 43.727 & $1 \%$ & 2.929 .169 \\
\hline LOCALIZA RENT A CAR S.A. & 601.708 & 7.436 & $1 \%$ & 898.742 \\
\hline SANTOS BRASIL PARTICIPACOES S.A. & 1.042 .070 & 24.872 & $2 \%$ & 1.213.709 \\
\hline TAMS.A. & 819.892 & 51.667 & $2 \%$ & 2.627.391 \\
\hline TEMPO PARTICIPACOES S.A. & 534.067 & 11.553 & $4 \%$ & 295.160 \\
\hline TOTVS S.A. & 406.489 & 7.070 & $1 \%$ & 631.576 \\
\hline Total das oito empresas & 7.192.714 & $150.035^{\prime}$ & $1 \%$ & 10.245.749 \\
\hline Total do setor 6 & 27.863.285 & 150.035 & $0 \%$ & 31.203 .009 \\
\hline
\end{tabular}

Das oito empresas que apresentaram no patrimônio líquido valores relacionados a pagamento baseado em ações, três delas sobressaíram-se apresentando um valor relativo um pouco maior do que as demais. A que apresentou maior valor relativo foi a companhia Tempo Participações S.A. que atua participando de sociedades que exercem atividades de gestão de soluções para empresas e pessoas nos mercados de seguros e serviços assistenciais e, aproximadamente, $4 \%$ de seu patrimônio líquido era representado por valores relacionados a pagamento baseado em ações. Duas outras companhias que apresentaram valores relativos superiores às demais do grupo foram a Santos Brasil Participações S.A., empresa que participa de outras empresas e explora comercialmente instalações portuárias e retroportuárias e soluções logísticas integradas, com a movimentação de contêineres e afins, e a Tam S.A., companhia de transporte aéreo.

Nas notas explicativas das oito companhias foram encontradas descrições dos planos de remuneração baseada em ações ou opções a executivos, administradores e/ou funcionários.

Assim como o observado no item anterior, relativo a custos de transação, a quantidade de companhias e os valores identificados são relativamente pequenos considerando-se os demais detalhamentos que têm sido feitos no presente estudo. Ao contrário do que é de possível ocorrência com o tema de custos de transação, no qual há uma tendência de aumento do número de empresas que apresentam tais valores com o passar do tempo, uma vez que essa conta decorre de custos originados pela emissão de títulos patrimoniais e todas as companhias 
analisadas nesse estudo emitiram e podem vir a emitir novamente esses títulos. No caso de pagamento baseado em ações, a dependência está mais vinculada à cultura das companhias e formas de remuneração de colaboradores adotadas, de forma que não seria possível traçar uma relação da quantidade de empresas que apresentam tais valores com o tempo decorrido ou a decorrer.

\subsubsection{Participação de acionistas não controladores}

A parcela de capital social detida por acionistas que individualmente não conseguem deliberar pela companhia é representada pela conta de participação de acionistas não controladores. Em períodos anteriores à adoção das normas do Comitê de Pronunciamentos Contábeis, a participação de não controladores era divulgada em grupo apresentado entre o patrimônio líquido e o passivo exigível, como pode ser averiguado pela Deliberação no 488/2005 da Comissão de Valores Mobiliários:

\footnotetext{
64. No mínimo, o balanço patrimonial deve incluir rubricas que apresentem os montantes das principais contas ou grupo de contas, se aplicável, em ordem decrescente de liquidez ou exigibilidade, que normalmente inclui o seguinte:

No ativo (segregando o ativo circulante dos demais ativos):

$[\ldots]$

No Passivo (segregando o passivo circulante dos demais passivos):

[...]

Participação de acionistas não controladores

No Resultado de Exercícios Futuros

$[\ldots]$

No patrimônio líquido:

[...] (COMISSÃO DE VALORES MBILIÁRIOS, 2005).
}

A normatização emanada pelo Conselho Federal de Contabilidade previa de maneira similar, ao estipular que "a participação dos não controladores no patrimônio líquido das entidades controladas deve ser destacada em grupo isolado no balanço patrimonial consolidado, imediatamente antes do patrimônio líquido." (CONSELHO FEDERAL DE CONTABILIDADE, 1993, p.3; 2002, p.7). A partir de 2009, a participação de sócios não controladores passou a figurar dentro do patrimônio líquido do balanço patrimonial consolidado, porém separada da participação dos sócios controladores (CONSELHO FEDERAL DE CONTABILIDADE， 2009; COMITÊ DE PRONUNCIAMENTOS CONTÁBEIS, 2009b). E seguindo, na mesma linha, regula atualmente a Comissão de Valores Mobiliários:

54. O balanço patrimonial deve apresentar, respeitada a legislação, no mínimo, as seguintes contas: 


\section{$[\ldots]$ \\ (q) participação de não controladores apresentada de forma destacada dentro do patrimônio líquido; e \\ [...] (COMISSÃO DE VALORES MOBILIÁRIOS, 2011).}

O valor referente à participação de não controladores, em si, não sofreu alterações, o que foi modificado é sua classificação dentro do patrimônio líquido. O valor existia e não figurava formalmente dentro do denominado capital próprio, apesar de conceitualmente o ser.

Os grupos analisados que apresentaram maior participação relativa dessa conta foram os setores 1, 2 e 4, compostos por companhias do setor alimentício e agrícola, do setor de indústrias em geral e setor de serviços por concessão, respectivamente.

O grupo que apresentou maior participação relativa da participação de não controladores foi o setor 2 composto por indústrias em geral, com montante equivalente a $12 \%$ do patrimônio líquido do grupo. As empresas desse setor que mais contribuíram para essa participação foram:

Tabela 24- Participação de não controladores das empresas do setor 2: indústrias em geral

\begin{tabular}{|c|c|c|c|c|}
\hline Companhia & $\begin{array}{c}\text { Capital Social } \\
\text { R\$ mil }\end{array}$ & $\begin{array}{c}\text { Participação de } \\
\text { não controladores } \\
\text { R\$ mil }\end{array}$ & $\begin{array}{c}\text { Participação de } \\
\text { não controladores } \\
\text { \% do PL }\end{array}$ & $\begin{array}{c}\text { Total PL } \\
\text { R\$ mil }\end{array}$ \\
\hline EMBRAER S.A. & 4.789 .617 & 171.621 & $3 \%$ & 5.217.757 \\
\hline IOCHPE MAXION S.A. & 263.280 & 81.358 & $12 \%$ & 679.255 \\
\hline KLABIN S.A. & 1.500 .000 & 160.417 & $3 \%$ & 5.154 .502 \\
\hline LITEL PARTICIPACOES S.A. & 7.106 .481 & 1.092 .175 & $5 \%$ & 19.875.375 \\
\hline METALURGICA GERDAU S.A. & 6.881 .998 & 10.460 .212 & $57 \%$ & 18.289 .929 \\
\hline RANDON S.A. IMPLEMENTOS E PARTI & 730.000 & 445.697 & $28 \%$ & 1.617.742 \\
\hline SUZANO HOLDING S.A. & 1.018 .820 & 5.950 .585 & $68 \%$ & 8.762 .166 \\
\hline USINAS SID DE MINAS GERAIS S.A.-U! & 12.150 .000 & 1.596 .838 & $8 \%$ & 19.029.437 \\
\hline VALE S.A. & 50.000 .000 & 4.208 .860 & $4 \%$ & 116.326 .864 \\
\hline VICUNHA SIDERURGIA S.A. & 1.181 .499 & 4.169 .986 & $53 \%$ & 7.854 .723 \\
\hline WEMBLEY SOCIEDADE ANONIMA & 250.000 & 1.806 .335 & $81 \%$ & 2.228 .975 \\
\hline WETZEL S.A. & 47.147 & 748 & $35 \%$ & 2.162 \\
\hline Total das doze empresas & 85.918 .842 & 30.144 .832 & $15 \%$ & 205.038.887 \\
\hline Total do setor 2 & 123.542 .872 & 30.457 .599 & $12 \%$ & 254.368.347 \\
\hline
\end{tabular}

A Tabela 24 demonstra que doze empresas apresentam quase que a totalidade do valor de participação de não controladores do setor 2 inteiro, apesar de representarem pouco menos de $70 \%$ do capital desse grupo que é composto por 99 companhias. 
No patrimônio líquido consolidado desse grupo foi identificado que $12 \%$ do total era representado por valores relacionados à participação de acionistas não controladores, o que já demonstra a relevância dessa conta dentro do patrimônio líquido. Ao se identificar companhias nas quais mais da metade ou, até mesmo, dois terços do patrimônio líquido é representado por uma conta que, anteriormente as atuais normas de contabilidade, ficavam situada fora do patrimônio líquido, fica evidenciada a importância de se conhecer a composição do patrimônio líquido das empresas ao se extrair as informações necessárias para os mais diversos tipos de usuários.

O segundo setor com maior valor relativo de participação de não controladores foi o setor 1 de empresas relacionadas ao segmento agrícola e alimentício, que apresentou $8 \%$ de seu patrimônio líquido representado por essa conta. As empresas desse setor que mais contribuíram para essa representação foram:

Tabela 25- Participação de não controladores das empresas do setor 1: agrícola e alimentício

\begin{tabular}{|c|c|c|c|c|}
\hline Companhia & $\begin{array}{c}\text { Capital Social } \\
\text { R\$ mil }\end{array}$ & $\begin{array}{c}\text { Participação de } \\
\text { não controladores } \\
\text { R\$̣ mil }\end{array}$ & $\begin{array}{c}\text { Participação de } \\
\text { não controladores } \\
\text { \% do PL }\end{array}$ & $\begin{array}{c}\text { Total PL } \\
\text { R\$ mil }\end{array}$ \\
\hline CIA BEBIDAS DAS AMERICAS - AMBEV & 7.613 .780 & 202.979 & $1 \%$ & 24.564 .842 \\
\hline CIA BRASILEIRA DE DISTRIBUICAO & 5.579 .259 & 2.485 .181 & $26 \%$ & 9.583 .770 \\
\hline COSAN LIMITED & 5.328 & 2.767 .815 & $38 \%$ & 7.328 .697 \\
\hline COSTA PINTO S.A. & 66.824 & 221.492 & $40 \%$ & 551.170 \\
\hline JBS S.A. & 18.046.067 & 1.100 .478 & $6 \%$ & 18.694 .849 \\
\hline JOSAPAR-JOAQUIM OLIVEIRA S.A. - PARTICIP & 120.000 & 112.700 & $25 \%$ & 457.634 \\
\hline MARFRIG ALIMENTOS S/A & 4.061.478 & 143.125 & $2 \%$ & 6.496 .413 \\
\hline MINERVA S.A. & 251.642 & 33.779 & $6 \%$ & 540.273 \\
\hline Total das oito empresas & 35.744 .378 & $7.067 .549^{\circ}$ & $10 \%$ & 68.217.648 \\
\hline Total do setor 1 & 56.347 .629 & 7.073.282 & $8 \%$ & 90.207 .142 \\
\hline
\end{tabular}

O setor 1 é composto por 29 companhias do segmento agrícola e alimentício, e oito delas foram apresentadas na tabela acima. Essas companhias respondem por pouco mais de $99 \%$ do valor de participação de não controladores do grupo como um todo, e é possível notar que essas companhias exibem um valor relativo inferior àquelas que mais influenciaram o setor 2 de indústrias em geral, constantes na Tabela 24. Ainda que relativamente esse setor tenha apresentado uma participação menor de participação de não controladores do que o setor apresentado anteriormente, há companhias que apresentaram participação relativa dessa conta significativa dentro do patrimônio líquido, uma vez que em quatro delas mais de um quarto de seus PLs estava relacionado a essa conta. 
O terceiro setor com maior valor relativo de participação de não controladores foi o setor 4 composto por concessionárias de serviços públicos, que apresentou $7 \%$ de seu patrimônio líquido representado por essa conta. As empresas desse setor que mais contribuíram para essa representação foram:

Tabela 26- Participação de não controladores das empresas do setor 4: concessionárias de serviços

\begin{tabular}{|c|c|c|c|c|}
\hline Companhia & $\begin{array}{c}\text { Capital Social } \\
\text { R\$ mil }\end{array}$ & $\begin{array}{c}\text { Participação de } \\
\text { não controladores } \\
\text { R\$ mil }\end{array}$ & $\begin{array}{c}\text { Participação de } \\
\text { não controladores } \\
\text { \% do PL }\end{array}$ & $\begin{array}{c}\text { Total PL } \\
\mathrm{R} \$ \mathrm{mil}\end{array}$ \\
\hline CENTRAIS ELET BRAS S.A. - ELETROBRAS & 26.156 .567 & 226.296 & $0 \%$ & 70.530 .410 \\
\hline CIA BRASILIANA DE ENERGIA & 2.960 .709 & 3.263.227 & $44 \%$ & 7.435.024 \\
\hline CIA ENERGETICA DE BRASILIA & 342.056 & 224.306 & $31 \%$ & 714.306 \\
\hline COARI PARTICIPAÇÕES S.A. & 12.334 .064 & 6.105 .720 & $27 \%$ & 22.665 .518 \\
\hline CIA PARANAENSE DE ENERGIA - COPEL & 6.910 .000 & 265.703 & $2 \%$ & 11.295 .826 \\
\hline CPFL ENERGIA S.A. & 4.793.424 & 255.948 & $4 \%$ & 6.749 .656 \\
\hline CPFL GERACAO DE ENERGIA S.A. & 1.039 .618 & 179.521 & $9 \%$ & 2.088.394 \\
\hline EDP - ENERGIAS DO BRASILS.A. & 3.182.716 & 1.900 .643 & $29 \%$ & 6.455 .122 \\
\hline EMBRATEL PARTICIPACOES S.A. & 6.018 .064 & 241.278 & $2 \%$ & 10.690 .708 \\
\hline FORPART S.A. & 8.579 & 25.345 & $64 \%$ & 39.686 \\
\hline JEREISSATI PARTICIPACOES S.A. & 784.004 & 4.261 .880 & $80 \%$ & 5.344 .135 \\
\hline NEOENERGIA S.A. & 4.739 .025 & 848.639 & $8 \%$ & 11.256 .488 \\
\hline REDE ENERGIA S.A. & 714.552 & 1.336 .385 & $50 \%$ & 2.649 .565 \\
\hline Total das treze empresas & 69.983.378 & 19.134.891 & $12 \%$ & 157.914.838 \\
\hline Total do setor 4 & 148.093 .045 & 19.340.255 & $7 \%$ & 292.297.684 \\
\hline
\end{tabular}

A Tabela 26 demonstra que treze empresas apresentam quase que a totalidade do valor de participação de não controladores do grupo inteiro, apesar de representarem pouco mais de $47 \%$ do capital desse setor que é composto por 71 companhias. Assim como exposto na Tabela 24 relacionada a companhias industriais em geral do setor 2, as empresas que tiveram valores relativos mais altos respondem pela maior parte dos valores de participação de não controladores do grupo. Dessa forma, a concentração experimentada no setor 4 de empresas concessionárias de serviços públicos relacionada a esse quesito também esteve presente no setor 1 de empresas do segmento agrícola e alimentício, porém em menor intensidade.

A informação sobre valor de participação de acionistas não controladores não é apresentada em demonstrações contábeis de todas as empresas. Trata-se de um valor que era evidenciado em local diverso do que é atualmente. Portanto, caso os usuários das informações contábeis utilizassem essa informação já reclassificada, como sendo de fato componente do patrimônio líquido das companhias, essa nova localização pode não ter tido efeitos práticos.

No entanto, a alteração da forma de apresentação dessa conta pode ter impactos relevantes na apresentação das demonstrações contábeis. Como demonstrado acima, há casos em que parte 
considerável do patrimônio líquido é representada por participação de acionistas não controladores, eventualmente chegando a mais da metade desse grupo, e em companhias com valores altos envolvidos. Trata-se de uma questão importante para os usuários das informações contábeis, para que não percebam essa alteração de forma de evidenciação como sendo alterações na estrutura de endividamento das companhias, evitando, assim, que sejam conduzidos a caminhos equivocados. 


\section{ELABORAÇÃO DA PESQUISA}

\subsection{Questionários aplicados a professores de contabilidade}

Para que o objetivo do presente estudo seja alcançado, é necessário que de alguma maneira seja verificada a percepção dos usuários das informações contábeis acerca do tema explorado.

A percepção dos respondentes foi captada por meio da aplicação de questionários que são instrumentos importantes e populares de coleta de dados para uma pesquisa social, e são apresentados em forma de um conjunto ordenado e consistente de perguntas a respeito de variáveis e situações que se deseja medir ou descrever (MARTINS; TEÓPHILO, 2009).

Ao proceder à coleta de informações, podem ser verificados pelo pesquisador dois tipos de variáveis: quantitativas e qualitativas. As quantitativas são aquelas que envolvem caráter numérico, enquanto as qualitativas apresentam dificuldade maior de mensuração, por não envolverem fatores numéricos, contendo, assim, certo grau de subjetividade. As variáveis qualitativas, quando necessário, podem ser trabalhadas para apresentar uma série quantitativa. Essa adaptação é possível com a utilização de escalas sociais e de atitude (MARTINS; TEÓPHILO, 2009).

O questionário utilizado no presente estudo apresenta uma escala para medir atitudes, que podem ser definidas como "predisposição apreendida pelo sujeito para responder consistentemente, de maneira favorável ou desfavorável, a respeito de um objeto ou representação simbólica.” (MARTINS; TEÓPHILO, 2009, p.96). A escala escolhida foi a tipo Likert, desenvolvida por Rensis Likert no início dos anos 30 do século passado.

Questionários apresentam algumas vantagens que são:

a) possibilita atingir grande número de pessoas, mesmo que estejam dispersas numa área geográfica muito extensa, já que o questionário pode ser enviado pelo correio;

b) implica menores gastos com pessoal, posto que o questionário não exige o treinamento dos pesquisadores;

c) garante o anonimato das respostas;

d) permite que as pessoas o respondam no momento em que julgarem mais conveniente;

e) não expõe os pesquisados à influência das opiniões e do aspecto pessoal do entrevistado. (GIL, 1999, p.128-129). 
Os questionários, utilizados como técnica de pesquisa, apresentam também algumas limitações:
a) exclui as pessoas que não sabem ler e escrever, o que, em certas circunstâncias, conduz a graves deformações nos resultados da investigação;
b) impede o auxílio ao informante quando este não entende corretamente as instruções das perguntas;
c) impede o conhecimento das circunstâncias em que foi respondido, o que pode ser importante na avaliação da qualidade das respostas;
d) não oferece garantia de que a maioria das pessoas devolvam-no devidamente preenchido, o que pode implicar a significativa diminuição da representatividade da amostra;
e) envolve, geralmente, número relativamente pequeno de perguntas, porque é sabido que questionários muito extensos apresentam alta probabilidade de não serem respondidos;
f) proporciona resultados bastante críticos em relação à objetividade, pois os itens podem ter significado diferente para cada sujeito pesquisado. (GIL, 1999, p.129).

No questionário utilizado apresentou-se uma escala que variou de um a nove, sendo que o número um representou grau máximo de discordância com as afirmações propostas, enquanto o nove representou grau máximo de concordância com as afirmações propostas. Os números intermediários significaram níveis de concordância/discordância parciais situados entre os extremos.

Grande parte das variáveis em pesquisas sociais não são mensuradas numericamente, mas é possível colocá-las em categorias. A observação dos elementos da amostra resulta em dados categorizados. As variáveis devem ser bem definidas, de maneira que cada elemento pesquisado se encaixe em apenas uma categoria (BARBETTA, 2007).

A aplicação dos questionários foi feita a um grupo específico de usuários da informação contábil, os professores de contabilidade. As respostas obtidas que não se referiam a esse grupo de respondentes foram descartadas.

O modelo do questionário aplicado encontra-se na seção de apêndice do presente estudo.

Inicialmente, o presente estudo tinha um enfoque diferente do que acabou sendo utilizado em sua modalidade final. $\mathrm{O}$ questionário era composto por um número maior de perguntas, e o público-alvo não estava restrito a professores de contabilidade, mas aberto a todos os usuários da contabilidade.

Sabe-se que há um grande número de modalidades de usuários da contabilidade, que podem ser desde experts no assunto, como usuários sem conhecimento técnico aprofundado. Sendo 
assim, reunir as respostas de uma mesma maneira, para produzir uma informação posterior, não pareceu adequado. Restringiu-se, então, a aplicação do questionário a um grupo de usuários específico. Inicialmente, optou-se por pesquisar a percepção de analistas de mercado pela ligação que possuem com as informações contábeis fornecidas pelas empresas. Tal escolha não se mostrou viável no decorrer do estudo devido à dificuldade na obtenção de respostas. Dessa maneira, partiu-se para outro grupo de usuários, o de professores de contabilidade. Comparativamente, o acesso aos professores para elaboração da pesquisa apresentou menos dificuldades do que o acesso ao grupo de usuários composto por analistas de mercado. Adicionalmente os professores de contabilidade são os responsáveis por colocar novos profissionais em contato com a contabilidade. Os professores fornecem embasamento teórico e prático para que esses novos profissionais possam desempenhar seu papel no cenário da contabilidade, esses novos profissionais que serão desde elaboradores de demonstrações contábeis até usuários diretos da contabilidade das mais diversas formas. Sendo assim, pela possibilidade de acesso a esses docentes para elaboração, e também pela familiaridade com a contabilidade que precisam possuir, esse grupo se apresentou adequado ao propósito do estudo.

\subsection{Condições de aplicação do questionário}

O questionário, em um primeiro momento, foi aplicado a um pequeno grupo de conhecedores de contabilidade, que na época estavam ao menos com os créditos do mestrado em contabilidade concluídos, a título de pré-teste. Com base no retorno promovido por esse grupo, foi possível chegar à versão final aplicada aos professores de contabilidade.

Não foram aplicadas restrições de natureza territorial para disponibilização do questionário. Para que pudesse chegar às instituições de ensino, consequentemente viabilizando o alcance do público-alvo, foi necessário obter um endereço de email ou algum dado de contato das instituições de ensino que oferecem o curso de bacharelado em Ciências Contábeis.

Como primeira opção foi contatado o Conselho Federal de Contabilidade - CFC, com a intenção de obter o endereço de email dos coordenadores de cursos de contabilidade no Brasil e a resposta obtida foi de que não tinham essa informação. 
Alternativamente, foi realizado contato com o Guia do Estudante, da Abril, para obter-se as mesmas informações previamente solicitadas ao CFC. O Guia do Estudante prontamente respondeu à solicitação, e na figura de seu diretor de redação autorizou a utilização dos endereços de email que tinham. Foi fornecido um arquivo com o mailing de 1.115 cursos de graduação no país, com informações baseadas na última atualização feita diretamente com as instituições, entre dezembro de 2011 e março de 2012.

Partiu-se, então, para a distribuição dos questionários, com a solicitação para que fossem enviados aos docentes dos cursos para participação na pesquisa. A distribuição foi feita por meio de mensagens eletrônicas (emails) contendo em seu corpo, além da descrição de características básicas do questionário, o link para o questionário hospedado no Google Docs. Foi, também, incluída uma versão do questionário no corpo do email para aqueles que preferissem responder sem acessar ao link. Foram 23 os respondentes que preferiram participar dessa forma.

Das mensagens enviadas em um primeiro momento, 118 voltaram por problemas no envio. Nesses casos, tentou-se obter endereço de email válido pelos sites institucionais das faculdades e universidades, assim como pelas páginas das instituições em um determinado site de relacionamento, o Facebook. Dessas duas formas de tentativa, as respostas foram mais rápidas e em maior número pelo site de relacionamento.

A distribuição dos questionários iniciou-se no dia 29 de novembro de 2012 e a primeira fase encerrou-se no dia 04 de dezembro de 2012. A segunda fase de distribuição dos questionários, que consistiu no seu envio às instituições cujas mensagens eletrônicas retornaram por algum problema de envio, finalizou em 18 de dezembro de 2012.

Foram recepcionadas respostas até o dia 22 de janeiro de 2013 e, a partir disso, iniciou-se o trabalho de tabulação dos dados coletados.

\subsection{Características do questionário aplicado}

O questionário aplicado foi composto por variáveis não métricas, que são aquelas "que se referem a atributos ou características categóricas, como indicadores de preferência, presença 
ou ausência de determinada propriedade, e podem ser subdivididas em escalas nominais e ordinais." (FÁVERO et al., 2009, p.7).

As variáveis não métricas são também conhecidas como variáveis qualitativas e têm dados em escala nominal ou ordinal, e não podem apresentar medidas de posição ou de dispersão, em função de suas escalas de mensuração. Com base nessas variáveis é possível a elaboração apenas de análises de frequência, como por exemplo o cálculo da moda. São exemplos de medidas de posição a média aritmética, a mediana, a moda, o percentil. São exemplos de medidas de dispersão o desvio- padrão, variância, intervalo interquartil e a amplitude (FÁVERO et al., 2009).

As variáveis qualitativas podem ser divididas em qualitativa nominal, para a qual não existe nenhuma ordenação nas possíveis realizações, e em qualitativa ordinal, para a qual existe uma ordem nos seus resultados (BUSSAB; MORETTIN, 2002).

As escalas ordinais, que são as aplicadas no presente questionário, admitem uma relação numérica das suas respostas alternativas, estabelecendo uma relação de ordem entre elas. Nesse caso, não é possível medir a magnitude das diferenças entre as categorias (HILL; HILL, 2008).

O questionário foi elaborado fazendo uso da escala tipo Likert, na qual houve o apontamento de uma escala de preferência. O uso da escala tipo Likert tem certa preferência por parte dos pesquisadores pela possibilidade de o questionário ser montado com várias perguntas em sequência, todas com as mesmas alternativas de respostas, propiciando ao respondente uma maior facilidade de interpretação e tornando menor o tempo total da entrevista (FÁVERO et al., 2009).

As escalas de preferência têm apenas um significado de classificação, e as estatísticas que podem ser calculadas a partir de dados ordinais são a moda e a distribuição de frequência (SHARMA, 1996; COOPER; SCHINDLER (2003 apud FÁVERO et al., 2009)).

Ao estudar uma variável, o maior interesse do pesquisador é conhecer o comportamento dessa variável, analisando a ocorrência de suas possíveis realizações. A tabela de frequências 
absolutas é uma maneira de dispor um conjunto de realizações, ou seja, sua distribuição. $\mathrm{Na}$ interpretação dos dados, uma medida bastante útil é a proporção de cada realização em relação ao total, também conhecida como frequência relativa. As proporções são muito úteis quando a intenção é de se comparar duas pesquisas distintas, nas quais totais podem ser diferentes, mas as porcentagens são comparáveis (BUSSAB; MORETTIN, 2002).

O resumo de dados por meio de tabelas de frequência fornecem muito mais informações sobre o comportamento de uma variável do que a própria tabela original de dados. É possível ter a intenção de se resumir ainda mais os dados, apresentando um ou alguns valores que possam representar toda a série. Usualmente são utilizadas medidas de posição como a média, mediana ou moda. No caso de se apresentar um só valor há uma redução drástica dos dados (BUSSAB; MORETTIN, 2002).

O gráfico de barras e o gráfico em forma de pizza são os gráficos mais comuns para a criação de dados oriundos de variáveis qualitativas, mostrando as frequências de observações para cada nível ou categoria da variável que se deseja descrever (MARTINS, 2008).

Seguindo-se nessa linha, com base nas respostas obtidas, foram apresentadas as distribuições de frequências absolutas por meio de gráficos de barra, as distribuições de frequências relativas por meio de gráficos de pizza, e a moda presente em cada resposta, sendo esta última uma medida de tendência central que resulta no valor mais frequente do conjunto de observações, e é a única das medidas de posição aplicável a variáveis não métricas.

\subsection{Confiabilidade do questionário aplicado}

Qualquer pesquisa baseada em mensuração deve se preocupar com precisão ou, então, confiabilidade das medidas. Um coeficiente de confiabilidade demonstra se aquele que elaborou os testes estava correto em esperar um certo conjunto de itens para permitir afirmações que possam ser interpretadas a respeito de diferenças individuais (CRONBACH, $1951) .^{2}$

\footnotetext{
${ }^{2}$ Tradução livre: "Any research based on measurement must be concerned with the accuracy or dependability or,
} as we usually call it, reliability of measurement. A reliability coefficient demonstrates whether the test 
Há métodos distintos para se estimar a confiabilidade de questionários: estabilidade temporal, versões equivalentes, consistência interna do tipo split-half, e o coeficiente alfa $(\alpha)$ desenvolvido pelo investigador americano Cronbach, sendo este considerado "um método melhor para se estimar a consistência interna (fiabilidade interna) de um questionário" (HILL; HILL, 2008, p.146). A técnica desenvolvida por Cronbach estima o coeficiente da confiabilidade interna como o valor médio de todos os coeficientes possíveis do tipo splithalf.(HILL; HILL, 2008).

O valor de $\alpha$ pode ser estimado com o uso da seguinte fórmula (HILL; HILL, 2008, p.147):

$$
\alpha=\frac{k}{k-1}\left(1-\frac{\text { Soma das variâncias de cada item }}{\text { Variância total dos } k \text { itens }}\right)
$$

em que: $\mathrm{k}$ = número de itens no questionário.

Alternativamente o valor de $\alpha$ também pode ser estimado utilizando-se a seguinte fórmula ((MARTINS; TEÓPHILO, 2009, p.15):

$$
\alpha=\frac{N \bar{\rho}}{[1+\bar{\rho}(N-1)]}
$$

em que:

$\mathrm{N}=$ número de itens;

$\bar{\rho}=$ média dos coeficientes de correlação linear (Pearson) entre os itens.

Com a intenção de testar a confiabilidade das medidas, foi aplicado o coeficiente alfa de Cronbach, que "foi desenvolvido por J.L. Cronbach, e o seu cálculo $(\alpha)$, alfa, carece de uma única aplicação do instrumento de medição, produzindo valores entre 0 e 1 , ou entre 0 e $100 \%$. Quando o coeficiente for superior a $70 \%$ diz-se que há confiabilidade das medidas.” 
(MARTINS; TEÓPHILO, 2009, p.15).Hair et al (2005) afirmam ser aceitável o coeficiente em 0,60 quando se trata de pesquisa exploratória. Hill e Hill (2008) atestam que o coeficiente acima de 0,9 como excelente, entre 0,8 e 0,9 como bom, entre 0,7 e 0,8 como razoável, entre 0,6 e 0,7 como fraco, apresentando como inaceitável valor abaixo de 0,6.

Essa forma de certificar a confiabilidade das medidas é obtida pelo cálculo das correlações entre o escore de cada item e o total dos demais itens. $\mathrm{O}$ valor do coeficiente é a média de todos os coeficientes de correlação. "As correlações item-total e o valor de alfa de Cronbach são reveladoras porque fornecem informações sobre cada item individual. Itens que não estão correlacionados com os demais podem ser eliminados para aumentar a confiabilidade." (MARTINS, 2006, p. 5).

Com a utilização do software estatístico IBM SPSS Statistics foram encontrados os valores constantes nas Ilustrações 2 e 3 :

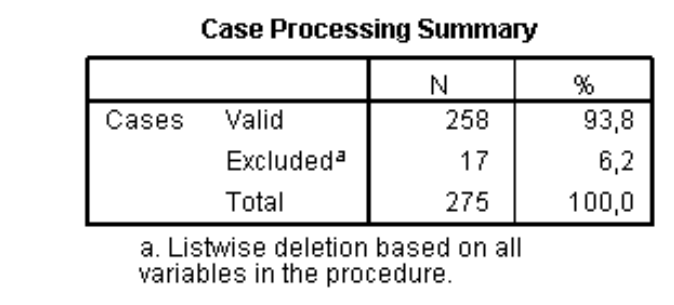

Ilustração 2 - Resumo dos itens processados

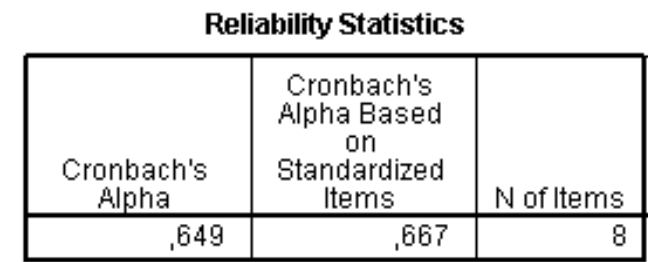

Ilustração 3 - Resultado do Alfa de Cronbach

O coeficiente com base nos questionários respondidos ficou em 0,649, acima do que seria aceitável em casos de pesquisas exploratórias, caracterizando a confiabilidade das respostas como fraca.

\subsection{Respostas do questionário aplicado}

Os questionários foram direcionados a 1.115 instituições de ensino de nível superior no Brasil que oferecem cursos de bacharelado em Ciências Contábeis. O texto que apresentou o 
questionário solicitava o seu encaminhamento a professores de contabilidade que lecionavam nesses cursos.

Foram respondidos 276 questionários, porém três deles caracterizaram o respondente como não sendo professor de contabilidade, o que resultou na exclusão desses três do trabalho final.

As questões presentes no questionário têm relação com os valores identificados no capítulo anterior, que identifica valores do patrimônio líquido de empresas de capital aberto no ano de 2010. A relação estabelecida é apresentada no Quadro 3:

Quadro 3 - Relação entre perguntas do questionário e levantamento de dados de companhias abertas

\begin{tabular}{|c|c|}
\hline Perguntas do questionário & Itens identificados \\
\hline $\begin{array}{l}\text { O valor do Patrimônio Líquido }(P L) \text { de uma empresa é informação } \\
\text { importante para os usuários da contabilidade. }\end{array}$ & \\
\hline $\begin{array}{l}\text { 2. A composição do PL é informação importante para os usuários da } \\
\text { informação contábil. }\end{array}$ & 3.2 Patrimônio líquido das empresas selecionadas \\
\hline $\begin{array}{l}\text { As alterações provocadas no PL das empresas pelos pronunciamentos } \\
\text { 3. do CPC - Comitê de Pronunciamentos Contábeis afetaram } \\
\text { significativamente o valor total desse grupo. }\end{array}$ & \\
\hline $\begin{array}{l}\text { As alterações provocadas no PL das empresas pelos pronunciamentos } \\
\text { do CPC afetaram de forma homogênea empresas de setores distintos. }\end{array}$ & \\
\hline $\begin{array}{l}\text { As alterações provocadas no PL das empresas pelos pronunciamentos } \\
\text { do CPC dificultaram a comparabilidade entre demonstrações contábeis } \\
\text { da própria empresa elaboradas antes e após tais alterações. }\end{array}$ & 3.3 Patrimônio líquido das empresas selecionadas por setor \\
\hline $\begin{array}{l}\text { As alterações introduzidas no PL pelos pronunciamentos do CPC } \\
\text { 6. dificultaram a comparabilidade entre demonstrações contábeis de } \\
\text { empresas pertencentes a segmentos distintos. }\end{array}$ & \\
\hline $\begin{array}{l}\text { Conhecer a composição do PL e não somente seu valor total se tornou } \\
\text { 7. mais importante após as alterações introduzidas pelos pronunciamentos } \\
\text { do CPC. }\end{array}$ & $\begin{array}{l}\text { 3.4 Composição do patrimônio líquido das empresas } \\
\text { selecionadas por setor }\end{array}$ \\
\hline $\begin{array}{l}\text { Considero importante transmitir aos alunos conhecimentos relacionados } \\
\text { 8. composição do } \mathrm{PL} \text { e como tal composição pode afetar a utilização das } \\
\text { informações contábeis. }\end{array}$ & \\
\hline
\end{tabular}

Essa relação entre perguntas e os dados levantados de companhias abertas foi delineada considerando-se itens que têm maior similaridade entre si, não significando que os valores identificados em determinado item do trabalho possam se relacionar exclusivamente com uma determinada questão.

Dos 273 questionários respondidos, 218 respondentes demonstraram interesse em receber cópia dos resultados obtidos. Essa totalidade dos questionários compreendeu respostas de 20 unidades da federação e, dentro dessa totalidade, 15 respondentes preferiram não informar esse dado. 
A distribuição das respostas por unidades da federação é apresentada no gráfico a seguir:

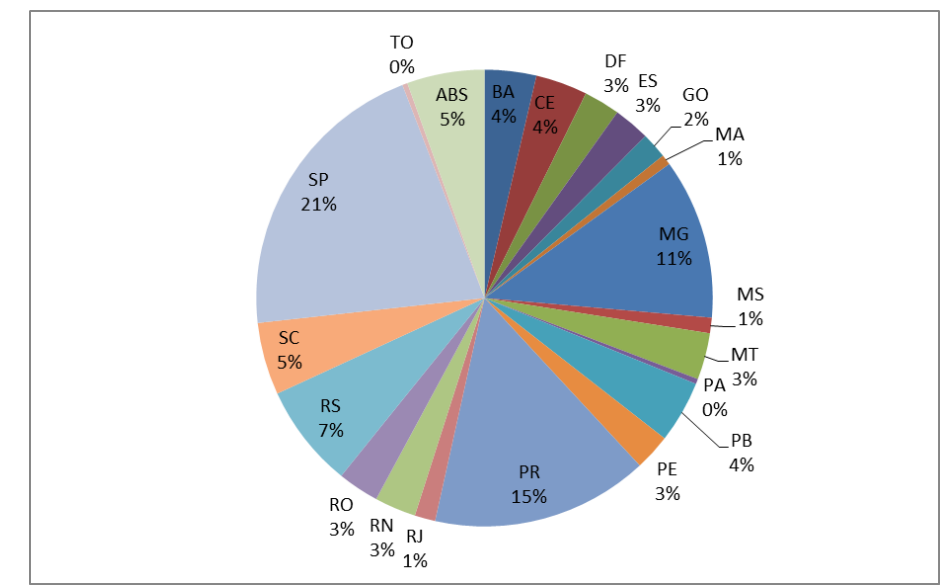

Gráfico 1 - Distribuição relativa de respostas por unidade da federação

A unidade da federação da qual vieram mais respostas foi São Paulo com 57, seguida por Paraná com 42 e Minas Gerais com 31.

\subsubsection{Questão 1 - O valor do Patrimônio Líquido (PL) de uma empresa é informação importante para os usuários da contabilidade}

O valor do patrimônio líquido é um valor residual entre ativos e passivos, sendo, dessa maneira, um componente fundamental na estrutura patrimonial das empresas. Pelo papel que desempenha nessa estrutura seria de se esperar que as respostas apontassem um alto grau de concordância com essa afirmação, e foi o que aconteceu.

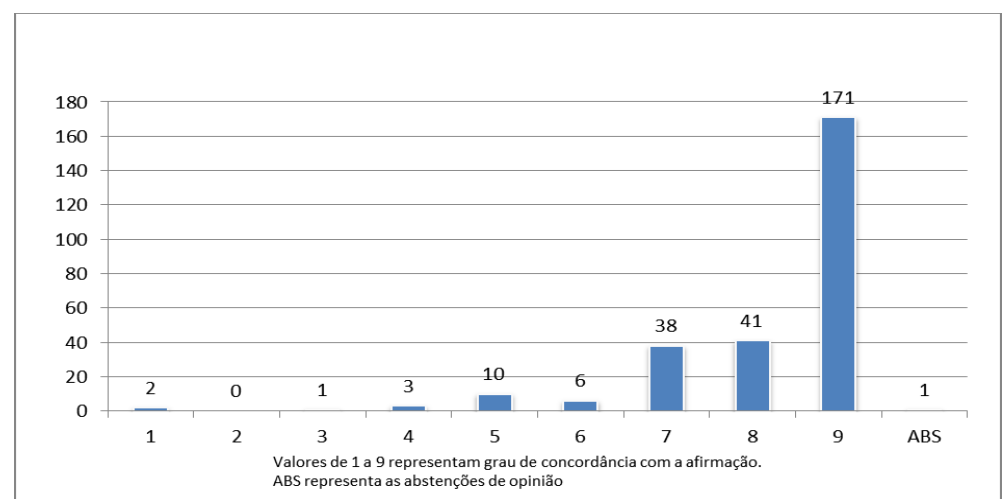

Gráfico 2 - Importância do PL para os usuários da contabilidade

A resposta mais presente foi a que indica grau máximo de concordância com a afirmação, e os três níveis de maior concordância com a afirmação foram responsáveis por mais de $91 \%$ das respostas, sendo que apenas duas respostas discordaram completamente de que o valor do PL é uma informação importante para os usuários da contabilidade. 


\subsubsection{Questão 2 - A composição do PL é informação importante para os usuários da informação contábil}

A forma como o patrimônio líquido é composto pode também interessar aos usuários da informação contábil, pois há partes que têm natureza distinta, como é o caso do capital social, praticamente a parte mais consistente do patrimônio líquido, e a conta de dividendos adicionais propostos, decorrente de uma classificação temporária, tendo sua transferência esperada para o passivo em um curto prazo.

Assim como ocorrido com a questão anterior, também é esperado que uma grande proporção de respostas apresente concordância com essa afirmação.

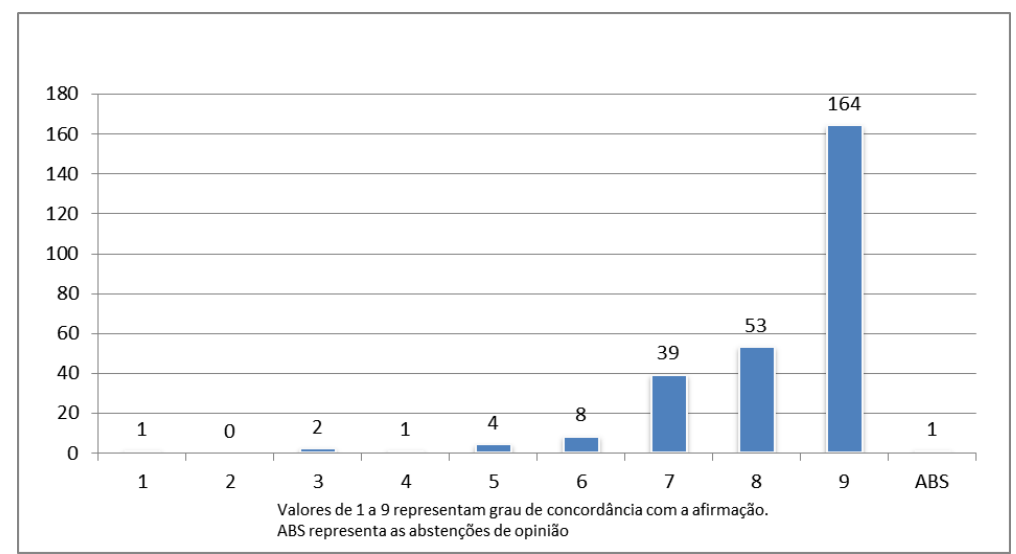

Gráfico 3 - Importância da composição do PL para os usuários da contabilidade

A resposta mais presente foi a concordância completa com a afirmação, e sozinha representou pouco mais de $60 \%$ das respostas. As três respostas que indicaram o nível mais alto de concordância foram responsáveis por $93,7 \%$ do total e, apenas, três respostas indicaram algum grau de discordância.

Com base nas questões 1 e 2 é possível afirmar que os usuários da contabilidade reconhecem a importância tanto do valor total, como da composição do patrimônio líquido das empresas.

\subsubsection{Questão 3 - As alterações provocadas no PL das empresas pelos pronunciamentos do CPC - Comitê de Pronunciamentos Contábeis afetaram significativamente o valor total desse grupo}

A forma como as alterações contábeis promovidas pelo CPC foram percebidas pelos usuários da contabilidade pode se apresentar de maneira diferente entre eles. Essa questão teve por objetivo verificar se essas alterações foram percebidas igualmente entre tais usuários ou não. 
Nessa questão, o grau de concordância com a afirmação já não foi tão homogêneo como havia sido nas questões 1 e 2 .

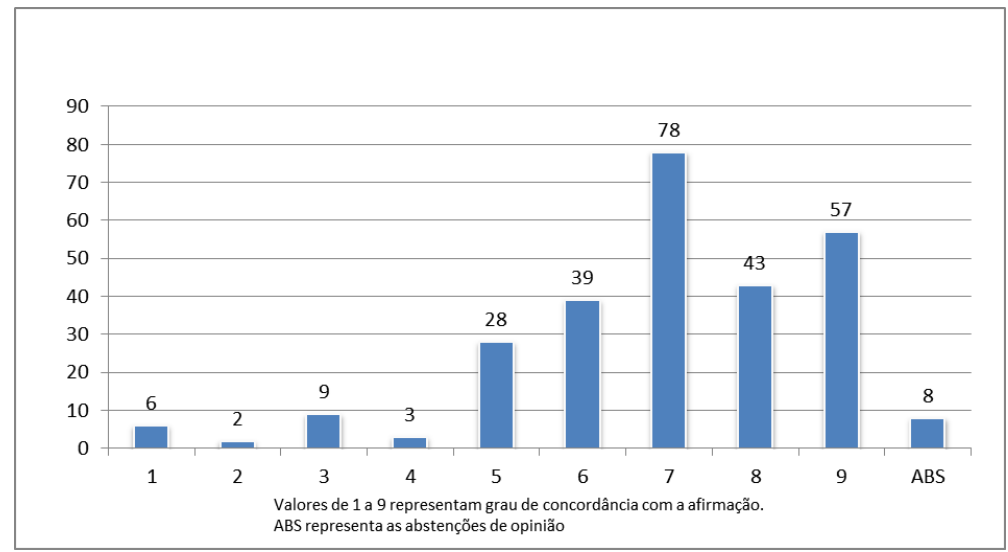

Gráfico 4 - Impacto significativo no PL das empresas pelos pronunciamentos do CPC

A maior parte dos respondentes consentiu, em algum grau, com a afirmação apresentada, mas de maneira diversa do apresentado nas duas questões anteriores. O maior número de respostas não ficou com o grau máximo de concordância representado pelo número nove, mas com um grau de número 7 o que representa uma concordância intermediária.

Dos respondentes, 79,4\% apresentou algum grau de concordância, o que foi representado pelos números 6 a 9. Com relação às duas primeiras questões, essa questão já não pode ser considerada como uma questão na qual as respostas são homogêneas, e o grau de concordância com maior número de respostas concentrou $28,5 \%$ delas.

O fato do número de respostas denotando não concordar com a afirmativa ter aumentado mostra também uma dispersão um pouco maior nas respostas, totalizando 7,3\%. Para esses respondentes, as alterações promovidas pelo CPC não tiveram impacto significativo ou, até mesmo, não tiveram impacto no patrimônio líquido das empresas.

Do total de respondentes, oito preferiram não opinar, o que representa o maior número de abstenção em repostas presente no questionário. 


\subsubsection{Questão 4 - As alterações provocadas no PL das empresas pelos pronunciamentos do CPC afetaram de forma homogênea empresas de setores distintos}

A presente questão teve por objetivo captar a percepção dos participantes da pesquisa a respeito da forma com que as alterações contábeis promovidas pelo CPC afetaram empresas de setores distintos. Essa percepção, para boa parte de possíveis modalidades de participantes, poderia ter sido muito particular, pois cada usuário específico da contabilidade está inserido em um ambiente e se relaciona com um ou poucos determinados segmentos. Essa particularidade levaria a uma dispersão nas respostas.

É possível que para o público específico dessa pesquisa, professores de contabilidade, essa dispersão não fosse presente, por não estarem restritos a um ou poucos segmentos de empresas, porque pela natureza da função que exercem permanecem em contato constantemente com informações contábeis de diversos segmentos da economia.

No entanto, o esperado não se realizou. Esse grupo não apresentou homogeneidade nas respostas. O maior número de respostas foi encontrado em um valor da escala que representa concordância relativa com a afirmativa presente na questão, o número 7, com 47 respostas. Com apenas uma resposta a menos, 46 respondentes indicaram o número 5, representando indefinição, não concordando e também não discordando.

Adicionalmente é válido frisar que 129 respostas apontaram algum grau de concordância acima do número 5 já comentado anteriormente, e 94 respostas apontaram algum grau de concordância abaixo da escala intermediária do número 5, significando, assim, discordância. Quatro participantes abstiveram-se de opinar nessa questão.

Segue distribuição das respostas no Gráfico 5: 


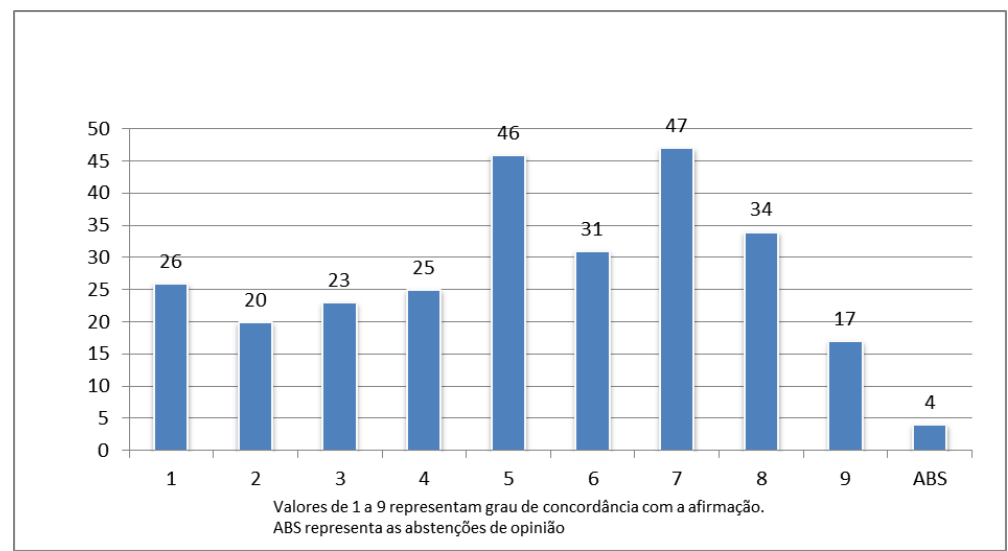

Gráfico 5- Empresas de setores distintos tiveram seus PLs foram afetados de forma homogênea pelos pronunciamentos do CPC

A dispersão apresentada pelas respostas aponta para uma falta de consenso entre os professores de contabilidade sobre a forma como empresas de setores distintos tiveram seus PLs impactados nas mudanças contábeis introduzidas pelo CPC.

\subsubsection{Questão 5 - As alterações provocadas no PL das empresas pelos pronunciamentos do $\mathrm{CPC}$ dificultaram a comparabilidade entre demonstrações contábeis da própria empresa elaboradas antes e após tais alterações}

As respostas a essa questão apresentaram a percepção dos participantes sobre a comparação de demonstrações contábeis de uma mesma empresa elaboradas antes e após as alterações no PL introduzidas pelo CPC. Esperou-se que essas respostas poderiam de alguma forma seguir as respostas apresentadas na questão de número três que apresentou um alto grau de concordância com a afirmação de que o valor total do PL foi afetado significativamente pelas já citadas alterações. Se as alterações foram significativas, compreensível que, quanto maior o impacto promovido por elas, maior a dificuldade de comparação entre os períodos anteriores e posteriores a elas.

As respostas da questão de número três apresentaram uma concentração das respostas no sentido de concordar com a afirmação apresentada. Na questão atual, houve uma tendência um pouco maior em discordar da afirmativa, fazendo com que as respostas ficassem menos concentradas, ainda que a maior parte delas apresentasse algum grau de concordância.

O maior número de respostas foi encontrado exatamente no número 7 , com 44 respostas, apresentado um relativo grau de concordância. 
Das respostas apresentadas, 77 apontaram algum grau de discordância, indicando os números de um a quatro, enquanto 157 apresentaram algum grau de concordância, indicando os números de 6 a 9. Houve, dessa maneira, uma preferência por concordar com a afirmação, embora 36 participantes tenham indicado o número 5, intermediário da escala, e 3 abstiveramse de responder.

Segue distribuição das respostas no Gráfico 6:

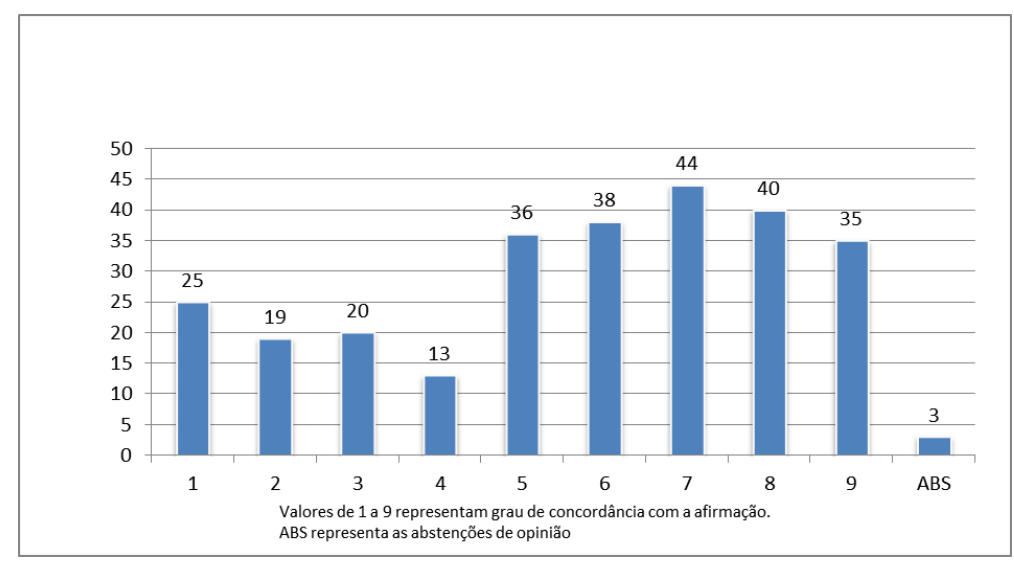

Gráfico 6 - Alterações promovidas pelo CPC dificultaram comparabilidade entre demonstrações contábeis da própria empresa elaboradas em períodos distintos

A dispersão apresentada pelas respostas aponta para uma falta de consenso entre os professores de contabilidade sobre a dificuldade de se comparar demonstrações contábeis de uma mesma empresa antes e após as alterações do PL promovidas pelo CPC, embora tenha havido uma maior concentração em respostas que denotaram de alguma maneira a concordância com a afirmação.

\subsubsection{Questão 6 - As alterações introduzidas no PL pelos pronunciamentos do CPC dificultaram a comparabilidade entre demonstrações contábeis de empresas pertencentes a segmentos distintos}

Assim como na questão de número quatro, essa questão aborda a maneira como as alterações introduzidas pelo CPC podem ter afetado o PL de empresas pertencentes a segmentos distintos. Portanto, seria de se esperar que as respostas apontassem aproximadamente para a mesma direção, e foi o que aconteceu.

Exatamente como o que aconteceu com as respostas à questão de número quatro, um número significativo de respostas apresentou grau intermediário de concordância, o número 5, com 45 respostas. Contudo, nesta questão, esse grau intermediário de concordância representou a 
maior concentração de respostas. Abaixo desse grau intermediário foram 97 respostas, acima foram 129 respostas, enquanto 2 participantes preferiram abster-se da resposta.

Essas duas questões, a quatro e a seis, tiveram o maior número de respostas relacionadas a um grau de concordância intermediário, e apesar de apresentar um número de respostas que representaram algum grau de concordância superior ao número de respostas que apresentaram algum grau de discordância com a afirmação, essa diferença não pode significar que há algum consenso na resposta.

Segue distribuição das respostas no Gráfico 7:

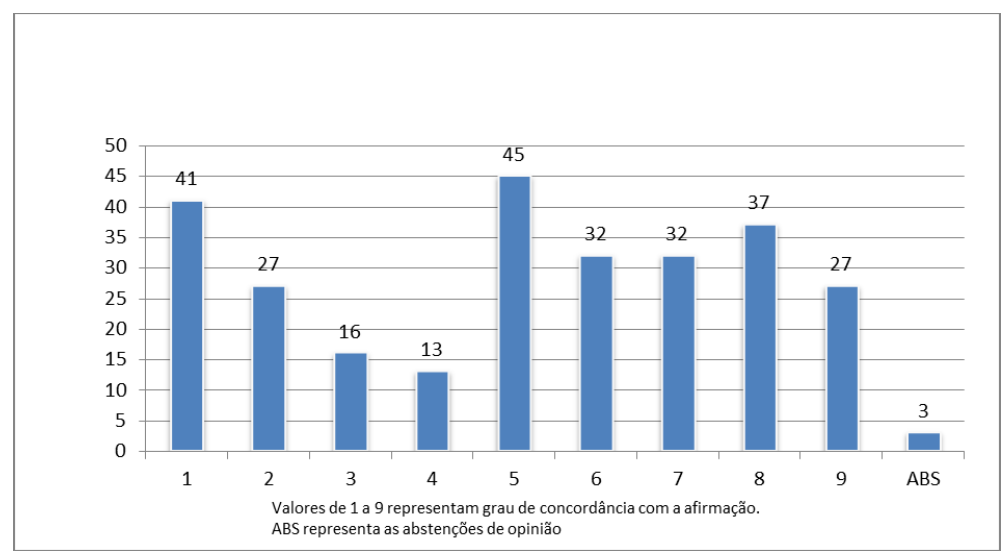

Gráfico 7 - Alterações promovidas pelo CPC dificultaram comparabilidade entre demonstrações contábeis de empresas pertencentes a segmentos distintos

A falta de homogeneidade apresentada pelas respostas das questões de números quatro e seis denota não haver harmonia por parte dos respondentes quando se trata do impacto das alterações em segmentos distintos.

\subsubsection{Questão 7 - Conhecer a composição do PL e não somente seu valor total se tornou mais importante após as alterações introduzidas pelos pronunciamentos do CPC}

As alterações promovidas no PL das empresas pelo CPC fizeram com que novos itens passassem a figurar nesse grupo e, também, valores que anteriormente estavam classificados de forma diferente passassem a integrar esse grupo.

A afirmativa que foi apresentada, na questão sete, pretendeu captar a percepção dos respondentes sobre a importância de se conhecer a composição do patrimônio líquido das empresas, e não somente seu valor total. 
O maior número de respostas apresentou grau máximo de concordância com a afirmação proposta. Foram 104 respostas. Do total de respostas, 217 apresentaram algum grau de concordância, 24 indicaram um grau intermediário de concordância e 30 indicaram algum grau de discordância. Do total de participantes, 2 preferiram abster-se de responder a essa questão.

Segue distribuição das respostas no Gráfico 8:

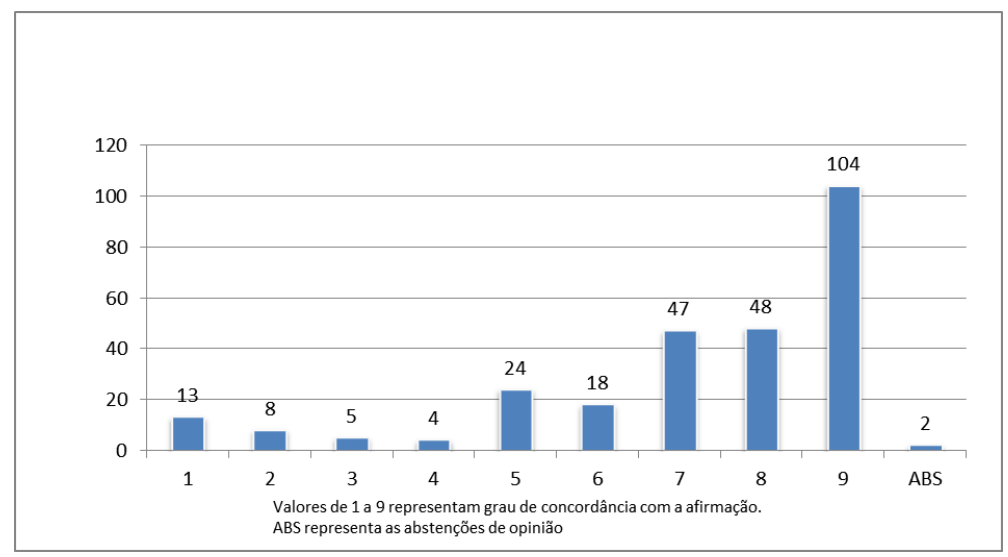

Gráfico 8 - Conhecimento da composição do PL se tornou mais importante após os pronunciamentos do CPC

Nessa questão é apresentado consenso sobre ter se tornado mais importante conhecer a composição do PL após as alterações introduzidas pelo $\mathrm{CPC}$, demonstrando que os participantes da pesquisa reconhecem a diversidade da natureza das contas contidas nesse grupo.

\subsubsection{Questão 8 - Considero importante transmitir aos alunos conhecimentos relacionados à composição do $\mathrm{PL}$ e como tal composição pode afetar a utilização das informações contábeis}

A presente questão teve a pretensão de identificar a importância por parte dos docentes da área contábil em transmitir aos seus alunos conhecimentos sobre a composição do patrimônio líquido das empresas.

Ao reconhecer a importância dessa composição, considera-se que as partes do patrimônio líquido de uma empresa não são todas iguais, pois se fossem não haveria necessidade de conhecer a composição desse grupo, mas apenas seu total. 
O mais alto grau de concordância com a afirmação foi a resposta mais apontada, tendo sido assinalada 197 vezes. Esse fato torna essa questão a que apresentou maior número de respostas em uma alternativa.

Apresentaram algum grau de concordância com a afirmação 262 respostas, quase $96 \%$ do total e, apenas 5 respostas apresentaram algum grau de discordância. Outras 5 respostas apontaram um grau intermediário de concordância e 1 participante preferiu abster-se de opinião.

Segue distribuição das respostas no Gráfico 9:

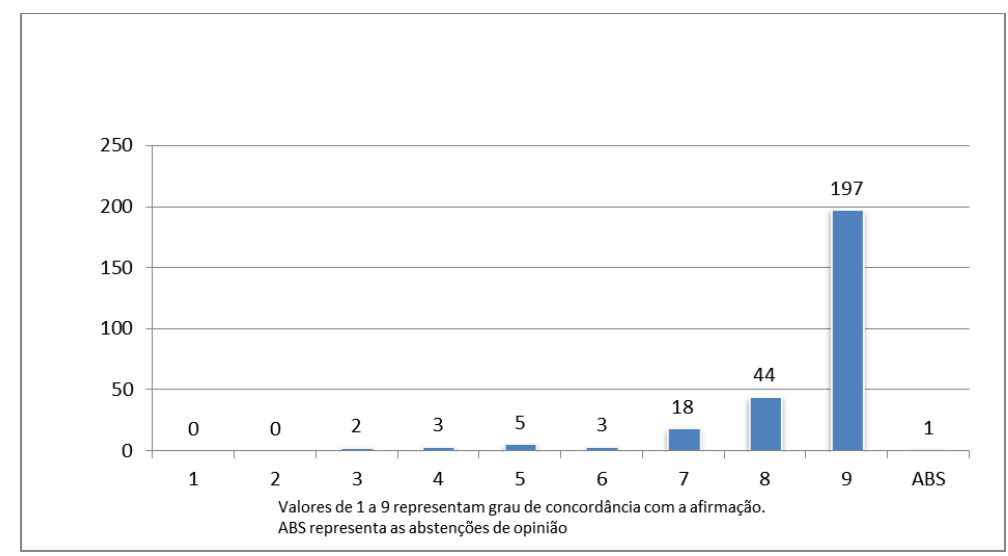

Gráfico 9 - Importância da transmissão aos alunos de conhecimentos relacionados à composição do PL e de como pode afetar a utilização das informações contábeis

Sendo a questão que apresentou maior grau de consenso entre todas, é possível interpretar, com base nas respostas apresentadas, que conhecer o valor total do patrimônio líquido das empresas não é considerado pelos respondentes como suficiente para utilizar as informações contábeis, sendo necessário conhecer a composição desse grupo.

Dentro do patrimônio líquido de uma empresa podem existir contas de diversas naturezas. Um patrimônio líquido composto totalmente por capital social e reservas não pode ser considerado igual a um patrimônio líquido em que há contas como dividendos adicionais propostos, participação de não controladores e ajustes de avaliação patrimonial, por exemplo. O primeiro apresenta um caráter mais permanente e estável do que o segundo, no qual se espera que os dividendos adicionais propostos sejam transferidos para o passivo em um curto prazo, a participação de não controladores até pouco tempo atrás nem figurava no patrimônio líquido, e o ajuste de avaliação patrimonial pode nunca vir a se transformar em resultado do exercício, consequentemente pode nunca vir a compor o patrimônio líquido de forma mais estável. 


\subsection{Correspondência entre dados levantados a partir de balanços publicados e percepção dos professores de contabilidade}

Os dados das companhias abertas obtidos no capítulo três e as respostas apresentadas neste capítulo, até o momento, têm vinculação. No capítulo três foram levantados valores extraídos de demonstrações contábeis enquanto no questionário apresentado neste capítulo foram mostradas as percepções de professores de contabilidade sobre o mesmo assunto.

Elaborou-se um quadro com a intenção de relacionar essas duas partes de forma mais objetiva.

Quadro 4 - Relação entre dados levantados e percepção dos professores de contabilidade

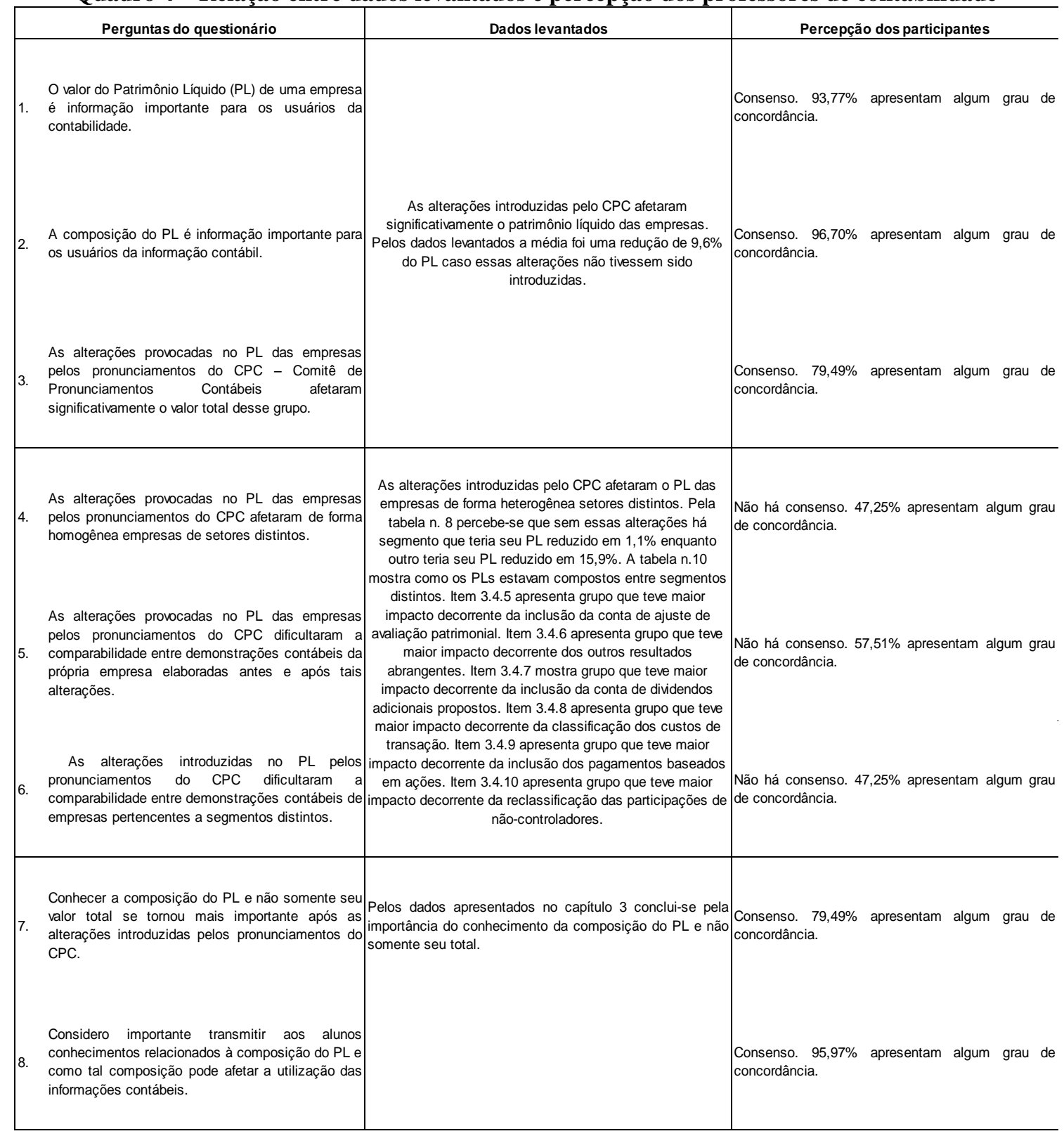


É possível notar que as perguntas do questionário e os dados levantados a partir de demonstrações contábeis de companhias abertas podem ser divididos em três grupos:

- o primeiro que abordou a questão da importância do PL para os usuários da contabilidade e o impacto das alterações introduzidas pelo CPC no valor total desse grupo;

- o segundo que abordou a questão do impacto das alterações introduzidas pelo CPC na composição do PL de empresas de setores distintos e das próprias empresas em períodos pré e pós adoção dessas alterações;

- o terceiro que abordou a questão da importância de se conhecer a composição do PL após as alterações introduzidas pelo CPC, assim como de se transmitir esse conhecimento aos alunos dos cursos de contabilidade.

Com relação ao primeiro grupo os dados levantados e a percepção dos professores de contabilidade apontaram que o valor e a composição do patrimônio líquido são informações importantes para os usuários da contabilidade, e as mudanças promovidas pelo CPC afetaram significativamente o valor total desse grupo.

Já no segundo grupo não houve alinhamento entre o que os dados levantados apontaram e o que a percepção dos respondentes dos questionários indicou. Os dados demonstraram que as alterações introduzidas pelo CPC não afetaram de forma homogênea empresas de setores distintos, dificultaram a comparabilidade entre demonstrações contábeis de uma mesma empresa elaboradas antes e após tais alterações, assim como entre demonstrações contábeis de empresas pertencentes a segmentos distintos. A percepção apresentada dos participantes da pesquisa não permitiu afirmar existir consenso em concordar ou em discordar dessas afirmações, pois mostraram respostas consideravelmente dispersas demonstrando, portanto, que as percepções estão divididas.

No terceiro grupo tanto os dados levantados como a percepção dos professores de contabilidade sinalizaram ser importante conhecer a composição do patrimônio líquido das empresas e também transmitir esse conhecimento aos alunos. 
O distanciamento nos resultados ocorreu dessa forma, em parte das questões abordadas, que foi a parte que versou sobre como as alterações refletiram no patrimônio líquido de empresas pertencentes a segmentos distintos e também sobre a comparabilidade de demonstrações contábeis elaboradas antes e após as mudanças promovidas pelo CPC.

\subsection{Detalhamento das respostas por titulação dos respondentes}

As respostas aos questionários foram entregues pelos respondentes sob o compromisso de que, individualmente, os seus nomes são seriam divulgados.

Com a obtenção das respostas percebeu-se que parte considerável dos respondentes permitia o rastreamento da respectiva titulação por meio da plataforma lattes, do Conselho Nacional de Desenvolvimento Científico e Tecnológico - CNPQ. Tal plataforma tem o currículo denominado currículo lattes dos docentes, pesquisadores e estudantes do país. As informações são inseridas pelos próprios e ficam disponibilizadas para consulta pública no site do CNPQ.

Dessa maneira foi possível identificar a titulação de parte dos respondentes e comparar as respostas fornecidas com detalhamento maior. Dos 273 questionários respondidos, foi possível identificar a titulação de 188 respondentes. Assim, as respostas desses 188 foram divididas pelas titulações. A divisão foi feita em cinco categorias, que são: graduados e especialistas, mestres em contabilidade, mestres em outras áreas, doutores em contabilidade e doutores em outras áreas. A Tabela 27 apresenta a divisão desses 188 questionários.

Tabela 27- Divisão das respostas por titulação dos respondentes

\begin{tabular}{cc}
\hline Titulação & Respostas \\
\hline Graduado/Especialista & 57 \\
\hline Mestre em contabilidade & 71 \\
\hline Mestre em outras áreas & 37 \\
\hline Doutor em contabilidade & 13 \\
\hline Doutor em outras áreas & 10 \\
\hline Total & $\mathbf{1 8 8}$ \\
\hline
\end{tabular}

Com relação à parte das questões respondidas esperou-se não haver diferença entre as categorias pelo fato das respostas não terem sido dispersas, como foi o caso das questões 1,2 , 7 e 8 . Nas outras 4 questões, como as respostas se apresentaram mais divididas, era de se esperar que poderiam surgir diferenças entre as titulações. Na Tabela 28 são demonstradas as frequências relativas de respostas separadas por titulação: 
Tabela 28- Frequência relativa de respostas separadas por titulação dos respondentes

\begin{tabular}{|c|c|}
\hline & $\begin{array}{c}\text { Graduado/ } \\
\text { Especialista }\end{array}$ \\
\hline Questão & \\
\hline 1 & $0,0 \%$ \\
\hline 2 & $0,0 \%$ \\
\hline 3 & $0,0 \%$ \\
\hline 4 & $1,8 \%$ \\
\hline 5 & $1,8 \%$ \\
\hline 6 & $1,8 \%$ \\
\hline 7 & $7,0 \%$ \\
\hline 8 & $12,3 \%$ \\
\hline 9 & $75,4 \%$ \\
\hline $\mathrm{ABS}$ & $0,0 \%$ \\
\hline Total & $100,0 \%$ \\
\hline Questão & \\
\hline 1 & $0,0 \%$ \\
\hline 2 & $0,0 \%$ \\
\hline 3 & $0,0 \%$ \\
\hline 4 & $0,0 \%$ \\
\hline 5 & $0,0 \%$ \\
\hline 6 & $3,5 \%$ \\
\hline 7 & $14,0 \%$ \\
\hline 8 & $14,0 \%$ \\
\hline 9 & $68,4 \%$ \\
\hline $\mathrm{ABS}$ & $0,0 \%$ \\
\hline Total & $100,0 \%$ \\
\hline Questão & \\
\hline 1 & $0,0 \%$ \\
\hline 2 & $0,0 \%$ \\
\hline 3 & $5,3 \%$ \\
\hline 4 & $0,0 \%$ \\
\hline 5 & $12,3 \%$ \\
\hline 6 & $14,0 \%$ \\
\hline 7 & $29,8 \%$ \\
\hline 8 & $14,0 \%$ \\
\hline 9 & $22,8 \%$ \\
\hline $\mathrm{ABS}$ & $1,8 \%$ \\
\hline Total & $100,0 \%$ \\
\hline Questão & \\
\hline 1 & $3,5 \%$ \\
\hline 2 & $7,0 \%$ \\
\hline 3 & $7,0 \%$ \\
\hline 4 & $8,8 \%$ \\
\hline 5 & $19,3 \%$ \\
\hline 6 & $7,0 \%$ \\
\hline 7 & $17,5 \%$ \\
\hline 8 & $17,5 \%$ \\
\hline 9 & $8,8 \%$ \\
\hline ABS & $3,5 \%$ \\
\hline Total & $100,0 \%$ \\
\hline Questão & \\
\hline 1 & $5,3 \%$ \\
\hline 2 & $8,8 \%$ \\
\hline 3 & $10,5 \%$ \\
\hline 4 & $1,8 \%$ \\
\hline 5 & $12,3 \%$ \\
\hline 6 & $3,5 \%$ \\
\hline 7 & $19,3 \%$ \\
\hline 8 & $14,0 \%$ \\
\hline 9 & $22,8 \%$ \\
\hline ABS & $1,8 \%$ \\
\hline Total & $100,0 \%$ \\
\hline Questão & \\
\hline 1 & $14,0 \%$ \\
\hline 2 & $8,8 \%$ \\
\hline 3 & $7,0 \%$ \\
\hline 4 & $5,3 \%$ \\
\hline 5 & $15,8 \%$ \\
\hline 6 & $10,5 \%$ \\
\hline 7 & $8,8 \%$ \\
\hline 8 & $17,5 \%$ \\
\hline 9 & $12,3 \%$ \\
\hline $\mathrm{ABS}$ & $0,0 \%$ \\
\hline Total & $100,0 \%$ \\
\hline Questão & \\
\hline 1 & $0,0 \%$ \\
\hline 2 & $3,5 \%$ \\
\hline 3 & $0,0 \%$ \\
\hline 4 & $0,0 \%$ \\
\hline 5 & $5,3 \%$ \\
\hline 6 & $3,5 \%$ \\
\hline 7 & $14,0 \%$ \\
\hline 8 & $29,8 \%$ \\
\hline 9 & $43,9 \%$ \\
\hline ABS & $0,0 \%$ \\
\hline Total & $100,0 \%$ \\
\hline Questão & \\
\hline 1 & $0,0 \%$ \\
\hline 2 & $0,0 \%$ \\
\hline 3 & $1,8 \%$ \\
\hline 4 & $0,0 \%$ \\
\hline 5 & $0,0 \%$ \\
\hline 6 & $0,0 \%$ \\
\hline 7 & $5,3 \%$ \\
\hline 8 & $15,8 \%$ \\
\hline 9 & $77,2 \%$ \\
\hline $\mathrm{ABS}$ & $0,0 \%$ \\
\hline otal & $100,0 \%$ \\
\hline
\end{tabular}


Pela Tabela 28 apresentada anteriormente é possível perceber os resultados separados por categoria para as oito questões. No entanto, antes de qualquer tipo de interpretação se faz necessário relembrar que a coluna relacionada ao resultado geral não apresenta uma média ponderada do que foi respondido pelas cinco categorias. Isso porque há 273 respostas válidas no total, e somente foi possível categorizar 188 delas. Dessa maneira é possível compreender o motivo pelo qual alguns resultados em uma primeira análise podem parecer não fazer sentido, como é o caso, a título de ilustração, da escala de número 1 da questão 2 , em que apesar de não serem apresentados resultados nas cinco categorias, no resultado geral consta $0,4 \%$. Isso se deve ao fato de as respostas relacionadas a esse percentual estarem dentro do resultado geral, porém não estando incluídas nas respostas categorizadas.

Na questão de número 1, que afirma ser o PL uma informação importante para os usuários da contabilidade, as respostas foram concentradas próximas ao grau mais alto de concordância. Dentre as titulações notou-se que doutores pertencentes às áreas que não a contabilidade apresentaram uma concentração menor nesse grau de concordância, e apresentaram respostas próximas ao centro da escala, que significa não concordar nem discordar em frequência relativa pouco superior às demais categorias. Os doutores em outras áreas, juntamente com os mestres em contabilidade foram as categorias que apresentaram respostas menos concentradas no grau máximo de concordância com a afirmação presente na questão, representado pelo número 9. Os respondentes graduados e especialistas foram os que apresentaram respostas relativamente mais concentradas no ponto que representa grau máximo de concordância com a afirmação. O Gráfico 10 ilustra o exposto:

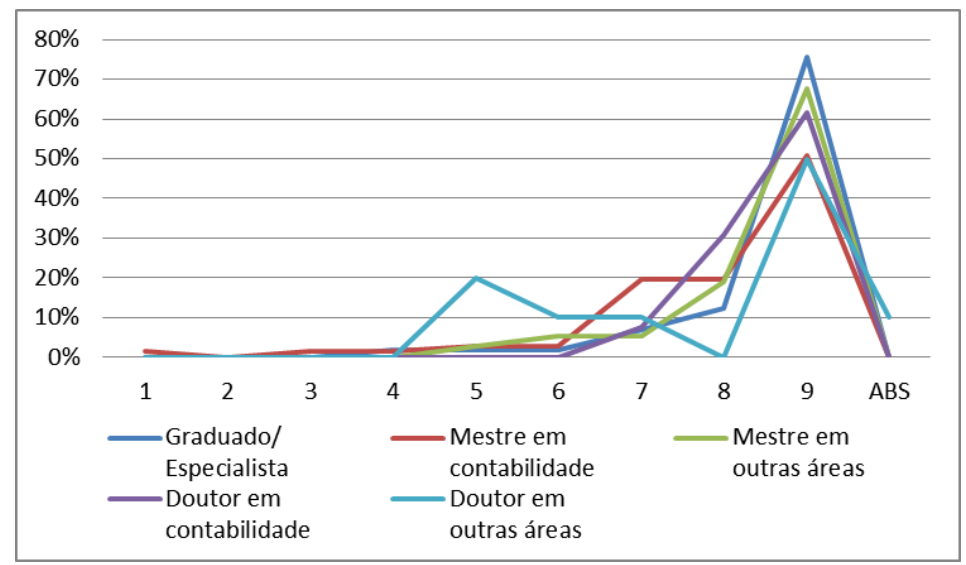

Gráfico 10 - Respostas da questão 1 categorizadas por titulação

Na questão de número 2, que afirma ser a composição do PL uma informação importante ao usuário da contabilidade, assim como o que aconteceu na questão 1, os doutores em áreas não 
contábeis apresentaram concentração menor ao redor das respostas relacionadas ao grau de concordância mais alto, apresentando frequência relativa pouco maior que as demais categorias no centro da escala, que significa não concordar nem discordar da afirmação. A categoria que apresentou maior concentração de suas respostas, no grau máximo de concordância com a afirmação, foi a dos graduados e especialistas. O Gráfico 11 evidencia essa pequena diferença entre as categorias presente nessa questão.

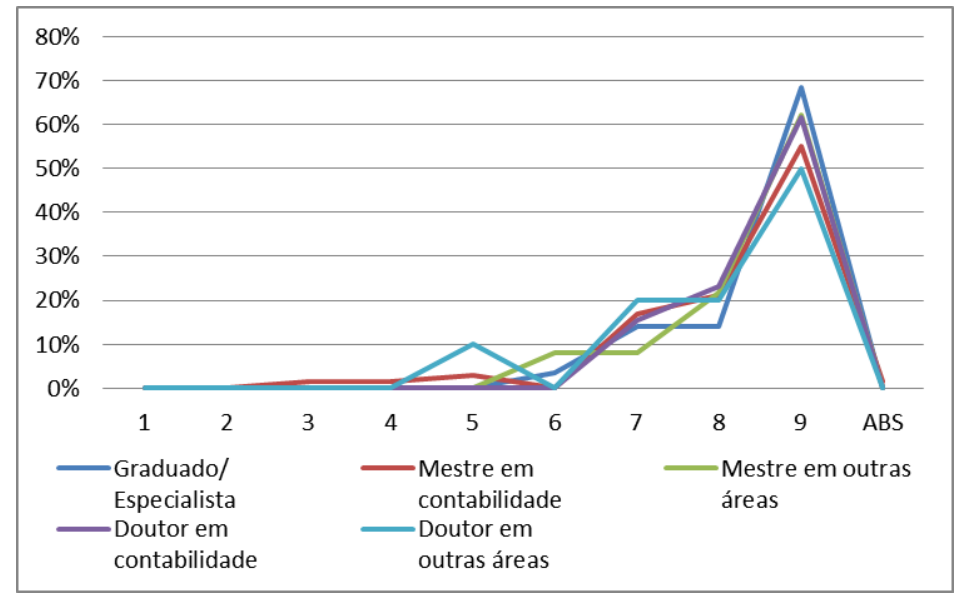

Gráfico 11 - Respostas da questão 2 categorizadas por titulação

Na questão de número 3, que afirma o total do PL ter sido significativamente alterado pelas alterações contábeis introduzidas pelo CPC, as respostas sem categorização haviam apresentado a maior parte das respostas localizadas em algum grau de concordância, e poucas respostas discordando da afirmação. Ao se realizar a categorização das respostas foi possível identificar uma dispersão com relação ao grau de concordância entre as categorias. Duas categorias destacaram-se por ter respostas mais próximas ao grau máximo de concordância, que foram a categoria de graduados e especialistas e também a categoria de doutores de outras áreas. As três categorias representadas por mestres em contabilidade ou não, e doutores em contabilidade, apresentaram respostas mais concentradas em um grau intermediário de concordância como evidencia o Gráfico 12: 


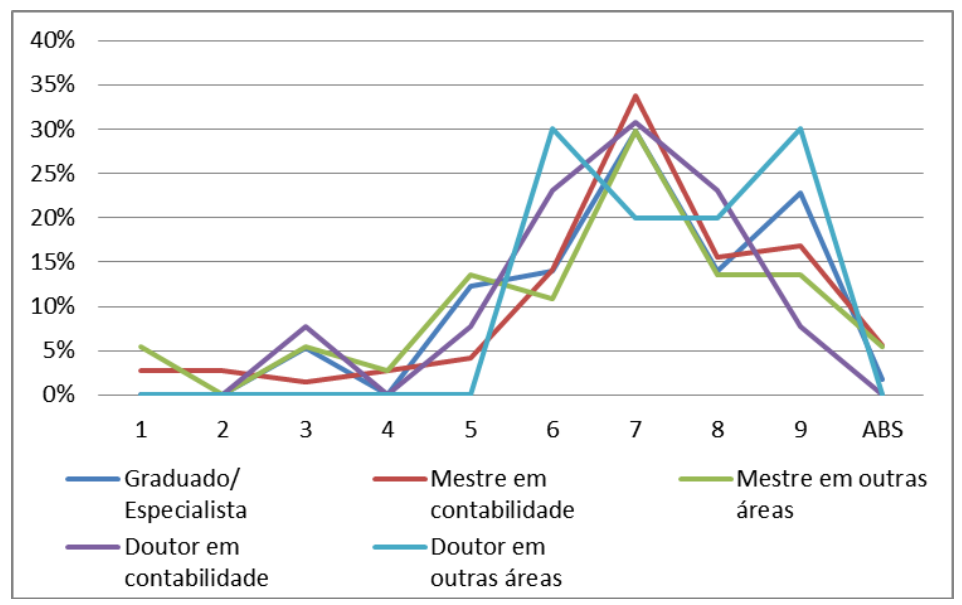

Gráfico 12- Respostas da questão 3 categorizadas por titulação

Na questão de número 4, que afirma as alterações provocadas no PL pelos pronunciamentos do CPC terem afetado de forma homogênea empresas de setores distintos, esperou-se uma diferença maior entre as respostas categorizadas por titulação, uma vez que as respostas sem a categorização já se apresentaram consideravelmente dispersas. Os doutores, tanto em contabilidade como em outras áreas, apresentaram uma concentração maior nas suas respostas, mas enquanto os doutores em contabilidade tiveram concentração maior próxima ao número 4 da escala, significando a forma mais amena de discordância, os doutores em outras áreas apresentaram maior concentração das respostas por volta do número 5 da escala, representando não discordar nem concordar. Nessa questão, uma informação importante é a de que os mestres em contabilidade e os doutores em contabilidade foram as categorias que apresentaram maior grau de discordância, com respostas indicando o número 1 da escala. Mestres em outras áreas e especialistas e graduados apresentaram maior concentração relacionada a algum grau de concordância. O Gráfico 13 demonstra as diferenças apresentadas nas respostas entre as categorias. 


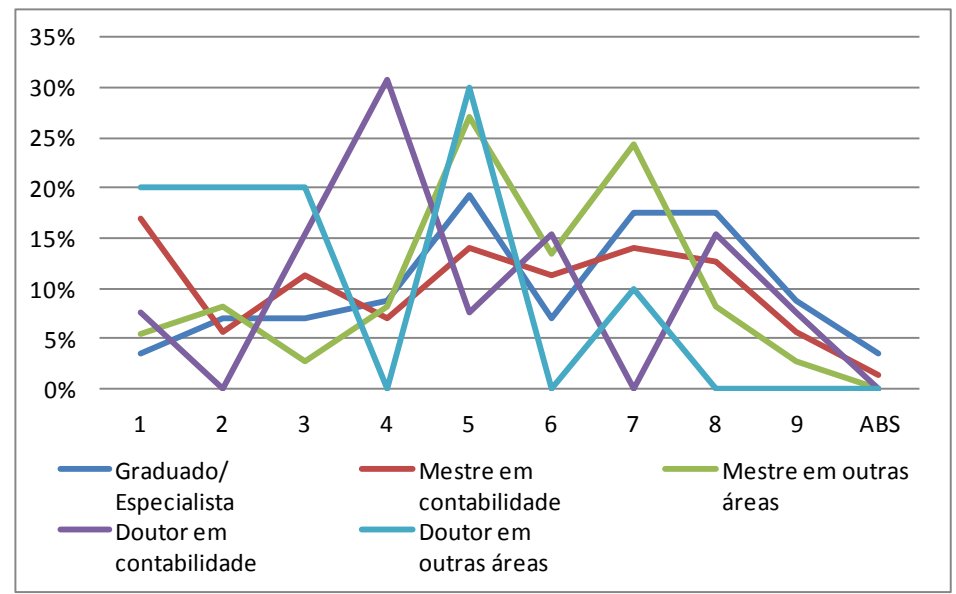

Gráfico 13- Respostas da questão 4 categorizadas por titulação

$\mathrm{Na}$ questão de número 5, que afirma ter sido dificultada a comparabilidade entre demonstrações contábeis de uma mesma empresa antes e depois das alterações promovidas pelo CPC, esperou-se uma diferença considerável entre as categorias, pois, assim como ocorrido na questão 4, as respostas sem a categorização já se apresentaram consideravelmente dispersas. A dispersão por categoria, porém não se apresentou tão presente como na questão anterior. Mais uma vez os doutores, tanto em contabilidade como em outras áreas, apresentaram as respostas mais concentradas em um único ponto da escala, que foi o de número 6, significando um grau baixo de concordância com a afirmação proposta na questão. Os mestres em outras áreas apresentaram sua maior concentração de respostas em um grau acima, significando um nível de concordância um pouco maior, embora essa concentração não tenha se apresentado tão acentuada como no caso das respostas dos doutores. Os graduados e especialistas apresentaram respostas mais concentradas no ponto mais alto da escala, que significa grau máximo de concordância com a afirmação proposta. Os mestres em contabilidade foram a categoria que apresentou menos concentração em um único ponto da escala, mas ainda assim foi possível identificar um ponto de destaque nessa categoria, que foi o número 5, que representa o meio da escala, não significando grau algum de concordância ou discordância. O Gráfico14 pode reproduzir essa diferença de concentração de respostas entre as categorias. 


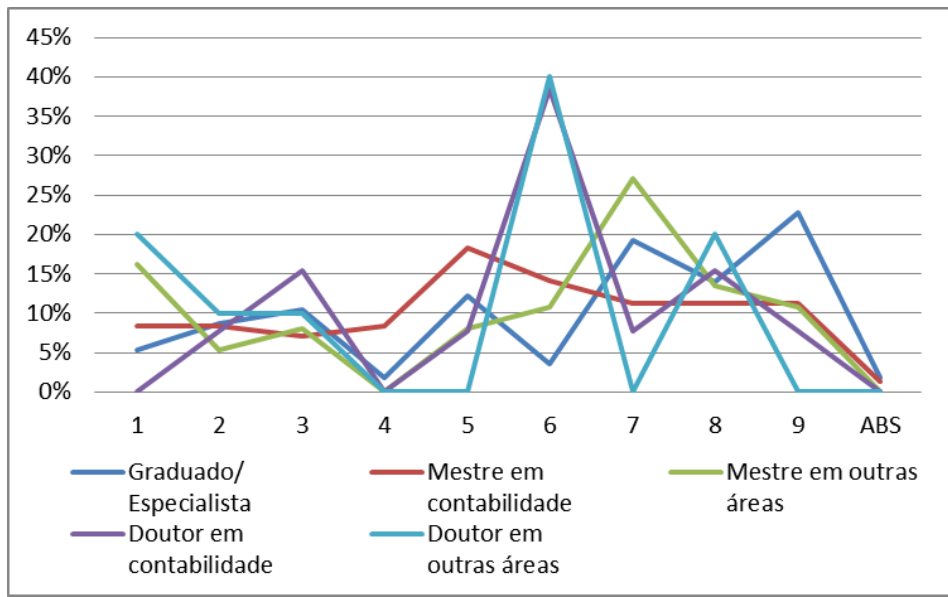

Gráfico 14- Respostas da questão 5 categorizadas por titulação

$\mathrm{Na}$ questão de número 6, que afirma ter sido dificultada a comparabilidade entre demonstrações contábeis entre empresas de segmentos distintos depois das alterações promovidas pelo CPC, tal como ocorrido na questão 5, esperou-se uma diferença considerável entre as categorias, uma vez que as respostas sem a categorização já se apresentaram consideravelmente dispersas. A dispersão por categoria confirmou o esperado. Os doutores em contabilidade foram a categoria que mais concentrou respostas em algum ponto da escala no sentido de discordar da afirmação. Curiosamente, também, foi a categoria que mais concentrou respostas em um único ponto significando concordância, ainda que discreta, no número 6 da escala. Os doutores em contabilidade tiveram respostas bem concentradas em dois pontos da escala, os de número 2 e 6 , evento que explica o motivo de surgirem como categoria que mais teve respostas em algum ponto específico da escala representando discordância e também concordância, o que não aconteceu com os professores graduados e especialistas, que tiveram respostas mais distribuídas na escala. A categoria dos mestres em outras áreas foi a que mais reuniu respostas no grau intermediário da escala, não significando concordância ou discordância. O Gráfico 15 ilustra a dispersão das respostas. 


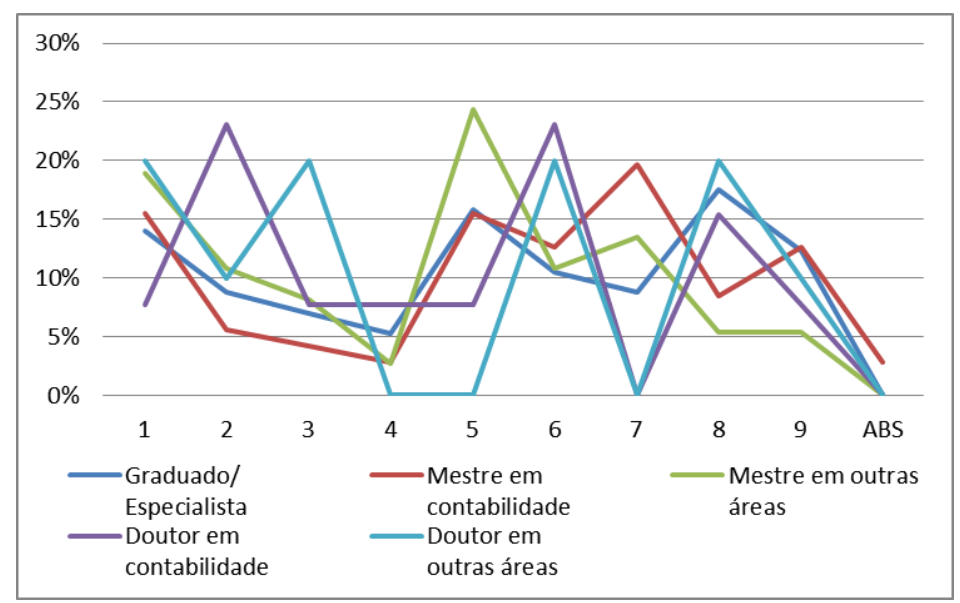

Gráfico 15 - Respostas da questão 6 categorizadas por titulação

Na questão de número 7, que afirma ser mais importante conhecer a composição do PL das empresas após a introdução das normas do CPC, aproximadamente $80 \%$ das respostas se concentraram em algum grau de concordância com a afirmativa. Isso leva à expectativa que as respostas categorizadas não se diferenciem tanto como nas questões de 4 a 6 . Essa expectativa se confirmou, mas ainda assim as respostas de três categorias se destacaram. A categoria que mais reuniu respostas no número 5 da escala apresentando, assim, indefinição ou indiferença foi a de doutores em contabilidade. A categoria que mais concentrou respostas em algum nível de discordância com a afirmativa da questão foi a de doutores em outras áreas. E os graduados e especialistas representaram a categoria que mais concentrou respostas no número 9 da escala que representa o grau máximo de concordância com a afirmativa. O Gráfico16 ilustra esse comportamento.

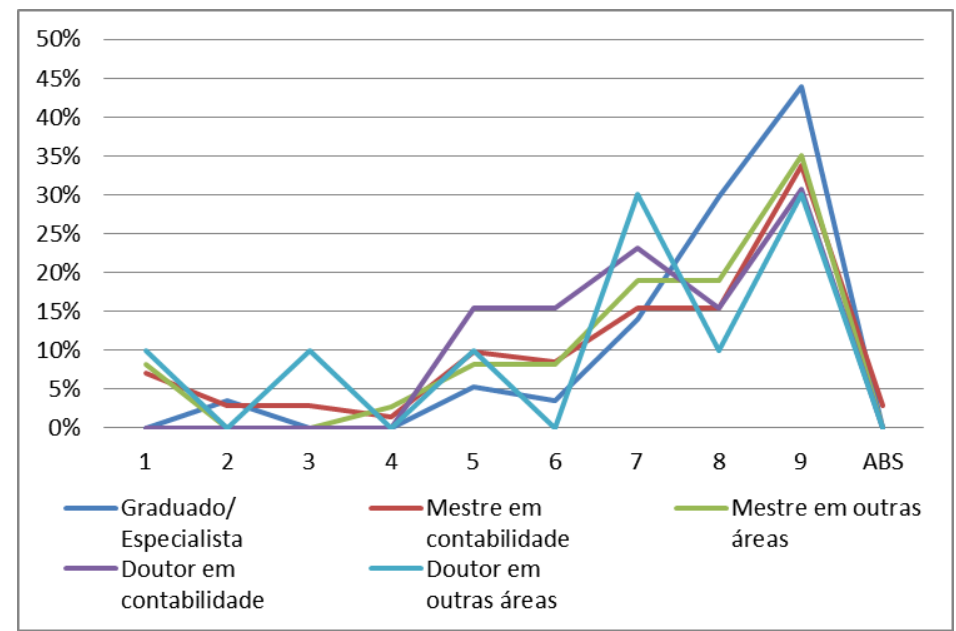

Gráfico 16 - Respostas da questão 7 categorizadas por titulação

A questão de número 8, que afirma ser importante transmitir aos alunos conhecimentos relacionados à composição do PL e como essa composição pode afetar a utilização das 
informações contábeis, foi a que apresentou resultados mais reunidos em um único ponto. Pouco mais de $88 \%$ das respostas ficou concentrado em dois números da escala, que foram o 8 e o 9, que são os dois números que representam o maior grau de concordância com a afirmativa apresentada. Das cinco categorias verificadas, duas delas não tiveram suas respostas tão agrupadas nesses dois números da escala, apesar de também terem apresentado grande concentração. A primeira delas é a de doutores em outras áreas, que apresentou respostas mais diluídas em outros níveis de concordância da escala e também foi a categoria que relativamente apresentou mais respostas no número 5 da escala, que significa não concordar nem discordar. A segunda é a de doutores em contabilidade que apresentou uma concentração no número 7 da escala superior às demais categorias. Por se tratar de uma questão que apresentou quase que unanimidade ao se referir a algum grau de concordância, quando se analisa o total de respostas sem categorização, esse detalhamento por categorias permite identificar, ao menos com relação às respostas que foram passíveis de identificação, quais as categorias que apresentaram algum grau de discordância. E foram duas: os graduados com $1,8 \%$ das respostas de sua categoria, e os mestres em contabilidade com $2,8 \%$ das respostas de sua categoria. O Gráfico 17 reflete esse posicionamento quase unânime dos respondentes.

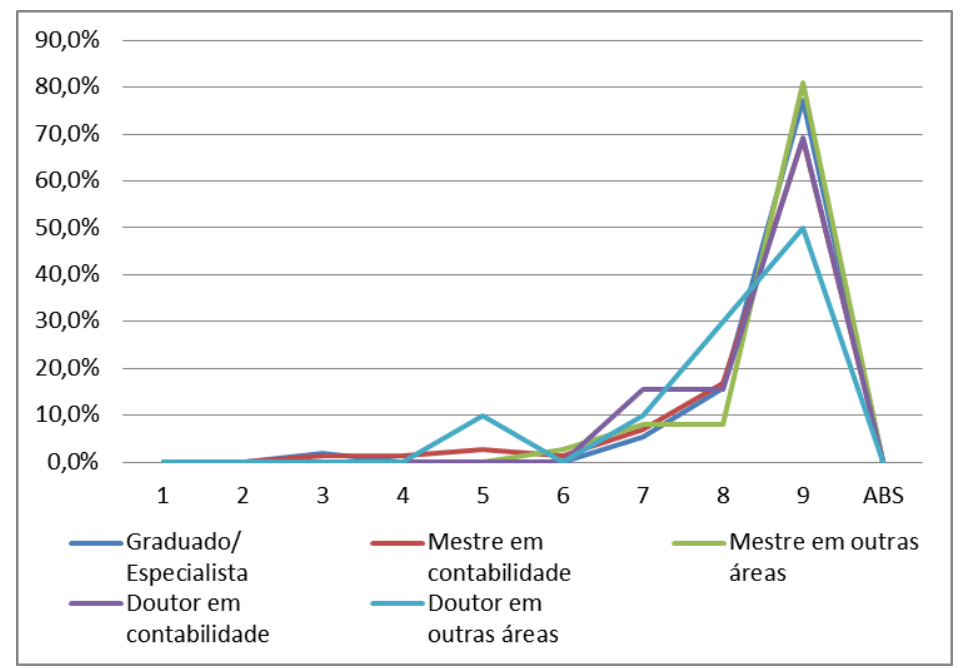

Gráfico 17 - Respostas da questão 8 categorizadas por titulação

A separação por titulação realizada neste tópico apresentou resultados relevantes no sentido de revelar indícios de que professores com títulos diferentes podem perceber de forma distinta as questões relacionadas à contabilidade, mais especificamente as mudanças pelas quais a contabilidade passa atualmente. As questões de números 4, 5 e 6 revelam que podem existir casos nos quais as interpretações ou percepções podem ser bem diferentes entre as categorias. 
Esse levantamento por categorias não pretendeu esgotar o assunto, mas, ao contrário, pretendeu despertar curiosidade sobre ele ao realçar a questão dessa forma. Não pretendeu igualmente julgar se estão certos ou errados, mas sim fazer uma aproximação da questão. Os motivos e as consequências dessas diferenças são fatores determinantes no comportamento atual dos docentes que por sua vez levam à sala de aula suas percepções e formam novos profissionais, e o estudo desses fatores pode levar a descobertas sobre as condições da profissão e dos profissionais da área contábil.

\subsection{Detalhamento das respostas por região geográfica dos respondentes}

Adicionalmente ao detalhamento das respostas por titulação dos respondentes foi possível igualmente elaborar detalhamento por regiões geográficas dos respondentes.

A região geográfica foi informada por boa parte daqueles que se dispuseram a responder ao questionário. Do total de 273 questionários respondidos foi possível identificar a região geográfica de259 deles, quase $95 \%$ do total. Assim, as respostas destes 259 foram divididas pelas regiões geográficas do Brasil, e obteve-se a seguinte divisão:

Tabela 29- Divisão das respostas por regiões geográficas

\begin{tabular}{|c|c|}
\hline Região & Respostas \\
\hline Norte & 12 \\
\hline Nordeste & 47 \\
\hline Centro-Oeste & 24 \\
\hline Sudeste & 100 \\
\hline Sul & 76 \\
\hline Total & $\mathbf{2 5 9}$ \\
\hline
\end{tabular}

Assim como percebido no detalhamento por titulação dos respondentes, houve questões nas quais se esperou não haver diferença entre as regiões pelo fato das respostas não terem sido dispersas, como foi o caso das questões 1, 2, 7 e 8. Nas outras 4 questões, como as respostas se apresentaram mais divididas, era de se esperar que poderiam surgir diferenças entre as titulações. No entanto, o detalhamento evidenciou haver um pouco mais de dispersão nas respostas separadas por regiões do que nas respostas separadas por titulação dos respondentes.

Com o propósito de se evitar repetições, optou-se por não apresentar gráficos e análises das respostas com comportamento semelhante às respostas já apresentadas relacionadas à divisão de respostas por titulação, que foram as respostas das questões 1, 2, 7 e 8 . Ainda assim são 
demonstradas na Tabela 30 as frequências relativas de respostas separadas por regiões do país, relacionadas às oito respostas.

Tabela 30 - Frequência relativa de respostas separadas por região geográfica dos respondentes

\begin{tabular}{|c|c|}
\hline & Norte \\
\hline Questão 1 & \\
\hline 1 & $0,0 \%$ \\
\hline 2 & $0,0 \%$ \\
\hline 3 & $0,0 \%$ \\
\hline 4 & $0,0 \%$ \\
\hline 5 & $0,0 \%$ \\
\hline 6 & $0,0 \%$ \\
\hline 7 & $8,3 \%$ \\
\hline 8 & $25,0 \%$ \\
\hline 9 & $66,7 \%$ \\
\hline$A B S$ & $0,0 \%$ \\
\hline Total & $100,0 \%$ \\
\hline Questão 2 & \\
\hline 1 & $0,0 \%$ \\
\hline 2 & $0,0 \%$ \\
\hline 3 & $0,0 \%$ \\
\hline 4 & $0,0 \%$ \\
\hline 5 & $0,0 \%$ \\
\hline 6 & $0,0 \%$ \\
\hline 7 & $16,7 \%$ \\
\hline 8 & $25,0 \%$ \\
\hline 9 & $58,3 \%$ \\
\hline$A B S$ & $0,0 \%$ \\
\hline Total & $100,0 \%$ \\
\hline Questão 3 & \\
\hline 1 & $0,0 \%$ \\
\hline 2 & $0,0 \%$ \\
\hline 3 & $0,0 \%$ \\
\hline 4 & $0,0 \%$ \\
\hline 5 & $8,3 \%$ \\
\hline 6 & $16,7 \%$ \\
\hline 7 & $33,3 \%$ \\
\hline 8 & $8,3 \%$ \\
\hline 9 & $33,3 \%$ \\
\hline ABS & $0,0 \%$ \\
\hline Total & $100,0 \%$ \\
\hline Questão 4 & \\
\hline 1 & $8,3 \%$ \\
\hline 2 & $0,0 \%$ \\
\hline 3 & $8,3 \%$ \\
\hline 4 & $16,7 \%$ \\
\hline 5 & $16,7 \%$ \\
\hline 6 & $16,7 \%$ \\
\hline 7 & $8,3 \%$ \\
\hline 8 & $16,7 \%$ \\
\hline 9 & $8,3 \%$ \\
\hline ABS & $0,0 \%$ \\
\hline Total & $100,0 \%$ \\
\hline Questão 5 & \\
\hline 1 & $16,7 \%$ \\
\hline 2 & $0,0 \%$ \\
\hline 3 & $8,3 \%$ \\
\hline 4 & $0,0 \%$ \\
\hline 5 & $16,7 \%$ \\
\hline 6 & $0,0 \%$ \\
\hline 7 & $8,3 \%$ \\
\hline 8 & $25,0 \%$ \\
\hline 9 & $25,0 \%$ \\
\hline$A B S$ & $0,0 \%$ \\
\hline Total & $100,0 \%$ \\
\hline Questão 6 & \\
\hline 1 & $16,7 \%$ \\
\hline 2 & $8,3 \%$ \\
\hline 3 & $0,0 \%$ \\
\hline 4 & $0,0 \%$ \\
\hline 5 & $33,3 \%$ \\
\hline 6 & $0,0 \%$ \\
\hline 7 & $8,3 \%$ \\
\hline 8 & $16,7 \%$ \\
\hline 9 & $16,7 \%$ \\
\hline ABS & $0,0 \%$ \\
\hline Total & $100,0 \%$ \\
\hline Questão 7 & \\
\hline 1 & $8,3 \%$ \\
\hline 2 & $0,0 \%$ \\
\hline 3 & $0,0 \%$ \\
\hline 4 & $0,0 \%$ \\
\hline 5 & $0,0 \%$ \\
\hline 6 & $16,7 \%$ \\
\hline 7 & $8,3 \%$ \\
\hline 8 & $16,7 \%$ \\
\hline 9 & $50,0 \%$ \\
\hline$A B S$ & $0,0 \%$ \\
\hline Total & $100,0 \%$ \\
\hline Questão 8 & \\
\hline 1 & $0,0 \%$ \\
\hline 2 & $0,0 \%$ \\
\hline 3 & $0,0 \%$ \\
\hline 4 & $0,0 \%$ \\
\hline 5 & $0,0 \%$ \\
\hline 6 & $0,0 \%$ \\
\hline 7 & $0,0 \%$ \\
\hline 8 & $8,3 \%$ \\
\hline 9 & $91,7 \%$ \\
\hline$A B S$ & $0,0 \%$ \\
\hline Total & $100,0 \%$ \\
\hline
\end{tabular}


Os resultados separados por regiões demográficas são apresentados pela tabela anterior, e a mesma consideração realizada na separação por titulação merece ser abordada. A coluna relacionada ao resultado geral não apresenta uma média ponderada do que foi respondido pelas cinco regiões, pois há 273 respostas válidas no total e somente 259 delas foram categorizadas.

A questão de número 3 que afirma que o total do PL foi significativamente alterado pelas alterações contábeis introduzidas pelo $\mathrm{CPC}$, e as suas respostas apresentaram um comportamento menos alinhado do que o ocorrido com as questões 1 e 2, apresentando uma dispersão um pouco maior entre as regiões. A região centro-oeste foi a que relativamente mais apresentou respostas em um ponto significando discordância. A região nordeste foi a que mais apresentou respostas localizadas próximas ao número 5 que significa não concordar nem discordar com a afirmação. A região sul foi a que apresentou respostas mais reunidas em um único ponto, de número 7, significando concordância parcial com a afirmativa. E a região norte foi a que relativamente mais apresentou respostas ligadas ao nível máximo de concordância, o número 9, como apresenta o Gráfico 18:

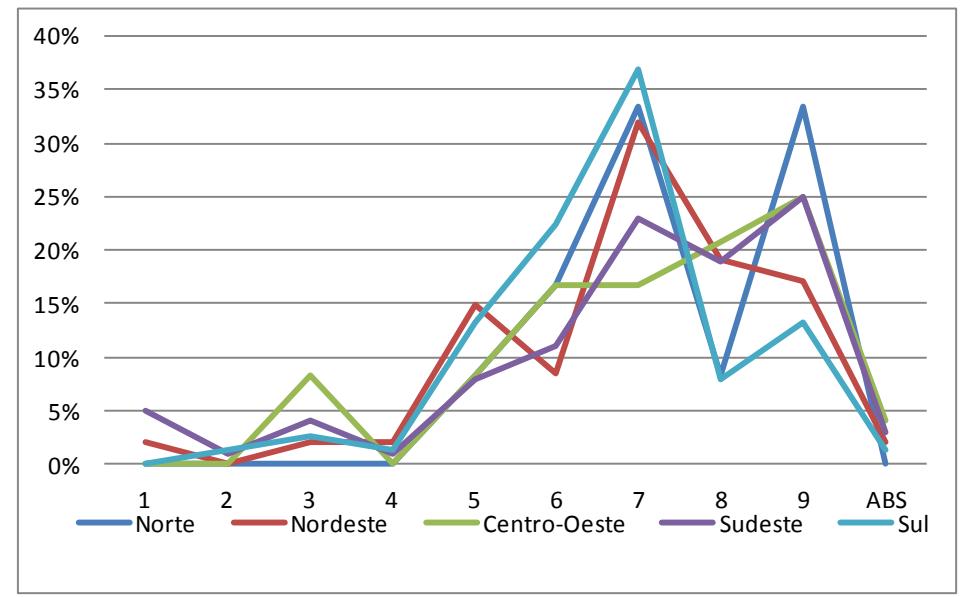

Gráfico 18 - Respostas da questão 3 categorizadas por regiões geográficas

Na questão de número 4, que afirma as alterações provocadas no PL pelos pronunciamentos do CPC terem afetado de forma homogênea empresas de setores distintos, assim como ocorrido na categorização de respostas por titulação dos respondentes, também houve considerável diferença entre as respostas por região. No geral, as respostas foram aglomeradas em torno do centro da escala, indicando baixa concordância ou discordância, ou ainda certa indefinição. A região que apresentou mais respostas localizadas no centro da escala foi a região nordeste. A região centro-oeste teve significativa reunião de respostas em escalas que 
representavam baixa concordância, mais especificamente números 6 e 7. As demais regiões não apresentaram respostas tão reunidas em um ponto da escala como essas duas, tendo respostas mais diluídas na escala. O Gráfico 19 representa como essas duas regiões, nordeste e centro-oeste, apresentaram maior concentração em suas respostas comparando-se com as demais.

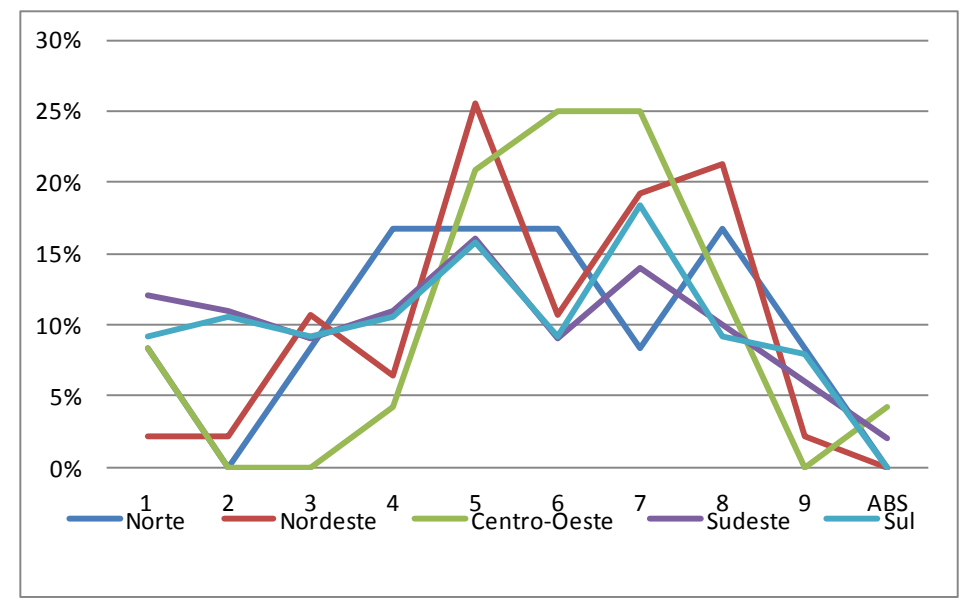

Gráfico 19 - Respostas da questão 4 categorizadas por regiões geográficas

$\mathrm{Na}$ questão de número 5, que afirma ter sido dificultada a comparabilidade entre demonstrações contábeis de uma mesma empresa antes e depois das alterações promovidas pelo CPC, esperou-se igualmente uma diferença considerável entre as categorias, pois como ocorrido na questão 4, as respostas sem a categorização já se apresentaram consideravelmente dispersas. Foi possível identificar uma certa polarização das respostas entre discordância e concordância com a afirmativa, não tendo as respostas ficado tão aglomeradas em torno do meio da escala como ocorreu na questão 4. As regiões norte e centro-oeste foram as que mais apresentaram número relativo de respostas no grau máximo de discordância da escala, e a região norte também foi responsável pelo maior número relativo de respostas relativas ao número mais alto da escala, significando o maior nível de concordância com a afirmativa apresentada na questão. As regiões nordeste e centro-oeste apresentaram respostas mais concentradas em grau moderado de concordância, enquanto a região sudeste apesar de concentrar a maioria de suas respostas em graus da escala representando concordância demonstrou comportamento mais distribuído dos que as demais regiões. O Gráfico 20 pode expressar essa diferença de concentração de respostas entre as categorias. 


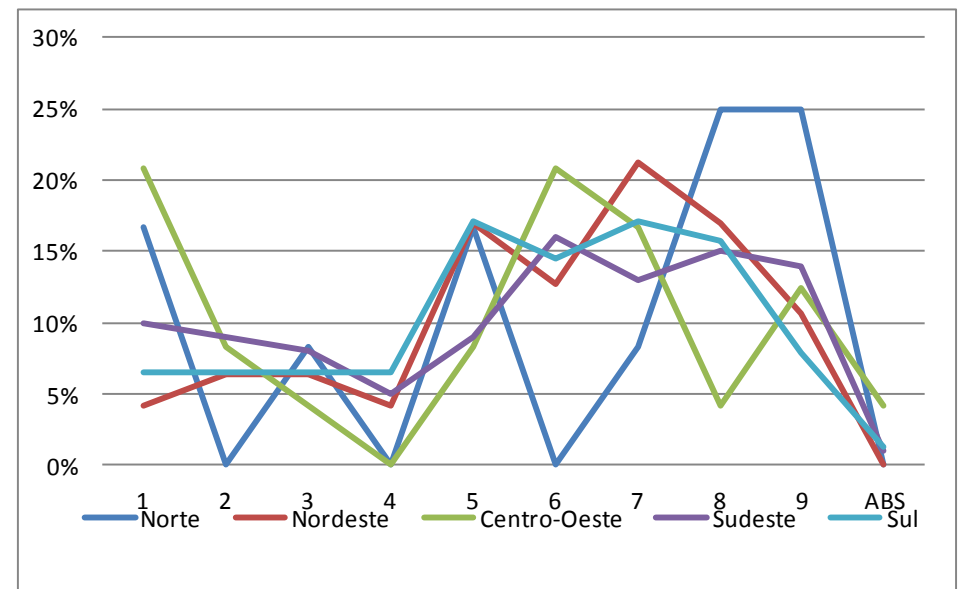

Gráfico 20 - Respostas da questão 5 categorizadas por regiões geográficas

$\mathrm{Na}$ questão de número 6 , que afirma ter sido dificultada a comparabilidade entre demonstrações contábeis entre empresas de segmentos distintos depois das alterações promovidas pelo CPC, tal como ocorrido na questão anterior, esperou-se uma diferença considerável entre as categorias. A dispersão das respostas entre as categorias foi confirmada, sendo a região norte a que mais apresentou respostas reunidas no meio da escala, indicando não concordar ou discordar. A região nordeste foi a que apresentou maior número relativo de respostas relacionadas a um grau da escala significando concordância com a afirmação, mais especificamente no número 8. A região centro-oeste foi a que relativamente mais apresentou respostas de representando maior grau de discordância. As regiões sul e sudeste apresentaram repostas mais distribuídas ao longo da escala do que as três anteriormente citadas. O gráfico seguinte ilustra a apresentação das respostas.

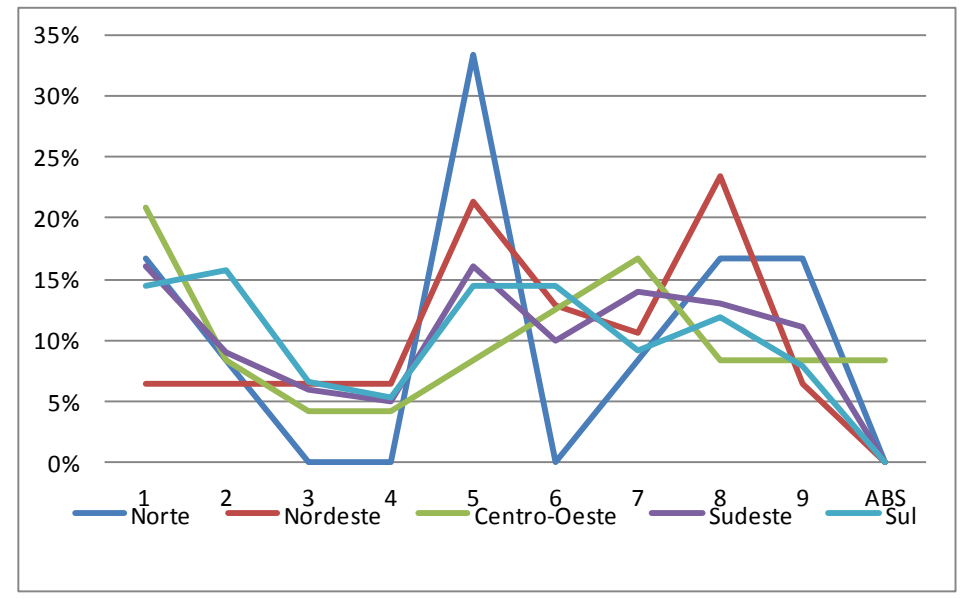

Gráfico 21 - Respostas da questão 6 categorizadas por regiões geográficas

A separação por regiões geográficas elaborada neste tópico demonstrou que a percepção sobre as alterações no patrimônio líquido das empresas é diferente entre essas regiões. Neste estudo, 
não houve o objetivo de se investigar os motivos que levaram a essa diferença, mas, ao contrário, limitou-se a explorar a questão no sentido de coletar indícios sobre a possibilidade da existência de percepções diferentes sobre a questão.

Percebeu-se que por mais concentrada que uma resposta tenha se apresentado na pesquisa sem divisão por regiões, houve espaço para que entre essas regiões comportamento ou percepções distintas se instalassem. E como mencionado no tópico anterior, essas percepções de docentes acabam por se transmitir aos alunos e consequentemente ao mercado, decorrendo daí a relevância da questão. 



\section{CONSIDERAÇÕES FINAIS E CONCLUSÕES}

O presente estudo teve por objetivo identificar a extensão das alterações promovidas no patrimônio líquido das companhias abertas a partir de 2010, e como os docentes de contabilidade perceberam tais alterações.

Os principais resultados da pesquisa foram explorados nos capítulos 3 e 4 e, aqui, de forma reduzida, serão destacados alguns deles.

Analisando-se as informações de companhias abertas relativas ao ano de 2010, o primeiro a incorporar todas as alterações no PL atualmente em vigor, foi possível identificar que a composição do patrimônio líquido dessas companhias em alguns casos sofreu considerável alteração. Comparando-se o valor da somatória do patrimônio líquido das empresas estudas da forma que foram publicados em 2010 com o valor da somatória do patrimônio líquido dessas mesmas empresas excluindo-se componentes introduzidos pela nova normatização contábil houve uma redução de $8,9 \%$.

Identificou-se também que as alterações no patrimônio líquido não impactaram companhias abertas de forma homogênea, sendo possível perceber que setores distintos apresentaram efeitos diversos, não sendo possível afirmar que as alterações exerceram o mesmo impacto ou, impacto na mesma intensidade, em todas as companhias abertas. As companhias foram divididas em 8 setores de acordo com as atividades que exercem e classificação presente na BM\&FBovespa. A conta de ajuste de avaliação patrimonial chegou a representar $8 \%$ do patrimônio líquido em companhias atuantes no setor bancário e financeiro, enquanto não chegou a representar $1 \%$ nos setores compostos por companhias do segmento de petróleo e gás e também no segmento de comércio em geral. $\mathrm{O}$ valor de outros resultados abrangentes consumiu $4 \%$ do patrimônio líquido de empresas do setor de indústrias em geral, enquanto se apresentou positivo em companhias dos setores de exploração de concessões e de bancos e atividades financeiras. A conta de dividendo adicional proposto representou 5\% do patrimônio líquido do setor das empresas agrícolas e do segmento alimentício e não chegou a representar $1 \%$ do patrimônio líquido nos setores formados por empresas dos ramos de construção civil e exploração de imóveis, serviços em geral e transporte, e também petróleo e gás. Os custos de transação não chegaram a representar $1 \%$ do patrimônio líquido de nenhum setor, embora, individualmente, esse valor chegou a consumir até 5\% do patrimônio líquido 
de uma companhia. A evidenciação de valores relacionados à remuneração baseada em ações não atingiu a representatividade de $1 \%$ do patrimônio líquido de nenhum setor analisado. A participação de acionistas não controladores alcançou $12 \%$ do patrimônio líquido de companhias industriais em geral, ao mesmo tempo que manteve representatividade de $1 \%$ do patrimônio líquido de empresas do setor de serviços em geral e transportes, assim como de empresas do setor de petróleo e gás.

$\mathrm{Na}$ sequência, analisou-se a percepção dos usuários das informações contábeis, mais especificamente docentes de contabilidade, acerca das citadas mudanças com a utilização de questionários.

As respostas dos questionários apontaram no sentido de existir consenso entre os docentes de contabilidade sobre o valor do patrimônio líquido ser uma informação importante para os usuários de contabilidade, com 91\% de respostas apresentando algum grau de concordância. Apresentaram haver consenso sobre a composição do PL ser importante para os usuários da contabilidade e pouco mais de $60 \%$ delas expressaram o grau mais alto de concordância com a afirmação, e as três respostas com maior grau de concordância foram responsáveis por 93,7\% do total. Do total das respostas, $79,4 \%$ apresentaram algum grau de concordância com a afirmação de que as alterações provocadas no PL das empresas pelos pronunciamentos do CPC afetaram, significativamente, o valor total desse grupo. Aproximadamente, $80 \%$ dos respondentes apresentaram algum grau de concordância com a afirmação de que conhecer a composição do PL e, não somente, seu valor total tornou-se mais importante após as alterações introduzidas pelos pronunciamentos do CPC, e pouco mais de $95 \%$ dos respondentes apresentaram algum grau de concordância com a afirmação sobre ser importante transmitir aos alunos conhecimentos relacionados à composição do PL e como tal composição pode afetar a utilização das informações contábeis.

Foram identificadas também questões nas quais não existe consenso entre os respondentes. $\mathrm{Na}$ questão que afirma terem as alterações provocadas no PL das empresas pelos pronunciamentos do CPC afetado de forma homogênea empresas de setores distintos, 34\% dos respondentes apresentaram algum grau de discordância enquanto 47\% apresentaram algum grau de concordância, sendo que $16 \%$ apresentaram o grau intermediário da escala não representando nem concordância nem discordância. Na questão em que se afirma que as alterações provocadas no PL pelos pronunciamentos do CPC dificultaram a comparabilidade 
entre demonstrações contábeis da própria empresa elaboradas antes e após tais alterações, $28 \%$ das respostas apresentaram algum grau de discordância e 57\% delas algum grau de concordância. Na questão que afirma as alterações introduzidas no PL terem dificultado a comparabilidade entre demonstrações contábeis de empresas pertencentes a segmentos distintos o grau de escala que apresentou individualmente maior número de respostas foi exatamente o intermediário que não representa concordância ou discordância, com pouco mais de $16 \%$ do total de respostas. Nessa mesma questão, 35\% dos respondentes apresentaram algum grau de discordância com a afirmação proposta e $47 \%$ algum grau de concordância.

Adicionalmente foram detalhadas as respostas fornecidas pelos docentes de contabilidade conforme titulação e região geográfica dos respondentes. Nessa etapa não foi possível categorizar todas as respostas obtidas, pois a identificação ao se responder aos questionários foi opcional. De um total de 273 questionários respondidos foi possível categorizar 188 por titulação e 259 por regiões geográficas do país.

Essa categorização permitiu levantar indícios que a titulação e a região geográfica dos respondentes influenciam na percepção que possuem sobre as questões pesquisadas. Tal categorização mostrou-se importante, uma vez que o docente leva para a sala de aula aquilo que possui, e transmite aos alunos. Se algo influencia sua percepção acabará por influenciar também a percepção dos alunos, motivo importante que justificaria um estudo à parte, já que não está contido no objetivo deste.

Tanto na categorização por titulação dos docentes como na categorização por regiões geográficas, nas questões onde não houve um consenso dos docentes nas respostas, ficou evidenciada uma dispersão entre as respostas categorizadas. Isso demonstra que ao se detalhar as respostas a dispersão se torna ainda mais acentuada, levando a constatar a existência de posicionamentos diferentes entre docentes com titulações e regiões geográficas distintas.

Ao se confrontar as respostas nas quais não houve consenso com o levantamento realizado com base nos dados das empresas, percebe-se que essas respostas não estão alinhadas com o que ocorreu nessas empresas. Nas respostas não houve consenso, porém o levantamento das informações demonstrou que os pronunciamentos do CPC não afetaram de forma homogênea empresas de setores distintos, que as alterações provocadas no PL das empresas pelos 
pronunciamentos do CPC aumentaram o grau de dificuldade para se comparar demonstrações contábeis da própria empresa elaboradas antes e após tais alterações, assim como aumentaram a dificuldade para se comparar demonstrações contábeis de empresas pertencentes a segmentos distintos.

Conclui-se, assim, que as mudanças introduzidas no patrimônio líquido das companhias abertas podem ser consideráveis, variam em função dos segmentos em que as companhias estão inseridas, e a percepção dos docentes em contabilidade acerca dessas mudanças não pode ser considerada consensual ou unânime com relação a alguns dos pontos pesquisados, revelando, dessa maneira, algum distanciamento do que foi levantado pelas demonstrações contábeis dessas companhias. 


\section{REFERÊNCIAS}

ABE, Cesar Henrique Shogi. Teorias contábeis sobre o patrimônio líquido e teoria da renda-acréscimo patrimonial: um estudo interdisciplinar. 2007. Dissertação (Mestrado em Ciências Contábeis) - Programa de Pós-Graduação em Ciências Contábeis, Departamentos de Contabilidade e Atuária, Faculdade de Economia, Administração e Contabilidade da Universidade de São Paulo.

ACUÑA, Benjamin Cristobal Mardine; CRUZ, Cláudia Ferreira da; OVIEDO, Thiago Gutschov; SALOTTI, Bruno Meirelles. Impactos da transição de normas contábeis brasileiras sobre o potencial de distribuição de dividendos das companhias componentes do IBrX-100. In: $12^{\circ}$ Congresso USP de Controladoria e Contabilidade, Julho de 2012, São Paulo. Anais... São Paulo: USP, 2012. Disponível em: < http://www.congressousp.fipecafi.org/artigos122012/505.pdf >. Acesso em 26/02/2013

ALBANEZ, Tatiana. Impactos da assimetria de informação na estrutura de capital de empresas brasileiras de capital aberto. 2008. Dissertação (Mestrado em Controladoria e Contabilidade) - Programa de Pós-Graduação em Ciências Contábeis, Departamentos de Contabilidade e Atuária, Faculdade de Economia, Administração e Contabilidade de Ribeirão Preto da Universidade de São Paulo.

ALBANEZ, Tatiana; VALLE, Mauricio Ribeiro do. Impactos da assimetria de informação na estrutura de capital de empresas brasileiras abertas. Revista Contabilidade \& Finanças USP. São Paulo, v.20, n.51, p.6-27, setembro/dezembro 2009.

ALCADE, Adriano. Efeitos hierárquicos na margem Ebitda: influências do tempo, firma e setor. 2010. Dissertação (Mestrado em Ciências Contábeis) - Programa de PósGraduação em Ciências Contábeis, Departamentos de Contabilidade e Atuária, Faculdade de Economia, Administração e Contabilidade da Universidade de São Paulo.

ALMEIDA, José Elias Feres de. Qualidade da informação contábil em ambientes competitivos. 2010. Tese (Doutorado em Ciências Contábeis) Faculdade de Economia, Administração e Contabilidade da Universidade de São Paulo - FEA/USP. São Paulo.

ALMEIDA, Marcelo Cavalcanti. Manual prático de interpretação contábil da lei societária. São Paulo: Atlas, 2010.

AMORIM, Ana Luísa Gambi Cavallari de. Análise da relação entre informação contábil e o risco sistemático. 2010. Tese (Doutorado em Controladoria e Contabilidade) - Programa de Pós-Graduação em Ciências Contábeis, Departamentos de Contabilidade e Atuária, Faculdade de Economia, Administração e Contabilidade da Universidade de São Paulo.

APIMEC NACIONAL. Reunião Apimec Companhia de Ferro Ligas da Bahia: 
apresentação de demonstrações contábeis de 2010. São Paulo: 07/04/2010.

AZEVEDO, Osmar Reis. Comentários às novas regras contábeis brasileiras. 3. ed. São Paulo: IOB, 2009.

BANCO CENTRAL DO BRASIL. Circular n ${ }^{\circ}$ 3068. Estabelece critérios para registro e avaliação contábil de títulos e valores mobiliários. 08 de Novembro de 2001.

BARBETTA, Pedro Alberto. Estatística aplicada às ciências sociais.7.ed. Florianópolis: Ed. da UFSC, 2007.

BARROS, Claudio Marcelo Edwards; ESPEJO, Márcia Maria dos Santos Bortolocci; FREITAS, Aline Carneiro. A relevância da informação contábil no mercado acionário brasileiro: uma análise empírica de companhias listadas na BM\&FBovespa antes e após a promulgação da Lei 11.638/07. Revista Ambiente Contábil. v. 5, n. 1, p. 241-262, jan/jun. 2013.

BARTH, Mary E.; LANDSMAN, Wayne R.; LANG, Mark H. International Accounting Standards and Accounting Quality. Journal of Accounting Research. v.46, n.3, p. 467498, 2008.

BARTH, Mary E.; LANDSMAN, Wayne R.; LANG, Mark H.; WILLIAMS, Christopher D. Are IFRS-based and US GAAP-based accounting amounts comparable? Journal of Accounting and Economics. v.54, issue 1, p.68-93, August 2012.

BATISTELLA, Flávio Donizete. Reavaliação de ativos e correção monetária integral no Brasil: um estudo de value relevance. 2011. Tese (Doutorado em Ciências Contábeis) Faculdade de Economia, Administração e Contabilidade da Universidade de São Paulo FEA/USP. São Paulo.

BENETTI, Cristiane. Stakeholders perception of IFRS utility. Tese (Doutorado em Ciências Contábeis) - Programa de Pós-Graduação em Ciências Contábeis, Departamentos de Contabilidade e Atuária, Faculdade de Economia, Administração e Contabilidade da Universidade de São Paulo, e Department of Management Science of the University of Grenoble.

BM\&FBovespa. Estatísticas - número de empresas. Edição n. 22, Ano 3. Dezembro de 2010. Disponível em<http://www.bmfbovespa.com.br/empresas/boletim-edicao-22estatisticas-numero-de-empresas.asp> . Acesso em 08 de Agosto de 2012.

Empresas listadas. Disponível em<http://www.bmfbovespa.com.br/ciaslistadas/empresas-listadas/BuscaEmpresaListada.aspx?Idioma=pt-br > . Acesso em 08 de Junho de 2012a.

Listagens recentes. Disponível em<http://www.bmfbovespa.com.br/ciaslistadas/consultas/ipos-recentes/ipos-recentes.aspx?idioma=pt-br $>$. Acesso em 22 de 
Agosto de 2012b.

BRAGA, Hugo Rocha; ALMEIDA, Marcelo Cavalcanti. Mudanças contábeis na lei societária: lei no 11.638, de 28/12/2007. São Paulo: Atlas, 2008.

BRASIL. Lei $\mathrm{n}^{\circ}$ 6.404, de 15 de dezembro de 1976. Dispõe sobre as Sociedades por Ações.

. Lei $n^{\circ}$ 9.249, de 26 de Dezembro de 1995. Altera a legislação do imposto de renda das pessoas jurídicas, bem como da contribuição social sobre o lucro líquido, e dá outras providências.

. Lei $\mathrm{n}^{\circ} 10.303$, de 31 de Outubro de 2001. Altera e acrescenta dispositivos na Lei no 6.404, de 15 de dezembro de 1976, que dispõe sobre as Sociedades por Ações, e na Lei no 6.385, de 7 de dezembro de 1976, que dispõe sobre o mercado de valores mobiliários e cria a Comissão de Valores Mobiliários.

. Lei $\mathrm{n}^{\circ} 11.638$, de 28 de Dezembro de 2007. Altera e revoga dispositivos da Lei no 6.404, de 15 de dezembro de 1976, e da Lei no 6.385, de 7 de dezembro de 1976, e estende às sociedades de grande porte disposições relativas à elaboração e divulgação de demonstrações financeiras.

- Lei $\mathrm{n}^{\circ} 11.941$, de 27 de Maio de 2009. Altera a legislação tributária federal relativa ao parcelamento ordinário de débitos tributários; concede remissão nos casos em que especifica; institui regime tributário de transição, alterando o Decreto no 70.235, de 6 de março de 1972, as Leis nos 8.212, de 24 de julho de 1991, 8.213, de 24 de julho de 1991, 8.218, de 29 de agosto de 1991, 9.249, de 26 de dezembro de 1995, 9.430, de 27 de dezembro de 1996, 9.469, de 10 de julho de 1997, 9.532, de 10 de dezembro de 1997, 10.426 , de 24 de abril de 2002, 10.480, de 2 de julho de 2002, 10.522, de 19 de julho de $2002,10.887$, de 18 de junho de 2004, e 6.404, de 15 de dezembro de 1976, o DecretoLei no 1.598, de 26 de dezembro de 1977, e as Leis nos 8.981, de 20 de janeiro de 1995, 10.925 , de 23 de julho de 2004, 10.637, de 30 de dezembro de 2002, 10.833, de 29 de dezembro de 2003, 11.116, de 18 de maio de 2005, 11.732, de 30 de junho de 2008, 10.260, de 12 de julho de 2001, 9.873, de 23 de novembro de 1999, 11.171, de 2 de setembro de 2005, 11.345, de 14 de setembro de 2006; prorroga a vigência da Lei no 8.989, de 24 de fevereiro de 1995; revoga dispositivos das Leis nos 8.383, de 30 de dezembro de 1991, e 8.620, de 5 de janeiro de 1993, do Decreto-Lei no 73, de 21 de novembro de 1966, das Leis nos 10.190, de 14 de fevereiro de 2001, 9.718, de 27 de novembro de 1998, e 6.938, de 31 de agosto de 1981, 9.964, de 10 de abril de 2000, e, a partir da instalação do Conselho Administrativo de Recursos Fiscais, os Decretos nos 83.304, de 28 de março de 1979, e 89.892, de 2 de julho de 1984, e o art. 112 da Lei no 11.196, de 21 de novembro de 2005; e dá outras providências.

BRITO, Giovani Antonio Silva; CORRAR, Luiz João; BATISTELLA, Flávio Donizete. Fatores determinantes da estrutura de capital das maiores empresas que atuam no Brasil. Revista Contabilidade \& Finanças, v.18, n. 43, p. 9-19, janeiro-abril 2007.

BRITO, Giovani Antonio Silva. Conservadorismo contábil e o custo do crédito 
bancário no Brasil. 2010. Tese (Doutorado em Ciências Contábeis) Faculdade de Economia, Administração e Contabilidade da Universidade de São Paulo - FEA/USP. São Paulo.

BUSSAB, Wilton de O., MORETTIN, Pedro A. Estatística básica.5.ed. São Paulo: Saraiva, 2002.

CAIRNS, David; MASSOUDI, Dianne; TAPLIN, Ross; TARCA, Ann. IFRS fair value measurement and accounting policy choice in the United Kingdom and Australia. The British Accounting Review. v.43, issue 1, p. 1-21, March 2011.

CALIJURI, Mônica Sionara Schpallir. As novas normas de convergência contábeis e seus reflexos para os contribuintes, In Mosquera, Roberto Quiroga; Lopes, Alexsandro Broedel (coord); Controvérsias jurídico-contábeis (aproximações e distanciamentos), $\mathbf{2}^{\mathbf{0}}$. volume. São Paulo: Dialética, 2011.

CAMBRIA, Marcelo. O impacto da primeira adoção das normas IFRS nas empresas européias químicas e de mineração: pesquisa descritiva. 2008. Dissertação (Mestrado em Ciências Contábeis) - Programa de Pós-Graduação em Ciências Contábeis, Departamentos de Contabilidade e Atuária, Faculdade de Economia, Administração e Contabilidade da Universidade de São Paulo.

CÂNDIDO, Marçal Serafim. Estrutura de capital e assimetria de informação: efeitos da governança corporativa. 2010. Dissertação (Mestrado em Controladoria e Contabilidade) - Programa de Pós-Graduação em Ciências Contábeis, Departamentos de Contabilidade e Atuária, Faculdade de Economia, Administração e Contabilidade de Ribeirão Preto da Universidade de São Paulo.

CARVALHO, Nelson. Essência $\mathrm{x}$ forma na contabilidade, In Mosquera, Roberto Quiroga; Lopes, Alexsandro Broedel (coord); Controvérsias jurídico-contábeis aproximações e distanciamentos).São Paulo: Dialética, 2010.

CHOI, Frederick. D. S.; MUELLER, Gerhard G. International Accounting. 2. ed. New Jersey: Prentice-Hall, 1992.

CHOW, Y.C. The doctrine of proprietorship. In: The Accounting Review, vol XVII, p. 157-163, April, 1942.

COASE, R.H. The nature of the firm. Economica, Volume 4, issue 16, p.386-405, November $1937 . \quad$ Disponível em <http://onlinelibrary.wiley.com.ez67.periodicos.capes.gov.br/doi/10.1111/j.1468-

0335.1937.tb00002.x/abstract>. Acesso em 05 de Junho de 2012.

COMISSÃO DE VALORES MOBILIÁRIOS. Instrução CVM n ${ }^{\circ}$ 10, de 14 de Fevereiro de 1980. Dispõe sobre a aquisição por companhias abertas de ações de sua própria emissão, para cancelamento ou permanência em tesouraria, e respectiva 
alienação.

. Instrução CVM no 268, de 13 de Novembro de 1997. Altera o limite previsto no art. $3^{\circ}$ da Instrução CVM n ${ }^{\circ} 10$, de 14 de fevereiro de 1980.

. Deliberação CVM no 488, de 03 de Outubro de 2005. Aprova o Pronunciamento do IBRACON NPC n 27 sobre Demonstrações Contábeis - Apresentação e Divulgações.

- Deliberação CVM no 676 de 13 de Dezembro de 2011. Aprova o Pronunciamento Técnico CPC 26(R1) do Comitê de Pronunciamentos Contábeis, que trata da Apresentação das Demonstrações Contábeis.

COMITE DE PRONUNCIAMENTOS CONTABEIS. Pronunciamento conceitual básico, de 11 de Janeiro de 2008a.

Pronunciamento técnico CPC 13 - adoção inicial da lei ${ }^{\circ} 11.638 / 07$ e da medida provisória $\mathrm{n}^{\circ}$ 449/08, de 05 de Dezembro de 2008b.

Orientação OCPC 02 - Esclarecimentos sobre as demonstrações contábeis de 2008, de 30 de Janeiro de 2009a.

. Pronunciamento técnico CPC 26 - apresentação das demonstrações contábeis, de 17 de Julho de 2009b.

- Interpretação técnica ICPC 08 - contabilização da proposta de pagamento de dividendos, de 04 de Setembro de 2009c.

- Pronunciamento técnico CPC 36 - Demonstrações consolidadas, de 06 de Novembro de 2009d.

. Pronunciamento técnico CPC 24 - Evento subsequente, de 17 de Julho de 2009e.

. Pronunciamento técnico CPC 25 - Provisões, passivos contingentes e ativos contingentes, de 26 de Junho de 2009f.

- Pronunciamento técnico CPC 08 (R1) - Custos de transação e prêmios na emissão de títulos e valores mobiliários, de 03 de Dezembro de 2010a.

. Pronunciamento técnico CPC 10 (R1) - Pagamento baseado em ações, de 03 de Dezembro de 2010b.

- Pronunciamento técnico CPC 26 (R1) - apresentação das demonstrações contábeis, de 02 de Dezembro de 2011a. 
. Pronunciamento conceitual básico (R1), de 2 de Dezembro de 2011b.

. Pronunciamento técnico CPC 46 - mensuração do valor justo, de 07 de Dezembro de 2012.

CONSELHO FEDERAL DE CONTABILIDADE. Resolução CFC nº 758/93, de 29 de Dezembro de 1993.

. Resolução CFC nº 937/02, de 24 de Maio de 2002.

. Resolução CFC n 1240/09, de 27 de Novembro de 2009.

COSTA, Thiago de Abreu; ALMEIDA, Sidmar Roberto Vieira; SILVA, Adolfo Henrique Coutinho e. Análise dos impactos das normas internacionais de contabilidade sobre o lucro líquido e o patrimônio líquido das empresas de extração e processamento de recursos naturais. In: II Congresso Nacional de Administração e Ciências Contábeis AdCont 2011, Rio de Janeiro. Anais... Rio de Janeiro: UFRJ, 2011. Link: <http://www.facc.ufrj.br/ocs/index.php/adcont/adcont2011/paper/viewFile/396/61>. Acessoem 05/12/2011.

CRONBACH, Lee J. Coefficient alpha and the internal structure of tests. Psychometrika, vol. 16, no.8, September 1951.

DEFOND, Mark; HU, Xuesong; HUNG, Mingyi; LI, Siqi. The impact of mandatory IFRS adoption on foreign mutual fund ownership: the role of comparability. Journal of Accounting and Economics. v.51, issue 3, p.240-258, April 2011.

DEMERJIAN, Peter R. Accounting standards and debt covenants: has the "balance sheet approach" led to a decline in the use of balance sheet covenants? Journal of Accounting \& Economics, v.52, issues 2-3, p. 178-202, November 2011.

DEMO, Pedro. Introdução à metodologia da ciência.2.ed. 18. reimpr. São Paulo: Atlas, 2010.

DEMO, Pedro. Praticar ciência: metodologias do conhecimento científico.2.ed. 18. reimpr. São Paulo: Saraiva, 2011.

ENCARNAÇÃO, Carina Fabíola Gonçalves da. Indicadores econômico-financeiros: os impactos da alteração normativa em Portugal. 2009. Dissertação (Mestrado em Contabilidade) - Lisboa: ISCTE. Disponível em <http://hdl.handle.net/10071/1851>. Acesso em 12/03/2013.

ENERGISA. Demonstrações contábeis 2011. Disponível em: <http://www.investidores.grupoenergisa.com.br/energisa/web/arquivos/Dfs\%202011\%20 Energisa.pdf $>$. Acesso em 31 de maio de 2012. 
ERNST \& YOUNG; FIPECAFI. Manual de normas internacionais de contabilidade: IFRS versus normas brasileiras. 2. ed. São Paulo: Atlas, 2010.

FÁVERO, Luiz Paulo Lopes et al. Análise de dados: modelagem multivariada para tomada de decisões. Rio de Janeiro: Elsevier, 2009.

FINANCIAL ACCOUNTING STANDARD BOARD. Statement of Financial Accounting Concepts No.1. Novembro de 1978. Disponível em $<$ http://www.fasb.org/cs/BlobServer?blobcol=urldata\&blobtable=MungoBlobs\&blobkey $=$ id\&blobwhere $=1175820899258 \&$ blobheader=application $\% 2 F p d f>. \quad$ Acesso em $31 / 10 / 2011$.

FORMIGONI, Henrique. A influência dos incentivos fiscais sobre a estrutura de capital e a rentabilidade das companhias abertas brasileiras não financeiras. São Paulo, 2008. Tese (Doutorado) - Programa de Pós-Graduação em Ciências Contábeis, Departamento de Contabilidade e Atuária, Faculdade de Economia, Administração e Contabilidade da Universidade de São Paulo.

FORTE, Denis. Estudo sobre a estrutura de capital das empresas brasileiras no período pós Plano Real (1995-2005). São Paulo, 2007. Tese (Doutorado) - Programa de Pós-Graduação em Administração de Empresas da Universidade Presbiteriana Mackenzie.

FURUTA, Fernanda; BISPO, Jorge de Souza; VIEIRA, Patricia dos Santos. Convergência internacional: nível de disclosure e impactos de inovações legais sobre o patrimônio líquido e o resultado das grandes empresas instaladas no Brasil. In: X Congresso USP de Controladoria e Contabilidade, 2010, São Paulo. Anais... São Paulo: USP, 2010. Link: <http://www.congressousp.fipecafi.org/artigos102010/389.pdf>. Acesso em 05/12/2011.

GALDI, Fernando Caio. Estratégias de investimento em ações baseadas na análise de demonstrações contábeis: é possível prever o sucesso? 2008. Tese (Doutorado em Ciências Contábeis) - Programa de Pós-Graduação em Ciências Contábeis, Departamentos de Contabilidade e Atuária, Faculdade de Economia, Administração e Contabilidade da Universidade de São Paulo.

GERON, Cecília Moraes Santostaso. Evolução das práticas contábeis no Brasil no últimos trinta anos: da lei $n^{\mathbf{0}} \mathbf{6 . 4 0 4 / 7 6}$ à lei $\mathbf{n}^{\mathbf{0}}$ 11.638/07. 2008. Dissertação (Mestrado em Ciências Contábeis) - Programa de Pós-Graduação em Ciências Contábeis, Departamentos de Contabilidade e Atuária, Faculdade de Economia, Administração e Contabilidade da Universidade de São Paulo.

GIL, Antônio Carlos. Métodos e técnicas de pesquisa social. 5. ed. São Paulo: Atlas, 1999.

GIRIOLI, Lumila Souza. Análise do uso de medidas de desempenho de empresas presentes na pesquisa em contabilidade no Brasil. 2010. Dissertação (Mestrado em 
Ciências Contábeis) - Programa de Pós-Graduação em Ciências Contábeis, Departamentos de Contabilidade e Atuária, Faculdade de Economia, Administração e Contabilidade de Ribeirão Preto da Universidade de São Paulo.

GORDON, Isabel; GALLERY, Natalie. Assessing financial reporting comparability across institutional settings: the case of pension accounting. The British Accounting Review. v.44, issue 1, p.11-20, March 2012.

GREGÓRIO, Jaime. Análise comparativa da rentabilidade do setor bancário privado atuante no Brasil no período de 1997 a 2004.2005. Dissertação (Mestrado em Controladoria e Contabilidade) - Programa de Pós-Graduação em Ciências Contábeis, Departamentos de Contabilidade e Atuária, Faculdade de Economia, Administração e Contabilidade da Universidade de São Paulo.

GUIMARÃES, Carla Caricatti. Impacto do ISE no valor da empresa obtido pelo modelo Ohlson. 2010. Dissertação (Mestrado em Ciências Contábeis) - Fundação Escola de Comércio Álvares Penteado - FECAP.

HAIR, J.F.; ANDERSON, R.E.; TATHAM, R.L.; BLACK, W.C. Análise multivariada de dados; tradução de Adonai Sant'Anna e Anselmo Chaves Neto. 5. ed. Porto Alegre: Bookman, 2005.

HARRIS, Milton; RAVIV, Artur. The theory of capital structure. The Journal of Finance, v. 46, n.1, p. 297-355, March 1991.

HENDRIKSEN, Eldon S., VAN BREDA, Michael F. Teoria da contabilidade; tradução de Antonio Zoratto Sanvicente. São Paulo: Atlas, 1999.

HILL, Manuela Magalhães; HILL, Andrew. Investigação por questionário. 2. ed. 3. reimpr. Lisboa: Sílabo. 2008.

HUSBAND, George R. The corporate-entity fiction and accounting theory. In: The Accounting Review, vol XIII, n.3, p. 241-253, setembro de 1938.

IGNACIO, Sergio da Silva. Avaliação da conexão entre as normas e práticas contábeis e fiscais no Brasil. 2010. Dissertação (Mestrado em Controladoria e Contabilidade) - Programa de Pós-Graduação em Ciências Contábeis, Departamentos de Contabilidade e Atuária, Faculdade de Economia, Administração e Contabilidade de Ribeirão Preto da Universidade de São Paulo.

IFRS FOUNDATION. The conceptual framework for financial reporting. Setembro de 2010. Disponível em <http://eifrs.iasb.org/eifrs/bnstandards/en/framework.pdf>. Acesso em 31/10/2011.

- January 2012 perspectives. Disponível em

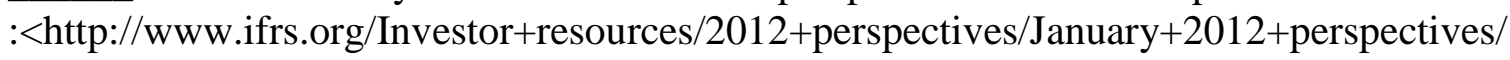


Performance+Reporting.htm>. Acesso em 02 de Fevereiro de 2012a.
$\overline{\text { December }}$
http://www.ifrs.org/Meetings/MeetingDocs/IASB/2012/December/3to3C-Concept-
1212.zip>. Acesso em 16 de Abril de 2013.

Conceptual framework: liability/equity. Agenda paper 3B.

IUDÍCIBUS, Sérgio de; LOPES, Alexsandro Broedel. Teoria avançada da contabilidade. São Paulo: Atlas, 2004.

IUDÍCIBUS, Sérgio de. Teoria da contabilidade. 9. ed. 2. reimpr. São Paulo: Atlas, 2009.

IUDÍCIBUS, Sérgio de; MARTINS, Eliseu; GELBCKE, Ernesto Rubens; SANTOS, Ariovaldo dos. Manual de contabilidade societária. São Paulo: Atlas, 2010.

IUDÍCIBUS, Sérgio de. Essência sobre a forma e o valor justo: duas faces da mesma moeda, In Mosquera, Roberto Quiroga; Lopes, Alexsandro Broedel (coord); Controvérsias jurídico-contábeis (aproximações e distanciamentos).São Paulo: Dialética, 2010.

KAM, Vernon. Accounting theory. California: John Wiley \& Sons, 1986.

KARAMANOU, Irene; NISHIOTIS, George P.. Disclosure and the Cost of Capital: Evidence from the Market's Reaction to Firm Voluntary Adoption of IAS. Journal of Business Finance \& Accounting. v. 37 , n. 7 e 8, p. 793 - 821,set./out. 2009. Disponível em

$<$ http://link.periodicos.capes.gov.br.ez67.periodicos.capes.gov.br/sfxlcl3?url_ver=Z39.88 -2004\&url_ctx_fmt=infofi/fmt:kev:mtx:ctx\&ctx_enc=info:ofi/enc:UTF-

$8 \&$ ctx_ver=Z39.88-

2004\&rfr_id=info:sid/sfxit.com:azlist\&sfx.ignore_date_threshold=1\&rft.object_id=9549

21388928\&svc.fulltext=yes>. Acesso em 05 de Maio de 2012.

KLANN, Roberto Carlos; SOUZA, José Carlos de; BEUREN, Ilse Maria. O impacto do não reconhecimento da inflação nas demonstrações contábeis na distribuição de dividendos. Revista de Educação e Pesquisa em Contabilidade, Brasília, v.1, n.1, art.5, p. 59-78, jan/abr. 2007.

KMETEUK FILHO, Osmir. Pesquisa e análise estatística. Rio de Janeiro: Fundo de Cultura, 2005.

LAGE, Antonio Carlos; LONGO, Cláudio Gonçalo; WEFFORT, Elionor Farah Jreige. Estrutura conceitual para a elaboração e apresentação das demonstrações financeiras, In Ernst \& Young; Fipecafi; IFRS versus normas brasileiras.São Paulo: Atlas, 2010.

LARSON, Robert K.; STREET, Donna L. Convergence with IFRS in an expanding Europe: progress and obstacles identified by large accounting firms' survey. Journal of 
International Accounting, Auditing and Taxation, v. 13, p. 89-119, 2004.

LEAL, Ricardo Pereira Câmara; SAITO, Richard. Finanças Corporativas no Brasil. RAE Eletrônica, v.2, n. 2, p. 1-15, jul.-dez., 2003. Disponível em :<http://dx.doi.org.ez67.periodicos.capes.gov.br/10.1590/S1676-56482003000200005> . Acesso em 15 de Maio de 2012.

LEMES, Sirlei; CARVALHO, Luiz Nelson Guedes de. Comparabilidade entre resultado em BR GAAP e U.S.GAPP: evidências das companhias brasileiras listadas nas bolsas norte-americanas. Revista de Contabilidade e Finanças, São Paulo, v.20, n. 50, p. 25 45, maio/agosto 2009.

LIMA, Gerlando Augusto Sampaio Franco de. Nível de evidenciação x custo da dívida das empresas brasileiras. Revista de Contabilidade e Finanças, São Paulo, v.20, n. 49, p. 95-108, janeiro/abril 2009.

LIMA, João Batista Nast de. A relevância da informação contábil e o processo de convergência para as normas IFRS no Brasil. 2010. Tese (Doutoramento) - Faculdade de Economia, Administração e Contabilidade, Universidade de São Paulo, São Paulo.

LITTLETON, Ananias Charles; ZIMMERMAN, Vernon Kenneth. Accounting theory: continuity and change. EnglewoodCiffs: Prentice-Hall, 1962.

LOPES, Alexsandro Broedel. A teoria dos contratos, governança corporativa e contabilidade. In: IUDÍCIBUS, Sérgio de; LOPES, Alexsandro Broedel (Coord). Teoria avançada da contabilidade. São Paulo: Atlas, 2004.

LOPES, Alexsandro Broedel. Financial accounting in Brazil: an emprirical examination. Latin American Business Review, 6, p.45-68, 2005.

; MARTINS, Eliseu. Teoria da contabilidade: uma nova abordagem. 2. reimpr. São Paulo: Atlas, 2007.

LOPES, Jorge Eduardo de Medeiros; RIBEIRO, Ricardo Biali; CAVALVANTE, Paulo Roberto Nóbrega. A informação contábil à luz da teoria da comunicação. Revista Ambiente Contábil. v. 1, n. 2, p. 22-37, jul./dez. 2009.

LOPES, Alexsandro Broedel; MOSQUERA, Roberto Quiroga. O direito contábil fundamentos conceituais, aspectos da experiência brasileira e implicações, In Mosquera, Roberto Quiroga; Lopes, Alexsandro Broedel (coord); Controvérsias jurídico-contábeis (aproximações e distanciamentos). São Paulo: Dialética, 2010.

LYRA, Ricardo Luiz Wust Corrêa de. Análise hierárquica dos indicadores contábeis sob a óptica do desempenho empresarial. 2008. Tese (Doutorado em Controladoria e Contabilidade) - Programa de Pós-Graduação em Ciências Contábeis, Departamentos de Contabilidade e Atuária, Faculdade de Economia, Administração e Contabilidade da 
Universidade de São Paulo.

MACEDO, Marcelo Alvaro da Silva; ARAÚJO, Marcelo Bicalho Viturino de; BRAGA, Josué Pires. Impacto do processo de convergência às normas internacionais de contabilidade na relevância das informações contábeis. REPeC- Revista de Educação e Pesquisa em Contabilidade, Brasília, v.6, n. 4, art. 2, p. 367-382, out-dez 2012.

MAROCO, João. Análise estatística: com utilização do SPSS. 3.ed. Lisboa: Sílabo, 2007.

MARTINS, Gilberto de Andrade. Sobre confiabilidade e validade. RBGN, São Paulo, vol. 8, n.20, p.1-12, jan./abr. 2006.

MARTINS, Gilberto de Andrade. Estatística geral e aplicada.3.ed. 3 reimpr. São Paulo: Atlas, 2008.

MARTINS, Gilberto de Andrade; TEÓPHILO, Carlos Renato. Metodologia da investigação científica para ciências sociais aplicadas.2.ed. São Paulo: Atlas, 2009.

MARTINS, Eliseu. Ensaio sobre a evolução do uso e das características do valor justo, InMosquera, Roberto Quiroga; Lopes, Alexsandro Broedel (coord); Controvérsias jurídico-contábeis (aproximações e distanciamentos). São Paulo: Dialética, 2010.

MARTINS, Orleans Silva; PAULO, Edilson. Reflexo da adoção das IFRS na análise de desempenho das companhias de capital aberto no Brasil. Revista de Contabilidade e Organizações. v. 4, n. 9, p. 30-54, mai./ago. 2010.

MARTINS, Eliseu; DINIZ, Josedilton Alves; MIRANDA, Gilberto José. Análise avançada das demonstrações contábeis: uma abordagem crítica. São Paulo: Atlas, 2012.

MELO, Sheila de; MARTINS, Eliseu; NAGAI, Cristiane; AMARAL, Juliana Ventura. Catorze anos de demonstrações contábeis incompletas: um estudo em empresas de energia elétrica. In: $11^{\circ}$ Congresso USP de Controladoria e Contabilidade, Julho de 2011, São Paulo. Anais... São Paulo: USP, 2011. Disponível em :<http://www.congressousp.fipecafi.org/artigos112011/477.pdf>. Acesso em 19/03/2013.

MIRANDA, Vanessa Lopes. Impacto da adoção das IFRS (International Financial Reporting Standards) em indicadores econômico-financeiros de bancos de alguns países da união européia. 2008. Dissertação (Mestrado em Ciências Contábeis) Programa de Pós-Graduação em Ciências Contábeis, Departamentos de Contabilidade e Atuária, Faculdade de Economia, Administração e Contabilidade da Universidade de São Paulo.

MORAIS, Ana Isabel; CURTO, José Dias. Accounting Quality and the Adoption of IASB Standards. Revista de Contabilidade \& Finanças. São Paulo, v. 19, n. 48, p. 103 
- 111, setembro/dezembro 2008.

MOSQUERA, Roberto Quiroga; FREITAS, Rodrigo de. Aspectos polêmicos do ágio na aquisição de investimento: (i) rentabilidade futura e (ii) ágio interno, In Mosquera, Roberto Quiroga; Lopes, Alexsandro Broedel (coord); Controvérsias jurídico-contábeis (aproximações e distanciamentos), $2^{\circ}$. volume. São Paulo: Dialética, 2011.

MYERS, Stewart C. The capital structure puzzle. The Journal of Finance. Chicago, v. 39, n. 3, p. 575-592, jul. 1984.

Capital Structure. The Journal of Economic Perspectives. Nashville, v.15, n.2, p. 81-102, spring 2001.

NAKAMURA, Wilson Toshiro.; MARTIN, Diogenes Manoel Leiva; FORTE, Denis; CARVALHO FILHO, Antonio Francisco; COSTA, André Castilho Ferreira da; AMARAL, Alexandre Cintra do. Determinantes de estrutura de capital no mercado brasileiro: análise de regressão com painel de dados no período 1999-2003. Revista Contabilidade \& Finanças, v. 18, n. 44, p. 72-85, maio-agosto 2007.

NASCIMENTO, Auster Moreira; REGINATO, Luciane. Divulgação da informação contábil, governança corporativa e controle organizacional: uma relação necessária. Revista Universo Contábil. v. 4, n. 3, p. 25-47, jul./set. 2008.

NETO, João Estevão Barbosa; DIAS, Warley de Oliveira; PINHEIRO, Laura Edith Taboada. Impacto da convergência para as IFRS na análise financeira: um estudo em empresas brasileiras de capital aberto. Revista Contabilidade Vista \& Revista, Belo Horizonte, v.20, n. 49, p. 131-153, out/dez 2009.

NUNES, Tânia Cristina Silva. Indicadores contábeis como medidas de risco e retorno diferenciados de empresas sustentáveis: um estudo no mercado brasileiro. 2010. Dissertação (Mestrado em Controladoria e Contabilidade) - Programa de Pós-Graduação em Ciências Contábeis, Departamentos de Contabilidade e Atuária, Faculdade de Economia, Administração e Contabilidade da Universidade de São Paulo.

OLIVEIRA, Daniel Diniz. A homogeneidade da rentabilidade bancária em relação a tamanho, origem de capital e operações de crédito. 2008. Dissertação (Mestrado em Ciências Contábeis) - Programa de Pós-Graduação em Ciências Contábeis, Departamentos de Contabilidade e Atuária, Faculdade de Economia, Administração e Contabilidade da Universidade de São Paulo.

OLIVEIRA, Vanessa Herculano de. Operações com títulos e valores mobiliários: impactos sobre os principais indicadores econômico-financeiros de bancos atuantes no Brasil. 2011. Dissertação (Mestrado em Ciências Contábeis) - Programa de PósGraduação em Ciências Contábeis, Departamentos de Contabilidade e Atuária, Faculdade de Economia, Administração e Contabilidade da Universidade de São Paulo.

PALEPU, Krishna. G.; HEALY, Paul M.; BERNARD, Victor L. Business analysis 
\&valuation: using financial statements. $3^{\text {rd }}$. Ed. Ohio: Thomson South-Western, 2004.

PEROBELLI, Fernanda Finotti Cordeiro; FAMÁ, Rubens. Determinantes da estrutura de capital: aplicação a empresas de capital aberto brasileiras. Revista de Administração da Universidade de São Paulo, São Paulo, v. 37, n. 3, p. 33-46, julho-setembro 2002.

PRICEWATERHOUSECOOPERS. Manual de contabilidade IFRS/CPC: demonstrações financeiras consolidadas (tradução). São Paulo: Saint Paul, 2011.

RESENDE, Leandro Lima; CUNHA, Jacqueline Veneroso Alves da; NETO, João Estevão Barbosa, DIAS, Warley de Oliveira. Plataforma teórica das dissertações em contabilidade: onde está a teoria? In: XIV Semead - Seminários em Administração, Outubro de 2011, São Paulo. Anais... São Paulo: USP, 2011. Link: <http://www.ead.fea.usp.br/semead/14semead/resultado/trabalhosPDF/477.pdf>. Acesso em 05/06/2012.

REZENDE, Amaury José; GUERREIRO, Reinaldo; DALMÁCIO, Flávia Zóboli. Uma análise do processo de desinstitucionalização de práticas contábeis de correção monetária em empresas brasileiras. Revista de Contabilidade e Finanças, São Paulo, v.23, n. 58, p. 33-51, jan/fev/mar/abr 2012.

SÁ, Fernanda Franco de; MALAQUIAS, Rodrigo Fernandes. Análise da percepção dis discentes do curso de graduação em ciências contábeis sobre expressões de incerteza contidas nos pronunciamentos emitidos pelo Comitê de Pronunciamentos Contábeis. Revista de Contabilidade e Organizações, Ribeirão Preto, v.6, n. 14, p. 78-105, jan-abr 2012.

SANTOS, Ariovaldo dos. Ajuste a valor presente, In Mosquera, Roberto Quiroga; Lopes, Alexsandro Broedel (coord); Controvérsias jurídico-contábeis (aproximações e distanciamentos), $3^{\circ}$. volume. São Paulo: Dialética, 2012a.

SANTOS, Ariovaldo dos. Correção monetária, In Lopes, Alexsandro Broedel (coord); Contabilidade e finanças no Brasil: estudos em homenagem ao professor Eliseu Martins. São Paulo: Atlas, 2012b.

SCHVIRK, Eliandro. A reavaliação de ativos e seus impactos na análise das demonstrações contábeis no Brasil. 2006. Dissertação (Mestrado em Ciências Contábeis) - Programa de Pós-Graduação em Ciências Contábeis, Departamentos de Contabilidade e Atuária, Faculdade de Economia, Administração e Contabilidade da Universidade de São Paulo.

SCHMIDT, Paulo; SANTOS, José Luiz dos. História da contabilidade: foco na evolução das escolas do pensamento contábil. São Paulo: Atlas, 2008.

SEVERINO, Antônio Joaquim. Metodologia do trabalho científico. São Paulo: Cortez, 2002. 
SILVA, Adolfo Henrique Coutinho e. Escolha de práticas contábeis no Brasil: uma análise sob a ótica da hipótese dos covenants contratuais. 2008. Tese (Doutorado em Ciências Contábeis) - Programa de Pós-Graduação em Ciências Contábeis, Departamentos de Contabilidade e Atuária, Faculdade de Economia, Administração e Contabilidade da Universidade de São Paulo.

SILVA, Pedro Cláudio da; WEFFORT, Elionor Farah Jreige; PETERS, Marcos Reinaldo Severino; CIA, Joanília Neide de Sales. Impacto na adoção das IFRS nas empresas brasileiras de saneamento: a percepção dos profissionais do setor. Revista Contabilidade Vista \& Revista. v. 21, n. 2, p. 69-94, abr./jun. 2010.

SILVA, Ricardo Luiz Menezes da; LOPES, Alexsandro Broedel. Demonstrações contábeis no Brasil após adoção do CPC 13: reação do mercado de ações e consequências econômicas. In: $12^{\circ}$ Congresso USP de Controladoria e Contabilidade, Julho de 2012, São Paulo. Anais... São Paulo: USP, 2012. Link: <http://www.congressousp.fipecafi.org/artigos122012/324.pdf>. Acesso em 26/02/2013.

SILVA, Ricardo Luiz Menezes da; SILVA, Elizabeth Betini Gomes da; NARDI, Paula Carolina Ciampaglia. A relevância do dividendo adicional proposto. In: $10^{\circ}$ Congresso USP de Iniciação Científica em Contabilidade, Julho de 2013, São Paulo. Anais... São Paulo: USP, 2012. Link: 〈http://www.congressousp.fipecafi.org/artigos132013/326.pdf>. Acesso em 07/05/2013.

SILVA, Ricardo Luiz Menezes da. Adoção completa das IFRS no Brasil: qualidade das demonstrações contábeis e o custo do capital próprio. 2013. Tese (Doutorado em Controladoria e Contabilidade) - Programa de Pós-Graduação em Ciências Contábeis, Departamentos de Contabilidade e Atuária, Faculdade de Economia, Administração e Contabilidade da Universidade de São Paulo.

SILVEIRA, Alexandre di Miceli da; PEROBELLI, Fernanda Finotti Cordeiro; BARROS, Lucas Ayres Barreira de Campos. Governança Corporativa e os determinantes da estrutura de capital: evidências empíricas no Brasil. Revista de Administração Contemporânea. v. 12, n. 3, p. 763-788, jul./set. 2008.

SLOAN, Richard G. Financial accounting and corporate governance: a discussion. Journal of Accounting and Economics, v.32, p.335-347, Dezembro de 2001. Disponível em <http://dx.doi.org.ez67.periodicos.capes.gov.br/10.1016/S01654101(01)00039-8>. Acesso em 20 de Abril de 2012.

SOARES, Maria Aparecida. Análise de indicadores para avaliação de desempenho econômico-financeiro de operadoras de planos de saúde brasileiras: uma aplicação de análise fatorial. 2006. Dissertação (Mestrado em Ciências Contábeis) - Programa de Pós-Graduação em Ciências Contábeis, Departamentos de Contabilidade e Atuária, Faculdade de Economia, Administração e Contabilidade da Universidade de São Paulo.

SOUZA, Júlia Alves; NETO, Alfredo Sarlo; VARGAS, Luiz Henrique Fernandes; DEMONIER, Gladyson Brommonschenkel. Práticas contábeis apresentadas por empresas brasileiras antes e após a adoção das normas internacionais. In: $12^{\circ}$ Congresso 
USP de Controladoria e Contabilidade, Julho de 2012, São Paulo. Anais... São Paulo: USP, 2012. Link: <http://www.congressousp.fipecafi.org/artigos122012/513.pdf>. Acessoem 26/02/2013

STAUBUS, George J. The residual equity point of view in accounting. In: The Accounting Review, vol. XXXIV, n.1, p. 3-13, January, 1959

SUNDER, Shyam. Theory of accounting and control. Ohio: South-Western Publishing, 1997a.

SUNDER, Shyam. Accounting and the firm: a contract theory. Indian Accounting Review v.1, n.1, June 1997b.

SUOJANEN, Waino W. Accounting Theory and the large corporation. In: The Accounting Review, vol. XXIX, n.3, p. 391-398, july, 1954.

SUPERINTENDÊNCIA DE SEGUROS PRIVADOS. Circular $n^{\circ}$ 192. Estabelece critérios para avaliação e registro contábil de títulos e valores mobiliários. 25 de Junho de 2002.

UNIVERSIDADE DE SÃO PAULO - Faculdade de Economia, Administração e Contabilidade - Comissão de Pós Graduação. Manual para formatação e edição de dissertações e teses. São Paulo, 2008. Disponível em <http://www.eac.fea.usp.br/ensino/pos_graduacao/FormatDissertacao.aspx>. Acesso em 20 de Janeiro de 2012.

VASCONCELOS, Luciola Aor; CHAVES, Simone de Mesquita Teixeira; CARVALHO, Flavia Siqueira de; TAVARES, Adilson de Lima; BARBOSA, Glauber de Castro. Inflação e correção monetária de balanços. In: $12^{\circ}$ Congresso USP de Controladoria e Contabilidade, Julho de 2012, São Paulo. Anais... São Paulo: USP, 2012. Link: <http://www.congressousp.fipecafi.org/artigos122012/599.pdf>. Acesso em 26/02/2013.

VERGARA, Sylvia Constant. Projetos e relatórios de pesquisa em administração. 11 . ed. São Paulo: Atlas, 2009.

VIEIRA, Rafael Bezerra. Impactos da implantação parcial dos IFRS no Brasil: efeitos na qualidade das informações contábeis das empresas de capital aberto. 2010. Dissertação (Mestrado em Controladoria e Contabilidade) - Programa de PósGraduação em Ciências Contábeis, Departamentos de Contabilidade e Atuária, Faculdade de Economia, Administração e Contabilidade de Ribeirão Preto da Universidade de São Paulo.

WEFFORT, Elionor Farah Jreige. O Brasil e a harmonização contábil internacional: influências dos sistemas jurídico e educacional, da cultura e do mercado. São Paulo, Atlas, 2005.

ZEGHAL, Daniel; MHEDHBI, Karim. Analyzing the effect of using international 
accounting standards on the development of emerging capital markets. International Journal of Accounting and Information Management. v.20, iss.3, p.220-237, 2012. 


\section{ANEXOS}

Anexo 1 - Fornecimento de dados relativos às companhias abertas em 31/12/2010

Anexo 2 - Listagens recentes de companhias na BM\&FBOVESPA 

Anexo 1 - Fornecimento de dados relativos às companhias abertas em 31/12/2010

\section{Serviço de Atendimento ao Público BM\&FBOVESPA}

SAP BM\&FBOVESPA <sap@bvmf.com.br>

8 de agosto de 2012 16:13

Para: agonzales@usp.br

\section{BM\&FBOVESPA}

A Nova Bolsa

Assunto: Empresas Listadas/Governança Corporativa

Prezado(a) Alexandre Gonzales,

O Serviço de Atendimento ao Público da BM\&FBOVESPA agradece seu contato. Mediante sua solicitação de protocolo 20120890, informamos o abaixo disposto:

Conforme sua solicitação, segue o anexo do protocolo anterior.

Atenciosamente,

*

Serviço de Atendimento ao Público da BM\&FBOVESPA

www bmfbovespa.com, br

(11) 3272-7373

Siga @Info_BMFBOVESPA | Seja fã www.facebook.com/bolsapravoce

Sua opinião é muito importante. Clique aqui para avaliar nosso atendimento.

Deseja responder esse email? Clique aqui.

EMAIL AUTOMÁ TICO - NÃO RESPONDER

Empresas_Listadas_(Bolsa).xIs

$841 \mathrm{~K}$ 

Anexo 2 - Listagens recentes de companhias na BM\&FBovespa

\section{Listagens Recentes}

Confira as empresas que iniciaram a negociação de ações na BM\&FBOVESPA nos últimos anos.

Clique sobre a empresa para ver mais detalhes.

Estatísticas das Aberturas de Capital na BM\&FBOVESPA

\begin{tabular}{|c|c|c|c|c|c|c|}
\hline Ano & Empresa & $\begin{array}{l}\text { Segmento de } \\
\text { listagem }\end{array}$ & $\begin{array}{c}\text { Natureza da } \\
\text { oferta }\end{array}$ & $\begin{array}{l}\text { Volume R\$ } \\
\text { milhões }{ }^{1}\end{array}$ & $\begin{array}{c}\mathbf{N}^{\mathbf{0}} \text { de } \\
\text { corretoras }^{2}\end{array}$ & $\begin{array}{c}\mathbf{N}^{\mathbf{o}} \text { de } \\
\text { investidores }\end{array}$ \\
\hline \multirow{3}{*}{2012} & $\underline{\mathrm{BTG}}$ & Tradicional & Mista & 3.234 & 56 & 6.231 \\
\hline & $\underline{\text { Unicasa }}$ & Novo Mercado & Mista & 370 & 42 & 785 \\
\hline & $\underline{\text { Locamerica }}$ & Novo Mercado & Mista & 273 & 56 & 246 \\
\hline \multirow{11}{*}{2011} & Abril Educa & Nível 2 & Primária & 371 & 58 & 1.429 \\
\hline & Technos & Novo Mercado & Mista & 462 & 61 & 599 \\
\hline & Qualicorp & Novo Mercado & Mista & 1.085 & 63 & 823 \\
\hline & BR Pharma & Novo Mercado & Primária & 414 & 62 & 148 \\
\hline & Magaz Luiza & Novo Mercado & Mista & 805 & 65 & 34.674 \\
\hline & Time For Fun & Novo Mercado & Mista & 469 & 56 & 907 \\
\hline & IMC Holdings & Novo Mercado & Mista & 454 & 55 & 706 \\
\hline & QGEP PART & Novo Mercado & Primária & 1.515 & 59 & 9.057 \\
\hline & Autometal & Novo Mercado & Mista & 454 & 61 & 3.568 \\
\hline & $\underline{\text { SierraBrasil }}$ & Novo Mercado & Primária & 465 & 57 & 3.423 \\
\hline & ArezzoCo & Novo Mercado & Mista & 566 & 63 & 9.177 \\
\hline \multirow{11}{*}{2010} & $\underline{\text { Raia }}$ & Novo Mercado & Mista & 655 & 49 & 6.876 \\
\hline & $\underline{\text { BR Insurance }}$ & Novo Mercado & Mista & 645 & 54 & 75 \\
\hline & HRT Petróleo & Novo Mercado & Mista & 2.481 & 52 & 144 \\
\hline & Renova & Nível 2 & Primária & 161 & 52 & 585 \\
\hline & Júlio Simões & Novo Mercado & Primária & 478 & 62 & 735 \\
\hline & Mills & Novo Mercado & Mista & 686 & 56 & 1.108 \\
\hline & Ecorodovias & Novo Mercado & Mista & 1.368 & 59 & 2.048 \\
\hline & OSX Brasil & Novo Mercado & Primária & 2.450 & 63 & 31 \\
\hline & $\underline{\text { BrPropert }}$ & Novo Mercado & Mista & 934 & 48 & 1.476 \\
\hline & Multiplus & Novo Mercado & Primária & 629 & 61 & 1.191 \\
\hline & Aliansce & Novo Mercado & Mista & 585 & 62 & 1.643 \\
\hline \multirow{6}{*}{2009} & Fleury & Novo Mercado & Primária & 630 & 60 & 4.799 \\
\hline & Direcional & Novo Mercado & Primária & 274 & 58 & 603 \\
\hline & Cetip & Novo Mercado & Secundária & 773 & 65 & 5.173 \\
\hline & $\underline{\text { Santander BR }}$ & Nível 2 & Primária & 13.182 & 72 & 74.933 \\
\hline & Tivit & Novo Mercado & Secundária & 575 & 59 & 5.870 \\
\hline & $\underline{\text { Visanet }}$ & Novo Mercado & Secundária & 8.397 & 53 & 49.533 \\
\hline 2008 & OGX Petroleo & Novo Mercado & Primária & 6.712 & 55 & 1.377 \\
\hline
\end{tabular}




\begin{tabular}{|c|c|c|c|c|c|c|}
\hline Ano & Empresa & $\begin{array}{l}\text { Segmento de } \\
\text { listagem }\end{array}$ & $\begin{array}{c}\text { Natureza da } \\
\text { oferta }\end{array}$ & $\begin{array}{l}\text { Volume R\$ } \\
\text { milhões }{ }^{1}\end{array}$ & $\begin{array}{c}\mathbf{N}^{0} \text { de } \\
\text { corretoras }^{2}\end{array}$ & $\begin{array}{c}\mathbf{N}^{0} \text { de } \\
\text { investidores }\end{array}$ \\
\hline & $\underline{\text { Le Lis Blanc }}$ & Novo Mercado & Primária & 150 & 63 & 273 \\
\hline & Hypermarcas & Novo Mercado & Primária & 612 & 64 & 13.008 \\
\hline & $\underline{\text { Nutriplant }}$ & $\begin{array}{c}\text { BOVESPA } \\
\text { Mais }\end{array}$ & Primária & 21 & 0 & 2 \\
\hline \multirow{34}{*}{2007} & $\underline{\text { Tempo Part }}$ & Novo Mercado & Mista & 420 & 57 & 3.807 \\
\hline & MPX Energia & Novo Mercado & Primária & 2.035 & 58 & 164 \\
\hline & $\underline{\mathrm{BMF}}$ & Novo Mercado & Secundária & 5.984 & 70 & 255.001 \\
\hline & $\underline{\text { Panamericano }}$ & Nível 1 & Primária & 700 & 61 & 21.222 \\
\hline & Laep & BDR & Primária & 508 & 52 & 563 \\
\hline & Helbor & Novo Mercado & Primária & 252 & 60 & 723 \\
\hline & Amil & Novo Mercado & Mista & 1.401 & 69 & 4.398 \\
\hline & $\underline{\text { BR Brokers }}$ & Novo Mercado & Mista & 699 & 55 & 13 \\
\hline & Bovespa Hld & Novo Mercado & Secundária & 6.626 & 69 & 64.775 \\
\hline & Agrenco & BDR & Primária & 666 & 55 & 805 \\
\hline & Marisa & Novo Mercado & Primária & 506 & 67 & 13.177 \\
\hline & $\underline{\text { SEB }}$ & Nível 2 & Mista & 413 & 61 & 3.709 \\
\hline & Tenda & Novo Mercado & Primária & 603 & 60 & 10.172 \\
\hline & Trisul & Novo Mercado & Primária & 330 & 62 & 2.444 \\
\hline & $\underline{\text { BicBanco }}$ & Nível 1 & Mista & 822 & 62 & 5.197 \\
\hline & $\underline{\text { Sul America }}$ & Nível 2 & Primária & 775 & 67 & 19.261 \\
\hline & Satipel & Novo Mercado & Mista & 413 & 59 & 6.807 \\
\hline & CosanLtd $* *$ & BDR & Primária & 275 & 59 & 1.572 \\
\hline & $\underline{\text { EstacioPart }}$ & Nível 2 & Mista & 447 & 64 & 10.890 \\
\hline & Generalshopp & Novo Mercado & Primária & 287 & 59 & 4.999 \\
\hline & Multiplan & Nível 2 & Mista & 925 & 66 & 24.419 \\
\hline & Providencia & Novo Mercado & Primária & 469 & 64 & 11.135 \\
\hline & $\underline{\text { Springs }}$ & Novo Mercado & Mista & 656 & 69 & 7.383 \\
\hline & ABC Brasil & Nível 2 & Mista & 609 & 49 & 6.050 \\
\hline & $\underline{\text { Triunfo Part }}$ & Novo Mercado & Mista & 513 & 59 & 7.139 \\
\hline & $\underline{\text { Guarani }}$ & Novo Mercado & Primária & 666 & 63 & 12.388 \\
\hline & $\underline{\text { Kroton }}$ & Nível 2 & Mista & 479 & 60 & 11.297 \\
\hline & $\underline{\mathrm{MRV}}$ & Novo Mercado & Mista & 1.193 & 60 & 15.657 \\
\hline & Patagonia** & BDR & Mista & 76 & 56 & 2.846 \\
\hline & Minerva & Novo Mercado & Mista & 444 & 62 & 11.660 \\
\hline & InvestTur & Novo Mercado & Primária & 945 & 53 & 17 \\
\hline & Redecard & Novo Mercado & Mista & 4.643 & 67 & 29.766 \\
\hline & Indusval & Nivel1 & Mista & 253 & 59 & 290 \\
\hline & Tegma & Novo Mercado & Mista & 604 & 64 & 6.776 \\
\hline
\end{tabular}




\begin{tabular}{|c|c|c|c|c|c|c|}
\hline Ano & Empresa & $\begin{array}{l}\text { Segmento de } \\
\text { listagem }\end{array}$ & $\begin{array}{c}\text { Natureza da } \\
\text { oferta }\end{array}$ & $\begin{array}{l}\text { Volume R\$ } \\
\text { milhões }{ }^{1}\end{array}$ & $\begin{array}{c}\mathbf{N}^{0} \text { de } \\
\text { corretoras }^{2}\end{array}$ & $\begin{array}{c}\mathbf{N}^{\mathbf{0}} \text { de } \\
\text { investidores }\end{array}$ \\
\hline & Marfrig & Novo Mercado & Mista & 1.021 & 62 & 4.933 \\
\hline & Daycoval & Nível 1 & Mista & 1.092 & 62 & 7.585 \\
\hline & Cruzeiro Sul & Nível 1 & Mista & 574 & 61 & 4.221 \\
\hline & EZTec & Novo Mercado & Primária & 542 & 62 & 5.553 \\
\hline & $\underline{\log -I n}$ & Novo Mercado & Mista & 848 & 67 & 26.898 \\
\hline & $\underline{\text { SLC Agricola }}$ & Novo Mercado & Mista & 490 & 64 & 9.750 \\
\hline & $\underline{\text { Parana }}$ & Nível 1 & Primária & 529 & 50 & 8.586 \\
\hline & Inpar S/A & Novo Mercado & Primária & 756 & 60 & 9.614 \\
\hline & Tarpon & BDR & Primária & 444 & 56 & 10.714 \\
\hline & $\underline{\text { Sofisa }}$ & Nivel1 & Mista & 505 & 61 & 7.269 \\
\hline & Wilson Sons & BDR & Mista & 706 & 57 & 11.915 \\
\hline & $\underline{\text { Cremer }}$ & Novo Mercado & Mista & 552 & 58 & 9.419 \\
\hline & Agra Incorp & Novo Mercado & Mista & 786 & 62 & 5.375 \\
\hline & CR2 & Novo Mercado & Primária & 308 & 58 & 2.810 \\
\hline & Bematech & Novo Mercado & Mista & 407 & 60 & 8.718 \\
\hline & $\underline{\text { Metalfrio }}$ & Novo Mercado & Mista & 453 & 65 & 9.672 \\
\hline & JHSF Part & Novo Mercado & Primária & 432 & 66 & 4.561 \\
\hline & Fer Heringer & Novo Mercado & Mista & 350 & 64 & 9.275 \\
\hline & $\underline{\text { BR Malls Par }}$ & Novo Mercado & Primária & 657 & 66 & 13.909 \\
\hline & Even & Novo Mercado & Primária & 460 & 65 & 11.366 \\
\hline & Pine & Nivel1 & Mista & 517 & 55 & 20.251 \\
\hline & JBS & Novo Mercado & Mista & 1.617 & 61 & 22.984 \\
\hline & Anhanguera & Nível 2 & Mista & 512 & 60 & 13.742 \\
\hline & GVT Holding & Novo Mercado & Primária & 1.076 & 59 & 14.597 \\
\hline & Sao Martinho & Novo Mercado & Mista & 424 & 64 & 24.686 \\
\hline & Iguatemi & Novo Mercado & Primária & 549 & 64 & 16.889 \\
\hline & Tecnisa & Novo Mercado & Mista & 791 & 66 & 17.436 \\
\hline & $\underline{\mathrm{CC} \text { Des Imob }}$ & Novo Mercado & Mista & 522 & 63 & 22.294 \\
\hline & $\underline{\text { Rodobensimob }}$ & Novo Mercado & Primária & 449 & 62 & 14.181 \\
\hline & PDG Realt & Novo Mercado & Mista & 648 & 62 & 12.018 \\
\hline \multirow{8}{*}{2006} & Dufrybras & BDR & Secundária & 850 & 60 & 10.177 \\
\hline & Lopes Brasil & Novo Mercado & Secundária & 475 & 59 & 9.930 \\
\hline & $\underline{\text { Positivo Inf }}$ & Novo Mercado & Mista & 604 & 61 & 18.814 \\
\hline & Odontoprev & Novo Mercado & Mista & 522 & 55 & 8.860 \\
\hline & Ecodiesel & Novo Mercado & Primária & 379 & 58 & 9.446 \\
\hline & $\underline{\text { Terna Part }}$ & Nível 2 & Mista & 627 & 52 & 6.509 \\
\hline & $\underline{\text { Profarma }}$ & Novo Mercado & Mista & 401 & 53 & 4.609 \\
\hline & $\underline{\text { Brascan Res }}$ & Novo Mercado & Mista & 1.188 & 54 & 4.319 \\
\hline
\end{tabular}




\begin{tabular}{|c|c|c|c|c|c|c|}
\hline Ano & Empresa & $\begin{array}{l}\text { Segmento de } \\
\text { listagem }\end{array}$ & $\begin{array}{c}\text { Natureza da } \\
\text { oferta }\end{array}$ & $\begin{array}{l}\text { Volume } \mathbf{R} \$ \\
\text { milhões }\end{array}$ & $\begin{array}{c}\mathbf{N}^{\mathbf{0}} \mathrm{de} \\
\text { corretoras }^{2}\end{array}$ & $\begin{array}{c}\mathbf{N}^{0} \text { de } \\
\text { investidores }\end{array}$ \\
\hline & M.Diasbranco & Novo Mercado & Secundária & 411 & 56 & 3.460 \\
\hline & $\underline{\text { Santos Bras }}$ & Nível 2 & Mista & 933 & 54 & 4.209 \\
\hline & Klabinsegall & Novo Mercado & Mista & 527 & 53 & 4.720 \\
\hline & Medial Saude & Novo Mercado & Mista & 742 & 53 & 3.131 \\
\hline & Abyara & Novo Mercado & Primária & 164 & 41 & 6 \\
\hline & MMX Miner & Novo Mercado & Primária & 1.119 & 35 & 18 \\
\hline & Datasul & Novo Mercado & Mista & 317 & 52 & 5.514 \\
\hline & GP Invest** & BDR & Primária & 706 & 49 & 2.373 \\
\hline & Lupatech & Novo Mercado & Mista & 453 & 55 & 11.453 \\
\hline & BrasilAgro & Novo Mercado & Primária & 583 & 35 & 3 \\
\hline & CSU CardSyst & Novo Mercado & Mista & 341 & 57 & 14.637 \\
\hline & ABnote & Novo Mercado & Secundária & 480 & 55 & 15.453 \\
\hline & Equatorial & Nível 2 & Mista & 540 & 56 & 7.521 \\
\hline & $\underline{\text { Totvs }}$ & Novo Mercado & Mista & 460 & 57 & 16.322 \\
\hline & Company & Novo Mercado & Mista & 282 & 55 & 13.166 \\
\hline & Gafisa & Novo Mercado & Mista & 927 & 57 & 14.028 \\
\hline & Copasa & Novo Mercado & Primária & 813 & 60 & 15.802 \\
\hline & $\underline{\text { Vivax }}$ & Nível 2 & Mista & 529 & 50 & 7.916 \\
\hline \multirow{9}{*}{2005} & $\underline{\mathrm{UOL}}$ & Nível 2 & Mista & 625 & 56 & 13.234 \\
\hline & Cosan & Novo Mercado & Primária & 886 & 52 & 9.079 \\
\hline & Nossa Caixa & Novo Mercado & Secundária & 954 & 54 & 7.666 \\
\hline & OHL Brasil & Novo Mercado & Mista & 496 & 42 & 1.084 \\
\hline & Energias BR & Novo Mercado & Mista & 1.185 & 44 & 468 \\
\hline & TAM S/A & Nível 2 & Mista & 548 & 48 & 1.212 \\
\hline & Localiza & Novo Mercado & Secundária & 265 & 48 & 809 \\
\hline & Submarino & Novo Mercado & Mista & 473 & 52 & 4.022 \\
\hline & $\underline{\text { Renar }}$ & Novo Mercado & Primária & 16 & 42 & 1.698 \\
\hline \multirow{7}{*}{2004} & Porto Seguro & Novo Mercado & Mista & 377 & 51 & 5.919 \\
\hline & DASA & Novo Mercado & Mista & 437 & 44 & 2.892 \\
\hline & Grendene & Novo Mercado & Secundária & 617 & 56 & 7.905 \\
\hline & CPFL Energia & Novo Mercado & Mista & 821 & 47 & 2.750 \\
\hline & ALL AmerLat & Nível 2 & Mista & 588 & 33 & 3.425 \\
\hline & Gol & Nível 2 & Mista & 878 & 40 & 11.397 \\
\hline & Natura & Novo Mercado & Secundária & 768 & 32 & 4.445 \\
\hline
\end{tabular}

* Dados Preliminares** Dados referentes somente à ("Oferta Brasileira").1. Volume financeiro total da operação2. Número de corretoras que participaram do consórcio de distribuição3. Número de investidores participantes do varejo (pessoas físicas + clubes de investimento) 


\section{APÊNDICE}

Apêndice 1 - Questionário aplicado aos professores de contabilidade 

Apêndice 1 - Questionário aplicado a professores de contabilidade

Deseja receber copla dos resultados da pesquisa?

CIM

อ Nב̃O

PERFIL : Profeseor(a) de contabilldade?

SIM

อ NÅO

PERFIL: Unidade da Federaçao na qual leclona:

\section{PERGUNTAS}

Lembre-6e de selecionar apenas uma resposta em cada questä́.

1. O valor do Patrimónlo Liquido (PL) de uma empresa e informaça Importante para os usuarlos da contabllidade.

\begin{tabular}{lllllllll}
1 & 2 & 3 & 4 & 5 & 6 & 7 & 8 & 9 \\
\hline & 0 & 0 & 0 & 0 & 0 & $\ominus$ & 0 & 0
\end{tabular}

2. A composiçâo do PL $\theta$ Informaçà Importante para os usuarios da Informaçăo contabll.

\begin{tabular}{lllllllll}
1 & 2 & 3 & 4 & 5 & 6 & 7 & 8 & 9 \\
\hline & 0 & 0 & 0 & $\ominus$ & $\ominus$ & $\ominus$ & $\ominus$ & 0
\end{tabular}

3. As alteraç0es provocadas no PL das empresas pelos pronunclamentos do CPC - Comite de Pronunciamentos Contabels afetaram algnificativamente o valor total deses grupo.

\begin{tabular}{lllllllll}
1 & 2 & 3 & 4 & 5 & 6 & 7 & 8 & 9 \\
\hline & 0 & 0 & 0 & 0 & 0 & 0 & 0 & 0 \\
\hline
\end{tabular}

4. As alteraç0̄es provocadas no PL das empresas pelos pronunclamentos do CPC afetaram de forma homogenea empresas de setores dlsitintos.

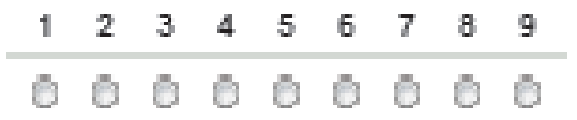

5. As alteraçoes provocadas no PL das empresas pelos pronunclamentos do CPC dificultaram a comparabillidade entre demonstraçoes contabels da proprla empresa elaboradas antes $\theta$ apos tals alteraçoes. 
200413 Quebsonkro- Fusquat Acederica

$\begin{array}{lllllllll}\mathbf{1} & \mathbf{2} & \mathbf{3} & \mathbf{4} & \mathbf{5} & \mathbf{6} & \mathbf{7} & \mathbf{8} & \mathbf{9} \\ 0 & 0 & 0 & 0 & 0 & 0 & 0 & 0 & 0\end{array}$

6. As alteraçðes Introduzldas no PL pelos pronunclamentos do CPC diflicultaram a comparablildade entre demonstraçøes contabels de empresas pertencentes a æegmentos distintos.

$\begin{array}{lllllllll}1 & 2 & 3 & 4 & 5 & 6 & 7 & 8 & 9\end{array}$

000000

7. Conhecer a composiça do PL $\theta$ nâo somente seu valor total $9 \theta$ tornou mals Importante apos as alteraç0es Introduzidas pelos pronunclamentos do CPC.

$\begin{array}{lllllllll}1 & 2 & 3 & 4 & 5 & 6 & 7 & 8 & 9 \\ 0 & 0 & 0 & 0 & 0 & 0 & 0 & 0 & 0\end{array}$

8. Considero Importante tranঞmitir aos alunos conheclmentos relacionados a composiçăo do PL $\theta$ como tal composiçào pode afetar a utllizaçăo das Informaçøes contabels.

$\begin{array}{lllllllll}1 & 2 & 3 & 4 & 5 & 6 & 7 & 8 & 9\end{array}$

6 000000

Envar

Tecnologla Geogle Doc5

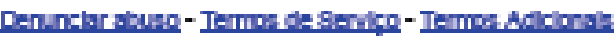

Disponibilizado em https://docs.google.com/spreadsheet/viewform?formkey=dDgxY0QwR2dTMG5SUi1zNGo1cE0xSmc6MQ\#gid=0 para respostas online. 